\title{
A Souvenir from the North: Images, Narratives, and Power in the Athabasca-Mackenzie River Basin, 1882-1914
}

by

Matt Dyce B.A. (Hons)

\author{
A thesis submitted to \\ the Faculty of Graduate Studies and Research \\ in partial fulfilment of \\ the requirements for the degree of \\ Master of Arts \\ Department of History \\ Carleton University \\ Ottawa, Ontario, Canada \\ August 2, 2006 \\ (C) 2006 Matt Dyce
}




$\begin{array}{ll}\begin{array}{l}\text { Library and } \\ \text { Archives Canada }\end{array} & \begin{array}{l}\text { Bibliothèque et } \\ \text { Archives Canada }\end{array} \\ \begin{array}{l}\text { Published Heritage } \\ \text { Branch }\end{array} & \begin{array}{l}\text { Direction du } \\ \text { Patrimoine de l'édition }\end{array} \\ \begin{array}{l}\text { 395 Wellington Street } \\ \text { Ottawa ON K1A 0N4 }\end{array} & \begin{array}{l}\text { 395, rue Wellington } \\ \text { Ottana ON K1A ON4 } \\ \text { Canada Oa }\end{array}\end{array}$

Your file Votre référence ISBN: 978-0-494-18259-8 Our file Notre référence ISBN: 978-0-494-18259-8

NOTICE:

The author has granted a nonexclusive license allowing Library and Archives Canada to reproduce, publish, archive, preserve, conserve, communicate to the public by telecommunication or on the Internet, loan, distribute and sell theses worldwide, for commercial or noncommercial purposes, in microform, paper, electronic and/or any other formats.

The author retains copyright ownership and moral rights in this thesis. Neither the thesis nor substantial extracts from it may be printed or otherwise reproduced without the author's permission.
AVIS:

L'auteur a accordé une licence non exclusive permettant à la Bibliothèque et Archives Canada de reproduire, publier, archiver, sauvegarder, conserver, transmettre au public par télécommunication ou par l'Internet, prêter, distribuer et vendre des thèses partout dans le monde, à des fins commerciales ou autres, sur support microforme, papier, électronique et/ou autres formats.

L'auteur conserve la propriété du droit d'auteur et des droits moraux qui protège cette thèse. $\mathrm{Ni}$ la thèse ni des extraits substantiels de celle-ci ne doivent être imprimés ou autrement reproduits sans son autorisation.
In compliance with the Canadian

Privacy Act some supporting forms may have been removed from this thesis.

While these forms may be included in the document page count, their removal does not represent any loss of content from the thesis.
Conformément à la loi canadienne sur la protection de la vie privée, quelques formulaires secondaires ont été enlevés de cette thèse.

Bien que ces formulaires aient inclus dans la pagination, il n'y aura aucun contenu manquant. 


\begin{abstract}
The arrival of photography in Canada during the mid nineteenth century parallels the emergence of a conceptual backdrop: 'modernity,' which many historians have employed in explaining major changes occurring then in Western culture and society. As photography's unchallenged ability to convey reality altered visual culture and modernized 'ways of seeing,' developments in Canada revolved around this new and unfolding power of representation. Representation holds that the objective truth of an image will always be hidden behind what the photographer intended and also includes the theoretical framework within which an image may be read or 'decoded' by a viewer. In examining the cultural and historical currency possessed by visual reproductions, this study will show how cultural meaning is derived, negotiated and reciprocated through the outcomes and uses of photographic production and reproduction.

The purpose of this thesis is to identify, question and analyze photographic practice and representation in the river system comprising the 'Far North' part of the North-West Territories. I examine the period from 1882 to 1914. These dates respectively mark the points when the first mechanically reproduced images were created of the Athabasca-Mackenzie drainage basin, and when the commercial photographs made of that river system by C.W. Mathers reached their recirculatory zenith.

C.W. Mathers created a set of commercial photographs of the Far North in 1901, and the series is placed at the centre of this study. In suggesting his images were 'recirculating,' I not only mean that more of Mathers' photographs were in material circulation than at any other time, but that the power-knowledge complexes coupled with his images reached a zenith as well. I ask how Mathers' images can explain the confluence of colonialism, modernity and photography in the North, employing an analysis of geographical imaginations of time and space scholars have conceptualized as a metropolitan(city)-frontier(hinterland) relationship.
\end{abstract}




\section{Acknowledgments}

Academics certainly like to thank people, and if writing an M.A. thesis serves as a good introduction to academia, it is easy to see why.

Part of this thesis has to be dedicated to the many unfortunate treeplanters who, lost on some unknown mountainside, have sat through the long answer to "what do you study in school, anyway?" over the years. Friends rarely make this same mistake, and I know Mike Lawson, Anne Baldwin, Jono Aitchison, and Luke Allen have been particularly good friends because they keep asking. 'My family's support has only grown since they realized I had no plans to ever leave university. Above all, Daniella Balabuk helped me write this more than she will ever believe.

It is a well-concealed fact that Carleton's Department of History has the best graduate offices on campus. It is therefore uncanny that we also have the best graduate secretary, Joan White. Bruce Elliott and Joanna Dean have also been supportive and encouraging faculty members. Fellow M.A. students Steve Irving and Allison McDonald made graduate life bearable at Carleton whether engaging the mundane, 'raising the level of discourse,' or simply working to keep things weird. One day this project will return home to Trent University, but until that time I will aspire to retread the candour and wisdom shown to me there by Carolyn Kay, Alison Falby, Keith Walden, and especially John Wadland.

Joan Schwartz will always be an inspiration as a scholar, and has provided many helpful comments, constructive criticisms, and a very thorough edit of this thesis. The remaining mistakes and errors are unequivocally mine alone.

I also wish to thank Marcus Schubert and Edward Burtynsky for permission to reproduce from the 'Oil Fields' series.

There are a few important others who mix in the ether between friend, professor, and something else; they have greatly influenced my thinking and deserve to be acknowledged here. The following pages would be incredibly boring without the help of John C. Walsh the arch-Foucauldian, the spirit of '76 microfiche reader in the MacOdrum Library basement, and of course my dog, Kaiser.

My supervisor stands apart from this long list with good reason. James Opp was not officially signed to this project until the end of first year, yet has without a doubt been guiding me in life and mind since the very first day I set foot on campus. With my deepest respect and sincerest admiration: thank-you. 


\section{Table of Contents}

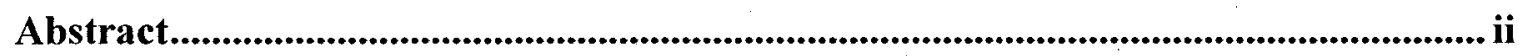

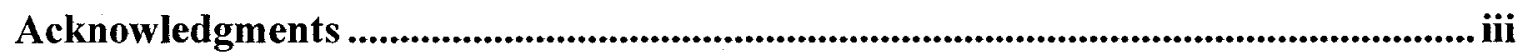

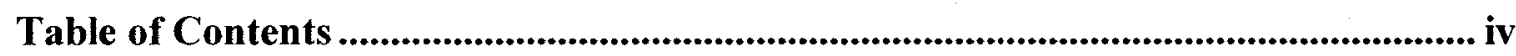

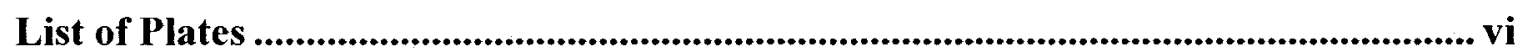

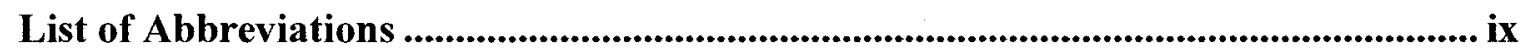

\section{Chapter 1: Introduction}

"The Twentieth Century is Canada's" .................................................................... 1

\section{Chapter 2: The Geological Survey of Canada, 1882-1890}

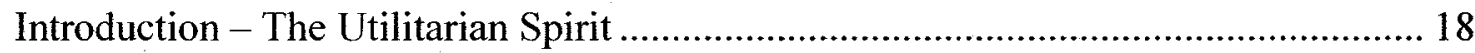

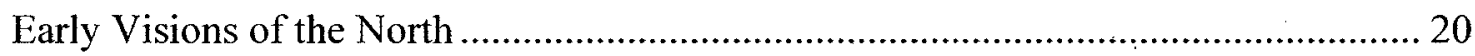

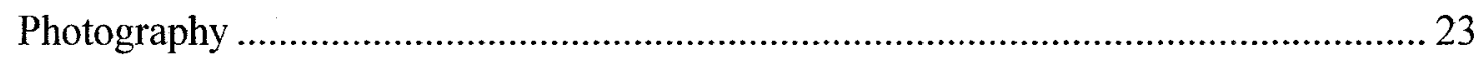

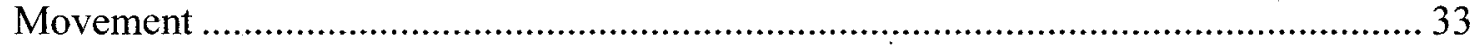

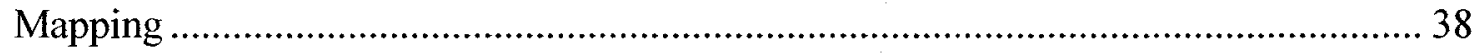

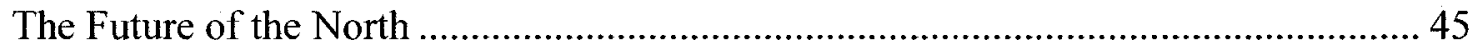

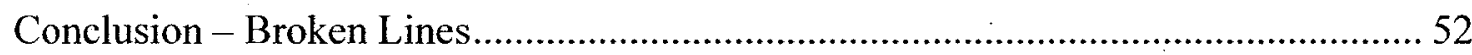

\section{Chapter 3: Illustrated Adventure Stories, 1890-1900}

Introduction - The Barren Lands of the Far North .............................................. 55

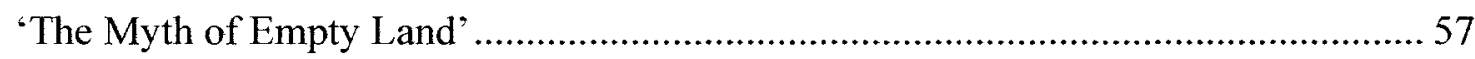

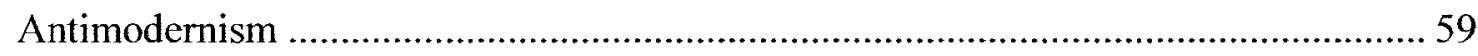

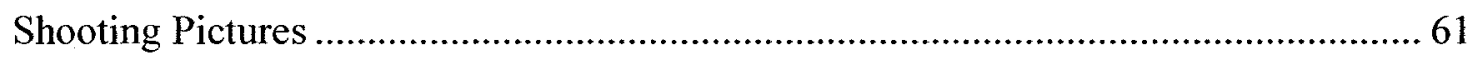

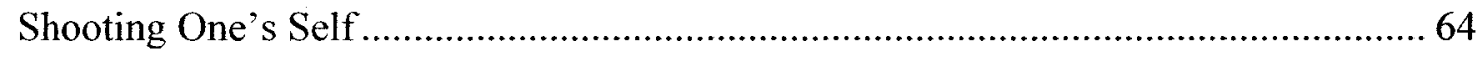

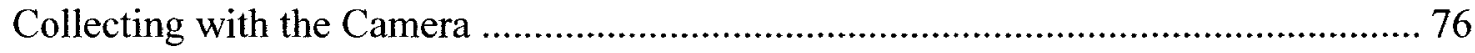

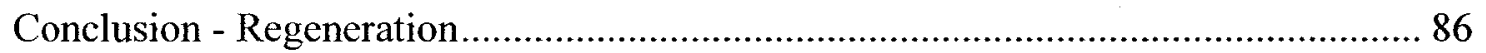


Chapter 4: C.W. Mathers' Visions, 1901

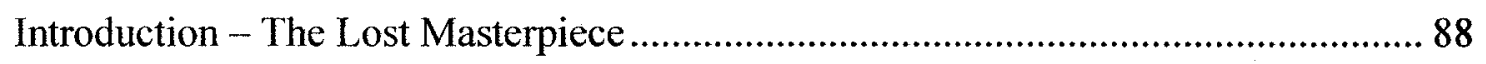

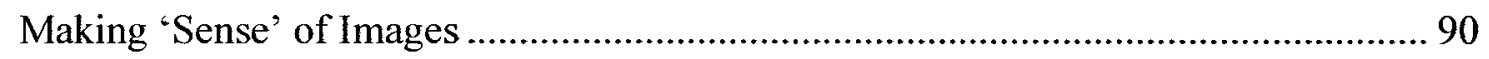

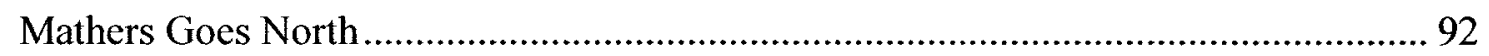

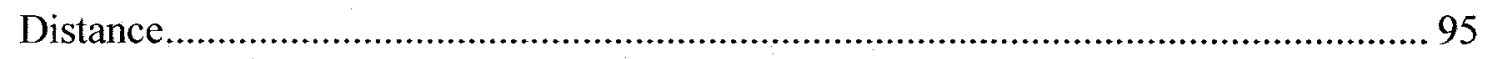

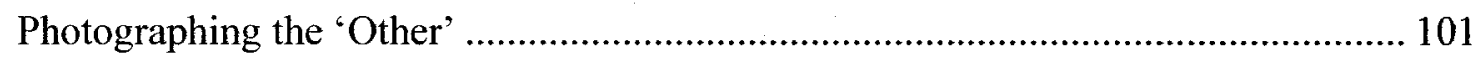

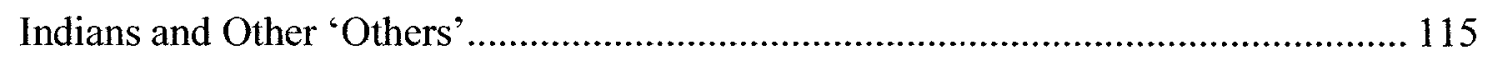

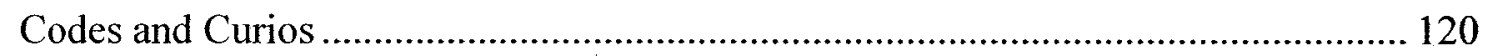

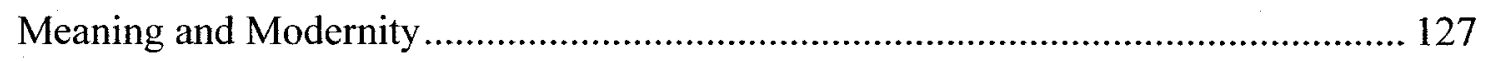

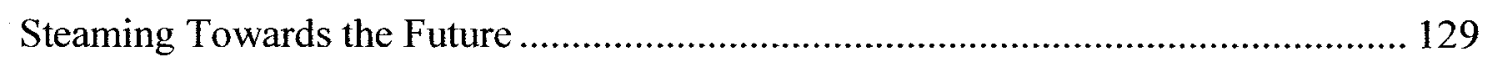

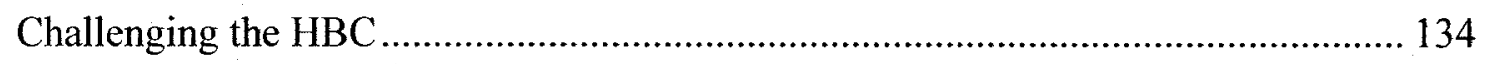

Conclusion - C.W. Mathers' Northern Vision .................................................. 140

\section{Chapter 5: Recirculation to 1914}

Introduction - MacFarlane's Paper, Mathers' Photographs .................................... 143

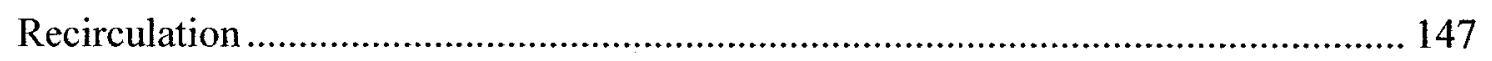

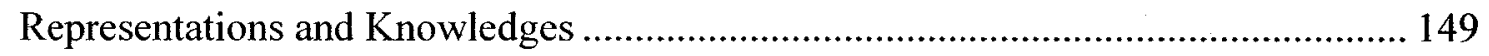

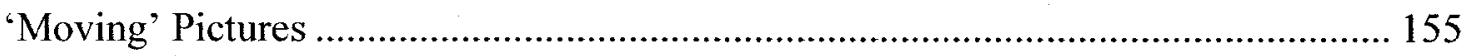

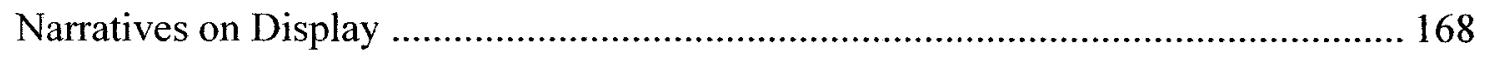

Conclusion - C.W. Mathers' Photographs are History ....................................... 171

\section{Chapter 6: Conclusion}

Images, Narratives, and Power .................................................................. 183

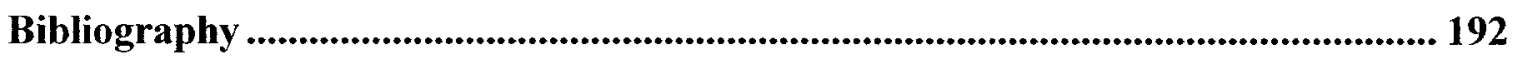




\section{List of Plates}

Plate 1: $\quad$ Shooting the Rapids of the Slave River ...................................................

Plate 2: [A page from] "The Twentieth Century is Canada's" ...................................4

Plate 3: The Creighton Nickel-Copper Mine near Copper Cliff, Ontario.....................6

Plate 4: $\quad$ A Monarch without a Kingdom [and] A Buffalo Cemetery .........................12

Plate 5: "The Deserted Village" - The Indians' Winter Home..................................13

Plate 6: Electric Light Station, Fort Simpson, Mackenzie River .............................15

Plate 7: Grand Rapids, Athabasca River, Looking Southward or Up Stream. ..........22

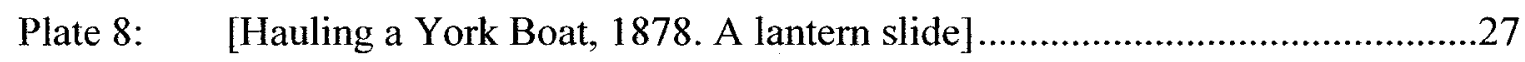

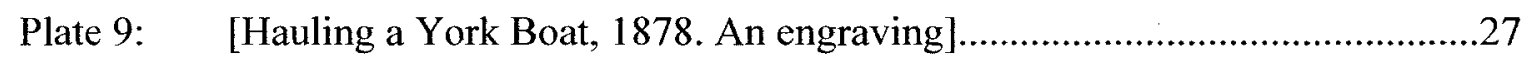

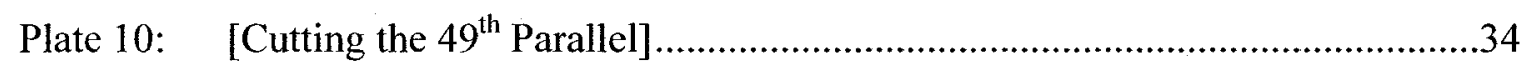

Plate 11: Map Shewing the General Northern Limits of the Principle Forest Trees of the Dominion of Canada [the quarter-section shown here contains the disputed area and a large portion of the sub-Arctic North] ......44

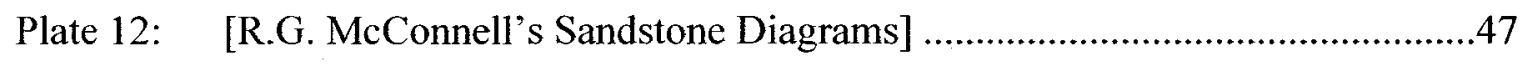

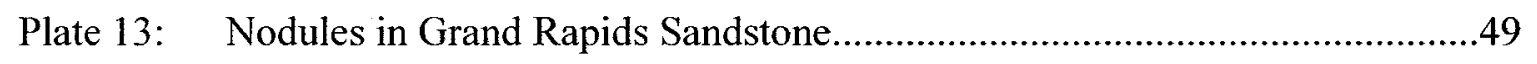

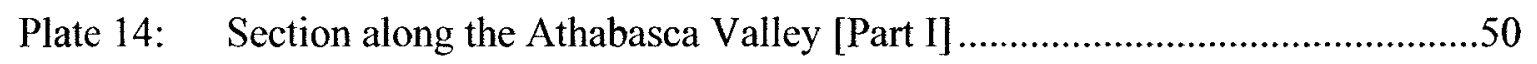

Plate 15: Section along the Athabasca Valley [Part II] .........................................51

Plate 16: Dominion of Canada Outline Map Showing the Larger Unexplored

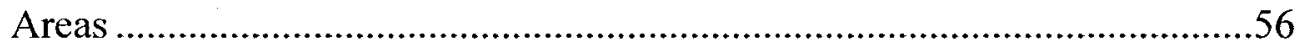

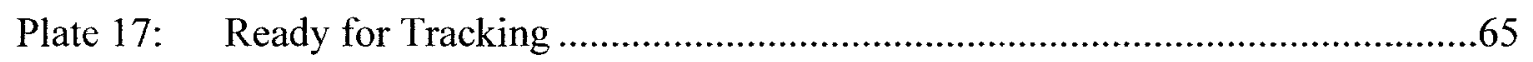

Plate 18: An Old Indian Deserted by His People ....................................................69

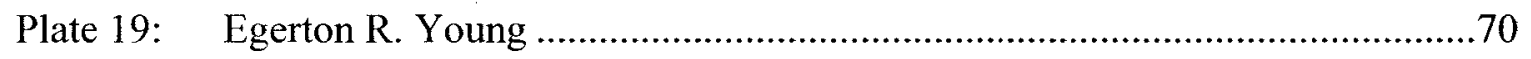

Plate 20: "We exchanged our black clothes for our leather suits" $\quad$ ".........................70 
Plate 21: I. - Nothing but the hind quarter of a wild cat for breakfast, off looking for game. [and] II. - Six hundred yards is a long shot, but wild cat is poor food, and so we will try for something better.

Plate 22: III. - Come, share with me our savory venison ......................................73

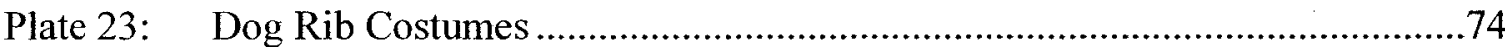

Plate 24: $\quad$ Eskimo Crania obtained with Broca's gauging instruments and No. 8

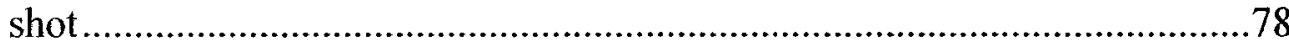

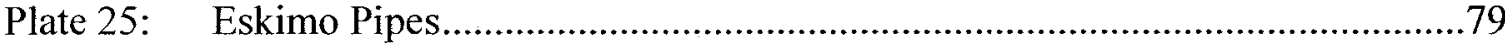

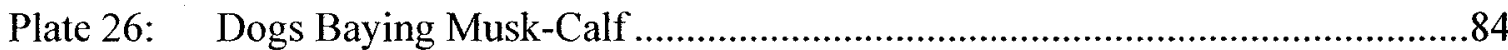

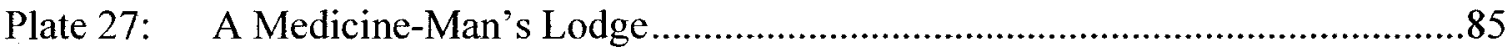

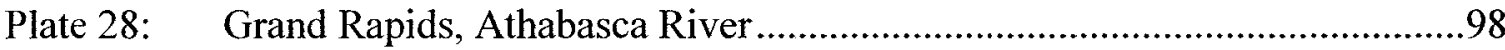

Plate 29: $\quad$ Portrait of Sarcee Indian Assinatappi and His Wife ..................................104

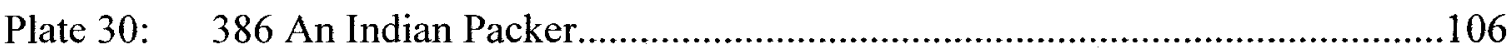

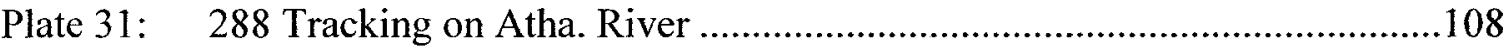

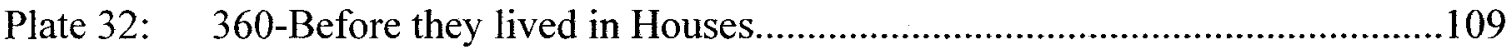

Plate 33: $\quad 314$ - Great Slave Lake from Fort Resolution [Detail]..............................114

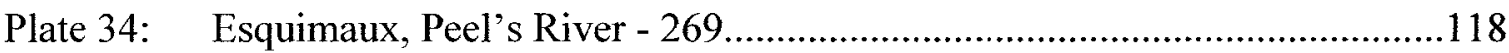

Plate 35: $\quad 363-$ Poverty Great Slave Lake ...............................................................119

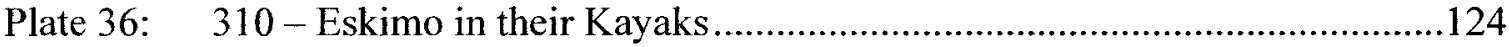

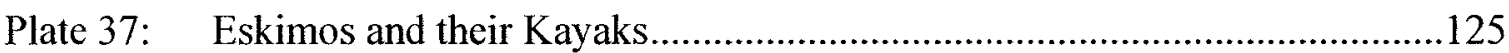

Plate 38: The H.B. Co's Steamer (Wrigley) at Fort Simpson ..................................132

Plate 39: The Crew of the H.B.Co's S.S. Wrigley taking a moose on board. ............133

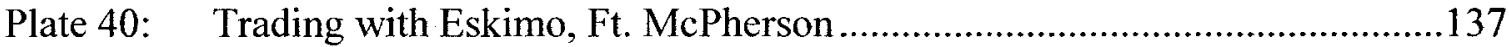

Plate 41: Indians Packing across the Island in Grand Rapids ..............................138 
Plate 42: Shewing Progress of Field Operations by Geological Survey, $1843-$ 1903.

Plate 43: We Tell the Tale of a Whale .151

Plate 44: Mr. Stefansson [and] Esquimaux in their Kayaks .159

Plate 45: Harvard Man, on His Way North, Shot Rapids in a 50-Foot Scow. .160

Plate 46: Bishop Reeve, Stefansson and Resident Clergyman at Simpson .161

Plate 47: Anatomy of Recirculation I - Mathers and Stewart .165

Plate 48: Anatomy of Recirculation II -- Mathers, Stewart and Cameron . 166

Plate 49: Rapids on the Slave River at the Second Portage. .173

Plate 50: $\quad$ Starting up the Athabasca .174

Plate 51: "Tepees dotted the valley." 177

Plate 52: M251 Cree Indians. 178

Plate 53: $\quad$ Oil Fields No. 24 .191 


\section{List of Abbreviations}

$\begin{array}{ll}\text { (CNR) } & \text { Canadian National Railways } \\ \text { (CPR) } & \text { Canadian Pacific Railway } \\ \text { (GSC) } & \text { Geological Survey of Canada } \\ \text { (HBC) } & \text { Hudson's Bay Company } \\ \text { (LAC) } & \text { Library and Archives of Canada } \\ \text { (PAA) } & \text { Provincial Archives of Alberta } \\ \text { (RNWMP) } & \text { Royal North-West Mounted Police }\end{array}$




\section{Chapter 1: Introduction}

\section{"The Twentieth Century is Canada's"}

Sir Wilfrid Laurier's 1904 proclamation that the 'twentieth century belongs to Canada' had a profound affect on Agnes Christina Laut. ${ }^{1}$ Canada at last seemed to be fulfilling the great promises of a new empire dreamed of by expansionists throughout the latter half of the nineteenth century: the economy was booming, the new provinces of Alberta and Saskatchewan completed the transcontinental nation, settlement in the Northwest was occurring at an unprecedented level, and new technologies in transportation and communication made the great distances that separated the major cities appear smaller and smaller. These developments in industry and agriculture seemed to be putting nature firmly in place at the service of humanity. Canada, as evidenced by the Northwest, was becoming modern.

In 1907, Agnes Laut, journalist, author, and accomplished historian, published a magazine article echoing the enthusiasm of the Prime Minister's decree. ${ }^{2}$ The paper was subtitled, as she saw it, "A Romantic Story of a People Just Discovering Their Own Country," and the piece certainly lived up to its aspirations. To Laut, nothing seemed more romantic about Canada than the exploits and adventures of the heroic voyageurs who challenged the wild and dangerous nature of Rupert's Land in search of fur and other riches. Accordingly, readers of Laut's article were treated to a dramatic scene from

\footnotetext{
${ }^{1}$ An army of antiquarians has pointed out that the famous quote Laurier gave to the Ottawa Canadian Club was accurately, "The nineteenth century was the century of the United States, I think that we can claim that it is Canada that shall fill the twentieth century."

${ }^{2}$ Laut was already famous for taking the renowned American historian Francis Parkman to task for overlooking what she was able to prove in 1904. She showed that it was the French-Canadians, Radisson and Groseillers, who had 'discovered the great Northwest.' This took the credit from Marquette, Joliet, and La Salle, the explorers Parkman assosciated with heroically drawing the region that would eventually become America. Agnes C. Laut, Pathfinders of the West: Being the Thrilling Story of the Adventures of the Men Who Discovered the Great Northwest (New York: The MacMillan Company, 1904), ix-xvii.
} 
the North-West Territories: a photograph showing a fur trader's scow cresting a dangerously steep falls on the Slave River. [Plate 1]

Laut was not far from the circles of academic history. She was a friend and colleague of Lawrence J. Burpee, a young social scientist who would go on to become the founding president of the Canadian Historical Association in 1922. She admired Burpee for his belief that Canadian history should be engaging and exciting, and the two shared a linear thinking in their progressive vision of the nation's past. Unlike many academic historians interested in dry and exhaustive stories of the Dominion's political maturation, Burpee and Laut believed that the sweeping sagas of the great fur companies in the Northwest were the real 'heralds of empire."3

Her article was published in the American magazine, World's Work, a 'belles lettres' periodical aimed and addressed toward wealthy 'capitalists' along the Eastern seaboard. According to Laut, "the swift progress of the United States meant exhaustion of natural resources, and the moment that point was reached the tide of development would turn to Canada." ${ }^{4}$ Nothing seemed to illustrate that this tipping point had been reached better than the photographs of C.W. Mathers. His images, which Laut acquired for her triumphal essay, loomed in full-page spreads depicting Rocky Mountain vistas and great prairie wheat harvests. Additional photographs, created in the North-West Territories at the turn of the twentieth century, dominate and enclose Laut's textual

\footnotetext{
3 'Heralds of Empire' was the title of one of Laut's first books. A sampling of her collected works is all that is needed to form an impression of her vision of Canadian history. Agnes C. Laut, Heralds of Empire; Being the Story of One Ramsay Stanhope (Toronto W. Briggs, 1902), i.

${ }^{4}$ Agnes C. Laut, "The Twentieth Century Is Canada's: The Romantic Story of a People Just Discovering Their Own Country," World's Work 15 (1907): 8507.
} 


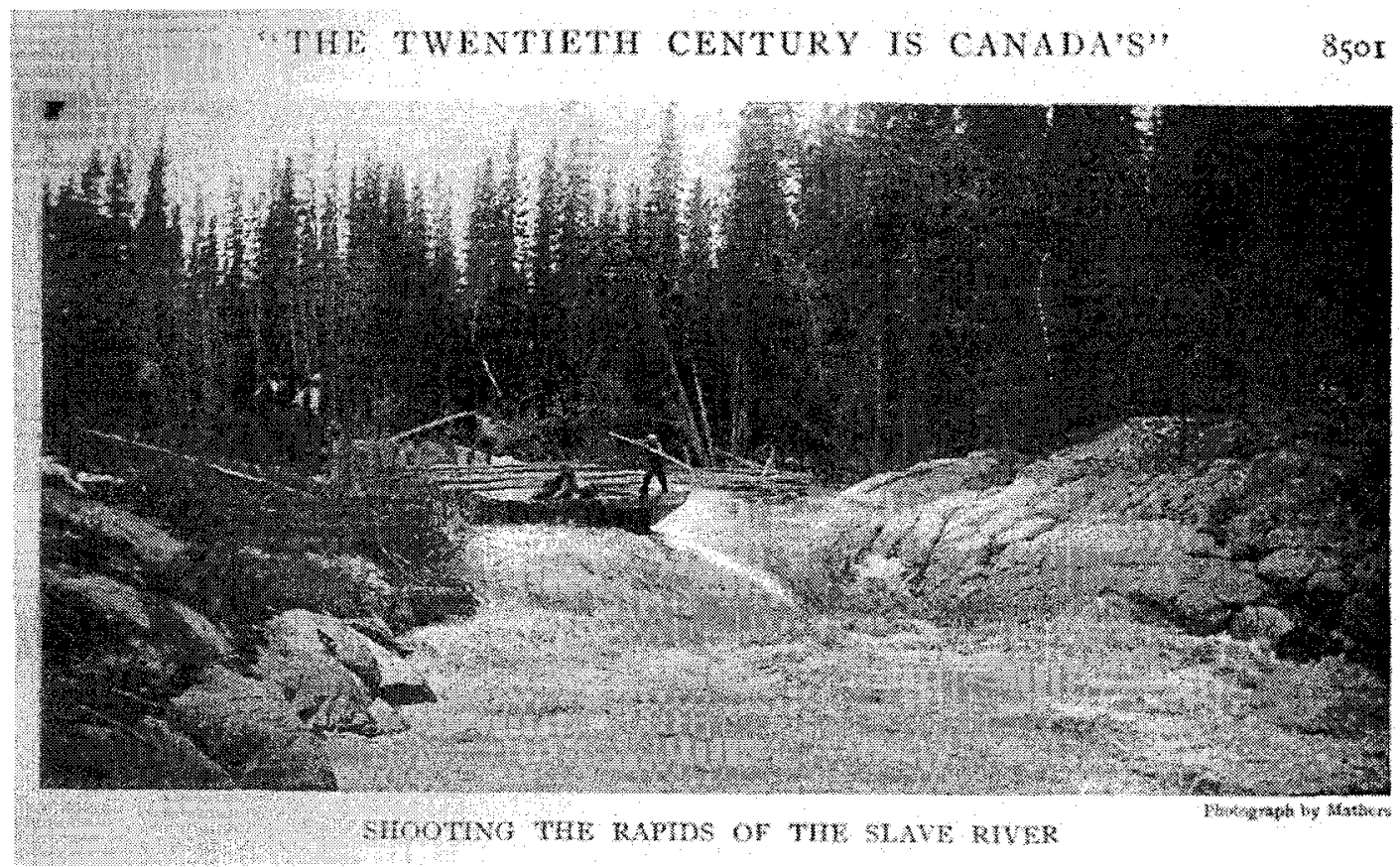

\section{Plate 1: Shooting the Rapids of the Slave River}

Source: Agnes C. Laut, "The Twentieth Century Is Canada's: The Romantic Story of a People Just Discovering Their Own Country," World's Work 15 (1907): 8501 . 


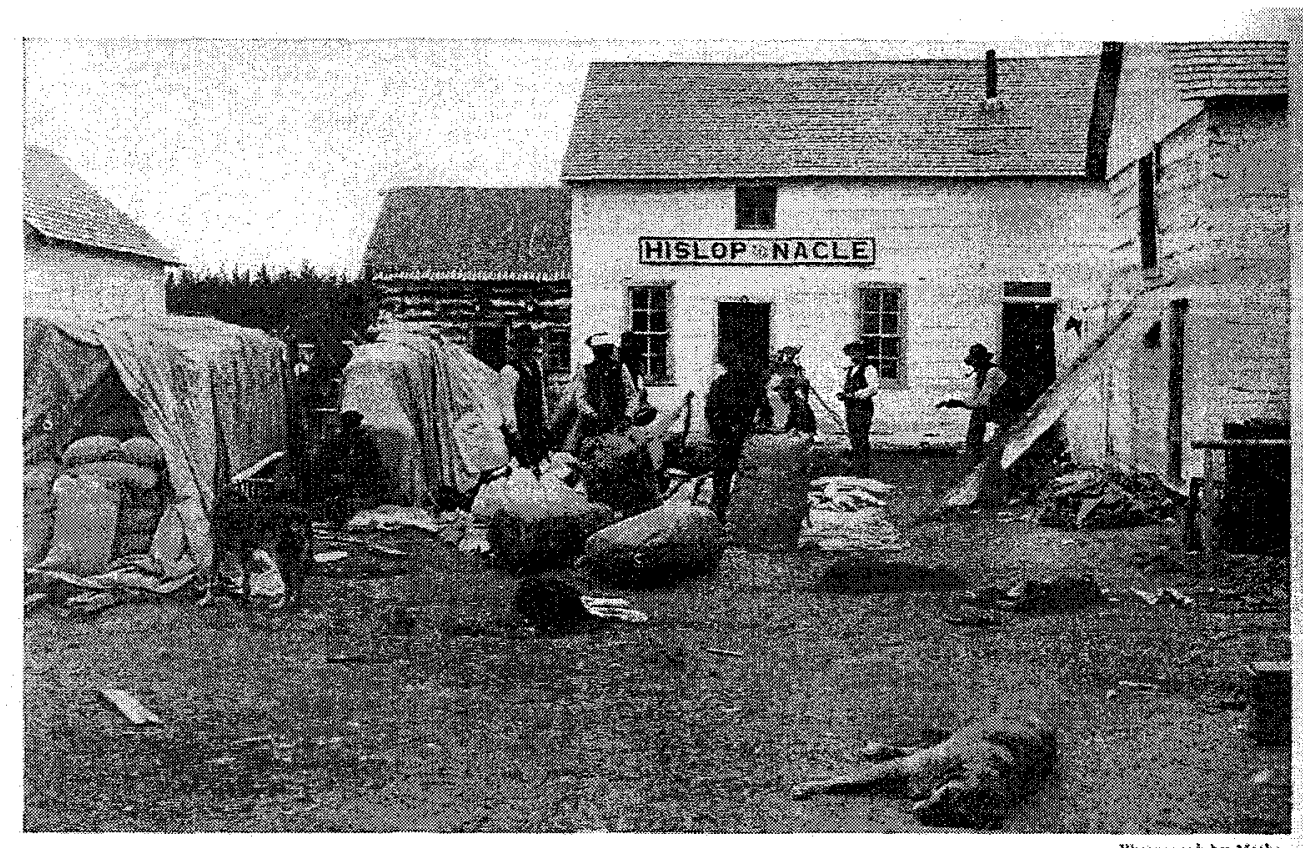

OXE OF CVILIZATION'S OUTPOSTS

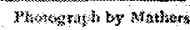

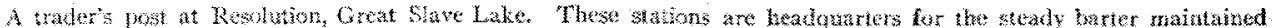

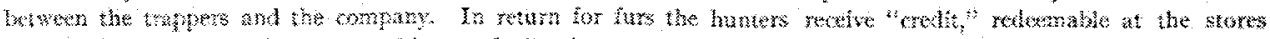

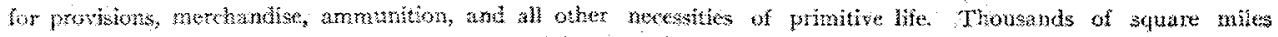
are served by one of the "factories"

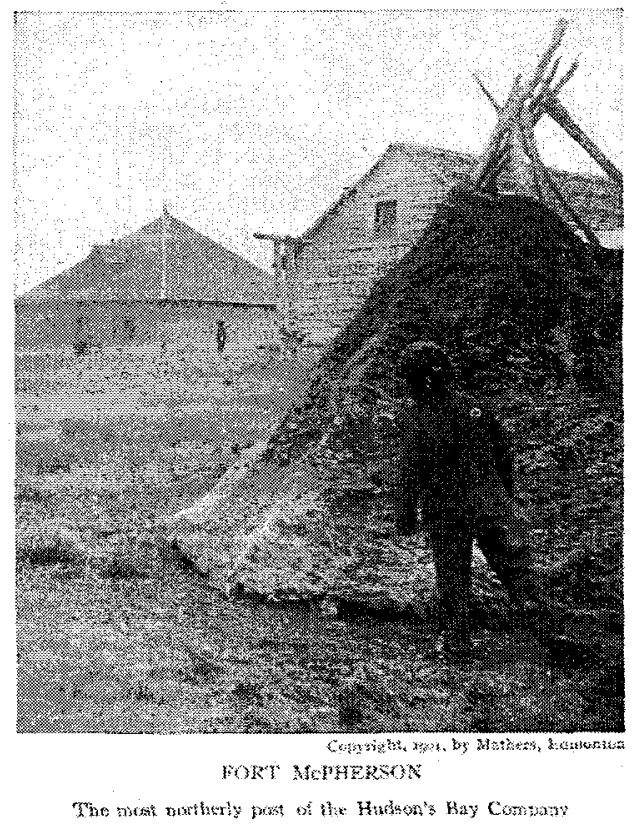

ing. Here was the stuft Could a market be found of be created for it?

It used to be a stock apology for hard times in Canatat that a couniry with a big neighbor next door was bound to be dwarted incturtally. It never seemed to dawn on the apologists-and I am soxy to say that half the papes that are now shouting in Canada were" "calamity. howlers" in the hare doye that the swift progress of the United States mont exhaustion of natural resources, and the moment that point was reached the tide of develowment would turn to Canada. According to Mr. Hill, the point of exhaustion south of the boudary has aheady been approacher. At all events, of the lide luming to Canada, so per cent of the inpouring population and 80 per cent. of the in pouring captal are from the United States. The presence of the big neighbre is helping formard rather than dwating the Dominion.

$$
\text { AREA AND POPULATON }
$$

When one surveys Canada, the facts are so big as to be bewildering.

In the first place, the area of the Dominion

\section{Plate 2: [A page from] "The Twentieth Century is Canada's"}

Source: Agnes C. Laut, "The Twentieth Century Is Canada's: The Romantic Story of a People Just Discovering Their Own Country," World's Work 15 (1907): 8516. 
points with their sheer visual mass, echoing "As Laurier says - the twentieth century belongs to Canada, industrially, at least." ${ }^{\circ 5}$ [Plate 2]

The photographs provided a story of adventure in the North of Canada, serendipitously culminating in the advent of capitalism beyond the edges of civilization. To Laut, this meant Canada was ready for development. Citing the recent Ontario booms in cobalt and iron she tempted American investors by suggesting that "only one-tenth of Canada's mineral regions have yet been explored. All Labrador, all Keewatin, all Mackenzie River, the most of the Peace River and Athabasca, nine-tenths of British Columbia, and the Yukon are still a terra incognita for the prospector. What these unknown mineralized regions may yield may only be inferred from discoveries daily being made. ${ }^{.6}$ To impress her point a photograph was supplied by the Mines Branch of the Department of the Interior. [Plate 3] Cutting through the rolling snow-covered hills and picturesque windrows of spruce and ash, the machinery of state reaches deep to draw upon the dark wealth of the earth. As Laut claimed, "A nation can prosper as it trades what it draws from the soil."

The powerful way that photographs communicated the readiness of Canadian modernity was not a providential or natural occurrence, nor was it a construction of solely human design. To return to the site of Mathers' photographs - the AthabascaMackenzie river network extending from Edmonton to the Arctic Sea - means understanding the relationship between photography and the land, and calls the reader to look beyond the simple unilateral intent of word and image. That images of the 'Far North,' could speak for Canada and progress was not an uncontested assumption, while

\footnotetext{
${ }^{5}$ Laut, "The Twentieth Century Is Canada's," 8516.

${ }^{6}$ Laut, "The Twentieth Century Is Canada's," 8515.

${ }^{7}$ Laut, "The Twentieth Century Is Canada's," 8503.
} 


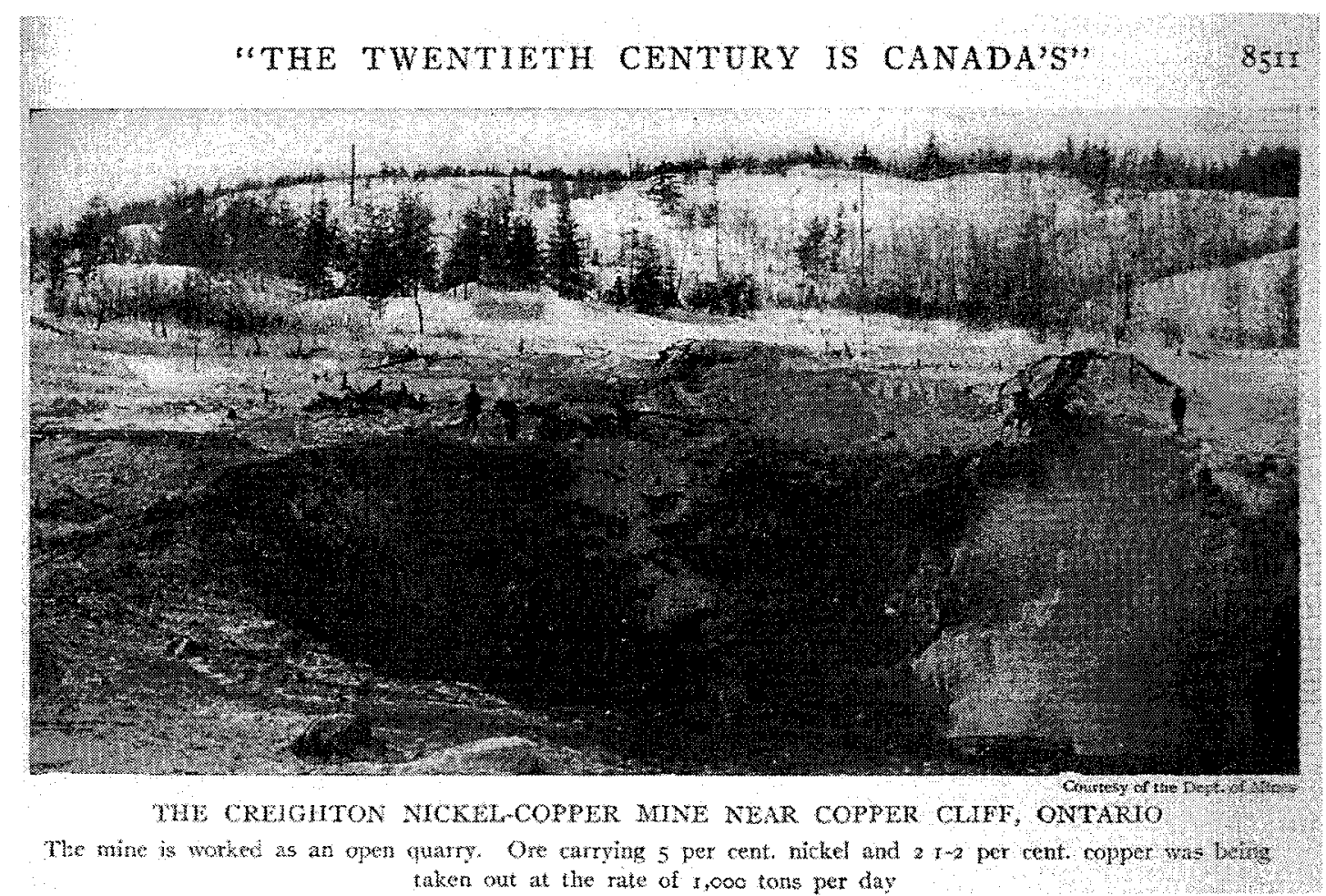

Plate 3: The Creighton Nickel-Copper Mine near Copper Cliff, Ontario Source: Agnes C. Laut, "The Twentieth Century Is Canada's: The Romantic Story of a People Just Discovering Their Own Country," World's Work 15 (1907): 8511. 
in the same way the camera could not easily capture the meaning and direction of the Northern experience for outsiders. The Northwest was isolated from the sense of civilization, capital, and progress associated with 'modernity' by barriers and perceptions of time and space.

The purpose of this thesis is to identify, question and analyze photographic practice in the Athabasca-Mackenzie drainage basin from 1882 to 1914 . These dates respectively mark the points when the first mechanically reproduced images were created of the Athabasca-Mackenzie drainage basin, and when the commercial photographs made of the river system by C.W. Mathers reached their recirculatory zenith. By suggesting this, I not only mean that more of Mathers' photographs were in material circulation than at any other time, but also that the power-knowledge complexes coupled with his images reached a zenith as well. Circulating images of Athabasca and Mackenzie were consolidated in a geographical imagination producing the land as empty colonial space, separating the people by historical time, and envisioning the modern North as 'open.' 1914 is therefore significant as the point when the broad photographic undertaking to represent disparate meanings of North underlined the boosterish clamouring of people like Agnes C. Laut; it was the same year that saw Ottawa's first modern effort to develop the natural resources of the Athabasca oil sands.

Morris Zaslow was the first historian to study the structure of modern northern development. His important work, The Opening of the Canadian North, 1870-1914 described in prophetic terms the process resulting from settlement:

'North-West' and 'North' are more than geographical expressions. They also constitute a process: the advance of frontiers and frontier experience from the rear of the Province of Canada to the prairie northwest, then gradually northward along several fronts to the northern coasts of Canada 
and the islands beyond. Such frontiers were of many kinds - of societies, cultures, and administrations, as well as industries and people. ${ }^{8}$

His broad analysis concluded, not surprisingly, that "in their search for a frontier, Canadians discovered a nation." Unlike earlier historians who viewed the North as passive and ahistorical before the arrival of non-Aboriginals, however, Zaslow understood that "there was more to integrating the new domains into Canada than proclaiming sovereignty over them ... for the territory was no empty void to be shaped de novo to the will of the Canadians." ${ }^{10}$ The people and meanings indigenous to the North were nonetheless depicted as obstacles needing to "adjust" to the "peaceful conquest and redirection" of the region. The impetus behind the 'opening' of the North Zaslow presented was driven by a simple logic: Canada had paid for it, now it would do what it wanted with it. ${ }^{11}$

The word that articulates the thinking Zaslow described, 'colonialism,' is almost absent from his text. More recently, historians Kenneth Coates and William Morrison have shown how colonialism naturalized economic exploitation along the frontier that Zaslow saw between Ottawa and the North. In doing so, they have suggested that the sub-Arctic provincial Norths and the northern territories have become internal colonies of Ottawa. Coates and Morrison largely echo Zaslow when they suggest that, "beginning in 1867, provincial politicians recognized the potential benefits from claiming and holding northern possessions, and they struggled long and hard to expand their hinterlands." "12 Departing from these classical explanations given by historians of colonialism, I argue

\footnotetext{
${ }^{8}$ Morris Zaslow, The Opening of the Canadian North, 1870-1914, The Canadian Centenary Series. (Toronto: McClelland and Stewart, 1971), xi

${ }^{9}$ Zaslow, The Opening of the Canadian North, 3.

${ }^{10}$ Zaslow, The Opening of the Canadian North, 6.

"Zaslow, The Opening of the Canadian North, 14.

${ }^{12}$ Kenneth Coates and William R. Morrison, The Forgotten North: A History of Canada's Provincial Norths (Toronto: J. Lorimer, 1992), 5.
} 
that the metropolitan relationship that developed between Ottawa, Edmonton and the 'frontier-hinterland' conduit, beginning in Athabasca and extending through the Mackenzie River Basin, cannot be understood by looking at social, economic, and political factors alone.

Here I turn instead to J.M.S. Careless's theory that "matters of structure and perception" were central to the successive development of frontier-hinterland relationships that historically and geographically explain the development of Canada. The connections between frontier and metropolis, Careless posed, "might be displayed not only in economic structures, political fabrics, or social networks, but also in attitudes of regard, modes of opinion, or popular images and traditions."13 Through contrasting classical political economy with matters of culture and representation, a new set of issues arise and a new historical explanation of metropolitan exchange takes shape: one that conceptualizes colonialism as a set of productive practices, assumptions, and justifications, not a "rationalization" of dominance. ${ }^{14}$ Postcolonial scholars, following Edward Said's path-breaking work, now ask how metropolitan centres have produced knowledge about the frontier that worked to contain it within the boundaries of an arbitrary geographical imagination. ${ }^{15}$ In Said's formulation, the metropole/European/subject is only able to create itself through differencing, naming, and taking power over the frontier/other/object. Unlike previous studies of northern Canada, this thesis concentrates primarily on photographs to explain colonialism in the frontier-

\footnotetext{
13 J. M. S. Careless, Frontier and Metropolis: Regions, Cities, and Identities in Canada before 1914 (Toronto: University of Toronto Press, 1989), 7.

${ }^{14}$ Edward Said, Orientalism (New York: Vintage Books, 1979), 39.

${ }^{15}$ Said explains that imaginative geographies have distinguished between ours and theirs - that it, the barbarians' - inside the European tradition. "I use the word 'arbitrary' here," he explains, "because imaginative geography of the 'our land-barbarian land' variety does not require that the barbarians acknowledge the distinction." Said, Orientalism, 40, 54.
} 
metropolis bind. I follow the practice of engagement that historical geographer Joan Schwartz suggests for a single photograph: "by looking at it, by looking through it, and by thinking with it, in terms of the meanings that swirled around it, we can achieve a clearer and fuller understanding of time and place, landscape and identity, image and reality." 16

A critical history of photography in the Districts of Athabasca and Mackenzie will elucidate the cultural struggle to represent the North and to locate power in the knowledge of what it means to experience and visualize place. My subtitle, "images, narratives and power' is intentionally reflective of this approach. This study continues the ongoing critique of metropolitanism and colonialism by looking at images as documents pertaining to an historical relationship between the North and colonial interest. Rather than isolate discrete historical facts, I study the production of meaning in and between photographs, thinking with the narratives that situate knowledge and animate regimes of vision. Finally, this thesis is significant to the study of northern Canada because it asks questions of power - looking through photographs for the transparent and implicit matrixes that produced particularly modern discourses of the people and land of the Athabasca-Mackenzie river basin. ${ }^{17}$

\footnotetext{
${ }^{16}$ Joan M. Schwartz, "More Than 'Competent Description of an Intractably Empty Landscape': A Strategy for Critical Engagement with Historical Photographs," Historical Geography 31 (2003): 107.

${ }^{17}$ Peter Geller's recent monograph, Northern Exposures, similarly examines photographic and filmic practices as part of an "extensive project of producing the North as an object of knowledge and understanding." However, differences in subject and approach set this study apart from Geller's important work. Northern Exposures looks at image making of the Inuit and Innu along the Arctic Coast between 1920 to 1945, after the North was 'opened' according to Morris Zaslow and accepted historiography. This thesis instead concentrates on the unfolding relationship between photography, representation, and modernity during the actual 'opening' of the North: the period characterized by the economic transformation from mercantilist colonialism to industrial capitalism at the turn of the twentieth century. Analytically, these projects differ as well. I share Geller's aim to understand "the contexts of production and subsequent display," but take a broader scope than what he defines as the "visual record of northern administration," containing and reflecting strategies of perception between centralized government, HBC and religious institutions, and a broad photographic frontier in the Arctic. Alternatively, I situate my
} 
To re-carve the narrative arcs that struggled to fix and find meaning in images of the North requires the guidance of Laut's picture essay, at once a metaphor and a story that connects this thesis. Chapter 2 begins with the Geological Survey of Canada and officers Robert Bell, and R.G. McConnell's early surveys of the Athabasca during the 1880 s. I suggest that their early forays into the North, which resulted in the discovery of recoverable mineral and petroleum wealth, did not coincide with representational strategies able to communicate the value of the resources. As Laut puts it, "Those were Canada's pioneer days, when the risks were so big and the tasks so hard that men forgot that there could be such a thing as future prosperity."18

In Chapter 3 I examine the relationship between metropolis and frontier as a cultural framework before an economic one. Focusing on big-game hunters and naturalists in the North during the 1890 s, I concentrate on the sentiment historian Jackson Lears has called 'antimodernism. ${ }^{19}$ The term characterizes a widespread dissatisfaction with 'civilized' life in late nineteenth-century North America. However, 'antimodernism' also serves as a powerful analytical tool in explaining how the great fascination with 'primitive' and 'uncivilized' areas of the world reflected a sublimated cultural wisdom that claimed modernity was contaminating white masculinity. Laut's inclusion of a simply-told two-image story of the disappearance of the Plains buffalo highlights the relationship between the two great tools of antimodernism in the North the camera and the gun - as violent and moralizing mechanisms. [Plate 4] The buffalo

analysis between the conflicting metropolitan aspirations of Ottawa and Edmonton, and relate them in turn to the correlative frontiers of the Northwest, Denendeh in the sub-Arctic, and the Far North of the Arctic. Peter G. Geller, Northern Exposures: Photographing and Filming the Canadian North, 1920-45 (Vancouver: UBC Press, 2004), 5-50.

${ }^{18}$ Laut, "The Twentieth Century Is Canada's," 8505.

${ }^{19}$ Lears explains antimodernism as "the recoil from an 'overcivilized" modern existence to more intense forms of physical or spiritual experience." T.J. Jackson Lears, No Place of Grace: Antimodernism and the Transformation of American Culture 1880-1920 (New York: Pantheon Books, 1981), xiii. 


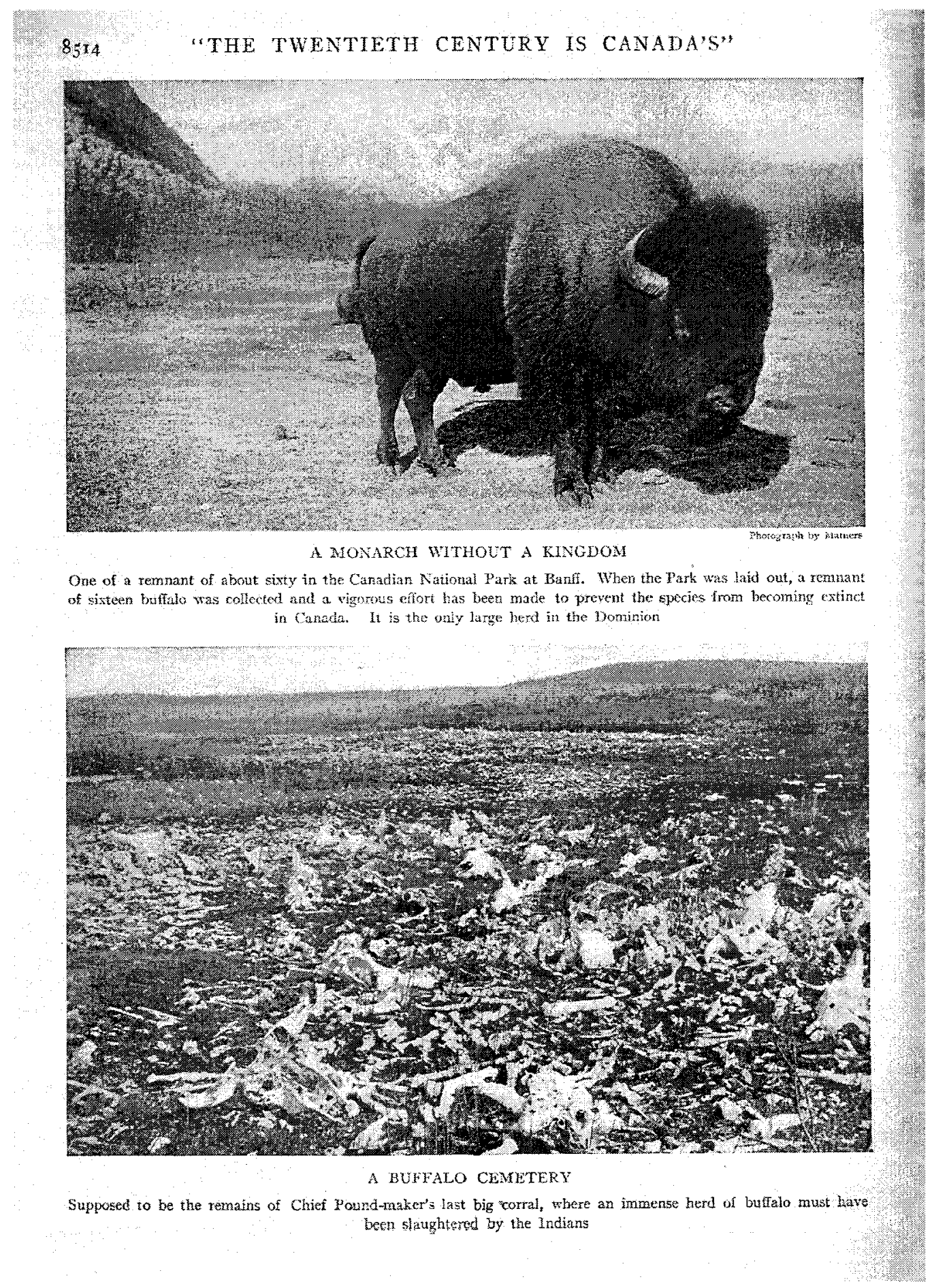

Plate 4: A Monarch without a Kingdom [and] A Buffalo Cemetery

Source: Agnes C. Laut, "The Twentieth Century Is Canada's: The Romantic Story of a People Just Discovering Their Own Country," World's Work 15 (1907): 8514. 


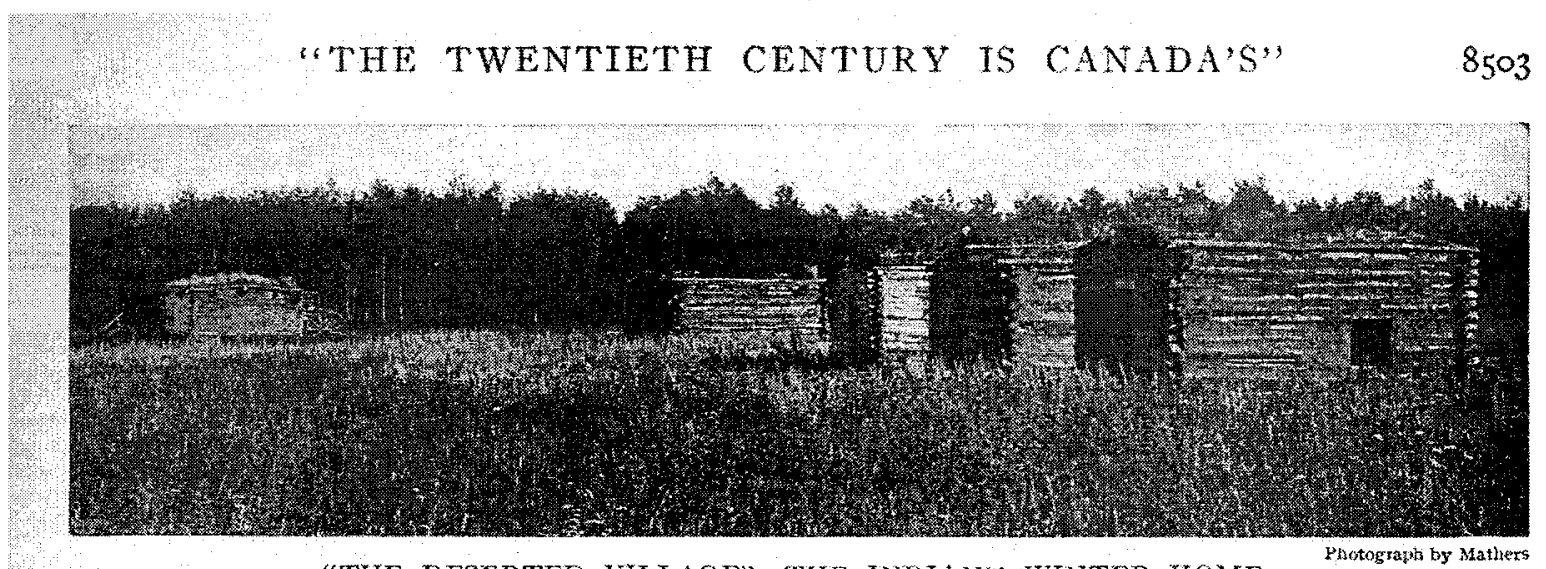

"THE DESERTED VILLAGE" - THE INDIANS" WINTER HOME

Plate 5: “The Deserted Village" - The Indians' Winter Home Source: Agnes C. Laut, "The Twentieth Century Is Canada's: The Romantic Story of a People Just Discovering Their Own Country," World's Work 15 (1907): 8503 . 
had a unique hold on the cultural imagination of the antimodernist. During the $1890 \mathrm{~s}$, the image 'A Monarch without a Kingdom' reflected fears that the last wild places on earth had disappeared into history. The photograph Laut supplied to contrast it with was an early Mathers photograph titled 'The Beginning of Better Things.' The captioned message Laut gave the photographs, "an immense herd of buffalo must have been slaughtered by the Indians," points towards a metropolitan vision: a gaze that looked northward using the camera as an organizing mechanism to explain and often vilify Aboriginal peoples. Chapter 4, which examines a series of images C.W. Mathers created of the North in 1901, continues this theme. I ask why images Laut included in her plea to American capitalists, such as "The Deserted Village - The Indians' Winter Home," had connotations to speculators in the early twentieth century. [Plate 5] I draw upon postcolonial scholarship's engagement with the myth of the 'vanishing Indian' in order to explain the likely reception of Mathers' photographs in Edmonton in 1901, and here also attempt to explain the growing non-Aboriginal interest with the Inuit people of the Arctic Sea in relation to changing attitudes toward the sub-Arctic Native and métis peoples of Denendeh. ${ }^{20}$ I examine the cultural life of Mathers' souvenir book of his voyage to the Arctic, which also supplies the title of this thesis. I ask why and how images originally appearing in the souvenir album, such as 'An Electric Light Station at Fort Simpson,' would have carried and distributed impressions of time and space both into and out of the Far North of the Mackenzie. Why could Charles Mair pause before a 15 meter-high flame of natural gas at the Pelican Rapids on the Athabasca that had been burning uncontrolled for five years in 1899 and find himself, "Standing at the gateway of the

\footnotetext{
${ }^{20}$ For a discussion on my use of 'métis' as opposed to 'Métis' and other issues of Aboriginal naming, see Chapter 3.
} 


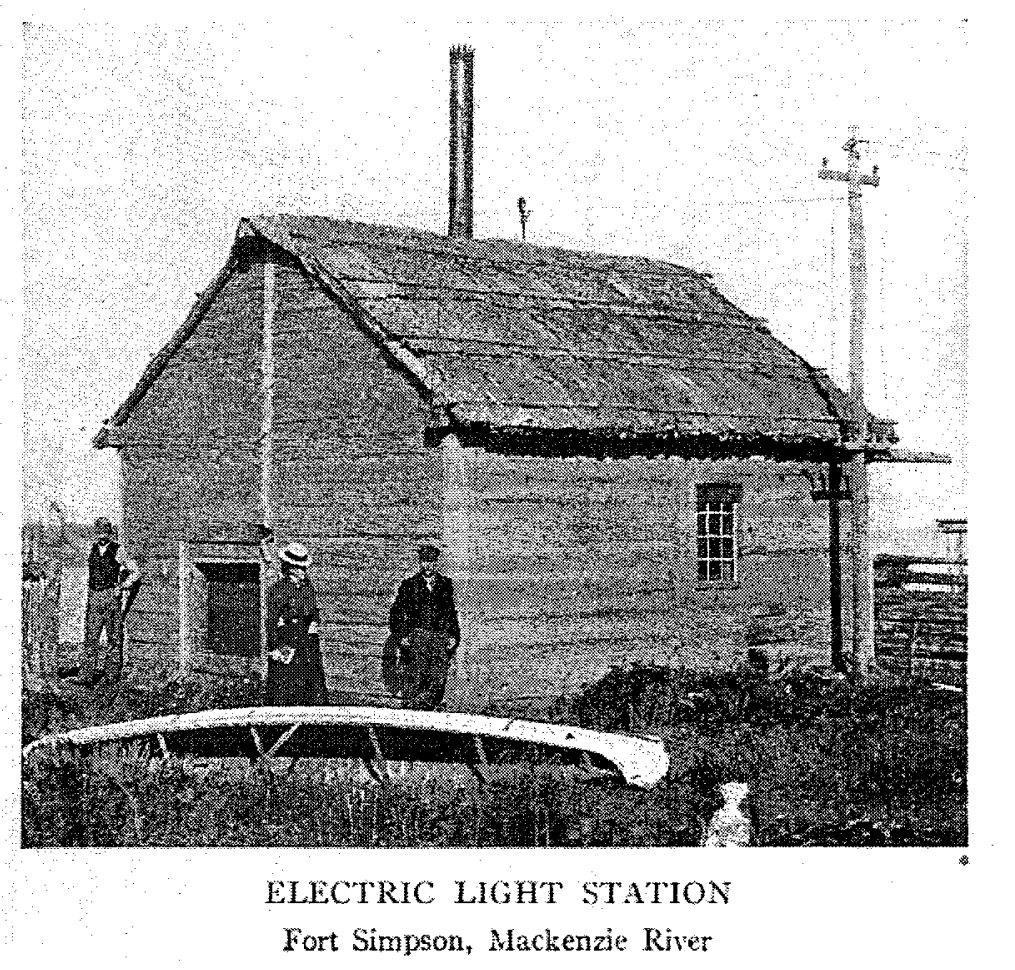

Plate 6: Electric Light Station, Fort Simpson, Mackenzie River

Source: Agnes C. Laut, "The Twentieth Century Is Canada's: The Romantic Story of a People Just Discovering Their Own Country," World's Work 15 (1907): 8513. 
unknown North, and looking at this interesting feature, doubly so from its place and promise, one could not but forecast an industrial future, and 'dream of things to come?",21 [Plate 6]

In reviewing these narratives, Chapter 4 concludes that Mathers' photographs provided a way to envision the North that camouflaged the violent changes brought about by modernity and the expropriation of Native and métis land. I also begin to suggest the importance of what Walter Benjamin so aptly called the 'age of mechanical reproduction' in understanding the Athabasca-Mackenzie river basin at the turn of the twentieth century. ${ }^{22}$ Chapter 5 advances this theme, and asks how the release of Mathers' images from the confines of his authorial book and into a wider market ultimately led to not more meaning being produced by his images, but less - as scientists, historians, explorers, authors, geologists and capitalists all converged around a similar photographic geographical imagination of the future of the land. According to Laut, "Canada's future is that of a New Nation. And if it flies the British flag while American capital develops its resources, there may yet be that commercial compact of an Anglo-Saxon brotherhood of which idealists have dreamed."23

Seventeen years after Agnes Laut published her article, another Canadian historian, Harold Innis, canoed down the Athabasca-Mackenzie in 1924. He was fascinated with "the importance of the economic cyclone of the Klondike to that area."24 Innis witnessed first-hand the geographical pattern of the river system, which had

\footnotetext{
${ }^{21}$ Charles Mair, Through the Mackenzie Basin: An Account of the Signing of Treaty No. 8 and the Script Commission, 1899. (1908; Edmonton: The University of Alberta Press, 1999), 35.

${ }^{22}$ Walter Benjamin, "The Work of Art in the Age of Mechanical Reproduction," in Illuminations, ed. Hannah Arendt (Glasgow: William Collins Sons \& Co Ltd, 1979), 219-254.

${ }^{23}$ Laut, "The Twentieth Century Is Canada's," 8517.

${ }^{24}$ Harold Innis in Carl Berger, The Writing of Canadian History: Aspects of English-Canadian Historical Writing since 1900. Second Edition. (Toronto: University of Toronto Press, 1986), 97.
} 
determined the extent and route of the fur trade, bear the full force of the technological attempt to conquer it. The fur trade had not given way to the gold rush then given way to mining and the future development championed by Laut in a neat and orderly pattern of succession, but unfolded chaotically to the extent that its only rules were the abstract principle of supply and demand for staple goods versus the relative difficulty of geographical barriers. The violent metropolitan push into the hinterland led Innis to postulate that Canadian history, "has been dominated by the discrepancy between the centre and the margin of western civilization," but also that developments and obstacles in the frontier peripheries were essential to shaping innovation and new technologies in metropolitan centres. ${ }^{25}$ Innis's realization that relations of power could be explained by studying the relationship between technology and space, forced him to reconsider the nature of staples as they moved through it. In place of market-systems, he began to see staples as media of communication producing, but also limiting, metropolitan empires of information. "A medium of communication," Innis decided, "has an important influence on the dissemination of knowledge over space and over time and it becomes necessary to study its characteristics in order to appraise its influence in its cultural setting." 26 This thesis thinks along with Innis by situating photography as a medium of communication at the centre of the 'cyclone' that blew into the North between 1882 and 1914, but it also takes his thinking beyond the cultural, spatial, and postcolonial turns, asking what meanings photography carried with it, what meanings it was limited from making, what new meanings it made possible, and finally, what meanings it carried away.

\footnotetext{
${ }^{25}$ Innis in Berger, The Writing of Canadian History, 97.

${ }^{26}$ Harold A. Innis, The Bias of Communication (1951; Toronto: University of Toronto Press, 1991), 33.
} 


\section{Chapter 2: The Geological Survey of Canada, 1882-1890}

\section{Introduction - The Utilitarian Spirit}

Established in 1842, the Geological Survey of Canada was, intellectually at least, the protégé of an earlier British impetus known as the 'geographical' tradition.

Succinctly described by Suzanne Zeller, its function was to "explore and to exploit new lands all over the world." Marked by the opening of the world to English travellers armed with new instruments of record and precision, the imperial desire to possess colonies coincided with the positivist spirit of classification and general amassing of knowledge. Zeller argues that, while the Geological Survey of Canada was framed by its first officer, Sir William Logan, as profoundly utilitarian, "for the benefit of science and our country," the rhetoric that science led to egalitarian progress also worked to conceal nation-building aspirations in Upper Canada. ${ }^{2}$ Historical geographers have understood the scientific advances of the nineteenth century as those that drastically re-defined time and space. The codification and collapse into knowledge of the flora, fauna, and larger geographical and geological systems that covered the North American sub-continent north of the United States seemed to make possible the transformation of that knowledge into a country. Two different systems of representation were at work here: to trace the boundary line around Canada as a transcontinental nation meant first filling in the information contained within the lines. Photographic practices were fundamentally involved in the overall project.

\footnotetext{
' Suzanne Zeller, Inventing Canada: Early Victorian Science and the Idea of a Transcontinental Nation (Toronto: University of Toronto Press, 1987), 4.

${ }^{2}$ Zeller, Inventing Canada, 5.
} 
In 1879 the federal Surveyor-General, Lindsay Russell, sent a letter from the Dominion Lands Office to Dr. Robert Bell asking him to describe the geography of the upper part of the Shell River and the terrain around Buggy Creek. Bell, a full officer of the Geological Survey of Canada, fulfilled his request. Russell's response was a common enough nineteenth-century reaction, "I found your letter and the photographs you have so kindly sent me .... The plates are most interesting, conveying as they do, more than any words, a good idea of a part of the country I have never seen." 3 The primacy given to 'seeing' over 'reading' and other forms of descriptive knowledge-gathering reveals a massive shift in the hierarchy of an empirical epistemology adjusting to secure photography as a 'scientific record', and yet it masks another important change. Bell's images came from the Geological Survey Library, and the significance of Ottawa as a central archive of knowledge of Canada should not be missed. But Russell's request came from the Yukon while Bell's images and response came from Ottawa. Photographs did not just convey to the viewer what it was like to be there, but actually projected the knowledge from Ottawa, the metropolis, to the frontier, the Yukon. The intimate binds of structure and perception located by Careless in his Metropolitanism thesis meant that photographs not only described, figuratively, but they conveyed experiences as well. They became tantamount to being there. The Yukon was effectively 'imaged' by Ottawa, as far as Russell was concerned.

Thus, this story begins with the voyage of Robert Bell into the Mackenzie River basin by way of the Athabasca. The attempt made to 'record' the region through experience therefore not only consisted of taking photographs, but also meant seeking

\footnotetext{
${ }^{3}$ Robert Bell Fonds (LAC) MG29 B15 vol.32 file.10, "Correspondences," Lindsay Russell to Robert Bell, 6 January 1879.
} 
photographs that conveyed and placed on the land "a good idea" of what it should mean and represent. The task of producing images that coincided with the designs of Ottawa, however, was neither simple, one-directional, nor without resistance. Hence, Robert Bell's exploratory survey to the District of Athabasca was task requiring far more than making pictures that unequivocally communicated a pre-established set of ideas.

In 1882, Bell, civil engineer and officer of the Geological Survey of Canada, packed his surveying and recording equipment, boarded a train, and wound his way into the vast northern rivers of the North-West Territories. ${ }^{4}$ At the behest of GSC director Dr. Alfred Selwyn, Bell and his assistant, A.C. Lawson, departed with the mission to "examine and survey that portion of the Athabasca River hitherto unsurveyed between the confluence of the Lake La Biche River and the Clear Water River [sic]; and further to examine as much as possible of the great, wholly unexplored, region south of Athabasca Lake, and lying between the Athabasca River and the $108^{\text {th }}$ degree of longitude. ${ }^{.5}$ Bell would later note that they were also to investigate "the relations of the rocks of the river below the latter stream [the Clearwater], especially with reference to the mode of occurrence of petroleum and asphalt."

\section{Early Visions of the North}

Bell's voyage was an initial survey of the Athabasca-Mackenzie basin for Ottawa. Apart from his federal association, and apart from earlier European explorers, he was also

\footnotetext{
${ }^{4}$ Robert Bell Fonds (LAC) MG29 B15 vol.2 file.6, "Correspondences," Robert Bell to Alfred Selwyn, 'Preliminary Report of the Exploration of 1882.'

${ }^{5}$ Geological and Natural History Survey of Canada, Report of Progress for 1880-81-82, prepared by Alfred Selwyn (Montreal: Dawson Brothers, 1883), 15.

${ }^{6}$ Bell in Geological Survey of Canada, Report on Part of the Basin of the Athabasca River, North-West Territory: 1882-3, prepared by Robert Bell (Montreal: Dawson Brothers, 1884), ii.
} 
the first person to apply the science of exploration to the northern districts. Upon his return from the District of Athabasca, the esteemed scientist reported that,

Where the contact of the sand petroleum-bearing strata with the higher Cretaceous rocks was seen at the Drowned Rapid, it was observed that the oil was prevented from passing upward by tenacious clayey strata. It may occasionally find an upward passage through these confining argillaceous beds, and this would account for the isolated springs or wells of petroleum which are reported as occurring in various parts of the AthabascaMackenzie country. ${ }^{7}$

With an uncanny gaze that penetrated the very earth, Bell revealed not only the processes through which petroleum rose to the surface of the oil sands around Fort McMurray, but was able to see into the future, to notify Ottawa that here was the economic future of Canada. Bell described his experience as feeling "struck ... with the immense geographical extent of the natural indications of this substance as well as the enormous surface showings." ${ }^{\prime 8}$ He attached a sketch that may have been from a photograph to his report showing the Athabasca River and its limestone banks. [Plate 7]

Botanist John Macoun had passed the same region in 1875, but concluded that the black shale on the surface was the source of the fuel. ${ }^{9}$ Bell's new assertion meant that the small amount of petroleum in the black shale of the surface would have produced an "inexhaustible supply of fuel" and could now be seen as underground lakes of riches. ${ }^{10}$ In an Ottawa lecture of 1883 , Bell fantasized to petroleum interests in the Canada Institute that "from all appearances the petroleum occurs in such unlimited quantities in the Athabasca region above described that it may be regarded as the great future oil-field

\footnotetext{
7 Part of the Basin of the Athabasca River, prepared by Bell, 24.

${ }^{8}$ Robert Bell, "Petroleum in the North West Territories," (paper presented at the Canadian Institute, Canadian Institute, n.d. 1883),

9 Report of Progress for 1880-81-82, prepared by Selwyn, 15.

${ }^{10}$ Part of the Basin of the Athabasca River, prepared by Bell, 34 .
} 


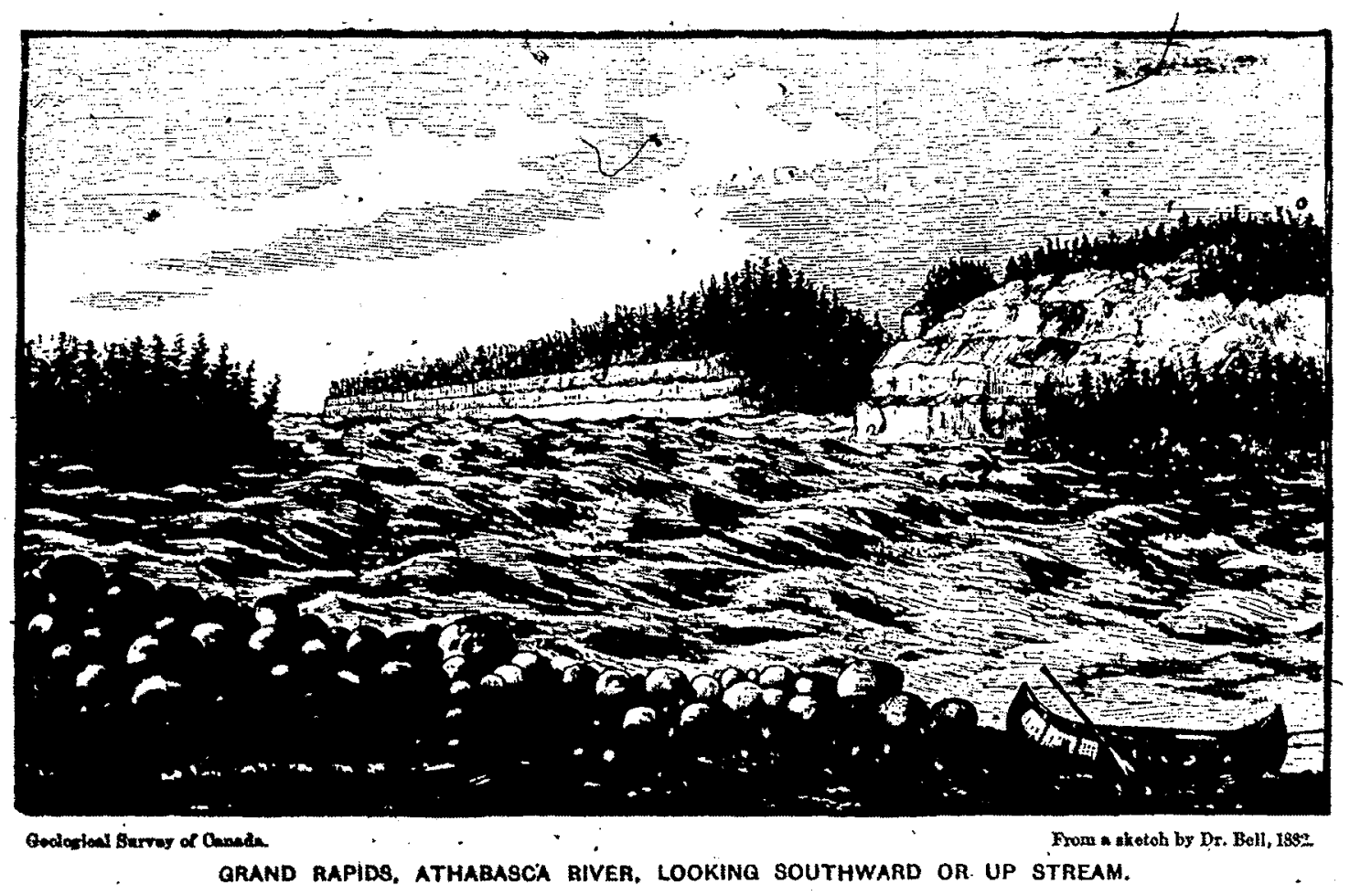

Plate 7: Grand Rapids, Athabasca River, Looking Southward or Up Stream. Source: Geological Survey of Canada, Report on Part of the Basin of the Athabasca River, North-West Territory: 1882-3, prepared by Robert Bell (Montreal: Dawson Brothers, 1884), 10. 
of North America, if not the world, and it may be looked to for a permanent supply after the known sources of oil in the United States have been exhausted."11

Bell may still be correct, but it was not until 1914 that the first teams reached Fort McMurray to begin extracting the rich supply of oil. What happened in the intervening thirty years that it took such time to organize and tap the resources of the North? Certainly large petroleum interests had to be arranged and the federal, territorial, and later provincial governments needed to be brought onside. I do not dispute this; however I do suggest that the process was more complicated, and involved not Bell's success in describing the North as the economic future of Canada, but his failure in representing it. Bell's reading of the rocks could see the material future of Canada - but he could not photograph it. Bell's inability to photograph and display the future of Canada was the result of three factors. The first is quite evident. During the $1880 \mathrm{~s}$, photography was relatively new to the GSC and limited as a practice of recording. The dominant practice of producing and circulating knowledge gained by exploration in a visual form remained the map - the discourse and dialectic of mapping and topography being the second factor. Third, a typically overzealous Bell overstated the bounds of his colonial aspirations for the North. His vision of the North as agricultural boon, mining future, and settlement opportunity outreached the more reserved aspirations of Ottawa, not greatly concerned with the North at the time.

\section{Photography}

Bell had planned well ahead for his voyage by writing to Hudson's Bay Company factor James Bissett to request letters of introduction to their posts in the Far North; ordering the explorer's staple Peterborough canoes and arranging for their transport to

\footnotetext{
$"$ Bell, "Petroleum in the North West Territories,"
} 
Athabasca Landing; preparing the musk-ox robes he had acquired in $1879 ;^{12}$ and finally picking up the $\$ 90$ camera and lens he purchased in Ottawa from the Montreal landscape photographer, Alexander Henderson. ${ }^{13}$ The GSC had employed photography since 1860 , when James Richardson documented his field work in Newfoundland with a set of glass plates using the wet collodion process. ${ }^{14}$ The initial work of photography in the field involved the portaging of hundreds of pounds in photographic materials and solutions. In 1871, GSC director Alfred Selwyn's survey of the BC interior included 450 lbs. of photographic equipment, out of the party's $3600 \mathrm{lb}$. burden. ${ }^{15}$ As well, climatic conditions had to be just right to create images. One itinerant ethnographic artist from the north shore of Lake Superior lamented his inability to "carry a gallery around amongst the Indians" after his darktent blew away for the last time. ${ }^{16}$ Long exposure times meant that photographers were limited to depicting stationary objects or creating scenes that gave the illusion of movement, until "instantaneous" photography during the 1860 s gave photography the ability to picture just a second of time. ${ }^{17}$ By the mid 1870 s, the technology was becoming mobile, and Bell plus a group of other officers at the GSC, including G.M. Dawson, Alfred Selwyn, and Thomas Weston, had incorporated photography as a regular practice in their field surveys. ${ }^{18}$ Bell followed other officers of the Survey, such as Selwyn and Dawson, in recognizing the broader applications of

\footnotetext{
${ }^{12}$ Robert Bell Fonds (LAC) MG29 B15 vol.14 file.14, "Correspondence," James Bissett to Robert Bell, 4 May 1882 .

${ }^{13}$ Robert Bell Fonds (LAC) MG29 B15 vol.20 file.85, "Correspondence," Alexander Henderson to Robert Bell, 1881 .

${ }^{14}$ Peter Robertson and Andrew Rodger, "Photography and the Geological Survey of Canada," The Archivist 19.3 (1992): 11.

${ }^{15}$ Laurie A. Beckwith, An Introduction to the Geological Survey of Canada Photographs at the National Archives of Canada (Unpublished: National Archives of Canada, 1999), 3.

${ }^{16}$ H.C. Fraser, "Photo," Canadian Journal of Photography 1.2 (1875): 17.

${ }^{17}$ Joan M. Schwartz, "Photography at the Speed of Life," Queen's Quarterly 108.3 (2001): 431.

${ }^{18}$ Beckwith, An Introduction to the Geological Survey of Canada Photographs, 3.
} 
photography in print and in public lecturing, having his images engraved to accompany reports or made into slides for magic lantern presentations.

By the time he was instructed by Selwyn to depart for Athabasca, Bell was renowned by scientists in Canada and the U.S. for his photographic skills. Shortly after his return from the Athabasca trip he was made an honorary member of the Association of the Dominion Land Surveyors, with whom he eagerly circulated his photographs. ${ }^{19}$ It is unclear whether any of these images were of the Mackenzie and Athabasca regions. Though we can gather that Bell made images of his voyage through hazy indicators in his archive to the '1882 plates' and a flurry of correspondence with a wood engraver in December of the same year ensuring that Bell's photographs would be transformed into printable woodcuts, the photographs do not appear to exist today. ${ }^{20}$ The woodcuts that ended up accompanying Bell's narrative of the voyage are of various Devonian rock formations and the one image Bell made of his canoe resting on the shore of a turbulent Athabasca River, the black shale rocks of the petroleum fields in the background. [Plate 7] The half-tone technique that made mass-reproducible photographs printable was available by 1880 , but would not be widely used until closer to the turn of the century. Before photographs were securely interwoven into the story of the GSC, Morris Zaslow notes that it was "through the reports, articles, and lectures of its personnel, but especially through its exhibits at the great international fairs, the Survey played an important role in making an interested world aware of Canada's potentialities." ${ }^{, 21}$ While the importance of

\footnotetext{
${ }^{19}$ Robert Bell Fonds (LAC) MG29 B15.13 file.22, "Correspondence," Association of Dominion Land Surveyors to Robert Bell, 15 March 1884.

${ }^{20}$ Robert Bell Fonds (LAC) MG29 B15 vol.36 file.34, "Correspondence," J.H. Walker to Robert Bell, 4 December 1882; Robert Bell Fonds (LAC) MG29 B15 vol.44 file.12. "Photography - Memoranda."

${ }^{21}$ Morris Zaslow, Reading the Rocks: The Story of the Geological Survey of Canada, 1842-1972 (Toronto and Ottawa: Macmillan Company of Canada, Department of Energy, Information Canada, 1975), 3.
} 
fairs and exhibitions was not waning during the 1880 s, photographic technology was infiltrating the ordinary practices of the Survey's members. Bell, as early as 1868 , had developed an interest in 'Phantasmagoria Lanterns' or magic lantern slide shows, an "apparatus for exhibiting dissolving views, transparent photographic views, and statues" onto a screen or wall. ${ }^{22}$ Plates 8 and 9 show different photographic end-results, a lantern slide used in Bell's public lectures and a sketch produced of the same scene for the report on his 1878 reconnaissance survey northeast of Lake Winnipeg. ${ }^{23}$

Art historian and theorist Jonathan Crary has described how mechanical optical devices, such as the Magic Lantern, manufactured new subject-observer positions posited on the rational modern individual in a hegemonic form of binary Cartesianism - the viewer became the knower of "a pre-given world of objective truth." 24 Crary suggests that by the end of the sixteenth century, the camera obscura had assumed "a pre-eminent importance in delimiting and defining the relations between observer and world.",25 James Ryan offers a more suggestive interpretation of the relationship between subjectivity and vision as the nineteenth century drew to a close: public lantern-slide lectures in Britain became a favoured "means of projecting a robust and unifying vision of Empire onto the popular imagination." ${ }^{26}$ Bell, who in the early 1880 s was the first of the Survey's staff to have the Ottawa photographic specialist W.J. Topley begin making lantern slides to accompany his public talks, might have recognized the powerful

\footnotetext{
${ }^{22}$ An advertisement found in Bell's papers from $\mathrm{H}$. Sanders in Montreal describes the Phantasmagoria Lantern as coming equipped with one of three possible pre-fabricated shows - 'astronomy', 'comedy' or 'natural history' - one of which apparently interested the sombre Dr. Bell. Robert Bell Fonds (LAC) MG29 B15 vol.44 file.12, "Photography - Memoranda."

${ }^{23}$ Zaslow, Reading the Rocks, 121.

${ }^{24}$ Jonathan Crary, Techniques of the Observer: On Vision and Modernity in the Nineteenth Century (Cambridge, Mass: MIT Press, 1990), 38.

${ }^{25}$ Crary, Techniques of the Observer, 38.

${ }^{26}$ James R Ryan, Picturing Empire: Photography and the Visualization of the British Empire (Chicago: University of Chicago Press, 1997), 191.
} 


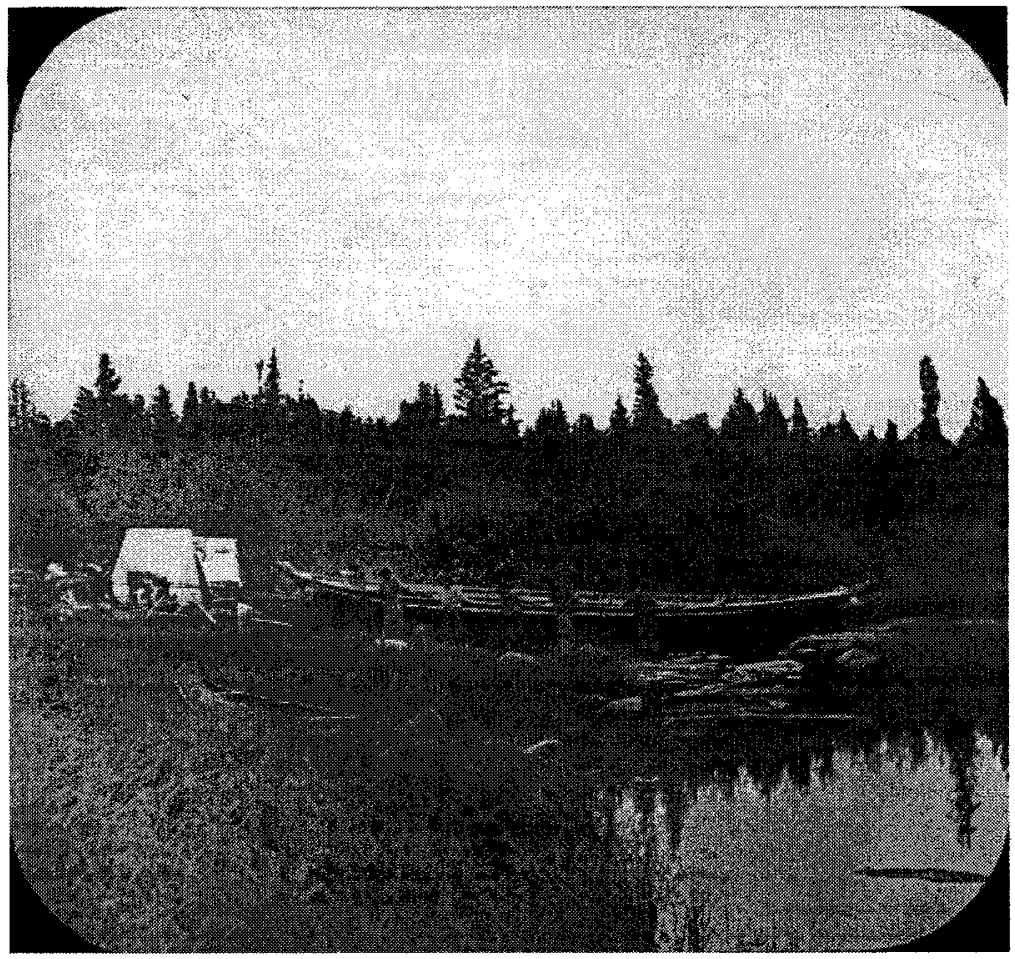

Plate 8: [Hauling a York Boat, 1878. A lantern slide] Source: e005580821 Robert Bell Collection (LAC) 1984-318 NPC

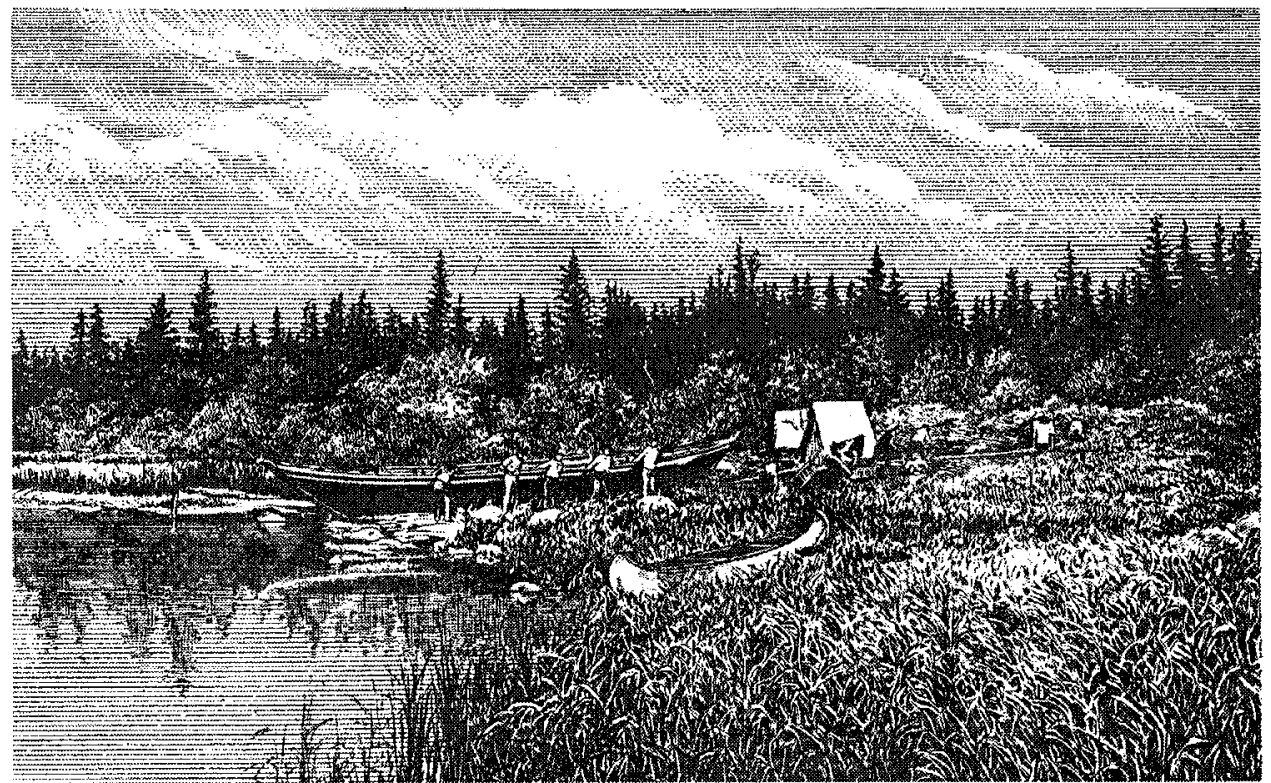

Plate 9: [Hauling a York Boat, 1878. An engraving]

Source: Morris Zaslow, Reading the Rocks: The Story of the Geological Survey of Canada, 1842-1972 (Toronto and Ottawa: Macmillan Company of Canada, Department of Energy, Information Canada, 1975), 121. 
impression that an illustrated lecture could deliver. In 1883 he delivered two lectures concerning his voyage to the Athabasca-Mackenzie Basin. While in England, slides of colonial encounters helped assuage fears that the health of the Empire was faltering, slides in the colonies often suggested the empire yet to come - as Bell informed the attendees of his honorary Somerville Lecture given at the Hall of the Natural History Society in Montréal: "we may expect to find in the northern region ... the future Colorado and Nevada of the Dominion of Canada." 27 The 1883 lecture was the first release of information gathered on the Athabasca survey the previous year. Espousing a grand vision of Canada's destiny in the North, Bell's talk also revealed the pressures and contestations of knowledge-making that underlay the voyage.

Morris Zaslow points out that geologists “are not employed by governments for the primary purpose of contributing to the increase of theoretical geological knowledge; geological surveys, in Canada and elsewhere, were established with the objective of advancing the mining economy of the province." 28 Although mining and industry guided the GSC's mission and message heavily, it was nevertheless under attack in 1884 from Prof. E. Chapman, Chair of Mineralogy and Geology at the University of Toronto. In a series of news articles he charged the officers with producing "too much science and too little useful knowledge." 29 While Chapman was opaque in explaining what "useful knowledge" was, others were sure of it. Bell was careful to present his lectures in an 'unscientific' manner that highlighted the undeveloped resources of the Northwest: "no less than 100 millions of tons of good hay are lost in each of the last years ... one cannot

\footnotetext{
${ }^{27}$ Robert Bell, "The Athabasca-Mackenzie Basin," (paper presented at the Somerville Lecture, Hall of the Natural History Society, 1 March 1883).

${ }^{28}$ Zaslow, Reading the Rocks, 34.

${ }^{29}$ E. Chapman, Toronto Mail 7 April 1884.
} 
help thinking that a time may come when a part of this will be utilized by pressing and enforcing it by the short route through Hudson's Bay to Europe, where hay commands a high price." 30 The idea that the northern part of the Northwest, as opposed to the south, would be the next great locus of settlement ran contrary to the earlier conclusions of fellow GSC member, Professor John Macoun. During the 1870s, Macoun, a botanist, had characterized the North as hostile and unproductive, and declared that the 'fertile belt' which skirted the US border would be the real focus of growth. ${ }^{31}$ In contrast, Bell proselytized for a railway from Red River to Churchill Harbour on Hudson Bay, a route he had explored in $1879 .^{32}$ His 1883 lectures on the Athabasca-Mackenzie basin mobilized the linear logic of geography to present his case; although departing from his earlier rhetoric, he located the terminal at Athabasca Lake as opposed to Red River:

We are accustomed to consider the years of the Peace and Athabaska Rivers so far away as to be almost inaccessible, but if the simple lack of railway referred to were built these lands could be as easily reached as were the furthest parts of Upper Canada only a short time ago. Churchill Harbour, although more than half way across the continent is nearer to Liverpool than we are here in Montreal and a full days steaming nearer than New York. This may seem almost incredible, but it is accounted for by the fact that both Liverpool and Churchill are a good deal further north than New York or Montreal and owing to the narrowing of the meridians in that direction, a great circle drawn between the seaports referred to, actually measures rather less than one drawn from Montreal to Liverpool. $^{33}$

\footnotetext{
${ }^{30}$ Bell, "The Athabasca-Mackenzie Basin."

${ }^{31}$ Douglas Owram, Promise of Eden: The Canadian Expansionist Movement and the Idea of the West, 1856-1900 (Toronto: University of Toronto Press, 1980), 150-158.

${ }^{32}$ Owram provides an explanation of Bell's enthusiasm for settlement using a description given of the Survey officer by Charles Tuttle from the deck of their vessel in Hudson's Bay: "He could not be persuaded it rained when it poured; or that there was any wind, when it blew at a gale of thirty miles an hour; or that there was any ice, when the Neptune was rearing and plunging in the midst of it like a mad bull; or that it was cold, when the mercury was down to 32 degrees above, and when he was pacing the deck, compelled to wear a good coat of reindeer; in fact he was prepared to believe that the propeller had hit a whale rather than ice." Owram, Promise of Eden, 188.

${ }^{33}$ Bell, "The Athabasca-Mackenzie Basin."
} 
Accentuating the power over distance Bell saw in steam, an undated lantern slide Bell kept in a box labelled 'Mackenzie River' showed the HBC steamer, Grahame, on Great Slave Lake. ${ }^{34}$ If a rubric of 'steam-powered transportation' can be accepted, then through railways the marriage of photography and steam-powered technology has been wellanalysed. Brian Osborne has explored the way the Canadian National Railways used photographs during the 1920 s as 'dynamic sites' ready for representational meaning to link visually signified immigrant identities with their racial viability as settlers. ${ }^{35}$ As a productive discourse, the photographs used by the CNR were employed a normative and limiting practice capable of managing mass populations in transit in order to 'engineer the state. ${ }^{36}$ It is likely that Bell's lantern slides accompanied the public lectures he delivered on the development, settlement, exploitation, and transportation that would link the North to Ottawa and a world market.

The focus of Canadian life had shifted to the Northwest with increasing intensity since the HBC agreed to sell Rupert's Land to the Dominion of Canada in 1869. Douglas Owram argues that, after the Assiniboine and Saskatchewan Exploring Expedition of 1858 led by Henry Youle Hind, "geographical perceptions had altered not only according to scientific theory but also to meet the expectations of the nation. ... Science and geography responded to the perceived needs of the Canadian nation and in so doing reflected the wider social, economic, and political currents that were affecting the nation

\footnotetext{
${ }^{34}$ Robert Bell Fonds (LAC) MG29 B15 "FA-267."

${ }^{35}$ Brian S. Osborne, "Constructing the State, Managing the Corporation, Transforming the Individual: Photography, Immigration, and the Canadian National Railways, 1925-30," in Picturing Place: Photography and the Geographical Imagination, ed. Joan M. Schwartz and James R. Ryan (London: I.B. Tauris, 2003), 163.

${ }^{36}$ Osborne, "Constructing the State," 168.
} 
at the time." ${ }^{37}$ Social forces also shaped the perception and apprehension of the GSC's work in the Northwest.

With the intention to curtail some of the more tangential directions of the Survey, a government review in 1884 claimed that, "the reports [of the Northwest] contained entirely too much trivia as details of scenery or anecdotes of Indians." 38 American anthropologist Franz Boas, writing to Bell, contrasted this assumption with his fears that Natives were a 'vanishing race,' urging the Survey officer to prioritize his values: "both, geography and ethnography of Arctic America are equally important, but the tasks of the latter are more pressing. There is no doubt, that within a few years many ethnographical facts will be innumerably lost and the questions can not be settled in one year."39 Bell, whose written reports made no mention of Native peoples, published articles in Boas's own. Journal of American Folklore. Outside of his commitment to the Survey, he delivered lectures on Native ways of knowledge. Like most others, even Bell's 'enlightened' logic of difference betrayed itself as homogenizing, "many people speak of 'the Indians' as if all tribes were alike in every respect. But, in truth, there are great differences. .... I have also had some experience of the Eskimo, who differ widely from all the other aborigines of the continent, and who are not ranked as Indians at all.",40

The vanishing Native presence, the intersection between the mineral future of the Athabasca-Mackenzie Basin, the favourable conditions of agriculture, the possibilities of railways bypassing the longer route through Edmonton and Winnipeg, and the colonial future of the North were all assembled in Bell's lecture:

\footnotetext{
${ }^{37}$ Owram, Promise of Eden, 149.

${ }^{38}$ Zaslow, Reading the Rocks, 140.

${ }^{39}$ Robert Bell Fonds (LAC) MG29 B15 vol.14 file.36, "Correspondence," Franz Boas to Robert Bell, 1885.

${ }^{40}$ Robert Bell, The 'Medicine-Man'; or, Indian and Eskimo Notions of Medicine, a Paper Presented at the Bathurst and Rideau Medical Association (Montreal: Gazette Printing Company, 1886), 2.
} 
In time no doubt many others will be found as well as new localities for those already known. Few of them will be of much value as long as the country remains in its present ... and undeveloped condition, but the time is rapidly approaching when all this will be changed, and the valuable metallic ores as well as the coarser mineral substances, which I have mentioned, will become valuable and many of them absolutely necessary in the progress of the occupation of the country by civilized man. ${ }^{41}$

Bell was able to visualize a metropolitan relationship with the North through the eyes of central Canada. Material wealth was not the end of settlement - progress itself was the dictum. The main reason for extracting ore would be to build the railways so that the trains could move it. Even the hot springs that Bell understood to be golden evidence of a "new Colorado" served a manifest purpose in expansion: "these springs have, no doubt, valuable medicinal properties, and being situated in a picturesque locality, they may at some future time become resorts for invalids, when this part of the Northwest Territory shall have been opened up by railways and peopled." ${ }^{42}$ Bell could see the future quite clearly and was able to negotiate the competing visions of Canada's future in the Northwest and the Geological Survey's function in realizing it.

Bell's position illustrates that, like photographs, a providential explanation of frontier and metropole is one that is directional, progressive, natural, and stable across time and space. But, like photographs, this appearance is the result of an intentional representation - one that exists in overlapping and shifting meanings always pointing to another level of legitimization, resisting the very qualities of stability it seeks to present. ${ }^{43}$

\footnotetext{
${ }^{41}$ Bell, "The Athabasca-Mackenzie Basin."

${ }^{42}$ Part of the Basin of the Athabasca River, prepared by Bell, 27.

${ }^{43}$ Canadian historiography of the North reflects this juncture. Upon the cue that Canada had finally moved from 'colony to nation,' in 1971 Morris Zaslow dislodged Canadian historical consciousness of the North from its moorings by suggesting Canada was a Northern nation, as W.L. Morton had described, because it moved equally northward in relation to the perceived westward progression of metropoles. In 1992 Coates and Morrison claimed that the internal colonialism of Canada means that provincial Norths are frontiers of southern provincial metropoles, in turn frontiers of Ottawa. In 1993, alternatively, Kerry Abel's Drum Songs proposed that the category of 'colony' or 'frontier' was incompatible with the Dene nation of the
} 
Efforts to picture the North must therefore engage, and evade, relationships of distance, place, time, and difference. Recognizing that representation binds and reveals such matters of political economy, we must also ask how the thirty years of inactivity that preceded government expansion into the Mackenzie related to Bell's inability to photograph it.

\section{Movement}

Bell and his assistant A.C. Dawson had spent less than a year in the North, but this was hardly the way they registered their voyage. Rather than frame the time or length of their 1882 voyage to the Athabasca-Mackenzie basin, Bell's own summation of the survey was that, "the distance travelled by rail from Ottawa in the spring and returning in the autumn amounted to about 3,460 miles, so that the total distance covered during the season was about 5,600 miles."44 Exploration and reconnaissance was a spatial endeavour that could be plotted geographically, and for Bell space became a way of explaining his traverse of the rugged terrain and vast river-system of the AthabascaMackenzie drainage basin. Not long after being hired at age fifteen in 1857 by the Survey's legendary founder, William Logan, Bell began effecting change in the way that maps and distances were created and understood by the staff. By the $1860 \mathrm{~s}$, he had already gained a reputation for privileging exploration and mapping in favour of geological sampling and had begun to develop his own technique of 'reconnaissance"

\footnotetext{
North, whose culture has proved resilient and dynamic in the wake of colonizing efforts. In 2002 Janice Cavell would charge that historians invented the North in order to make Canada a coherent and transcontinental whole: "national history" she writes, "with its illusions of inevitable development and predetermined destiny, is a cultural construct rather than a straightforward relation of facts." Janice Cavell, "The Second Frontier: The North in English-Canadian Historical Writing," Canadian Historical Review 83.3 (2002): 367; Kerry M Abel, Drum Songs: Glimpses of Dene History (Montreal and Kingston: McGillQueen's University Press, 2005); Coates and Morrison, The Forgotten North: A History of Canada's Provincial Norths; Zaslow, The Opening of the Canadian North.

${ }^{44}$ Part of the Basin of the Athabasca River, prepared by Bell, 7 .
} 


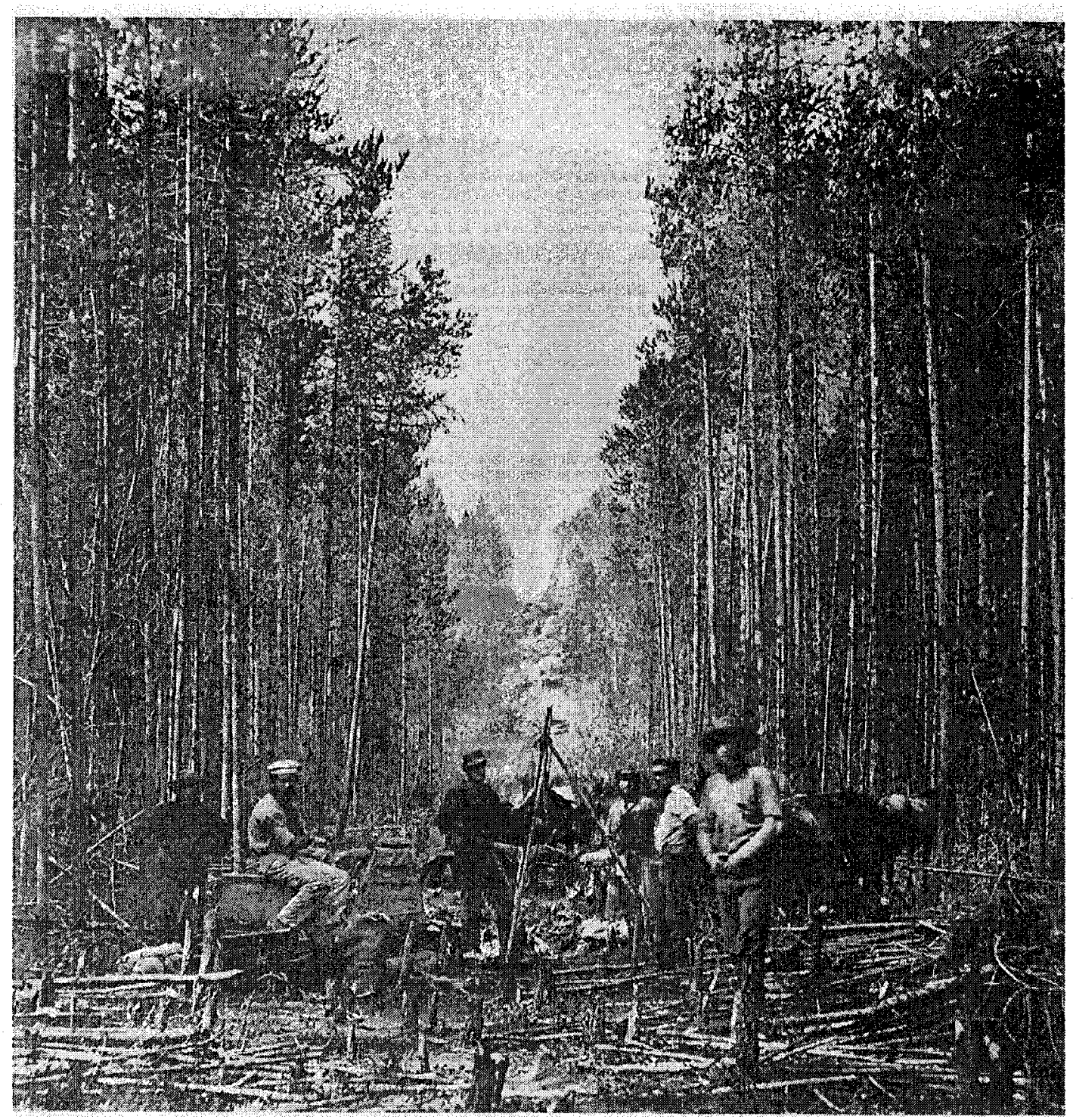

Plate 10: [Cutting the $49^{\text {th }}$ Parallel]

Source: PAC-C78979 The Institute of Royal Engineers, Chatham, England, $1860-1$ 
surveying. ${ }^{45}$ In the Survey's Report of Progress for 1866-69, Bell outlined his approach: "Throughout the season, I worked upon the principle we have always pursued upon the Geological Survey, in exploring or surveying in a new region namely, that of following, as much as possible, the water-courses, instead of cutting 'exploratory lines.",946

'Cutting the $49^{\text {th }}$ Parallel' communicates a powerful visual metaphor of 'exploratory lines,' but also expresses the great work required to penetrate, render, and divide the forest visually. [Plate 10] After concluding that a trained member of the Royal Engineers must have created the photograph, Martha Sandweiss described the image as a testimonial "to the continuing allure of the long linear format for expeditionary survey work." ${ }^{, 47}$ She also notes how the photograph contains evidence of the actual labour exerted by the Boundary Survey itself - the actual work of the engineers who felled trees to create the line and built the rock cairns to give it permanence. As will become evident, an immense amount of meaning and power could be transmitted in photographs that appeared to have the ability to capture evidence of work. Bell's reconnaissance survey in Athabasca, however, avoided labour. This is evident in his description of the advantages found in letting the river guide the survey:

(1) We avoid the expense of cutting the lines, which would add but little to our knowledge of the natural features of the country, and would soon be obliterated. (2) The clear space afforded by the surface of the water serves better than an artificial opening in the woods for measurements by the micrometer, which may be made as accurately as by the chain. It also admits of triangulation, which is impossible in the forest. (3) A greater distance may be surveyed per day. (4) A smaller party can do the work. (5) The canoes or boats by which the survey is carried on, also serve to convey, at the same time, the supplies of the party, and allow of a

\footnotetext{
${ }^{45}$ Zaslow, Reading the Rocks, 152.

${ }^{46}$ Bell in Geological Survey of Canada, Summary Report of Progress for 1866-69, prepared by William Logan (Ottawa: Queen's Printer, 1869), 316.

${ }^{47}$ Martha A Sandweiss, Print the Legend: Photography and the American West (New Haven and London: Yale University Press, 2002), 151.
} 
considerable quality being taken, thus enabling the work to go on continuously for a greater distance, or a longer time, without reference to the base of operations, than where everything has to be carried on men's backs. ... (7) The same measurements, which serve to determine correctly the distribution of the rock-formations, also enables us to lay down the topographical features of the country, and thus we obtain a knowledge of its geography simultaneously with that of its geology."

Within the context of this new exploratory survey method, Bell's trip on the Athabasca reflects the culmination of his new way of traversing and mapping the land, with the sleek and mobile exploratory surveyor picking up items of geographical interest along the way. His assistant, Lawson, described leaving Lac La Biche: "it was a very simple sort of an expedition. We had two buckboards and two horses. Bell drove one and I the other."49 Upon reaching Athabasca Landing, their Peterborough canoes ready to put in the water, Bell prepared to let the river-system survey itself.

The Athabasca-Mackenzie system, accordingly, almost became an actor in Bell's lecture account of his survey. He placed it amongst the "five rivers of the first class" that could be found in North America, "namely, the Mississippi, the Mackenzie, the St.

Lawrence, the Yukon, and the Nelson." ${ }^{50}$ Bell was not interested in simply mapping the rivers and landforms alone; rather, he was interested in incorporating them into Canada. In his discussion of early surveying in Australia, Paul Carter distinguishes between two different types of discovery voyages: "the explorer's desire to constitute space as a track with the surveyor's interest in regionalizing it." ${ }^{251}$ The outcome of this difference, Carter explains, is that the surveyor does more than simply claim 'I was there', but discovers how, "in a narrative of travelling, history could not be distinguished from geography.

\footnotetext{
${ }^{48}$ Bell in Summary Report of Progress for 1866-69, prepared by Logan, 316-317.

${ }^{49}$ A.C. Lawson, "Out of Beaten Paths," University of California Chronicle s.v. (1926): 61.

${ }^{50}$ Bell, "The Athabasca-Mackenzie Basin."

${ }^{51}$ Paul Carter, The Road to Botany Bay: An Exploration of Landscape and History (New York: Alfred A Knopf, 1988), 108.
} 
How, to preserve the spatiality of events, the chronicler had to invent rhetorical viewpoints." ${ }^{52}$ Bell's reconnaissance method allowed for the spontaneous development of these rhetorical points as long as he was on the river: "the following are distances, in straight lines, of the principal features in the former stretch from the junction of the Biche River: Quito River, from the west, 8 miles; Shaitaik or Pelican River, from the west, 52 miles; House River, from the east, 74 miles; the Grand Rapid, 82 miles.” Redrawing the spatial meaning of the site, from the junction of the Biche River and the Clearwater, Bell transformed the meaning of the location into a recognizable set of measurements. Bell's report on the Athabasca, represented by the distances of the reconnaissance survey as spatially narrated, was presented as a "narrative of the journey to and from the most distant point reached, with dates of arrival at the principal points and other details." 53 Entering the nineteenth century, W.J.T. Mitchell suggests that "one of the most striking features of modern culture has been the intensive, almost compulsive, collaboration between practitioners of the word and practitioners of the image. ${ }^{, 54}$ Following this, the quaint woodcut with the canoe [Plate 7] was for Bell one of those spatially rhetorical points, and therefore the implicit meanings of a canoe resting on the shores of the Athabasca must be interpreted through Bell's frame of reference. Not simply a river, the "clear space afforded by the surface of the water" looms before the surveyor's canoe - a triangulator's dream. Once finished their work here, a two-person canoe party, free from any "reference to the base of operations," can pilot their swift canoe downstream at the behest of the Athabasca conveying "at the same time, the supplies of the party." Upon

\footnotetext{
${ }_{53}^{52}$ Carter, The Road to Botany Bay, 116.

53 Part of the Basin of the Athabasca River, prepared by Bell, 5.

${ }^{54}$ W.J.T. Mitchell, ed., The Language of Images (Chicago and London: The University of Chicago Press, 1980), 1.
} 
reaching a site of geological significance, they may stop and take not only more accurate "measurements by the micrometer," but also "determine correctly the distribution of the rock formations" - craftily depicted by Bell on the far side of the river. ${ }^{55}$

Though Bell probably had his Athabasca River scene crafted from an original photograph as he had done in the past, the image failed to retain the specific codes of exploratory surveying and the meaning of Canada's mining future that were involved in its creation. Bell was unable to broach what Sandweiss calls the "powerful barrier of viewer's expectations." 56 His image of the Athabasca and plans for developing the river remained forgotten for thirty years. The artifice malleable enough to allow full play to the spaces of Bell's imagination resulted in his vision of the North being ultimately twodimensional. Maps, on the one hand, as Sherill Grace explains, "can refer to a real world ... but on the other, they can also be artistic, imaginative constructions of a world we want to be there." ${ }^{.57}$ Cartographic, rather than photographic, practices would be the first to broach the North.

\section{Mapping}

On the $28^{\text {th }}$ of October, 1881, the Winnipeg Times reported on the 'Return of Dr.

Bell's Assistant from the Northern Wilds.' After two years in the northern bush,

the geological formation of the country Mr. Cochrane was not at liberty to disclose, as it was only a matter between himself and the department, to which he has to formally report. Enough could be gleaned from him,

\footnotetext{
${ }^{55}$ Carter recommends that, "there is a temptation to make the landscape a reflex of the explorer's mind, even to speculate that in some way that what the explorer found was himself rather than anything external. ... this kind of treatment rests on dubious assumptions - both about the nature of historical space and about the nature of exploration. The explorer was not on one side with nature on the other. Rather, the two emerged as historical objects through and in terms of each other." Carter, The Road to Botany Bay, 100. ${ }^{56}$ Sandweiss, Print the Legend, 147.

${ }^{57}$ Sherill E. Grace, Canada and the Idea of North (Montreal and Kingston: McGill-Queen's University Press, 2001), 79.
} 
however, to know that the physical features of the country are exceedingly rough and largely intersected with rivers and lakes. ${ }^{58}$

The detailed information that A.S. Cochrane, an assistant topographer hired by Bell in 1877 , knew not to expose, was contained in the maps he carried with him back from the North. Bell had sent Cochrane to Lac du Brochet-Post on Reindeer Lake in 1880 to begin generating maps and gathering information about the District of Athabasca. ${ }^{59}$ The Geological Survey of Canada had been producing maps for public consumption since 1856, when Sir William Logan hired a member of the British Ordinance Survey to draft maps in order to illustrate his work. ${ }^{60}$ Topographers and cartographers were hired in increasing numbers throughout the late nineteenth century, as the need to annul the terra incognita of the far lying regions of Mackenzie, Franklin, Keewatin, and Ungava increased. Brian Harley explains that map-making must be approached, "from the premise that cartography is seldom what cartographers say it is." ${ }^{.61}$ Maps are often given a historical contingency, in which they chart the gradual unfolding of political territories or knowledge of geological formations, but always appear as a record and are not involved in the production and signification of these forms. When presented as simultaneous aids to evolution of political boundaries, they tend to assume that the shape the territory took was natural, positive, and progressive. Efforts to standardize a general 'one inch to one mile' cartographic scaling across the country could be seen as a natural step in any state's growth: "a national topographic map is a tool for self-knowledge, one that a number of countries - including France, Great Britain and the United States - have

\footnotetext{
58 "Geological Survey - Return of Dr. Bell's Assistant from the Northern Wilds," Winnipeg Times 28 October 1881: 1 .

${ }^{59}$ Robert Bell Fonds (LAC) MG29 B15 vol.16 file.76, "Correspondence," A.S. Cochrane to Robert Bell, 1880 .

${ }^{60}$ Brian Hallett, "Map Making at the Geological Survey of Canada," The Archivist 19.3 (1992): 5.

${ }^{61}$ J.B. Harley, The New Nature of Maps: Essays in the History of Cartography, ed. Paul Laxton (Baltimore: The John Hopkins University Press, 2001), 151.
} 
possessed since the eighteenth century. But it was not until the early twentieth century that Canada began its efforts to acquire one."62 This kind of isomorphic teleology, Brian Harley contends, ignores the complex of power-knowledge located in the textual map itself - the very presence of which is never so ubiquitous; it fails to inquire of the map what rules govern 'self knowledge,' and what allows for the formation and execution of these rules. ${ }^{63}$ The reason that the apparently natural occurrence of geological formations could be presented on the same map as that depicting the territories and boundaries of human political consciousness was not an a priori ability given to humankind as a signifying animal. Conversely, it was possible because "the rules of society and the rules of measurement are mutually reinforcing in the same image." 64

Logan began efforts to compile a "Geological Map of Canada and the adjacent regions" in 1854, with a prototype to be exhibited at the Universal Exposition in Paris. In 1865 , on the eve of Confederation, the 'completed' map - still far from completing the transcontinental nation - was finally unveiled to the world, receiving "international praise and recognition." ${ }^{95}$ When Bell descended the Athabasca-Mackenzie Basin into that 'hitherto unsurveyed' world, he went, in his own words, to produce a map that was "entirely original," to add the Athabasca-Mackenzie basin to the knowledge that was the nation of Canada. ${ }^{66}$ Harley reminds us that, "the surveyor, whether consciously or otherwise, replicates not just the 'environment' in some abstract sense but equally the territorial imperatives of a particular political system. $"$ "67 Bell struggled to make sense of

\footnotetext{
${ }^{62}$ Louis Cardinal, "Cartographic and Hydrographic Surveys in Canada: The Sum of the Parts," The Archivist 19.3 (1992): 8.

${ }^{63}$ Harley, The New Nature of Maps: Essays in the History of Cartography, 154.

${ }^{64}$ Harley, The New Nature of Maps: Essays in the History of Cartography, 157.

${ }^{65}$ Hallett, "Map Making at the Geological Survey of Canada," 6.

${ }^{66}$ Part of the Basin of the Athabasca River, prepared by Bell, ii.

${ }^{67}$ Harley, The New Nature of Maps: Essays in the History of Cartography, 54.
} 
the landscape he traversed, in the process mapping the spatial meaning and the future of the region. Laying out the bearings of distance from one point to another not only inscribed a cartographic system on the landscape, thus turning it two dimensional, but also setting a stage for future progress. Distances would be conquered, railways would be constructed and oil would be retrieved.

Progressive assumptions were based on the Enlightenment premise that a preexisting reality would be exhumed in progressively greater detail with each successive advance in scientific representation. Bell indeed claimed that, "in using the term Athabaska-Mackenzie for our great northern river, I follow the Rev. Father Petitot, the zealous missionary, who has made extensive explorations and published an elaborate map of the region." The relationship between the GSC officer and previous explorers was as metaphorical as the meaning of the land itself. The progressive project of mapping still had to overcome the hostile 'Barren Lands,' described by Bell as

the name given to the vast triangular area lying between Great Bear and Great Slave lake on the west Hudson's Bay on the east and the Artic Sea on the north. This region has a generally level character or at least is nowhere mountainous. It is almost treeless, the forest dying out along its southwestern border. In some places it is rocky bearing nothing but cariboo moss, but there are great tracts with a hard, gravely sand and bouldery surface. ${ }^{68}$

The Mackenzie Basin, now fringed on the east by inhospitable 'Barren Ground', was on the west bounded by "the Rocky Mountains, as you are aware, [which] become lower and lower in going northward and finally die down to the seabed on reaching the Arctic Ocean," the latter thus forming a northern boundary. ${ }^{69}$ His description formally frames the Mackenzie as a space open and inviting to metropolitan interest from the south, the

\footnotetext{
${ }^{68}$ Bell, "The Athabasca-Mackenzie Basin."

${ }^{69}$ Bell, "The Athabasca-Mackenzie Basin."
} 
northern portion of a depression running "through the centre of the continent, [that] embraces most of the fertile lands of North America." ${ }^{70}$ Bell affirmed that, like the Mississippi, "the banks of the Mackenzie are clothed with timber to the very mouth.",71

The reason Cochrane could not divulge his knowledge of the North was that the discursive assemblage and exhibition of maps took place in Ottawa. Upon returning from the North, Bell paired his maps and track surveys with those of Cochrane. Part of the Athabasca survey's information went into a map by Bell appearing as the "Northern Limits of the Principle Forest Trees of the Dominion of Canada." During 1883, Bell's map was hung, alongside one by Survey staff member George Mercer Dawson and a biological display by John Macoun, in a locked glass-case within the 'News Room,' a space in the Survey's office on Sussex St. where newspaper people could come and report on the maps of the day. ${ }^{72}$ That same year, a flash conflict arose between Bell and Selwyn when the former accused the latter of breaking the lock on the glass case and moving the Forest Distribution map into a case in the corner of the room, away from the central display. Macoun was quickly able to calm the situation, in the process revealing that the cleaning staff had likely moved the map and that Bell may have been something of an alarmist. The short argument nonetheless explains the cultural relevance maps possessed during the $1880 \mathrm{~s}$, as both producers and targets of power-knowledge in a performance enacted by the GSC. Later, Bell was enraged to learn that Selwyn had pasted over his assertion below the map that treelines represented "unquestioned fact"

\footnotetext{
${ }^{70}$ Bell, "The Athabasca-Mackenzie Basin."

${ }^{71}$ Bell, "The Athabasca-Mackenzie Basin."

${ }^{72}$ Robert Bell Fonds (LAC) MG29 B15Vol.26 file.47, "Correspondence," John Macoun to Robert Bell, 1884.
} 
with a piece of white paper reading "the tree lines-are mostly from personal knowledge." 73 [Plate 11]

A further grievance erupted when Selwyn edited Bell's map of the mouth of the Churchill River on Hudson Bay, questioning at the same time Bell's veracity and impugning his scientific credibility. In challenging Bell, Selwyn had challenged the map and the assumption "that the objects in the world to be mapped are real and objective, and that they enjoy an existence independent of the cartographer; that their reality can be expressed in mathematical terms; that systematic observation and measurement offer the only route to cartographic truth; and that this truth can be independently verified."74 Bell's retort was to use the Senate Review of 1884 to accuse Selwyn of being unpatriotic. $^{75}$ According to Bell, Selwyn, born British, did not understand Canadian ways nor did he have any familiarity with Canada. In rejecting Selwyn, Bell rejected the legitimacy of a metropole across the Atlantic. He viewed Selwyn's challenge of his map as a reassertion of the stifling presence of an old empire: one that questioned the idea of Canada and the expansion of the new Dominion as a colonial network in its own right, with Ottawa at the centre of radiating spheres of metropolitan influence.

Bell presented his initial map of 1882 as a nation-building exercise in itself, claiming that the map was drawn from the common ground of a utilitarian assemblage of knowledges: information came from the $\mathrm{HBC}$ post managers

and from the data furnished by the accounts and maps of the different scientific travellers who have penetrated these regions. In the more southern regions, many details have been obtained from lumbermen and

\footnotetext{
${ }^{73}$ Robert Bell Fonds (LAC) MG29 B15Vol.26 file.47, "Correspondence," John Macoun to Robert Bell, 1884.

${ }_{75}^{74}$ Harley, The New Nature of Maps: Essays in the History of Cartography, 154.

${ }^{75}$ Zaslow, Reading the Rocks, 139.
} 


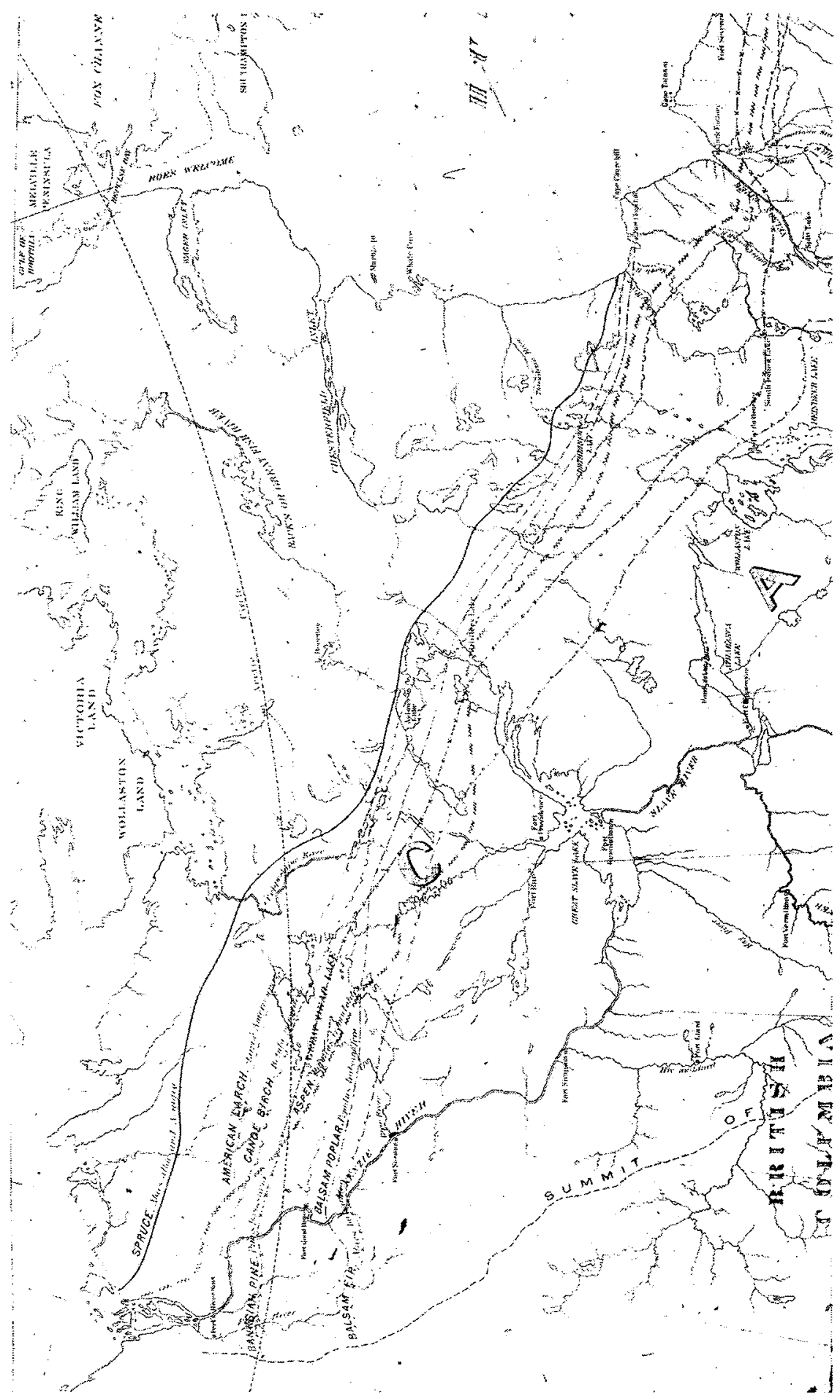

Plate 11: Map Shewing the General Northern Limits of the Principle Forest Trees of the Dominion of Canada [the quarter-section shown here contains the disputed area and a large portion of the sub-Arctic North]

Source: Robert Bell, The Geographical Distribution of the Forest Trees of Canada (Ottawa: Gazette Printing Company, 1882) inset. 
botanists which have helped to determine the lines with great accuracy in certain localities. $^{76}$

In this respect, the map formed an essential pre-text of power to the knowledge of land and landscape that photography would eventually assert (see Chapter 5). Bell presented a vision of Canada where scientists would take the egalitarian vision of merchants, labourers, and explorers alike to transform their pursuits into the gradual mapping of a transcontinental nation.

\section{The Future of the North}

Paul Carter writes of cartography that, "it was not by discovering novelties but by ordering them, rendering them conceptually and culturally visible, that the great work of colonization went ahead. It was the method of giving objects great and small a place in the world, the picturesque logic of connection and contrast, that ensured they could never be lost again or overlooked." ${ }^{, 77}$ In a passage similar to Carter's, Joan Schwartz tells us that photographs are:

a pool of visual facts, but also as symbols of imperial expansion, colonial development, commercial enterprise, military might, and scientific knowledge, these mutually-held visual images contributed to national identity, stimulated patriotic effort and reinforced one's sense of place in the world. As an instrument of cultural imperialism, the photograph helped to establish and affirm identity. ${ }^{78}$

Carter's and Schwartz's interpretations of the power of representation are incredibly similar. However, although wood engravings and maps helped Ottawa envision what the North might hold for the future of the country, photographic images were bound with another kind of understanding, and another, narrative, kind of seeing. Martha Sandweiss

\footnotetext{
${ }^{76}$ Robert Bell, The Geographical Distribution of the Forest Trees of Canada (Ottawa: Gazette Printing Company, 1882), 3.

${ }^{77}$ Carter, The Road to Botany Bay, 128.

${ }^{78}$ Joan M. Schwartz, "The Geography Lesson: Photographs and the Construction of Imaginative Geographies," Journal of Historical Geography 22.1 (1996): 30-31.
} 
evokes this narrative vision, explaining that nineteenth-century American photographers "thought of themselves as storytellers and had little faith in the descriptive usefulness of a single image." ${ }^{79}$ Sandweiss has shown that photographers developed images that would intentionally 'resound' with larger metanarratives about the subject matter they dealt with. In America, Natives portrayed as threatening and warlike during the 1860s began to be shown as peaceable and diminutive towards the end of the century, as the 'vanishing race' theory explained the west as now 'open' to U.S. expansion. Photographers employed the narrative form to reinforce their "beliefs and experiences" with a tangible structure. ${ }^{80}$

The later survey work of the survey geologist, R.G. McConnell, illustrates what historians of space may make of Sandweiss's point. McConnell slowly explored the Athabasca during 1890, making note of the geomorphologic landscape. Like Bell, McConnell travelled at the will of the river and described its gradual cut northward into the sandstone layers that cradled the Mackenzie Basin. At the rapids 159 miles north of Athabasca Landing, McConnell saw that, "at the head of the Grand Rapids about 200 feet of the Grand Rapids sandstone is exposed." miles below the Grand Rapids at Pt. La Biche ... the full thickness of the Grand Rapids sandstone (300 feet) is exposed at this point." ${ }^{92}$ McConnell meticulously recorded the height of various strata of limestone. Tracing it in horizontal diagrams he explained the age of the rock and was able to conclude what could be oil producing. [Plate 12]

\footnotetext{
${ }^{79}$ Martha A Sandweiss, "Undecisive Moments: The Narrative Tradition in Western Photography," in Photography in Nineteenth-Century America, ed. Martha A Sandweiss (Fort Worth and New York: Amon Carter Museum, H.N. Abrams, 1991), 99.

${ }^{80}$ Sandweiss, "Undecisive Moments," 99.

${ }^{81}$ Geological Survey of Canada, Report on a Portion of the District of Athabasca Comprising the Country between Peace River and the Athabasca River North of Lesser Slave Lake, prepared by R.G. McConnell (Ottawa: Queen's Printer, 1893), 29.

${ }^{82}$ Report on a Portion of the District of Athabasca, prepared by McConnell, 29.
} 


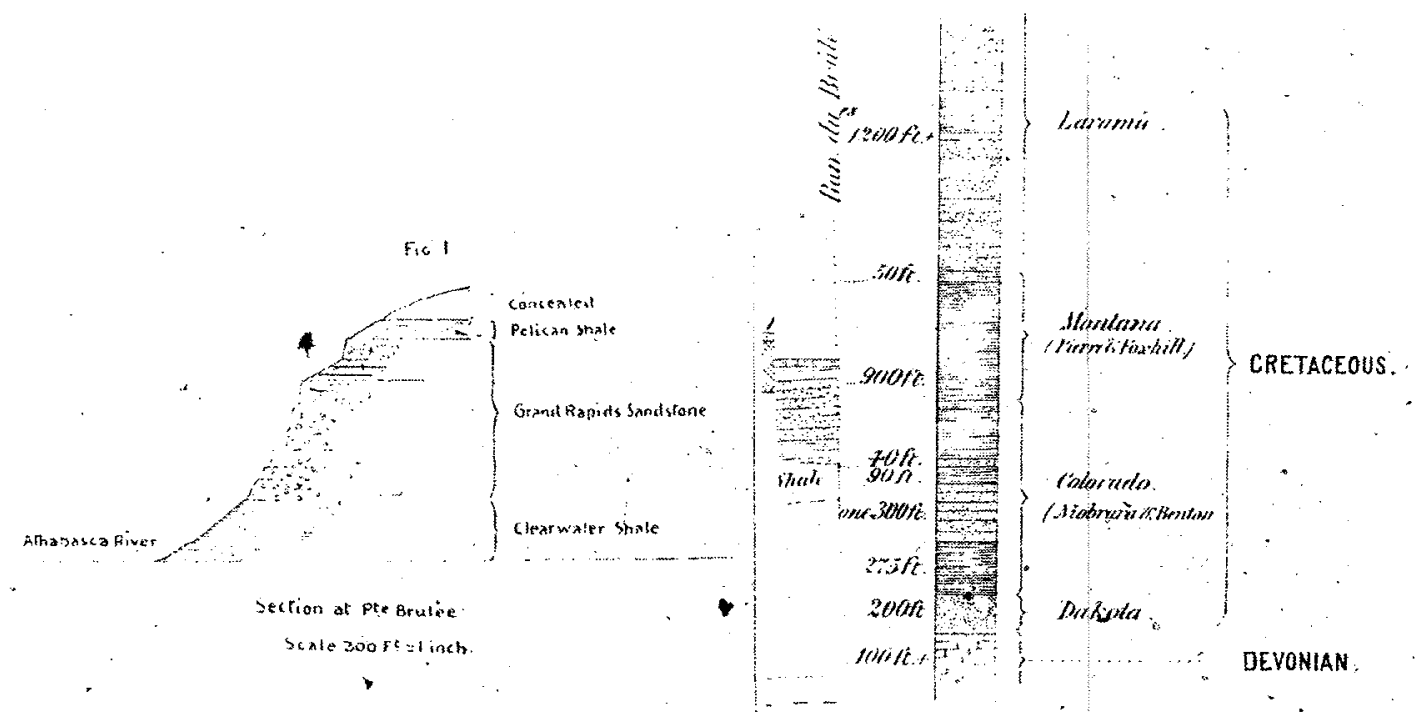

\section{Plate 12: [R.G. McConnell's Sandstone Diagrams]}

Source: Geological Survey of Canada, Report on a Portion of the District of Athabasca Comprising the Country between Peace River and the Athabasca River North of Lesser Slave Lake, prepared by R.G. McConnell (Ottawa: Queen's Printer, 1893), 30. 
Bell had already identified that the pressure of Devonian limestone deep beneath the Cretaceous beds as the source of the region's petroleum; McConnell was attempting to picture it. The voyage of $1889-90$ resulted in an album containing 37 prints added to the Survey's library. ${ }^{83}$ Employing Sandweiss's assertion that photographic narratives are identifiable, McConnell's album may be read as reflecting a larger structural concept of the Athabasca as a potential resource vault. Though McConnell was much more hesitant than Bell, he did believe that "the agricultural capabilities of portions of the PeaceAthabasca district are promising, but have not yet been thoroughly tested," ${ }^{, 84}$ and that tar sands would, "in the future, be profitably utilized for various purposes, when this region is reached by railways." 85 Though McConnell could read the rocks to interpret the future of the nation, his 'Nodules in Grand Rapids Sandstone,' was unable to narrate it, and hence the image was distant from grand visions of progress and remains as specialized as the language of the scientific report. [Plate 13]

Elaborating on nineteenth-century photographers, Sandweiss informs us that, "they transformed photography into a narrative storytelling medium that could describe events stretching across space and time, but in doing so they strained against the technical and conceptual limitations of a medium that could capture only a particular moment and place. ${ }^{.86}$ The Athabasca itself, as it guided McConnell's geological eye, again, resisted the static moment of a photograph. It also resisted McConnell's particular 'way of seeing' sensitive to space and time, one best expressed in his description of the Mackenzie basin's rich oil futures as "almost co-extensive with that of the valley itself,"

\footnotetext{
${ }^{83}$ R.G. McConnell, Athabasca Album (LAC) 1970-088 NPC

${ }^{84}$ Report on a Portion of the District of Athabasca, prepared by McConnell, 8.

85 Report on a Portion of the District of Athabasca, prepared by McConnell, 65 .

${ }^{86}$ Sandweiss, "Undecisive Moments," 105.
} 


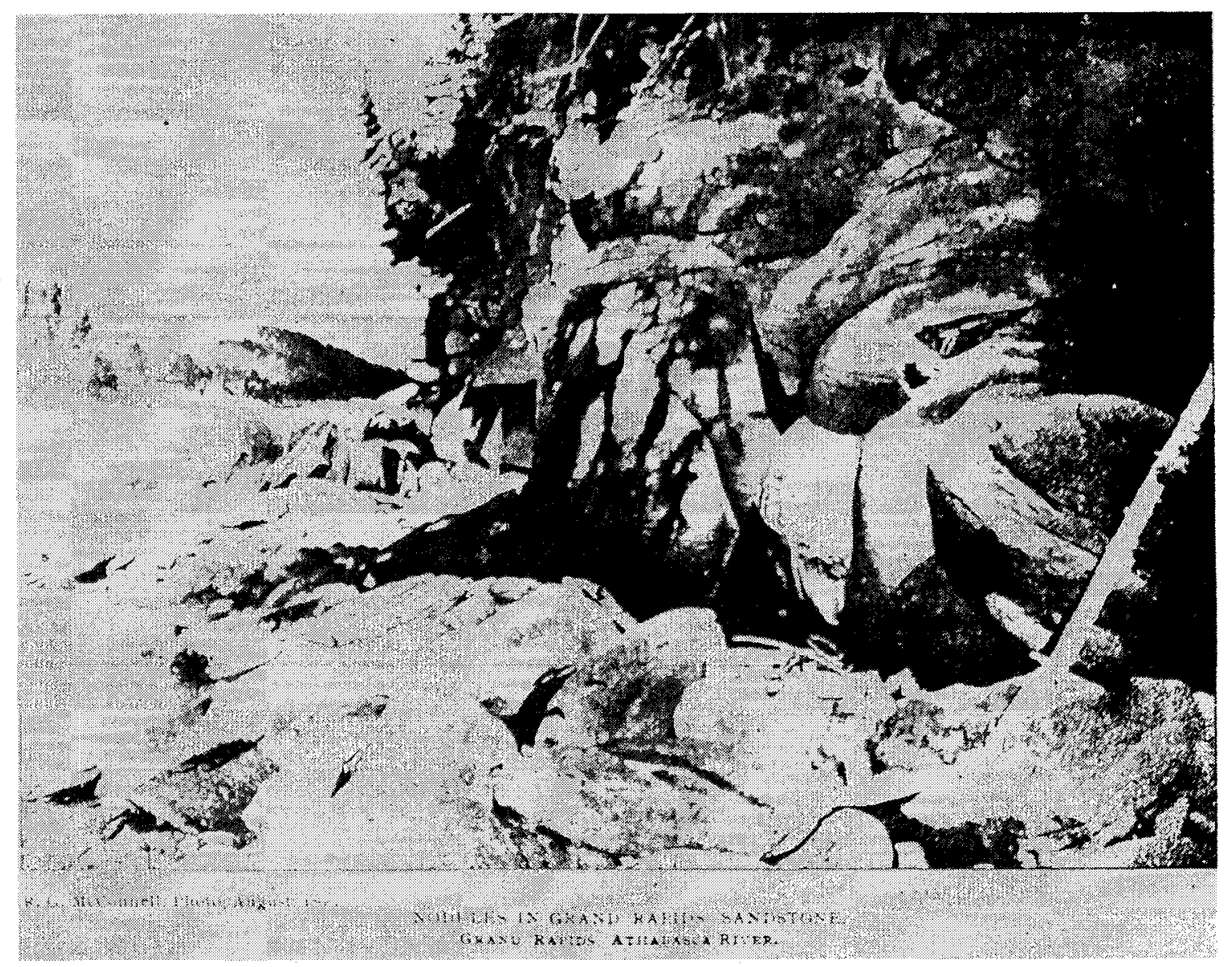

\section{Plate 13: Nodules in Grand Rapids Sandstone}

Source: Geological Survey of Canada, Report on a Portion of the District of Athabasca Comprising the Country between Peace River and the Athabasca River North of Lesser Slave Lake, prepared by R.G. McConnell (Ottawa:

Queen's Printer, 1893), 34. 


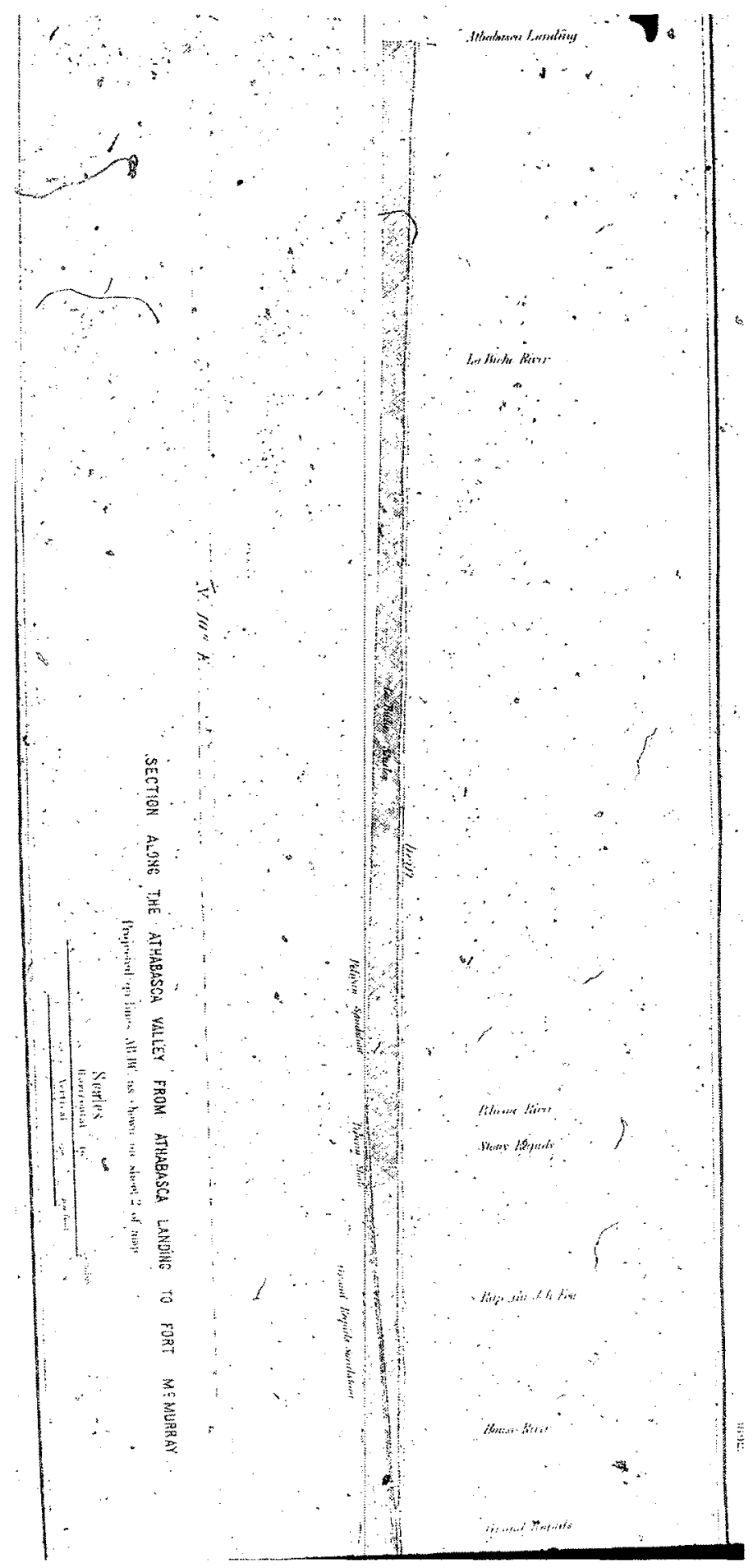

Plate 14: Section along the Athabasca Valley [Part I]

Source: Source: Geological Survey of Canada, Report on a Portion of the District of Athabasca Comprising the Country between Peace River and the Athabasca River North of Lesser Slave Lake, prepared by R.G. McConnell (Ottawa: Queen's Printer, 1893), insert. 


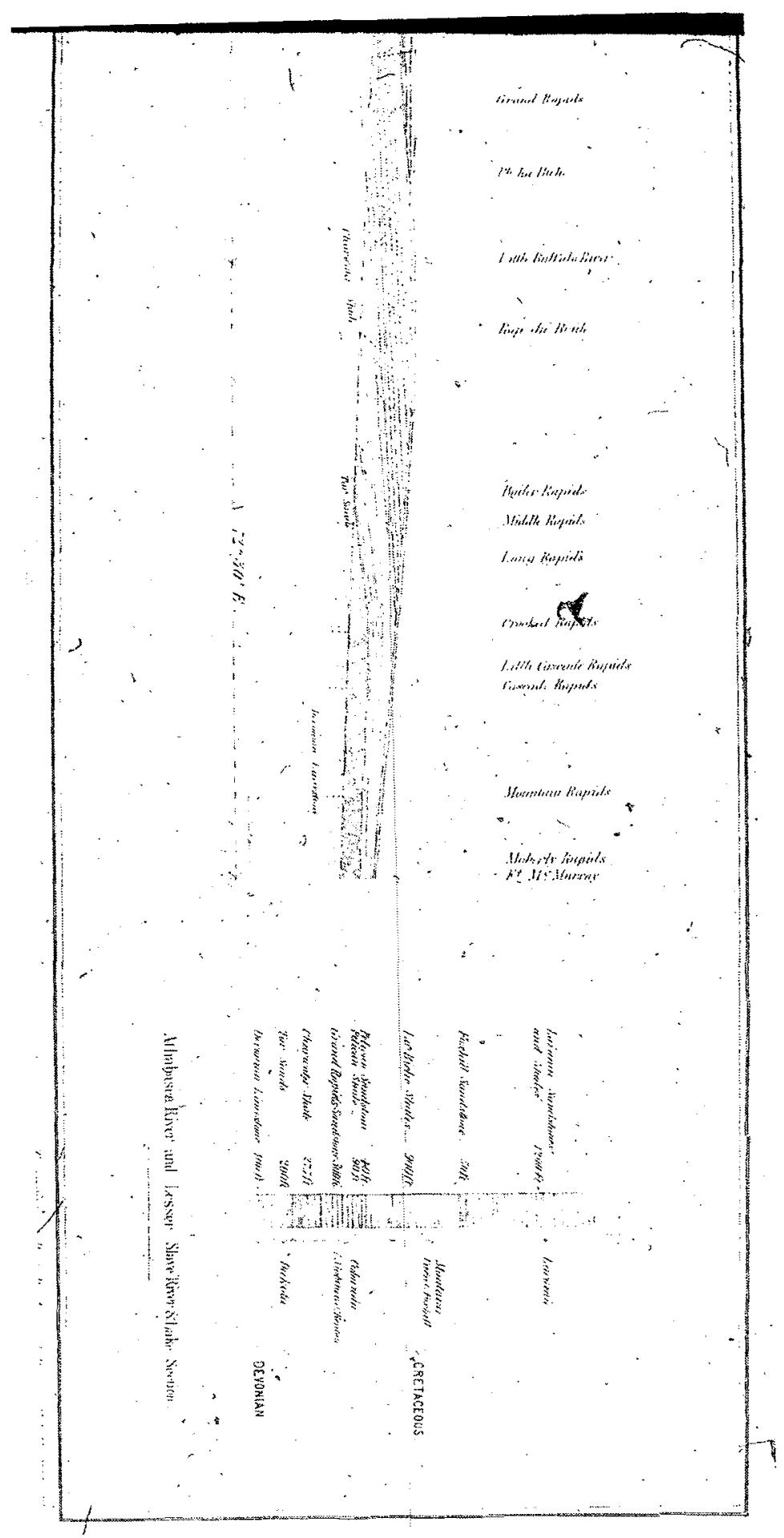

\section{Plate 15: Section along the Athabasca Valley [Part II]}

Source: Source: Geological Survey of Canada, Report on a Portion of the District of Athabasca Comprising the Country between Peace River and the Athabasca River North of Lesser Slave Lake, prepared by R.G. McConnell (Ottawa: Queen's Printer, 1893), insert. 
due to the prevalence of oil-bearing shale. ${ }^{87}$ He turned to alternative methods of narrating the river that photography could not accomplish, such as the topographical sideview of the riverbank to show how, "In ascending the Athabasca, the Tar sands are overlaid at Boiler Rapid by a cover of shales sufficient to prevent the oil from rising to the surface, and in ascending the river, this cover gradually thickens." ${ }^{\text {"P }}$ [Plates $14 \& 15$ ] McConnell's sketches communicated what the realistic images could not, the coexistence of the downstream northward motion of his voyage, the river, and the future of Canada.

\section{Conclusion - Broken Lines}

In an 1890 lecture that would be published the same year, George Mercer Dawson addressed the Ottawa Field-Naturalists' Association. Perhaps suggesting the inability of photography to capture the Far North, he lamented of "The Larger Unexplored Regions of Canada," and regretted how there were so many "persons by whom the region has been traversed, but who have been un-provided with instruments of any kind and whose knowledge of the country has been incidentally obtained." 89 Dawson, a member of the Geological Survey of Canada since 1875, certainly felt that this knowledge was valuable, and even expressed his conviction that symbolically 'broken lines' be used to represent such knowledge on the Survey's maps. ${ }^{90}$ Dawson maintained that insufficient knowledge stood in the way of Canada's social and economic progress, on the cusp of which was the noble Survey:

The tendency of our time is all in the direction of laying bare to inspection and open to exploitation, all parts, however remote, of this

\footnotetext{
${ }^{87}$ Geological Survey of Canada, Report on an Exploration in the Yukon and Mackenzie Basins, N.W.T., prepared by R.G. McConnell (Montreal: William Foster Brown \& Co., 1891), 32.

88 Report on a Portion of the District of Athabasca, prepared by McConnell, 65 .

${ }^{89}$ G.M. Dawson, On Some of the Larger Unexplored Regions of Canada. A Paper Presented at the Ottawa Field-Naturalists' Association (Ottawa: Ottawa Naturalist, 1890), 2.

${ }^{90}$ Dawson, On Some of the Larger Unexplored Regions of Canada, 3.
} 
comparatively small world in which we live, and though the explorer himself may be impelled by a certain romanticism in overcoming difficulties or even dangers met with in the execution of his task, his steps are surely and closely followed by the trader, the lumberer, or the agriculturist, and not long after these comes the builder of railways with his iron road. ${ }^{91}$

The Survey would not lose hope of bringing the Athabasca-Mackenzie basin inside of its metropolitan sphere of Ottawa, but the place was clearly outside the boundaries of sufficiently explored territory indicated on the map Dawson used to illustrate his lecture. Though the map was now firmly entrenched in the experience of northern travel and the photograph was beginning its ascent, the North was, according to Dawson, still as of yet, 'unknowable.'

During the 1890 s a new kind of explorer began to travel down the Athabasca in increasing numbers: the self-aggrandizing late-Victorian 'sportsman': part-naturalist, part-hunter, and part-photographer. Unlike the specialized reports of the GSC, their record is in the bound pages of photographically illustrated adventure novels, all of which, queued with fashion, would come equipped with a map for tracing "the author's route." It was through adventurers such as Warburton Pike, Caspar Whitney, and Frank Russell, that the matters of structure and perception began to take a new shape. They exploited the duality of the photograph - the 'unknowable' realm of the sportsman was bound to the 'knowable' world of the scientist and naturalist. And, as the North reached the zenith of its romantic historicist horizon - signalled by the HBC's opening of the North to commercial interest - the fur trade and Edmonton's role in the North became apparent. As Boas insisted it should be, the quest began to know the North before what

${ }^{91}$ Dawson, On Some of the Larger Unexplored Regions of Canada, 1. 
was what perceived as the inevitable changes brought by modernity changed forever the place and altered the Natives who lived in it. 


\section{Chapter 3: Illustrated Adventure Stories, 1890-1900}

\section{Introduction - The Barren Lands of the Far North}

In 1892, four years after his return from the Far North, Warburton Pike published his adventure novel, The Barren Ground of Northern Canada. George Mercer Dawson's map and lecture, "On Some of the Larger Unexplored Regions of Canada," were included as an appendix to the book. [Plate 16] Pike celebrated Dawson's map, explaining that it showed, "more plainly than any words of mine could tell how much yet remains to be done before this great portion of the British Empire is known as it ought to be." The renowned English sportsman continued by expounding on the motivation behind his voyage:

In talking with officers of the Hudson's Bay Company, many of whom had been stationed for long periods in the Athabasca and Mackenzie River districts, I had often heard of a strange animal, a relic of an earlier age, that was still to be found roaming the Barren Ground, the vast desert that lies between Hudson's Bay, the eastern ends of the three great lakes of the North, and the Arctic Sea. This animal was the Musk-ox, but my informants could tell me nothing from personal experience, and all that was known on the subject had been gathered from Indian report. Once or twice some enthusiastic sportsman had made the attempt to reach the land of the Musk-ox, but had never succeeded in carrying out his object; specimens had been secured by the officers of the various Arctic expeditions, but no one had ever seen much of these animals or of the methods of hunting them employed by the Northern Indians. ${ }^{2}$

The geographical dimensions of Pike's journey rested not in the creation of the 'Barren Lands,' or in the construction of the North, but in their erasure from time and space and into the same definition of 'unexploredness' that Dawson lamented. Conjuring images of

\footnotetext{
${ }^{1}$ Warburton Pike, The Barren Ground of Northern Canada (1892; New York: E.P. Dutton \& Company, 1917), 303.

${ }^{2}$ Pike, Barren Ground, v-vi.
} 


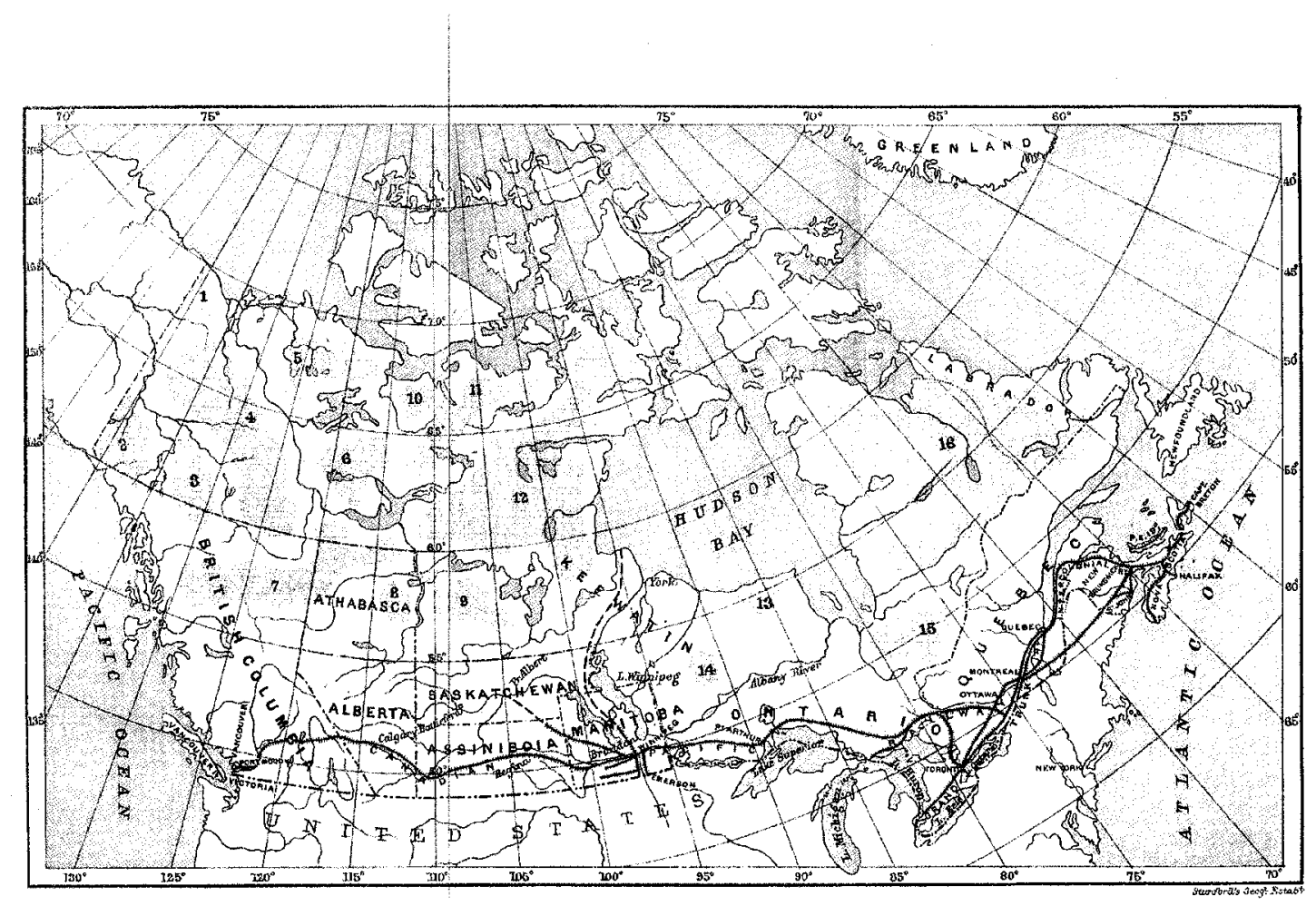

DOMINION OF CANAADA.. OUTHIIE MAP SHEWING THE LARGER UNEXPLOBED AREAS, 1890. (To illustrate paper by George MTDewsinn)

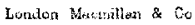

\section{Plate 16: Dominion of Canada Outline Map Showing the Larger Unexplored} Areas

Source: G.M. Dawson in Warburton Pike, The Barren Ground of Northern Canada (London and New York: MacMillan, 1892), inset. 
untouched space, described as "a great blank on the map" by one columnist, ${ }^{3}$ an impoverished desert wasteland appeared in the Canadian Arctic. Pike's 'vast desert' was mimicked by J.B. Tyrell who recognized it as terra incognita, an "entire territory [about which] less was known than of the remotest districts of 'Darkest Africa.",4 The only thing inhabiting these remote reaches of the earth, the musk-ox, signified above all else, the past-ness of the very place: somewhere modernity could not touch. Although the Natives had seen the creatures, they lacked the instrumentation to record the experience or to fulfil the Victorian lust for 'securing specimens.' Unlike white knowledge, Native ways of knowing were seen as ephemeral, imperfect and furthermore, according to Pike, did little to distinguish between hunter and quarry. In a characteristic summoning of 'civilized' images of race and class to anchor his explanation of the North, Pike explained the difference between his 'half-blood' guide King Beaulieu and a full-blooded Loucheaux by describing the former as, "a mixture of a very simple child and a German Jew; all the lack of reason of the one combined with the greed of the other, and a sort of low cunning more like that of an animal than a human being." 5

\section{'The Myth of Empty Land'}

Postcolonial scholar Anne McClintock theorizes that, "The myth of the virgin land is also the myth of the empty land, involving both a gender and a racial dispossession." McClintock's provocative statement suggests that nineteenth-century spaces considered empty, like the 'Barren Lands' east of the Mackenzie, contained

\footnotetext{
3 "Crossed Barren Lands," Boston Daily Globe 19 May 1895: 18.

${ }^{4}$ J.W. Tyrrell, Across the Sub-Arctics of Canada: A Journey of 3,200 Miles by Canoe and Snowshoe through the Barren Lands (Toronto: William Briggs, 1897), 7.

${ }^{5}$ Pike, Barren Ground, 23.

${ }^{6}$ Anne McClintock, Imperial Leather: Race, Gender and Sexuality in the Colonial Conquest (London and New York: Routledge, 1995), 30.
} 
historical connotations of sexuality and desire. The relationship between the modern city and the empty hinterland, thus broadly conceived by McClintock, is structured by connotations of a powerful, male, metropolitan centre penetrating the 'virgin' and passive female hinterland, inseminating the latter with "history, language and reason." She adds that the historical-geographical underpinning of this colonizing allusion must be acknowledged. Movement into "virgin' land "reveals a contradiction, for the journey is figured as proceeding forward in geographical space but backward in historical time, to what is figured as a prehistoric zone of racial and gender difference." ${ }^{.7}$ McClintock calls the combination of historical and geographic imaginings the construction of 'anachronistic space.' Aboriginal inhabitants of the North who found themselves subjects before the camera during the 1890 s were pictured deep within these assumptions for a metropolitan audience, existing "in a permanently anterior time within the geographic space of the modern empire as anachronistic humans, atavistic, irrational, bereft of human agency - the living embodiment of the archaic "primitive."'8

During the last decade of the nineteenth century, a complicated set of organizing principles began to operate on and within the Athabasca and Mackenzie districts as authentically 'anachronistic space' became harder for Euro-Canadian males to attain. Richard Phillips has described this period as 'the end of geography,' an age when the few remaining untraversed parts of the world achieved paramount importance: "the late nineteenth-century scramble to map was also a scramble to colonise and consolidate imperial power." 9 Photography was not absent from this process of imagining imperial

\footnotetext{
${ }^{7}$ McClintock, Imperial Leather: Race, Gender and Sexuality in the Colonial Conquest, 30.

${ }^{8}$ McClintock, Imperial Leather: Race, Gender and Sexuality in the Colonial Conquest, 30.

${ }^{9}$ Richard Phillips, Mapping Men and Empire: A Geography of Adventure (London and New York: Routledge, 1997), 7.
} 
geography. James Ryan points out that as a technology it provided a unique opportunity for "creating a parallel Empire within a range of discourses including science, art, commerce and government."10

None of the following sojourners openly espoused such lofty goals, but travelled to the North because of their own aspirations. The adventuring Londoner, Warburton Pike, the American anthropologist Frank Russell, and the New York journalist Caspar Whitney all found the apogee of that transformative masculinity in a voyage to the Barren Grounds of northern Canada in order to live amongst the Natives and kill the ancient musk-ox. They brought with them cameras, guns, and their own mythology.

Investigating their voyages reveals the integral and integrated role of photography in the production and reproduction of the North as an imagined 'other' and passive subject of metropolitan civilization and colonial control.

\section{Antimodernism}

James Ryan notes the cultural salience of Victorian hunters as, "still remembered, variously, as heroic adventurers, intrepid explorers, accomplished naturalists and, perhaps ironically, pioneers of conservation."11 As celebrities in the late Victorian period, they acted as representatives of the metropole when they voyaged into the North seeking 'real' experiences the city was unable to offer. Expectations of reality often guided and shaped experiences in a way that became popular manifestations of the mentality that historians have broadly termed 'antimodernism.' According to Lynda Jessup, antimodernism is a cultural experience derived from the experience of modernity; it is "the pervasive sense of loss that often coexisted in the decades around the turn of the century along with an

\footnotetext{
${ }^{10}$ Ryan, Picturing Empire, 26.

${ }^{11}$ Ryan, Picturing Empire, 99.
} 
enthusiasm for modernization and material progress."12 Alternatively, Ian McKay presents antimodernism as the ideological by-product of a search for experience: "an intensely individualistic thirst for an existence released from the iron cage of modernity into a world re-enchanted by history, nature, and the mysterious." 13

In the same breath that they touted the achievements of civilization, men such as Pike, Whitney, and Russell represented a widespread crisis that 'masculinity' was perceived to be facing in becoming 'feminized' by the plush luxurious surroundings of the city. Caspar Whitney explained how he sought the Far North, "that I might for a time escape the hum and routine sordidness of the city, and breathe air which was not surcharged with convention and civilization." 14 To his dismay, Whitney's first shock was elicited in discovering that Edmonton had an electric light station: "I had hoped Edmonton would prove to be a bit untamed and picturesque ... there were none of those blood-stirring nights in town such as we used to have on our own frontier; ... no cowboys to ride into saloons and shoot out the lights." ${ }^{\prime 5}$ Warburton Pike expressed his own sentiments more philosophically:

Close at hand are all the luxuries that only ultra-civilization can give, and these luxuries are to be obtained by the simple method of handing over an adequate number of coins of the realm; there is no necessity to shoulder your gun and tramp many weary miles on snow-shoes before you get even a sight of your dinner in its raw state. But surely we carry this civilization too far, and are in danger of warping our natural instincts by too close observance of the rules that some mysterious force obliges us to follow when we herd together in big cities. Very emblematical of this warping process are the shiny black boots into which squeeze our feet when we throw away the moccasin of freedom;

\footnotetext{
${ }^{12}$ Lynda Jessup, ed., Antimodernism and the Artistic Experience: Policing the Boundaries of Modernity (Toronto: University of Toronto Press, 2001), 3.

${ }^{13}$ Ian McKay, The Quest of the Folk: Antimodernism and Cultural Selection in Twentieth-Century Nova Scotia (Montreal and Kingston: McGill-Queen's University Pres, 1994), xv.

${ }^{14}$ Caspar Whitney, On Snow-Shoes to the Barren Grounds: Twenty-Eight Hundred Miles after Musk-Oxen and Woodbison (New York: Harper \& Brothers Publishers, 1896), 2.

${ }^{15}$ Whitney, On Snow-Shoes, 12-13.
} 
as they gall and pinch the unaccustomed foot, so does the dread of our friends' opinion gall and pinch our minds till they become narrow, out of shape, and unable to discriminate between reality and semblance. ${ }^{16}$

The fear of losing the ability to distinguish between reality and semblance could be assuaged by acquiring 'authentic' experiences. Wearing the "moccasin of freedom" meant stepping out of time and into the primitive, 'timeless' life of the savage hunter of musk-ox, only found in the unknown barren desert of northern Canada. To antimodernist hunters trying to capture a disappearing past and forge their primitive masculine self, the camera provided an incredibly functional tool of recording, circulating, and constructing experience. Together, the camera and the hunting rifle would not only capture the North, but would function in establishing the binary relations between past and present, masculine and feminine, white and 'other,' authentic and inauthentic, civilized and primitive. Ultimately this fashioned the representational underpinnings that must be accounted for in the "matters of structure and perception" that secure the economics of the frontier-metropole bind.

\section{Shooting Pictures}

Carol Armstrong explains that photographs of specific places were the first to be incorporated into popular books during the mid nineteenth century. ${ }^{17}$ The reader of a narrative account could 'trace' the voyage of the protagonist along the book's included map, and have the adventure signposted by numerous photographs guaranteeing the existence of the place or the traveller's arrival there. Armstrong argues that the dialectic between image and text in travel narratives cannot be understood without examining the "subideological workings of its positivism on which all of its ideological statements

\footnotetext{
${ }^{16}$ Pike, Barren Ground, 299.

${ }^{17}$ Carol Armstrong, Scenes in a Library: Reading the Photograph in the Book, 1843-1875 (Cambridge, London: The MIT Press, 1998), 277.
} 
rest." ${ }^{\prime 18}$ Positivism, as a school, believed that classificatory systems of knowledge should be derived from nature and not made to fit human creation. Because the camera was understood to be a 'mirror of nature' by Victorian audiences, it seemed to be the proper way of anthropological recording, natural history gathering, and exploration; all essential aspects of the Victorian model sportsman. ${ }^{19}$ When employed as a recording device engaging with colonial space, however, the camera went from an indispensable companion to what Elizabeth Childs describes as "a crucial element of control and visual privilege." ${ }^{20}$ Schwartz and Ryan assert that photography must be acknowledged as an powerful tool for 'imagining' geography and picturing place: "made practicable at a time when vision and knowledge came to be inextricably linked, the photograph offered a means of observing, describing, studying, ordering, classifying, and thereby, knowing the world. $" 21$

James Ryan suggests that many hunting photographers justified their excessive killing in the name of natural science and gaining specimens, gathering knowledge in general. $^{22}$ Caspar Whitney, for example, having cornered a musk-ox and stunned it with a non-lethal shot through the head, was torn between gaining valuable knowledge of 'natural science' and killing his quarry. "I determined experimenting on the strength of the boss," he explained as he fired a bullet into the animal's horns:

Then to see if the brain could be reached by penetrating the skull just at the lower edge of the boss, I fired a second time, but though my bullet crashed through his forehead and blood gushed out of his mouth and

\footnotetext{
${ }^{18}$ Armstrong, Scenes in a Library, 280.

${ }^{19}$ Ryan, Picturing Empire, 99-139.

${ }^{20}$ Elizabeth C. Childs, "The Colonial Lens: Gauguin, Primitivism, and Photography in the Fin De Siècle," in Antimodernism and Artistic Experience: Policing the Boundaries of Modernity, ed. Lynda Jessup (Toronto: University of Toronto Press, 2001), 52.

${ }^{21}$ Joan M. Schwartz and James R. Ryan, eds., Picturing Place: Photography and the Geographical Imagination (London: I.B. Tauris, 2003), 8.

${ }^{22}$ Ryan, Picturing Empire, 107.
} 
nostrils, I had evidently not reached the brain, as he still stood on his feet. ... I regret now I did not try the effect of a bullet sent directly into the crevice, for my subsequent dissection of a musk-ox head rather convinced me the brain could be reached if a bullet was sent home exactly on this spot. ${ }^{23}$

In Whitney's rendition the gun becomes an instrument of vision. In a brutal dissection of a live musk-ox, Whitney fulfilled with his gun what his camera had been unable to achieve. "He had stood up fully fifteen minutes," the hunter explained, "and had my camera been at hand, instead of in a sledge several miles away, I could have secured a splendid photograph. But one cannot carry both a rifle and camera and chase musk-oxen, and I wished to finish with my rifle before I began with my camera."24

Whitney's understanding of hunting as a process of knowledge-gathering akin to image-making was also characteristic of the binary explanations travellers brought to the North. Whereas white, civilized hunting served a purpose, adventurers often lamented what they perceived as the Native "stupid love of killing" and "improvident waste." Frank Russell's observation that "they kill nearly every living thing which it is in their power to destroy, without mercy or discrimination," led him to label the North as "a country of death." 25 The Natives, according to the hunters, were causing their own demise and the ability to locate primitive masculinity among them in the Barren Lands was disappearing in turn. In his acknowledgement that the caribou herds of the North were being depleted, Pike claimed "it is absurd to say that the white man is killing them off ... and the Indians are themselves dying out year by year." ${ }^{26}$ A New York Times plea

\footnotetext{
${ }^{23}$ Whitney, On Snow-Shoes, 247-8.

${ }^{24}$ Whitney, On Snow-Shoes, 249.

${ }^{25}$ Frank Russell, Explorations in the Far North: Being the Report of an Expedition under the Auspices of the University of Iowa During the Years 1892, '93, and'94 (lowa City: University of lowa, 1898), 223.

${ }^{26}$ Pike, Barren Ground, 50.
} 
for musk-ox conservation echoed that, "the rifle in the hands of the Indians has told on their numbers with fearful effect."27

Finis Dunaway has shown that hunting, photography, and the imaginary concepts of masculinity and the fear of a disappearing primitive world are interconnected. Late nineteenth-century men viewed the camera as a 'technology of memory', intimately connected to a possibility of capturing and retaining the premodern self. Dunaway suggests that they employed the tools of modernity to prevent its disappearance: "as they photographed places of silent beauty and expressions of physical force, they also hunted for images of themselves. 28

\section{Shooting One's Self}

Sometimes this hunt was quite literal, as Warburton Pike, in the 1917 reprint of The Barren Ground of Northern Canada, made clear with the image of himself "ready for tracking." [Plate 17] In sharp contrast to the normally refined author's profile that would open a book, Pike's image deliberately styles him as hyper-masculine. The 'Canadian look' sported by Pike in 'ready for tracking' was developed in Britain by the earlier Scottish adventurer and author of The Young Fur Traders, Robert Ballantyne. Richard Phillips describes Ballantyne as coming "to embody a theatrical Canadian manliness, which appealed to the crowds who paid not only to read his books, but also to see him on stage, singing voyageur songs and telling tales of life in the wilds." 29 Gillian Poulter suggests that snowshoeing and hunting had an important place in 'indigenizing' Euro-Canadians after 1867, by appropriating Aboriginal ways of living in the landscape

\footnotetext{
27 "The Musk-Ox at Home" New York Times 8 March 1896: 29.

${ }^{28}$ Finis Dunaway, "Hunting with the Camera: Nature Photography, Manliness, and Modern Memory, 1890

- 1930," Journal of American Studies 34.2 (2000): 210.

${ }^{29}$ Phillips, Mapping Men and Empire, 47-8.
} 


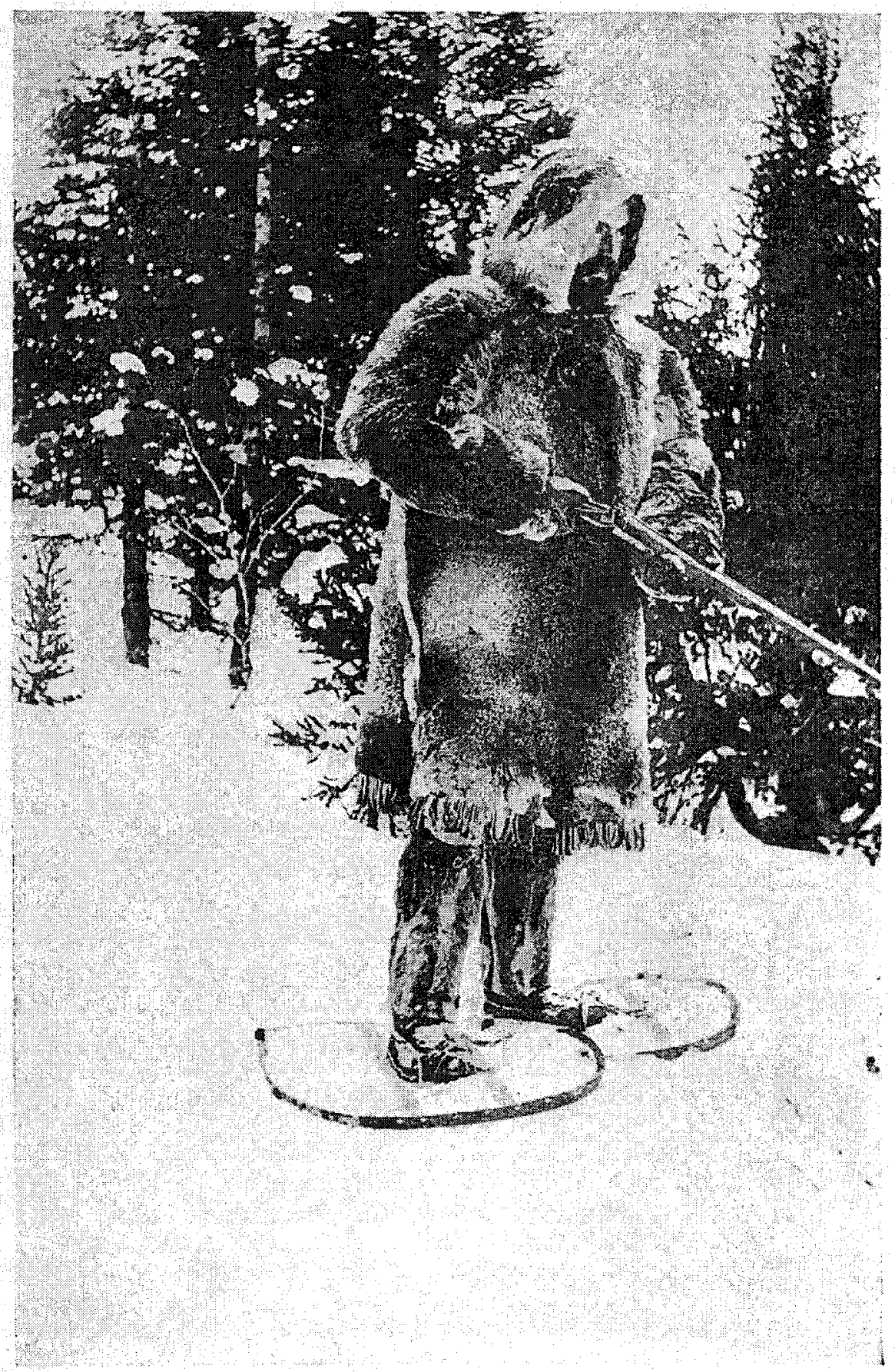

Ready for Tracking

\section{Plate 17: Ready for Tracking}

Source: Warburton Pike, The Barren Ground of Northern Canada (New York: E.P. Dutton \& Company, 1917), ii. 
"was one way colonists could feel themselves to be indigenous and claim a new national identity. ${ }^{30}$ Like Ballantyne, Pike's stylized and 'indigenous' image points to the wider aspect of performance that must be evaluated in order to assess the photographic relationship that organized the metropolitan fantasy of the hunt in the Far North.

The power that explorers invested in photographs was derived from a nineteenthcentury understanding that outwardly visible attributes were characteristic of one's inner morality. The power of images to represent the primitive depravity of 'uncivilized' subjects reflected white metropolitan beliefs about what constituted civilized morality. Consider Warburton Pike's first 'encounter' with the feared Inuit:

The next morning we picked out of our trading-stock a few presents to be left in the Esquimaux camp, as a sign that there were people in the interior willing to be on friendly terms with the people of the coast. Knives, axes, beads, and files, a couple of hand-mirrors, a few strips of red cloth, and a flannel shirt or two were stuffed into a copper kettle, which would be itself the biggest prize of all. On lifting the lid, the first object to meet the eye of the wondering Esquimaux would be the photograph of the Protestant missionary at Fort Resolution, which David had been keeping among his small stock of treasures; it was a photograph of a Church of England clergyman, in clerical costume, and should certainly give the Esquimaux a favourable idea of the style of man who had visited their camping-place. ${ }^{31}$

The close encounter is moderated by Pike's sense of what a photograph can convey. Its juxtaposition with the tools and clothing of civilization must be understood within the visual framework that connected the kettle as a domestic tool, the religiosity conveyed by the priest's robes, and the red cloth, all as they would have meant to what Pike imagined to be a normalized 'eye' of wonder passing over the objects. Pike's eye was trained to see the orderly and moral message in such objects, much in the same way the explorer's

\footnotetext{
${ }^{30}$ Gillian Poulter, "Montreal and Its Environs: Imagining a National Landscape, C. 1867-1885," Journal of Canadian Studies 38.3 (2004): 72.

${ }^{31}$ Pike, Barren Ground, 209-10.
} 
'eye' hunted and projected metropolitan systems of value onto the Native peoples they encountered.

The ability of photographs to capture and reveal moralizing codes meant that two photographs could chart moral progression. As Suren Lalvani has convincingly shown, photography did not aid the penetrative gaze's ability to register outward moral characteristics, but the camera, in amassing an archive of reproducible images, produced a 'normative' standard of appearance by which it became possible to "constitute the subject within a discursive field." Photography's power was, "its ability to reify multiple bodies into particular types of bodies." ${ }^{32}$ In 1895, Reverend P.L. Spencer vowed that noone could dispute the role of photography as a 'handmaiden of religion' when a viewer, ...is shown in succession on the lantern screen, two representations of 'a heathen man', on depicting him as a savage, the other as a Christian gentleman. The missionary's spiritual medicine is acknowledged to work a greater charm than any of the advertised panaceas whose supposed wonderful effect are indicated by the contrast between 'before taken' and 'after taken.'33

Left without the benefits of religion, Reverend Spencer warned, one could become the woman from St. Paul's he called "the mummy ... she was a sample of what paganism does in the way of caring for the aged and infirm. Left by her heathen relatives to wander about in quest of bones and remnants of meat at the village butcher shop."34 The muchlauded missionary, who oversaw the Athabasca-Mackenzie system, Bishop Bompas,

\footnotetext{
${ }^{32}$ Suren Lalvani, Photography and the Production of Modern Bodies (New York: SUNY Press, 1996), 43.

${ }^{33}$ P.L. Spencer, "The Camera in the Mission Field," The Canadian Photographic Journal 3.5 (1894): 206.

${ }^{34}$ P.L. Spencer, "The Camera in the Mission Field: Algoma and the West," The Canadian Photographic Journal 4.5 (1895): 123.
} 
known as the 'Apostle of the North,' supplied similar evangelical warnings through photography, as seen in "An Old Indian Deserted by His People." 35 [Plate 18]

The transformative power of photographs also worked in 'reverse,' as the photographic record surrounding the missionary Egerton Ryerson Young displayed. His 1890 novel, By Canoe and Dog-Train: Among the Cree and Salteaux Indians, a sportsman's adventure story written as missionary memoirs, begins with an outline sketch and photographs of several successfully converted Natives in a section called 'work done,' before setting about recounting Young's expeditions into the foreboding 'great lone land. ${ }^{36}$ The stern and resolved image of Young greeting the reader is transformed, before travel into the 'Far North,' into the image of Canadian manliness by donning new apparel. [Plates $19 \& 20]$

Young's emplotment in a series of studio-set images testifies to the transformative power of the camera with the transformative power of the gun. Kristin Burnett adds that Young's missionary outlook included a gendered vision of Christianity that was involved material transformation as well. Burnett has shown that Young imagined Native men to be abusive, and believed that "once Aboriginal women converted to Christianity and adopted the precepts of Euro-Canadian culture ... it would change the way Aboriginal women were treated by their male counterparts. ${ }^{37}$ Young's photographs are illustrative of this assumption. Having changed into a new man by donning his leather clothing, Young was transformed into a man able to saddle his gender-defined responsibility and

\footnotetext{
${ }^{35}$ H. A. Cody, An Apostle of the North: Memoirs of the Right Reverend William Carpenter Bompas, D.D (New York: E.P. Dutton, 1908), 95

${ }^{36}$ Egerton R. Young and Mark Guy Pearse, By Canoe and Dog-Train among the Cree and Salteaux Indians (New York, Hunt, 1890), 1-40.

${ }^{37}$ Kristin Burnett, "Aboriginal and White Women in the Publications of John Maclean, Egerton Ryerson Young, and John McDougall," in Unsettled Pasts: Reconceiving the West through Women's History, ed. Sarah Carter, et al. (Calgary: University of Calgary Press, 2005), 114.
} 


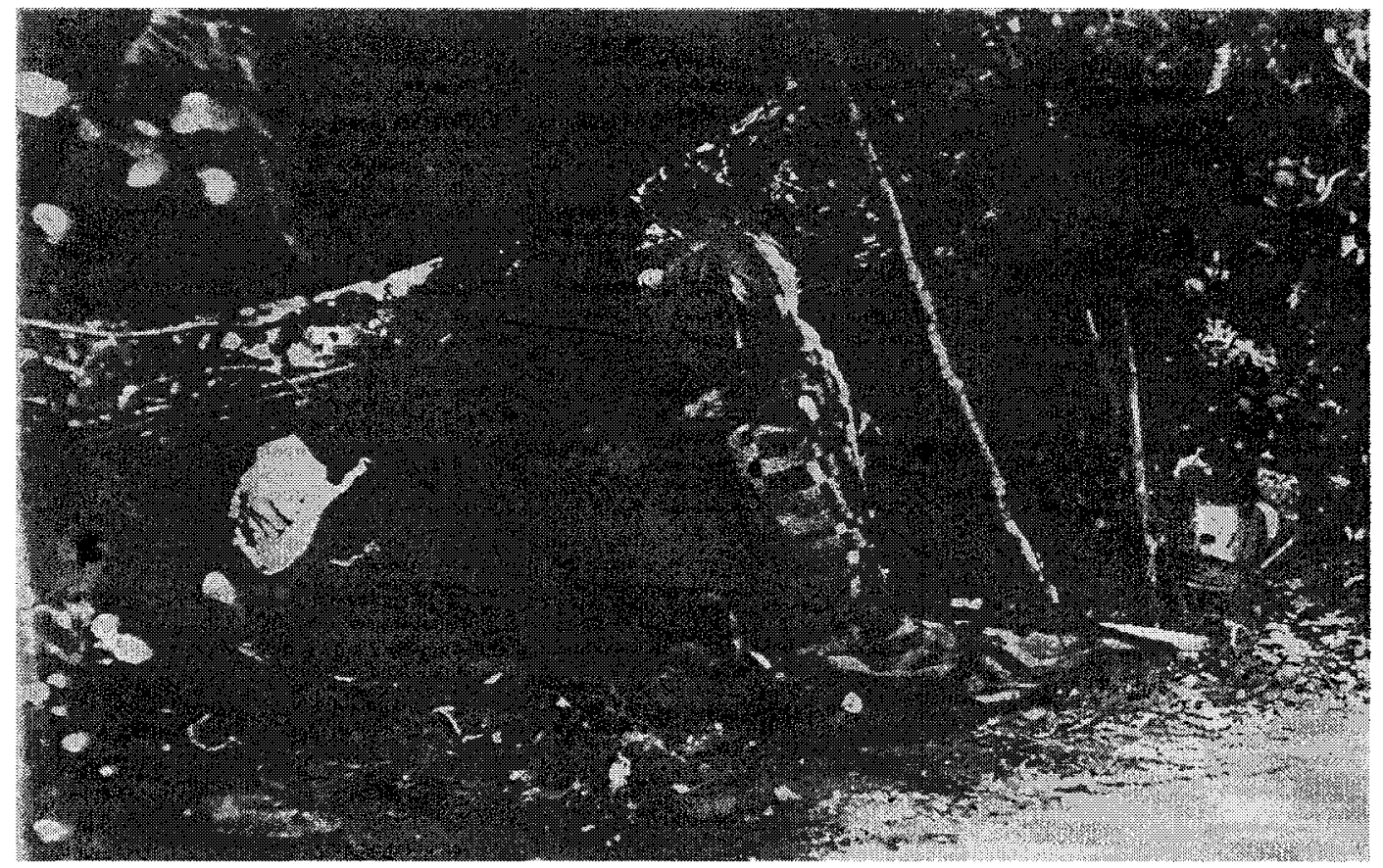

\section{Plate 18: An Old Indian Deserted by His People}

Source: H. A. Cody, An Apostle of the North: Memoirs of the Right Reverend William Carpenter Bompas, D.D (New York: E.P. Dutton, 1908), 95. 


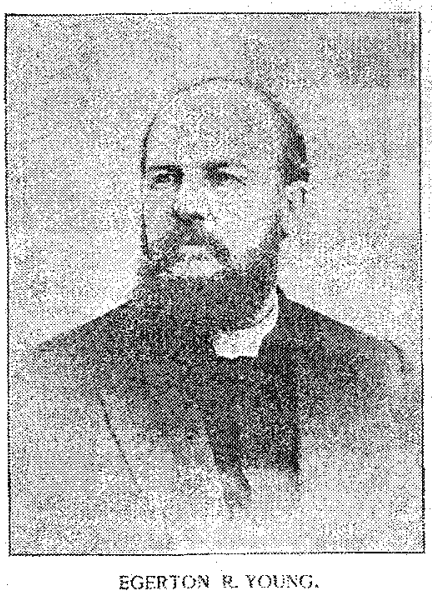

\section{Plate 19: Egerton R. Young}

Source: Egerton R. Young and Mark Guy Pearse, By Canoe and Dog-Train among the Cree and Salteaux Indians (New York: Hunt, 1890), i.

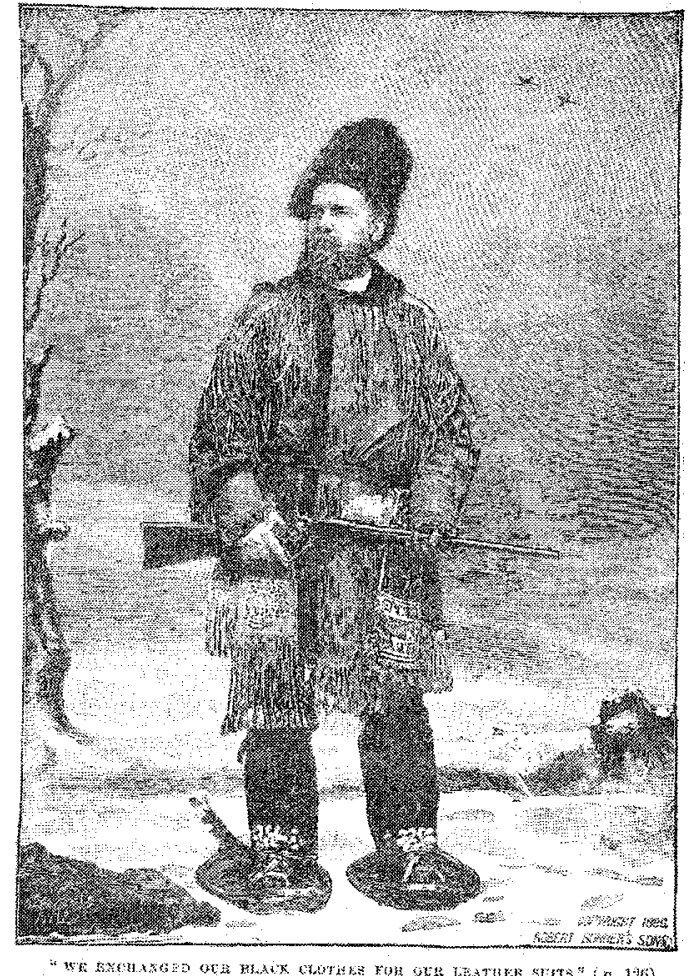

Plate 20: "We exchanged our black clothes for our leather suits"

Source: Egerton R. Young and Mark Guy Pearse, By Canoe and Dog-Train among the Cree and Salteaux Indians (New York: Hunt, 1890), 127. 
employ his prowess as a hunter to save his starving wife and win converts: "I took down my rifle, and tied on my snow-shoes, and started off looking for game. ... Pictures II. And III. Tell [sic] the rest of the story." [Plate 21] A proud Reverend rests his foot upon the painted carcass of a female deer and welcomes prospective converts, "Come share with me our savory venison." 38 [Plate 22] Burnett explains that missionary stories "were used to not only to attract public attention ... but to serve the broader colonial project, which sought to design and build a White settler society by physically and socially marginalizing First Nations people."39

Burnett, however, misses the ironic desire to access the primitive masculinity of the hunt, namely the primitive masculinity Young imagined and desired in 'authentic' Native men, which could explain his short photographic narrative. Photography's ability to help imagine moral and material transformations was matched only by a scientific vision that used the camera for the same ends. In his published anthropological study, Frank Russell supplied prolonged and gratuitous episodes from hunting expeditions in the name of taxonomy, and included various poses of the author himself costumed in the clothing of the Dog Rib people. [Plate 23] Shari Huhndorf observes that "playing Indian - temporarily donning Native costume and emulating Native practices ... has historically aided European Americans in various quests for identity and authenticity. ${ }^{, 40}$ Huhndorf has shown that while men like Russell imagined their primitive, masculine self by wearing the clothes of the Inuit, by locating Inuit artefacts and under scientific headings like 'ethnographic' or 'natural history,' they imagined the real Inuit people as ultimately

\footnotetext{
${ }^{38}$ Young and Pearse, By Canoe and Dog-Train, 195.

${ }^{39}$ Burnett, "Aboriginal and White Women," 103.

${ }^{40}$ Shari M. Huhndorf, Going Native: Indians in the American Cultural Imagination (Ithaca and London: Cornell University Press, 2001), 6.
} 

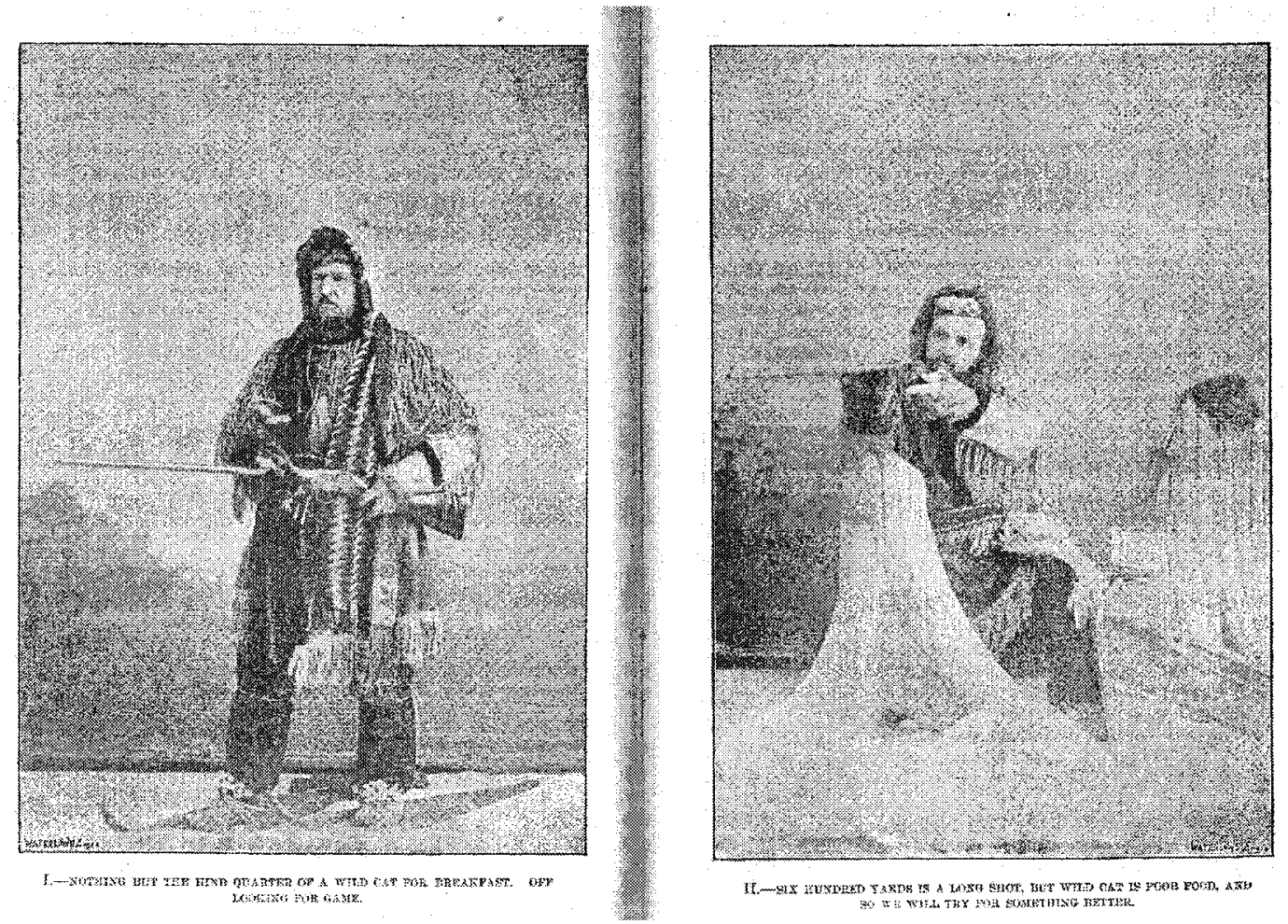

Plate 21: I. - Nothing but the hind quarter of a wild cat for breakfast, off looking for game. [and] II. - Six hundred yards is a long shot, but wild cat is poor food, and so we will try for something better.

Source: Egerton R. Young and Mark Guy Pearse, By Canoe and Dog-Train among the Cree and Salteaux Indians (New York: Hunt, 1890), 193-194. 


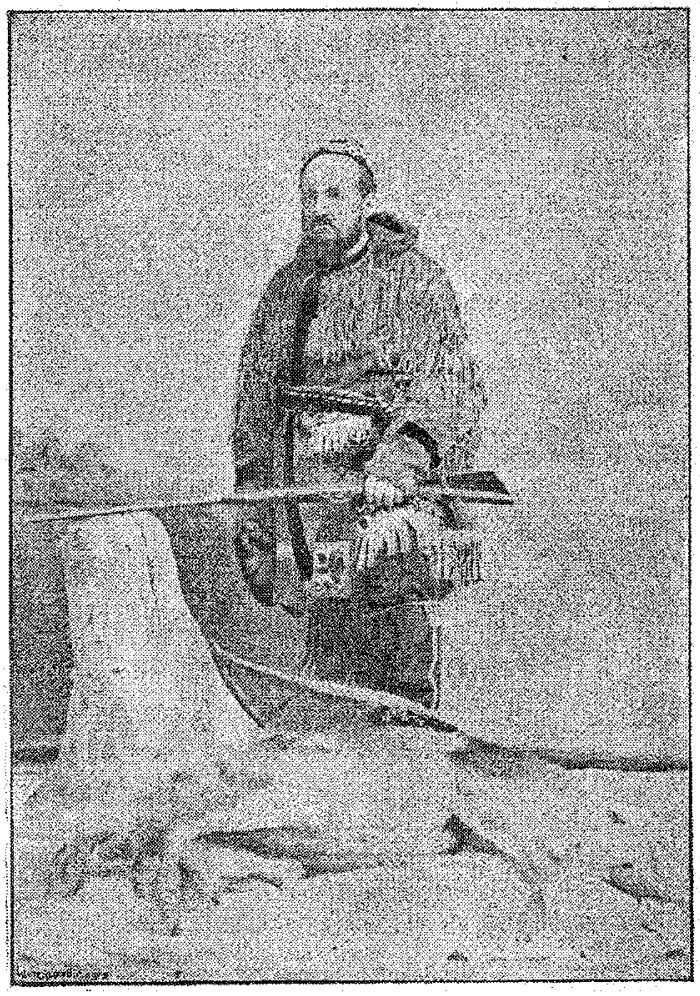

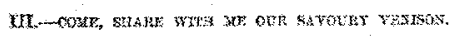

\section{Plate 22: III. - Come, share with me our savory venison}

Source: Egerton R. Young and Mark Guy Pearse, By Canoe and Dog-Train among the Cree and Salteaux Indians (New York: Hunt, 1890) 195. 


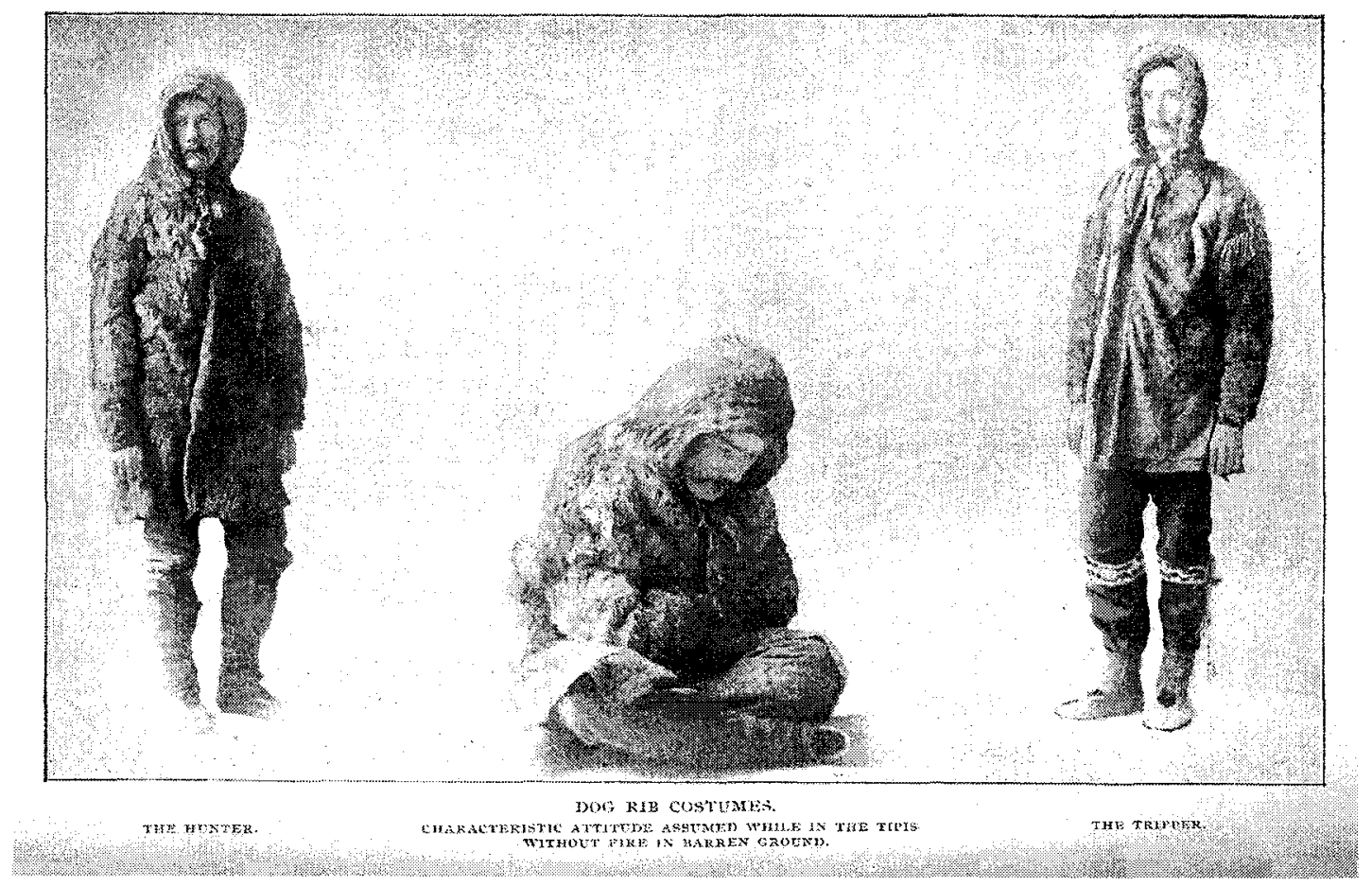

\section{Plate 23: Dog Rib Costumes}

Source: Frank Russell, Explorations in the Far North: Being the Report of an Expedition under the Auspices of the University of Iowa during the Years 1892, '93, and '94 (Iowa City: University of Iowa, 1898), facing 115. 
passive subjects. "These scientists," she continues, "placed them - along with animal specimens and other 'primitive peoples' - in the realm of 'natural' (i.e., prehuman, or at least precivilized) history. They thus rendered them irrevocably primitive, savage, other." 41

Russell had departed for the Barren Lands a representative of the University of Iowa and was seeking natural history specimens for the official museum of the same state. ${ }^{42}$ According to one anthropology professor, the expedition was devised by Roderick MacFarlane, the noted ornithologist and $\mathrm{HBC}$ chief factor at Fort Chipewyan. MacFarlane had encouraged the Anthropology Department of the university, where Russell was a student, to "undertake the work of securing a series of the musk-ox, which he believed to be on the verge of extinction owing to the increasing activities of the Indians on the southern, and the Esquimo on the northern, borders of its range."43

Russell was a characteristic practitioner of what James Clifford has termed 'ethnographic subjectivity. ${ }^{44}$ Clifford describes the late nineteenth-century surge in field-work and participant observation in anthropology as symptomatic of a specifically modern cultural individual. This individual was located in a unique historical moment, where "an ethnographic conception of culture became possible, suggesting a world of separate, distinctive and equally meaningful ways of life ... a state of being in culture while looking at culture." Collecting cultures was intensified a way of defining one's self. Caspar Whitney, for example, was regaled by one journalist for returning with, "a

\footnotetext{
${ }^{41}$ Huhndorf, Going Native: Indians in the American Cultural Imagination, 88.

${ }^{42}$ Russell, Explorations, iii.

${ }^{43}$ Roderick MacFarlane Fonds (LAC) MG29 A11 \#1958, 'Obituary of Frank Russell' reprinted from The Iowa Alumnus of 15 December 1903.

${ }^{44}$ James Clifford, The Predicament of Culture: Twentieth-Century Ethnography, Literature, and Art (Cambridge: Harvard University Press, 1988), 92.

${ }^{45}$ Clifford, The Predicament of Culture, 92.
} 
fund of information [about the Barren Lands] which he will give to the public in a series of articles." ${ }^{96}$ More important, however, was the new masculine self Whitney had acquired in that "inhospitable and inaccessible region," and which the author could now demonstrate. As the New York Times described, "he secured a collection of trophies of the chase and specimens of Indian fancy work, which almost fill the cozy bachelor apartment he occupies." 47

\section{Collecting with the Camera}

While Frank Russell collected aspects of the North and 'other' Native and Inuit cultures, he also discursively inscribed his position as observer and anthropologist. Russell's exuberance in retelling an episode from a hunting trip in Saskatchewan en route to the North positively identifies the 'collecting' with the jocularism of the popular male pastime of hunting: "This was my first moose, and I had secured two excellent specimens, and felt justified in giving vent to my feelings in a shout of triumph."48 While Clifford defines collecting as "a set of social relations" that produce "cultural others and interpreting selves," the theory may be extended to encompass photographic encounters in the North. ${ }^{49}$ Russell's photographic categorization and production of the things that constituted the North empowered him as a knowing subject. The same assumptions about cranial anthropometry that led Russell to collect Broca samples and acquire, "two Dog Rib skeletons at Rae; and at various points between the mouth of the Mackenzie River and Herschel Island, I collected nine crania of Western

\footnotetext{
46 "In The Barren Ground" New York Times 22 June 1895: 8.

47 "In The Barren Ground" New York Times 22 June 1895: 8.

${ }^{48}$ Russell, Explorations, 6.

${ }^{49}$ Clifford, The Predicament of Culture, 112.
} 
Eskimos, ${ }^{, 50}$ are implicit in the carefully numbered and presented 'ethnological material' section of Explorations in the Far North. In the measured space of the museum, Russell would use his camera to effect the same measured organization to order information about 'Eskimo Pipes' and other ethnographic evidence he acquired. [Plates $24 \& 25$ ] Photography, hunting, mapping, collecting and publication, all combined to establish a particularly metropolitan network of constitutive facts and knowledge about the North. "The only way to collect is to collect," became Russell's modus operandi for his daily hunting or natural history excursions, which also formed the basis of his photographic record of the North. ${ }^{51}$ After spending 1892 to 1894 in the North, Russell published his story in 1898 , the same year he completed his Harvard doctorate under the supervision of renowned anthropologist and Chicago World's Fair promoter, F.W. Putnam. ${ }^{52}$ Once an instructor, Russell continued to deliver lantern slide lectures featuring his photographs, illustrated by "Athabascan Myths" and accompanied by the musk-ox samples he acquired, according to one astonished reviewer, "the securing of which nearly

\footnotetext{
${ }^{50}$ Russell, Explorations, 199. An episode Russell describes during his 'preparatory' season at Grand Rapids, Saskatchewan, before heading for the real North, tells of the uneasy connections between collecting, racial hierarchies, 'modernity' and violent appropriation: "at the foot of the rapids, lay a heap of brush, which, I was told, marked the resting place of an old chief who, when dying, had directed that his people should lay him to rest beside the singing waters, and that everyone in passing should break a twig and throw it upon his grave. So faithfully had his wish been complied with that a heap of brush three feet in height had been accumulated. The tradition added to the probability that the grave contained the remains of a Cree of pure blood. Any investigation on my part, had it become known, would have made further residence at Grand Rapids very unpleasant. I proceeded, therefore, to examine the place alone. Clearing away the rubbish and a poplar tree, six inches in diameter, which grew directly over the grave, a number of flat stones were exposed. After digging through three feet of sandy loam, a mass of decayed birch-bark was disclosed under which lay the skeleton, reclining upon the left side with the legs drawn up. The head was towards the east. A small neatly carved pipe of dark fine-grained schist lay beside the skull. A few flakes of rust - all that remained of a knife - and a couple of ounces of shot, indicated that his death had occurred since the advent of the whites." Russell, Explorations, 3.

${ }^{51}$ Russell, Explorations, 223.

${ }^{52}$ Roderick MacFarlane Fonds (LAC) MG29 A11 file.1958, 'Obituary of Frank Russell' reprinted from The Iowa Alumnus of 15 December 1903.
} 
200

EXPLORATIONS IN THE FAR NORTH

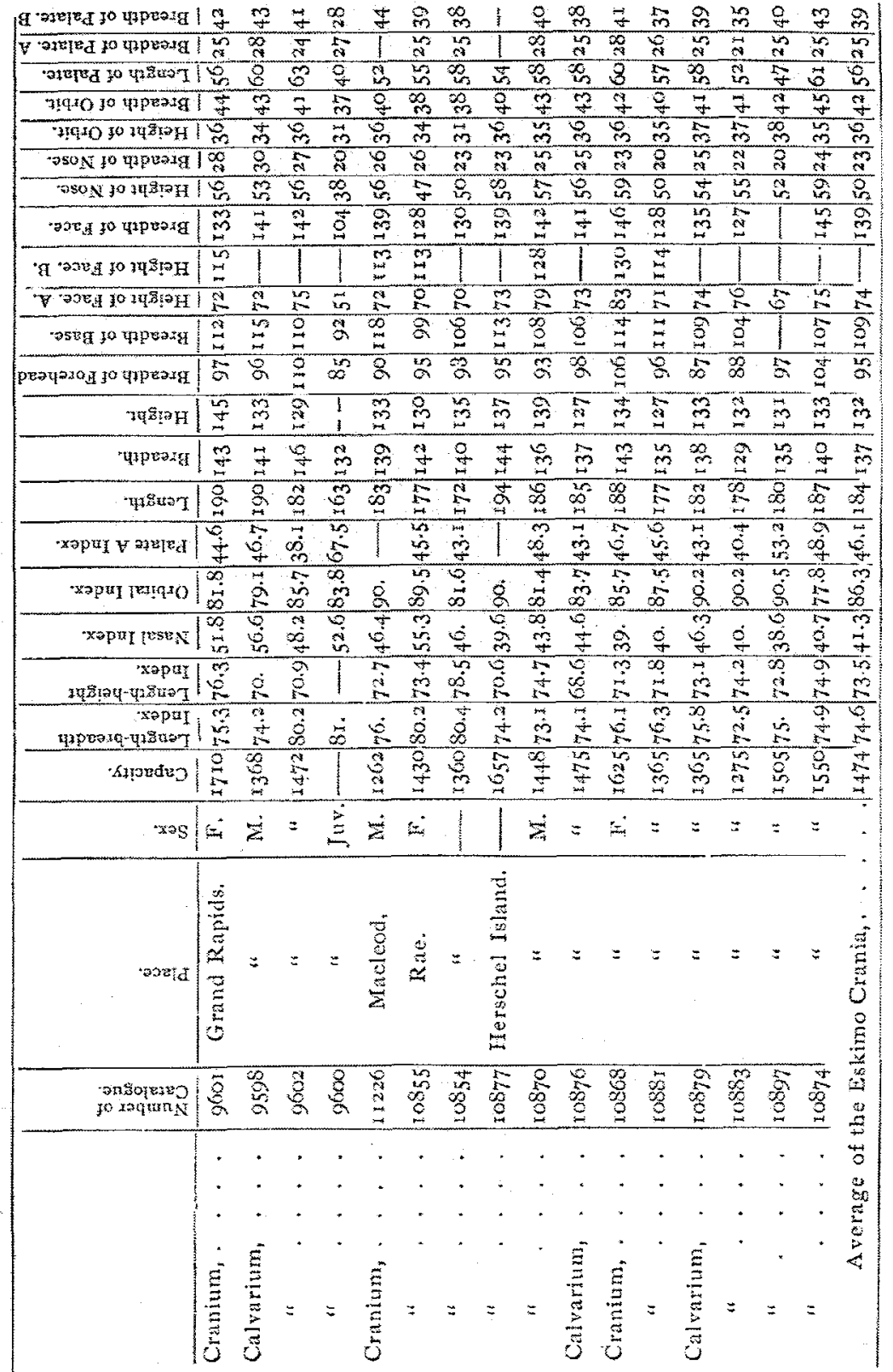

Plate 24: Eskimo Crania obtained with Broca's gauging instruments and No. 8 shot

Source: Frank Russell, Explorations in the Far North: Being the Report of an Expedition under the Auspices of the University of Iowa during the Years 1892, '93, and '94 (Iowa City: University of Iowa, 1898), 200. 


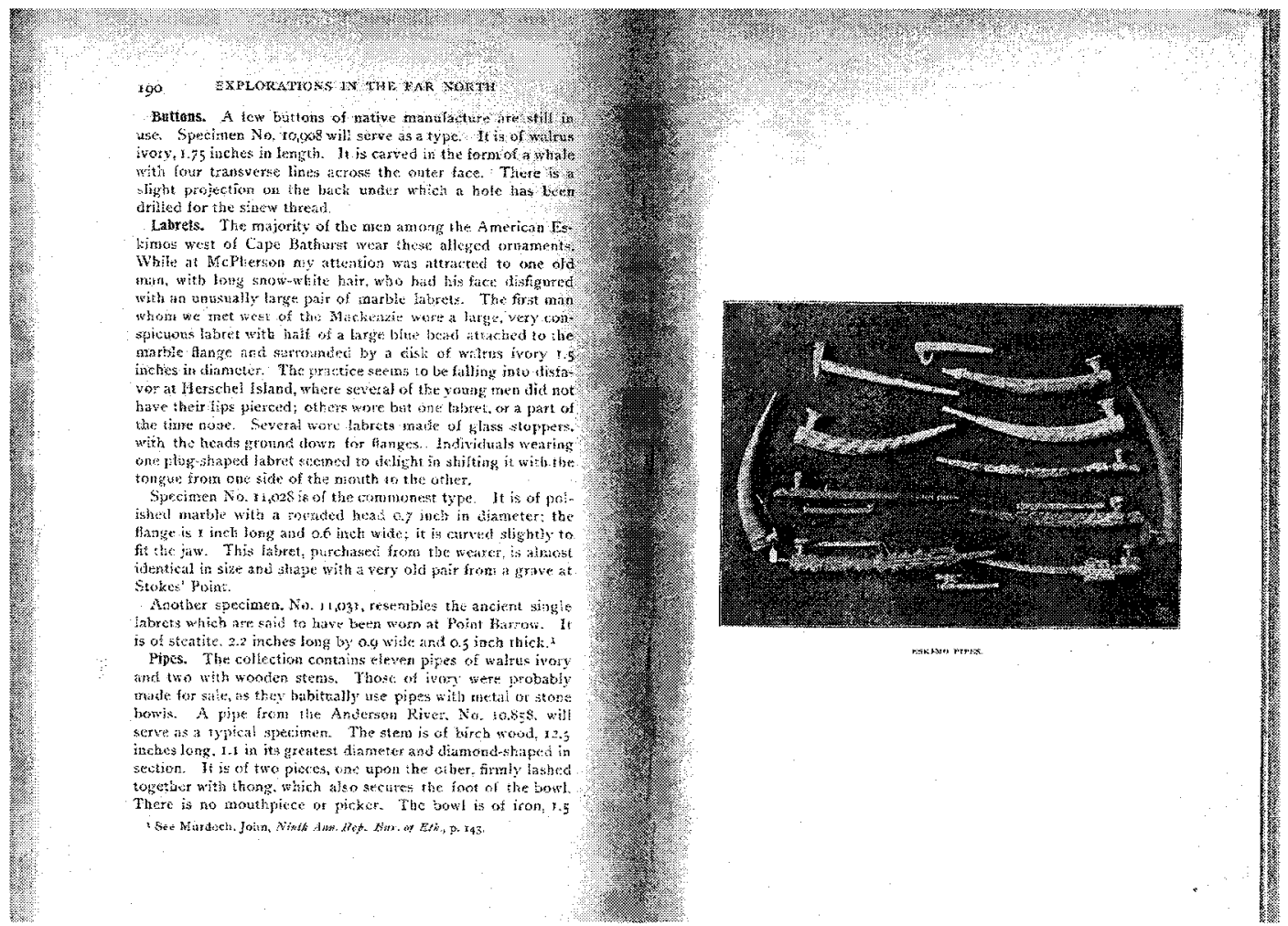

\section{Plate 25: Eskimo Pipes}

Source: Frank Russell, Explorations in the Far North: Being the Report of an Expedition under the Auspices of the University of Iowa during the Years 1892, '93, and '94 (Iowa City: University of Iowa, 1898), 190. 
cost the explorer his life." ${ }^{, 53}$ Photographic circulation in print and public lecture became an important aspect of a larger economy of presenting the North.

Publishing illustrated adventure stories about the Athabasca-Mackenzie basin and the surrounding Barren Lands framed the relationship between the metropole and the frontier along an axis of perception that rendered the latter a passive, if hostile and dangerous, subject of circulating knowledges. Revisiting Foucault's post-structuralist theories in a colonial context, Daniel Clayton has described this process as establishing the "truth status of texts":

...the meanings they create, the sites they work through, the realities and contexts they fashion, the understandings and stories they encourage and disguise, and the power relations they induce and bolster. ... the capacity to build and sustain some truths about land and people, and to denigrate and marginalize others - is a constitutive feature of Western dominance. ${ }^{54}$

Although there has been extensive discussion on the camera's dubious and socially-constructed credentials as a technology for recording and substantiating 'objective truth', it is still worthwhile noting that nineteenth-century expectations about photography's power to reliably re-present the world buttressed the 'truth status' of photographs from the North. ${ }^{55}$ An episode transpiring after Caspar Whitney's last muskox hunt displays a particularly illuminating connection between photography, Northern character,' and truthfulness:

\footnotetext{
${ }^{53}$ Frank Russell, "Athabascan Myths," The Journal of American Folklore 13.48 (1900): 11, "Around the Arctic Circle," Washington Post 3 Feb. 1900: 2.

${ }^{54}$ Daniel Clayton, Islands of Truth: The Imperial Fashioning of Vancouver Island (Vancouver: UBC Press, 2000), xiv.

${ }^{55}$ Roland Barthes, Camera Lucida (New York: Hill and Wang, 1981), Carl Berger, The Sense of Power: Studies in the Ideas of Canadian Imperialism, 1867-1914 (Toronto: University of Toronto Press, 1970), Victor Burgin, Thinking Photography (London: MacMillan, 1982), to list some foundational titles. Historical geographer Brian Osborne has recently observed that, "the camera, always produces sites of contested meanings that challenge the myth of "photographic truth." Osborne, "Constructing the State," 162.
} 
Everybody in Chipewyan was much interested in my trip to the Barren Grounds and its success, and Bishop Grouard and Dr. Mackay wanted to give me an affidavit of my having actually made it, because, as they said, people might not credit it, and they themselves would not have believed it had they not positive knowledge of its accomplishment. I told them, however, I thought my word good with the American public, and if I flattered myself in that belief my camera was a witness that could not be denied. ${ }^{56}$

Again echoing Foucault, Clayton asserts that in spaces of colonial contact, power is too easily explained by suggesting it is solely the extension of a fixed location in economics, governance, or military force. Relations of power, he contends, are also constituted through representation and reproduction: "the peoples and spaces represented in Western texts were simultaneously captured as part of a local scene and positioned elsewhere, in other registers, narratives, and imaginative processes; they became embedded and disembedded within Western systems of thought and experiences." ${ }^{\circ 57}$ An exemplary operation of Clayton's conception of power along an axis between 'local' and 'global' imaginations comes from Charles Tuttle's experience at Churchill on Hudson Bay. Tuttle's government-sponsored 1884 exploration of the North-West passage, known as the Hudson's Bay Expedition which included Robert Bell, was docked at Churchill to attend a Sunday service. Mr. Fox, the Expedition photographer, who, to look at, according to Tuttle, "was to see a camera in one hand and a set of wooden legs in the other, with a package of prepared plates under each arm ... [was] fully determined to photograph both preacher and congregation." ${ }^{, 58}$ The reverend ordaining the service was unimpressed that his Native converts and he should be photographed on the Lord 's Day.

\footnotetext{
${ }^{56}$ Whitney, On Snow-Shoes, 312.

${ }^{57}$ Clayton, Islands of Truth, xiii.

${ }^{58}$ Fox in Charles R. Tuttle, Our North Land: Being a Full Account of the Canadian North-West and Hudson's Bay Route, Together with a Narrative of the Experiences of the Hudson's Bay Expedition of 1884 , Including a Description of the Climate, Resources, and the Characteristics of the Native Inhabitants between the 50th Parallel and the Arctic Circle (Toronto: C. Blackett Robinson, 1885), 127.
} 
Mr. Fox persisted however, asking "would it be too much, ... to get the people together at the door of the church, just for a few seconds; and there, with their shepherd at their front, I could secure a photograph of the whole, the little church included, in less than a minute. The people of Canada would be glad to see such a picture." Tuttle commentated that "the reverend gentleman began to understand the position. He thought that perhaps the emergency would warrant the seeming disregard of the Sabbath; and, after a few hurried words with the chief trader, gave his consent and began to get the motley crowd into position." $" 59$ There are two imagined ideologies: one, on behalf of Tuttle, Bell, and Fox seeking in the North a 'sight' of future progress; and the reverend, who believed the steady transmission offered by the photographic practice would communicate to the rest of Canada the importance of the 'site' of the Northern missions.

That the camera, the gun, and the book could be conceived as both material and imaginative processes was most transparently evoked by Whitney. Having almost reached the Arctic coast after his push into the Barren Lands and exhausted their supplies, Whitney and his party were making the long hike back to the treeline. Upon encountering a herd of musk-ox, and having secured enough 'specimens' to satisfy his goals, Whitney described having "no wish to shoot for the mere killing" for the first time: "I gave my rifle to Beniah," he continued, and "shouldered my camera instead." language connecting camera and gun continues as he "got within camera range" of an injured ox cornered by his Native guides, but missed the shot before they killed it. Undaunted, Whitney followed the hunters with a heightened tenacity only made plausible by the camera: "I increased my efforts to get within camera range before the killing was

\footnotetext{
${ }^{59}$ Tuttle, Our North Land, 134.

${ }^{60}$ Whitney, On Snow-Shoes, 269.
} 
ended. I reached the scene of action while there were yet three cows and a couple of calves standing, and 'pressed the button.' Before I could turn a fresh film into my camera the cows were down; but I secured two more plates of the calves while they were standing at bay before the dogs, and subsequently two plates of the general scene.",61 [Plate 26]

The imaginative process did not end with the killing and photographing of the musk-ox. Unable to secure a perfect image, Whitney had many of his shots retouched or entirely re-drawn by his colleague at Harper's Magazine, Frederick Remington. Remington, like his less-famous Canadian counterpart Arthur Hemming, specialized in recreating romantic scenes of primitive life outside civilization. Both Heming and Remington worked on Whitney's Snow-Shoes to the Barren Grounds to complete poor quality photographs and draw-from-scratch scenes that Whitney had not been able to take on his own. For example, while trying to photograph some Cree at the Lac La Biche HBC post, Whitney explained that "these people had never before seen a camera, and many of my plates show them scurrying away or turning their backs." Luckily, his illustrators were ready to recreate the scenes for him without the same disruption. ${ }^{62}$ [Plate 27]

The narrative mode described by Martha Sandweiss that characterized nineteenthcentury photography led explorers to great lengths to complete the visual imaginings of their stories. Travellers mapped the scopic regime of the camera back onto the very landscape they encountered. Thus, J.W. Tyrrell produced adjectives to describe his drift down the Athabasca: "On the morning of the $1^{\text {st }}$ of June camp was called early, and we

\footnotetext{
${ }^{61}$ Whitney, On Snow-Shoes, 270.

${ }^{62}$ Whitney, On Snow-Shoes, 34.
} 


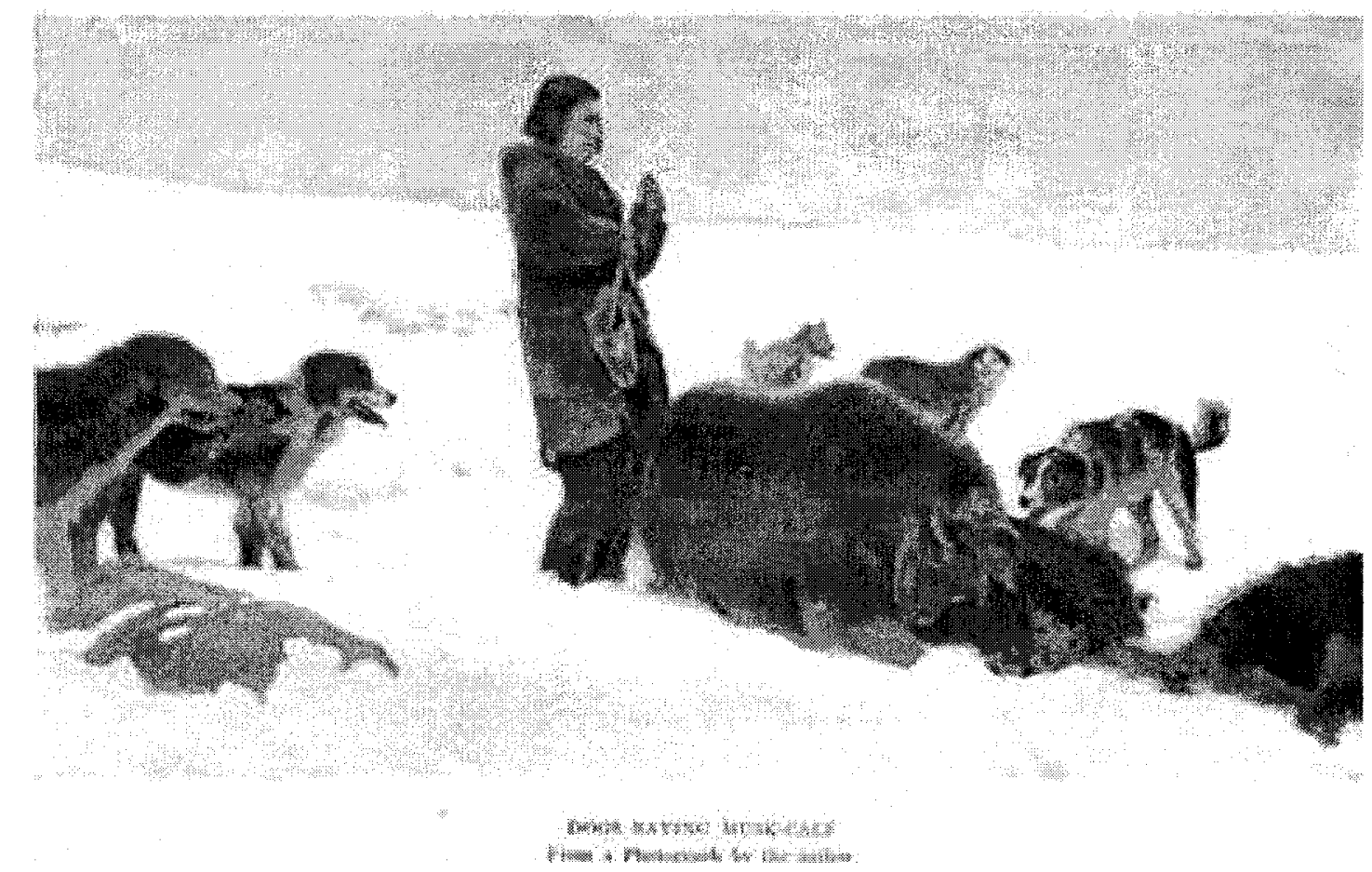

Plate 26: Dogs Baying Musk-Calf

Source: Caspar Whitney, On Snow-Shoes to the Barren Grounds: TwentyEight Hundred Miles after Musk-Oxen and Woodbison (New York: Harper \& Brothers Publishers, 1896), 269. 


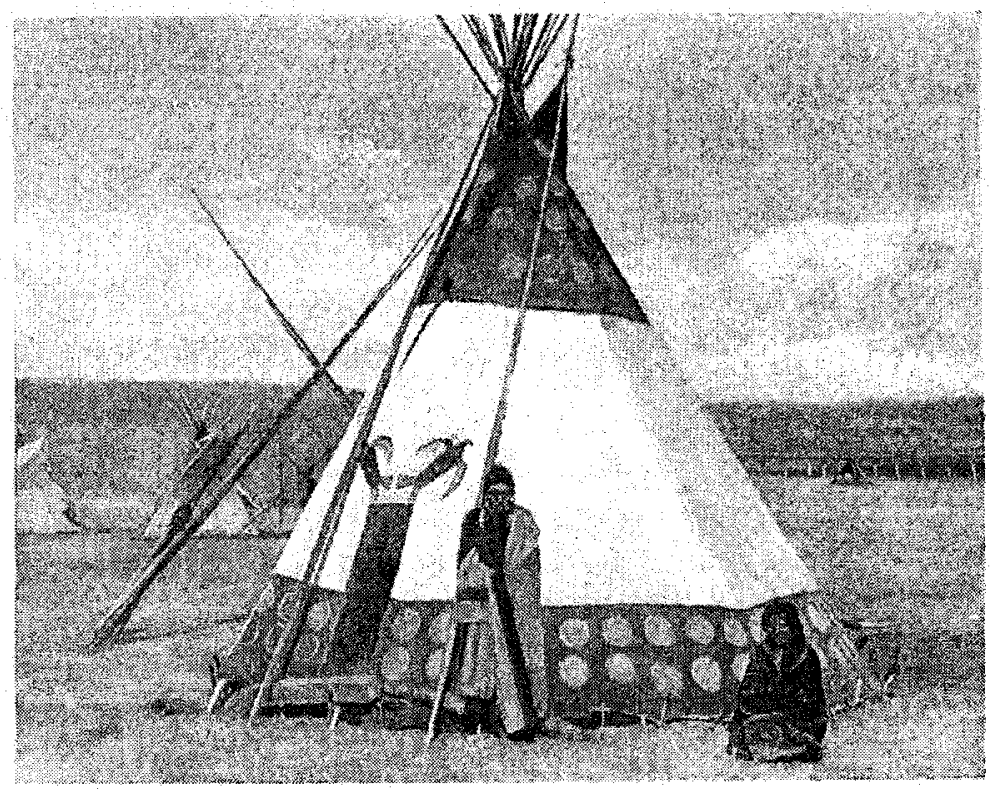

A MEDTCINE-MAN's LODGE

\section{Plate 27: A Medicine-Man's Lodge}

Source: Caspar Whitney, On Snow-Shoes to the Barren Grounds: TwentyEight Hundred Miles after Musk-Oxen and Woodbison (New York: Harper \& Brothers Publishers, 1896), 12. 
continued on our way. As we glided down stream a succession of grand views passed, panorama-like, before us. ${ }^{\text {"63 }}$ Most importantly, however, they mapped powerful images of metropolitan civilization onto what they saw as a disappearing primitive frontier.

\section{Conclusion - Regeneration}

Finis Dunaway further asserts that, like conservationists who photographed extirpated animals, "images of Indians contributed to their project of racial and manly regeneration." ${ }^{64}$ John McDougall, the son of a missionary sent to Fort Edmonton in the $1860 \mathrm{~s}$, described the Stoney Indians (Nakoda) he encountered while duck hunting as two young men, "strong and well-built, with immense muscular development in the lower limbs. ${ }^{65}$ In Saddle, Sled, and Snow-Shoe, he recalled:

Both were fine looking men. Their long black hair, in two neat braids, hung pendant down their breasts. The middle tuft was tied up off the forehead by small strings of ermine skin. Their necks were encircled with a string of beads, with a sea-shell immediately under the chin. A small thin, neatly made and neatly fitted leather shirt, reaching a little below the waist; a breech cloth, fringed leather leggings, and moccasins, would make up the costume; ... They looked true specimens of the aboriginal man ... I could not help but think of the fearful strain, the terrible wrenching out of the very roots of being of the old life, there must take place before these men become what the world calls civilized. $^{66}$

The veracity of description and the subtle homoeroticism in McDougall's description highlights how the authenticity of the explicitly masculine Native body was intimately connected to their imminent disappearance from the world. The non-threatening Natives are masculanized at the same time they are othered, forcing their uniqueness to stand in contrast not only to white practices of civility, but also to time - these 'true specimens' of

\footnotetext{
${ }^{63}$ Tyrrell, Across the Sub-Arctics, 21.

${ }^{64}$ Dunaway, "Hunting with the Camera," 218.

${ }^{65}$ John McDougall, Saddle, Sled and Snowshoe: Pioneering on the Saskatchewan in the Sixties (Toronto: W. Briggs, 1896), 75 .

${ }^{66}$ McDougall, Saddle, Sled and Snowshoe, 75-6.
} 
manly ways are now gone. McDougall noted, "if these had been the days of the 'kodak,' I would have delighted in catching the picture of those young Indians as they stood before us, exactly fitting into the scene which in its immensity and isolation lay all around us." $" 67$

The significance of ending with this piece by McDougall is that he is from Edmonton and is experiencing the 'old timer' vision of western history characteristic of the broader streams of antimodernism that works through the sport and adventure photographers. To resolve the question of 'why' those novels were written and photographs taken means understanding that adventurers, even when acting in the name of science, went north with deliberately self-involved goals. The photographs do not serve the purpose of any particular state, but rather frame a relationship between civilization and the past, white and Native, nature, hunting, and the camera - frontier and metropole. The relationship between frontier and metropole was thus photographically narrated as much as it was textually developed during the 1890 s. In turn we must consider the relationships of economic colonialism, and ask what narrated, developed, and constituted them, through an examination of cultural representations.

\footnotetext{
${ }^{67}$ McDougall, Saddle, Sled and Snowshoe, 75.
} 


\section{Chapter 4: C.W. Mathers' Visions, 1901}

\section{Introduction - The Lost Masterpiece}

In 1895 an anonymous contributor referring to himself only as 'F.C.S.C.'

contributed an article to The Canadian Photographic Journal describing his travels on

Rainy River the previous summer. The trip was significant because it related the lost

opportunity to create a photograph that the author claimed, "would have been my

masterpiece." FCSC recounted how his steamer heading up river was incapable of

overcoming the current in a particularly strong set of rapids. Unable to continue without

the use of a tracking line from shore to pull the boat up, all the 'available male

population' of the Native village beside the chute was called upon to assist the steamer

upstream. This usual method of ascent was proving ineffective however, so the list of

Euro-Canadian passengers on the boat disembarked to help with the work. FCSC

explained,

I went ashore with the others, taking with me a small hand camera, thinking that possibly I might be able to secure something. The combined efforts of both passengers and natives were insufficient to pull the boat up; twice she reached the crest of the rapid and twice she went back. Before making a third attempt, the captain induced a number of squaws, who had been interested spectators of our previous efforts, to help ... she is unquestionably, among these Indians, the labourer of the household. With the aid of the increased strength, the boat once more reached the crest and, as before, stopped, but this time she did not go back; the long line of struggling beings, red and white, male and female, threw still more weight into their work, the cable tightened, the boat moved a little, then slowly, very slowly, crept up. ... after the crest of the rapid had been passed and a fair start made beyond, I thought that the little pulling I was doing could conveniently be dispensed with, so I left the line and prepared to photograph the situation. ${ }^{\text {' }}$

\footnotetext{
${ }^{1}$ F.C.S.C, "Photography and the Indian," The Canadian Photographic Journal 4.8 (1895): 219 . The best available reading of the (perhaps) acronym 'FCSC' is the U.S. Foreign Claims Settlement Commission, empowered to resolve border disputes. The story takes place on the section of the Rainy River that formed the Canada-US border. FCSC also noted that the Native village beside the river was "on the Canadian side," suggesting a perspective that arose from 'looking across' to Canada.
} 
It is unlikely that any cameraperson encountering the same scene during the $1890 \mathrm{~s}$ would have acted any differently. Professional images of the Northwest's people and places were in great demand for a variety of reasons, not least for their rarity. As FCSC himself explained of his lost shot, "It would have had no equal anywhere on earth. What other circumstances would have furnished the occasion for such a picture?" The answer requires understanding what cultural meanings the photographer believed were located in the diverse group of people hauling on the line. As we have already seen in Chapter 3, to some the photograph would have translated the last vestiges of physical hardship in the back-country, which were fast disappearing as steamers and other aspects of 'civilized life' shrank the imagined spaces of rugged masculinity left in the world. The range of ideologies, desires, and assumptions that every frame was hoped to contain in the photographic encounter could be as diverse as the interpretation of the result. Without a photograph to 'speak for itself', however, FCSC provided his own rationale behind the untaken picture's importance.

Before me were about one hundred people strung along a rope, fifteen or twenty of them white and the rest copper-coloured, the Indian equivalent for the fair sex predominating. There was no defined arrangement as to color or sex, each person had taken hold wherever a vacancy had appeared and the result was that here and there could be seen a white man, and Indian and a squaw, all pulling together. ${ }^{2}$

It was the not the joining of the bodies of the subjects before the unsuccessful camera that called out to FCSC, but their division. The fascinating juxtaposition of white and Indian, man and woman, working towards a common goal would make a photograph par excellance. But the scene did not represent the egalitarian spirit of a new nation that characterized the assimilationist's

\footnotetext{
${ }^{2}$ F.C.S.C, "Photography and the Indian," 220.
} 
attitude towards the Native peoples of Canada. ${ }^{3}$ Instead, the strange juxtaposition of the participants pronounced rather than flattened difference, giving what Malek Alloula calls "figural representation to the forbidden." Locating and fixing each participant in the cross-hairs of gendered and racialized essentialisms, FCSC drew an imaginary hierarchy out of the group fighting the current, "the white man with a must-not-let-her-go-back-again-or-we'll-never-get-her-up expression, the Indian pretending to be doing it all himself, and the squaw hauling like a horse and grinning like an ape."5

\section{Making 'Sense' of Images}

FCSC's experience on the Rainy River informs, in a number of important ways, a similar voyage down the Athabasca-Mackenzie system taken in 1901 by the Edmonton photographer Charles Wesley Mathers. In the same way that FCSC drew the unequivocal line between the different bodies the camera was pointed at and its ability to render a visible hierarchy of race and gender, Mathers was also conscious of the power invested in photography as an ordering technique of vision. Like FCSC, he was aware of the popular desire for unique pictures of life and Natives in the Northwest just as it seemed to be vanishing under the impress of modernity. Addressing those cultural beliefs, Mathers created a set of saleable images intended to render and explain the people and places of the North to a white European population - to open the North to a metropolitan gaze. He did not let the camera 'speak for itself', however, but brought the intentions of a

\footnotetext{
${ }^{3}$ Coates and Morrison, The Forgotten North: A History of Canada's Provincial Norths, 70.

${ }^{4}$ Malek Alloula, The Colonial Harem (Minneapolis: University of Minnesota Press, 1986), 48.

${ }^{5}$ F.C.S.C, "Photography and the Indian," 218.
} 
number of powerful interests along with him, including those of Edmonton freetrader, newspaper editor, and politician Frank Oliver.

Mathers' image-making voyage was highly successful, unlike FCSC. But the material absence of the latter's photograph says as much about the didactic power with which photography was endowed by contemporary viewers. The image-making opportunity was ultimately foiled for FCSC when, "the moment I pointed the camera at them, every mother's daughter of the squaws dropped the line and fled." While the bigotry evident in his magazine submission seems almost a self-verifying prediction, it is important to note the 'sense' FCSC made of the misapprehended photographic encounter. To do so is greatly suggestive of the didactic mechanisms behind the images in Mathers' own voyage and gives insight into the explanatory resolution such meaning-laden photographs were intended to achieve. FCSC noted on one hand his certainty what the 'backwards' and confused women must have thought: "What does he point that thing at me for? That thing that walks on three legs." Alternatively he provided a case where two Native men were photographed shortly before committing a crime and the photographs later aided in their capture. Satisfied that the men were later hanged, FCSC sarcastically posited that, "If the camera is going to combine with the hated pale-face to curtail the innocent pleasures of the down-trodden red man, it is no wonder that those Indians object to it." ${ }^{.6}$ The same teaching power of the photograph FCSC used to magnify his begrudgingly chauvinistic respect for Native men above women, Mathers would employ in rendering the difference between the variety of peoples and places he encountered as he travelled north of

\footnotetext{
${ }^{6}$ F.C.S.C, "Photography and the Indian," 219.
} 
Edmonton. Inasmuch as the narrative arc of Mathers' photographic voyage recorded the growing momentum of 'modernity' in the North, it also re-presented and refracted a perceived difference between the white-European city of Edmonton, the Natives, Euro-Canadians and métis inhabiting the District of Athabasca, and one of the great fascinations of the early twentieth century - the 'perfectly uncivilized' Inuit. In a number of important ways, Mathers' characterization of the Aboriginal peoples north of Edmonton intersected, reinforced, and challenged the cultural matters of structure and perception that characterized the modern, 'opening' of the North.

\section{Mathers Goes North}

Born in Lucknow, Ontario, Charles W. Mathers had been hired as an assistant in Edmonton at a branch studio of Calgary photographers Boorne and May. In 1893, he purchased the same Edmonton studio on Jasper Ave. from his employers and in 1894 completed the deal by acquiring all of Boorne and May's stock negatives when their Calgary studio folded. ${ }^{7}$ By 1901 , the successful cameraman travelled to the Arctic Circle with a free trader in order to photograph the water routes leading to the Arctic Ocean. When he returned, the Department of Agriculture published Mathers' photographs in a souvenir book called The Far North. In subsequent years, the photographs were published in A Souvenir from the North, and through the Albertype Company of New York again as The Far North. Although Mathers made close to 400 images during the three months he travelled in northern Alberta, the souvenir books often contain no more than twenty prints, and are limited to a small range of subjects. The images chronicle his voyage down the Athabasca River, onto Athabasca Lake and, by way of the Slave River

\footnotetext{
${ }^{7}$ Brock V. Silversides, "Charles Wesley Mathers," History of Photography 14.4 (1990): 328.
} 
and Great Slave Lake, down the Mackenzie to Fort McPherson on the Arctic Circle. The photo-series includes views of river travel in the North, the various HBC and free trader post towns that dotted the Mackenzie basin, and images of northern inhabitants. While there was a sizeable non-Aboriginal population north of Edmonton, many of Mathers' photographs are of the indigenous peoples of Denendeh, the area meaning 'our land' that comprises most of the Mackenzie basin. Here were the Dog-Rib (Tli Cho), Slavey (Deh Gah Got'ine), Chipewyan (Denesuline), and the Yellowknife (T'atsaot'ine) peoples. Further to the north, an Inuit group whom the fur traders called the Loucheaux Esquimaux (Gwich'in) encountered Mathers at the farthest point of his travel from Edmonton. Many other Native people not indigenous to the particular area are also depicted in the image sets. Catholic French-speaking Métis from Red River were present, and Beaver (Dunne-za) and Sarcee (Tsuu T'ina) people were working and living north of their traditional lands. Finally, in great numbers were the people who contemporary Euro-Canadians called 'half-breeds.' Sometimes called 'country-born,' or 'Iroquois,' these children of European fur traders and Native women are referred to in this thesis as métis.

In the late 1970s, historian John Foster explained that the term 'Métis' was surrounded by confusion even before 1870 , not least because it had different connotations outside of the Hudson's Bay trading region: with fewer blood-line associations, in the St. Lawrence it meant "trader-broker." 8 The problem of categorization, before the postcolonial critique of 'categorization' itself assumed throughout this thesis, was particularly evident in the Far North: what of the "Cree-speaking, Roman Catholic, 'Iroquois' trapper-hunters?," Foster queried, citing that 'Iroquois' was a pejorative term

\footnotetext{
${ }^{8}$ John E. Foster, "The Métis: The People and the Term," Prairie Forum 3.1 (1978): 79.
} 
similar to 'half-breed.' The problem of usage for historians, as Foster saw it, owes to an indistinct difference of origin between frontier and metropole. Most historians encounter the terms 'Indian,' 'métis' and 'half-breed' in documents created in colonialist metropoles such as London, Montreal, or Toronto, which occluded an understanding of the hinterland meanings of the terms, according to Foster. "A basic premise in elaborating a hinterland perspective for the pre-1870 West," he postulated, "is that the importance of the fur trade lay as much in the changing ways of life of the participants as it did in the commercial and political processes by which the metropolis extended and elaborated its interests in the hinterland." It is true that 'changing ways of life' forged a certain collective identity for many métis people: "a racial term for anyone of mixed Indian and European ancestry," according to the Métis National Council. ${ }^{10}$ I use the small ' $m$ ' throughout this thesis because I share the concern of historians Jacqueline Peterson and Jennifer Brown that, "dual usage (Métis/métis) would be to take it upon [oneself] to decide who belongs to socio-political categories that are still subject to redefinition and evolution." Although seen as lower-class (because of their Aboriginal blood) by non-Aboriginal society and barred from upward social mobility in the late nineteenth century, many métis men were looked upon more favourably as labourers than 'full-blooded' Natives. Consequently, it was not uncommon in the Northwest to find river teams made up of métis paddlers who had family in Glasgow, like the men who travelled north with Mathers in 1901.

\footnotetext{
${ }^{9}$ Foster, "The Métis: The People and the Term," 90.

${ }^{10}$ Jacqueline Peterson and Jennifer S.H. Brown, eds., The New Peoples: Being and Becoming Métis in North America (Winnipeg: The University of Manitoba Press, 1985), 6.

"Peterson and Brown, eds., The New Peoples: Being and Becoming Métis in North America, 6.
} 
In 1903, Mathers published a short story in the prairie newspaper, the Farmers' Advocate, where he described his trip to the Far North. His photographic narrative and accompanying text are presented mostly as a descriptive documentary of his voyage: like the very future of Canada the photographer was drawn north by the downriver current. Though he observed scant fidelity to any actual chronology and geography in his relation of the trip, the transfiguration of space that Mathers' voyage occasioned was sure. Cole Harris has interpreted that the, "conquest of distance, partial as it was, was at once a central motor of colonization, enabling an immigrant society to impose its ways; and of modernization, facilitating the spatial economies, disciplinary tactics, and many of the assumptions of advanced industrial societies." 12 To be sure, Mathers' story, his photographs and his journey rested as much in the narratives they overlapped as in the new dynamics of power they sought to convey. Because narration suggests an expression of movement through both time and space, these images were able to reveal much of what the North was expected to be and expected to provide. Travellers to the North connected their voyages to geographic reference points and historic predecessors as much as they identified the modernizing aspect of their voyages and the changing distances and spaces they traversed.

\section{Distance}

As we have seen in Chapter 3, travellers heading northward not only left Edmonton geographically, but also left the late nineteenth century temporally, venturing into a more 'authentic' world still dominated by a secure history and the ghosts of people such as Alexander Mackenzie, where, according to Ernest Thompson Seton, "the red man

\footnotetext{
${ }^{12}$ R. Cole Harris, The Resettlement of British Columbia: Essays on Colonialism and Geographical Change (Vancouver: UBC Press., 1997), 161.
} 
roamed and hunted, unchecked by fence or hint of white man's rule."13 They sought out the experience of running into the 'heathen' and hostile Natives as had other early British explorers such as Samuel Hearn. Understandings of space also altered as travellers went north; formerly great distances made meaningless by trains assumed monolithic proportions while drifting down the shallow rivers of the District of Athabasca. Days grew longer and distances from post to post increased, the size of trees shrank and eventually disappeared, the weather grew colder. The difficulty of travel in the North was written into every aspect of the environment.

The sense of endurance, distance, and trial that the photographer undertook was not unique to Mathers. James Ryan points out that many commercial photographers of the nineteenth century understood themselves both as noble scientists and as adventurous artists, who vaunted their journeys as much as they did their photographs. ${ }^{14}$ Humphrey Lloyd Hime, the photographer who accompanied Henry Youle Hind on the Province of Canada's Assiniboine and Saskatchewan Exploring Expedition in 1858, was both a professional photographer and a surveyor. ${ }^{15}$ Some saw themselves as romantic cavaliers, like Calgary photographer W.H. Boorne who described himself as a "knight of the camera" among "the savages of the Far West."16 Others, like Whitney and Pike, saw themselves as hunters first and photographers second, but the end result was often the same. Adventuring photographers presented themselves, and were seen as, bridges between two different worlds. In the 1890 s and early 1900s, the photographic audience

\footnotetext{
${ }^{13}$ Ernest Thompson Seton, The Arctic Prairies: A Canoe Journey of 2,000 Miles in Search of the Caribou; Being the Account of a Voyage to the Region North of Aylmer Lake (Toronto: William Briggs, 1911), xv. ${ }^{14}$ Ryan, Picturing Empire, 45.

${ }^{15}$ Ralph Greenhill and Andrew Birrell, Canadian Photography, 1839-1920 (Toronto: Coach House Press, 1979), 84.

${ }^{16}$ W.H. Boorne, "Among the Savages of the Far West," The Canadian Photographic Journal 2.11-12 (1893): 372.
} 
responded to these romantic ideas of civilization and savagery, luxury and hardship, nonAboriginal and Indian, because they were unsure of the direction modernity was taking. In early June, 1901, Mathers left Edmonton with William Connor, a free trader operating in the Mackenzie basin. He began his photograph-making voyage by making an innocuous commentary on a bumpy path. The comment was characteristic of the difficulty of the river voyage 2,000 miles north of his home, and conveyed that one of the central meanings of the trip would be how it was accomplished. "It was decidedly bad," declared C.W. Mathers of the Athabasca trail connecting the growing metropolis of Edmonton to the landing on the river 100 miles north. ${ }^{17}$ Mathers opened his mostpublished version of $A$ Souvenir from the Far North with an image depicting the very impression. [Plate 28] Like FCSC, the popular Edmonton historian J.G. McGregor captured some of the connotations implicit in the famous endeavour of hauling scows upriver: "Tracking a canoe required considerable effort, tracking a York boat upriver was a discouraging ordeal, but tracking a great lumbering box-car of a thing called a scow up the Athabasca was a man-killing job."18

As the harshness of space increased the further the expedition travelled from Edmonton, the physical difficulty of travel and the mechanical difficulty of acquiring images increased in turn. Always the careful businessperson, Mathers' textual captions and published narrative worked to establish this kind of referential connection that he probably hoped would increase the value of the photographs. He recorded that, "In order to get the photographs we found we had to follow the natives' example and stay up all

\footnotetext{
${ }^{17}$ C.W. Mathers, "A Trip to the Arctic Circle," Alberta Historical Review 20.4 (1972): 6. A complete reprint of the 1902 article, C.W. Mathers, "A Trip to the Arctic Circle," The Farmer's Advocate 13.21 (1903): 1212.

${ }^{18}$ J.G. MacGregor, Paddle Wheels to Bucket-Wheels on the Athabasca (Toronto: McClelland and Stewart Limited, 1974), 105.
} 


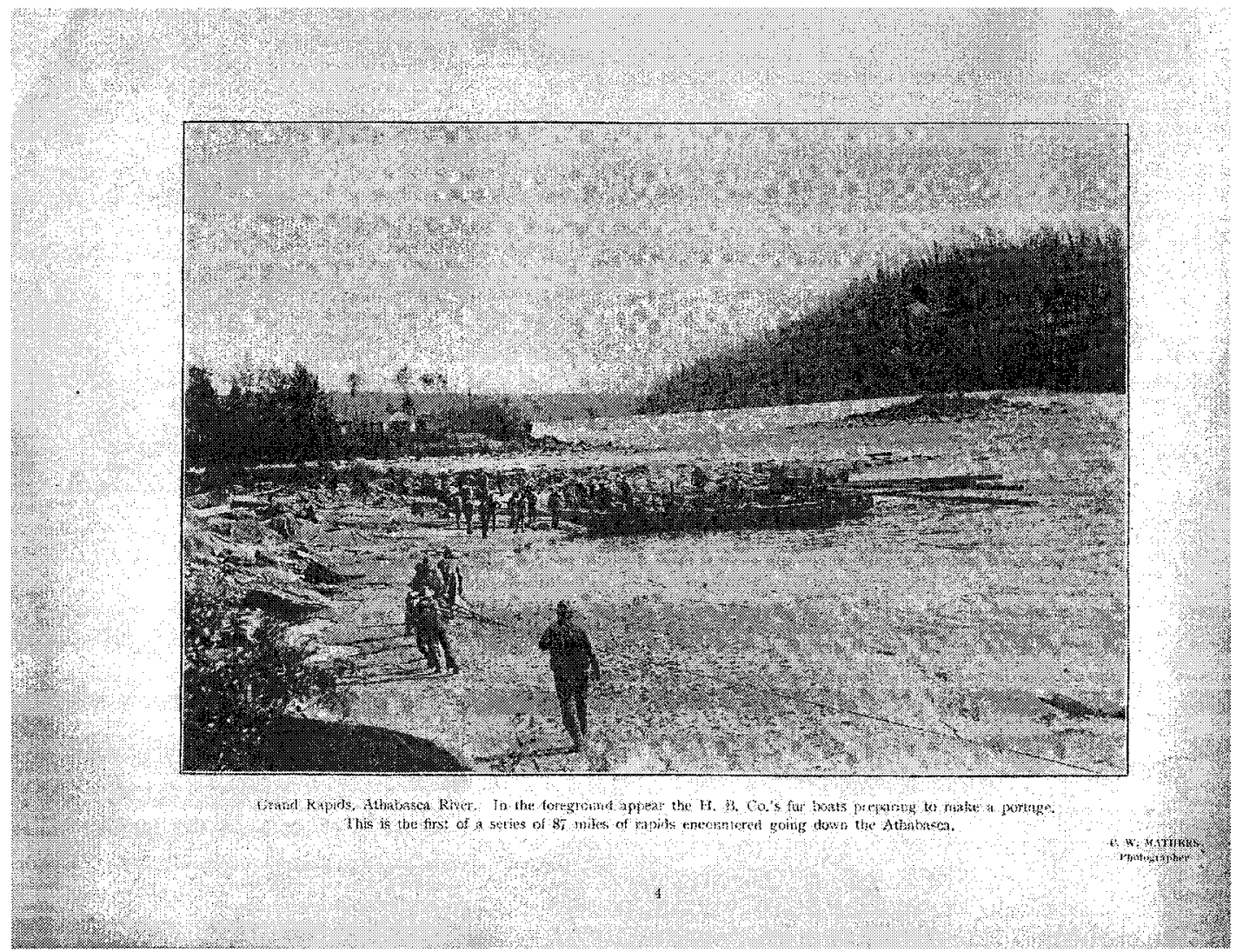

\section{Plate 28: Grand Rapids, Athabasca River}

Source: C.W. Mathers, The Far North: A Souvenir From the North

(Edmonton: C.W. Mathers, Minister of Agriculture, 1901), 4. 
night and sleep in the day time." 19 In this respect his efforts matched the way Whitney, Russell, and Pike had made an exotic construction of the buffalo recognizable and exciting for popular audiences by giving it the mythical values of the North. While Whitney and Pike 'authored' the buffalo in a way that extolled their abilities as hunters, and likewise Russell as scientist, Mathers entered the North with his authority to see and describe vested in his role as photographer. Although obviously not the first to make photographs of the Athabasca-Mackenzie river system, Mathers was certainly the first commercial photographer to visit the region and the first person to travel there explicitly to make images, and his souvenir book came close to becoming the official record of the northern route.

Mathers had help in gaining the authority to represent the North however. Frank Oliver, editor of the Edmonton Bulletin, assured the validity of the northern prints by claiming that Mathers' "reputation as a photo artist is a sufficient assurance that they will do justice to the subject." ${ }^{20}$ The power of the professional photographer over the representational record was challenged by introduction of the 'you push the button and we do the rest' Kodak roll-film camera by George Eastman in 1888. Technical knowledge alone no longer determined a photographer's professional status. Like other photographers of the era, Mathers meticulously indexed, labelled, and copyrighted his photographs. $^{21}$ In an effort to distinguish themselves from untrained 'amateurs,' commercial and professional photographers began to locate the validity of their trade in

\footnotetext{
${ }^{19}$ C.W. Mathers, The Far North: A Souvenir from the North (Edmonton: C.W. Mathers, Minister of Agriculture, 1901), 2.

${ }^{20}$ Edmonton Bulletin 16 September 1901: 2.

${ }^{21}$ Evidence of the importance Mathers placed in this respect is given in that he left an uncannily detailed description to an assistant on the proper techniques to follow in photo-engraving. Most commercial and stock photographers used engraving to claim copyright, index their images, and promote themselves. E. Brown Collection (PAA) PR1965.124 file.3, C.W. Mathers, "Directions to Photo Engraving," 18 September 1894.
} 
the compositional and aesthetic values of the images. As a corollary, George Gilson's Toronto-based Canadian Photographic Journal even offered 'Certificates of Proficiency' to professionals closing their ranks against the 'Kodak fiend.,'22

Mathers qualified himself through the use of similar professional attributions. In the same studio window advertising the sale of Kodaks, he displayed the ribbons for his first and second prizes at the 1895 Territorial Exhibition in Regina for photographs taken on 'Aristo' paper and the 'Collection of 12 Views' competitions. ${ }^{23}$ By the time he left on his voyage for the North, Edmontonians were convinced of Mathers' professional status, having seen the two souvenir albums he made celebrating agriculture and industry in Edmonton. He had also made previous photographic excursions to the Rocky Mountains, travelled by rail south to Calgary, and in the same year (1898) taken the 100 mile wagon road north to Athabasca Landing. Noting Mathers' well-established record by the time he undertook the 1901 expedition, the Bulletin guaranteed Edmontonians that his photographs would be, "the only views taken in the north country by a professional photographer using the latest and most complete appliances." 24 As a professional, Mathers was sensitive to his role as scientist and artist in rendering the North, and was aware of allusions his voyage had to the adventurous documentary photographer. His most important shots come only after a long period spent enduring the challenges presented to the photographer: the rapids, the portages, and especially the locals.

\footnotetext{
${ }^{22}$ In 1892, on the eve of the World's Columbian Exposition in Chicago, Gilson and colleagues were rather concerned that the "Kodak fiend" will have a decided advantage over the 'fiend" with a glass plate camera, or even over the one using cut films." Although it was generally assumed that there would be a discrimination against film cameras, in a series of personal communications with the exhibition's organizers George Eastman settled the dispute by citing the admission fees - proving that "the Kodaker's two dollar bill is just as good as any other mans. [sic]" George Gilson, "Kodaks at the World's Fair," The Canadian Photographic Journal 3.9 (1892): 272.

${ }^{23}$ Silversides, "Charles Wesley Mathers," 5.

${ }^{24}$ Edmonton Bulletin 16 September 1901: 2.
} 


\section{Photographing the 'Other'}

Many Euro-Canadians interested in the North and conscious of these hardship narratives also understood adventuring photographers as depicting another world which reflected what they perceived as the rugged qualities of white masculinity. Sherrill Grace adds that historians must not forget that, additionally, "a form of white Nordic supremacy underpins much of the praise of North as a land of spiritual purity." 25 Indeed, Charles Mair felt that his 1899 voyage to the District of Athabasca had taught him that the 'supreme race' born in "Scandinavian snows ... must be recreated in the high latitudes which gave it birth." 26 This conversely reflected a deep fascination with the 'uncivilized' and 'savage' Native people of the sub-Arctic - whose northern origins had apparently done nothing to raise them up civilization's scale. As northern voyagers moved further into history, the presence of Natives seemed to indicate that they had moved further away from civilization and the realm of 'industrial man'. ${ }^{27}$ Such contradictions went unnoticed by adventurers in the North, who preferred to obsess over the simplified vision that formed the pretext of their voyages. Voyaging into the North meant travelling into the past in order to see the future. It meant conquering long distances and harsh environments, qualities epithets such as 'the Barren Lands' or 'the Far North' sought to capture. This North, to Edmontonians and the popular imagination of the rest of western civilization, relied on keeping these narratives intact. The Athabasca-Mackenzie river basin, in a way, was a land of contractions: historic romanticizing predicted a modern

\footnotetext{
${ }^{25}$ She specifically indicts Lawren Harris and a number of other mid twentieth-century Canadian artists. Grace, Canada and the Idea of North, 73.

${ }^{26}$ Charles Mair, Through the Mackenzie Basin: A Narrative of the Athabasca and Peace River Treaty Expedition of 1899 (Toronto: William Briggs, 1908), 149.

${ }^{27}$ Mair, Through the Mackenzie Basin, 148.
} 
future; 'savage' Natives lived in the cradle of the 'White race'; visions of technological progress and rugged masculinity reinforced the other but were always at war.

Contrary to the hostile persona given to Native peoples of the Far West in the middle part of the nineteenth century, Native peoples in the later part of the same era were seen as part of a 'vanishing race. ${ }^{28}$ The possibility that photography offered to recapture these experiences was what Mathers capitalized on. In many ways this was the same imperative that anthropologist Renato Rosaldo has called imperialist nostalgia: "where people mourn the passing of what they themselves have transformed."29 To others, however, Mathers' photographs of Natives were a reflective celebration of their pacification and disappearance. As Alan Trachtenberg explains, "Ethnology and entertainment kept Indians at a distance defined by 'otherness,' 'their' way of life moribund, their demise taken as proof of the triumph of 'our' civilization. Testimony of need for such proof lay in the incalculable number of photographic images of Natives produced at the turn of the century." 30

The widespread belief that Natives would soon be gone - that is, extinct or assimilated - quickly led to a desire to take the valuable 'last shot' of authentic Indian behaviour. Mathers' earlier employer, W.H. Boorne, epitomized the perversity of the craze. After a description of how he fought and cheated his way into a closed sun-dance in the $1880 \mathrm{~s}$, Boorne chided the in-authenticity of the amateur through the value of his photograph. "Nine braves were tortured that day," he claimed, "and this I believe was the last genuine 'sun-dance' held by the Indians in the North West. All the old customs are

\footnotetext{
${ }^{28}$ Christopher M Lyman, The Vanishing Race and Other Illusions: Photographs of Indians by Edward S. Curtis (New York: Pantheon Books, Smithsonian Institution, 1982).

${ }^{29}$ Renato Rosaldo, Culture \& Truth: The Remaking of Social Analysis (Boston: Beacon Press, 1989), 69.

${ }^{30}$ Alan Trachtenberg, Shades of Hiawatha: Staging Indians, Making Americans 1880-1930 (New York: Hill and Wang, 2004), 170.
} 
gradually dying out, and to-day the happy photographer and possessor of the omnipresent 'Kodak' can easily overcome the scruples of the majority of the noble red men with the almighty dollar." 31 Mathers no doubt shared this view, as he sold Boorne's 'last sundance' image in his own souvenir books. Many more of the images he made during his time in Edmonton are suggestive of this mentality. While a large number of Mathers' photographs of Natives were taken in carefully constructed studio scenes, 'A170 Assinatappi, Sarcee Indian and Squaw' shows that Mathers actively sought out Native men and women willing to pose for his camera. [Plate 29]

As technological advances at the end of the nineteenth century made the camera more versatile, photographers scrambled to be the first to capture certain views; or, alternatively, the last to capture views that would never be seen again. The combination of the versatility of the camera and the quest for authenticity both enabled and compelled Mathers to go north. Understanding the photographer's commercial intentions shows us that Mathers' voyage was presented as the recovery of this authentic experience something that could not be found in Edmonton. For this reason, Mathers' river voyage articulated the divide between Edmonton and the North in order to pronounce and reinforce the distinction between 'real' Natives and inauthentic ones.

Paige Raibmon has asked what purpose this ordering of authentic and inauthentic has served. She posits that nineteenth-century values and European perceptions of Native peoples operated along axes such as 'inauthentic and authentic,' that matched

\footnotetext{
${ }^{31}$ Boorne took the photograph at a Blackfoot camp in 1887. Despite the disruption his camera caused at the ceremony, Boorne claimed, "I was particularly anxious to get a shot at the 'torture', which I was informed had never been actually photographed." Although Boorne tells readers in the Canadian Photographic Journal that he took the picture 'last year' in 1892, the article was probably written before the 1893 publication since the original caption reads "Boorne and May, 1887." E. Brown Collection (PAA) PR1965.124 vol.190, "Photographs of Indians," \#55; Boorne, "Among the Savages," 372.
} 


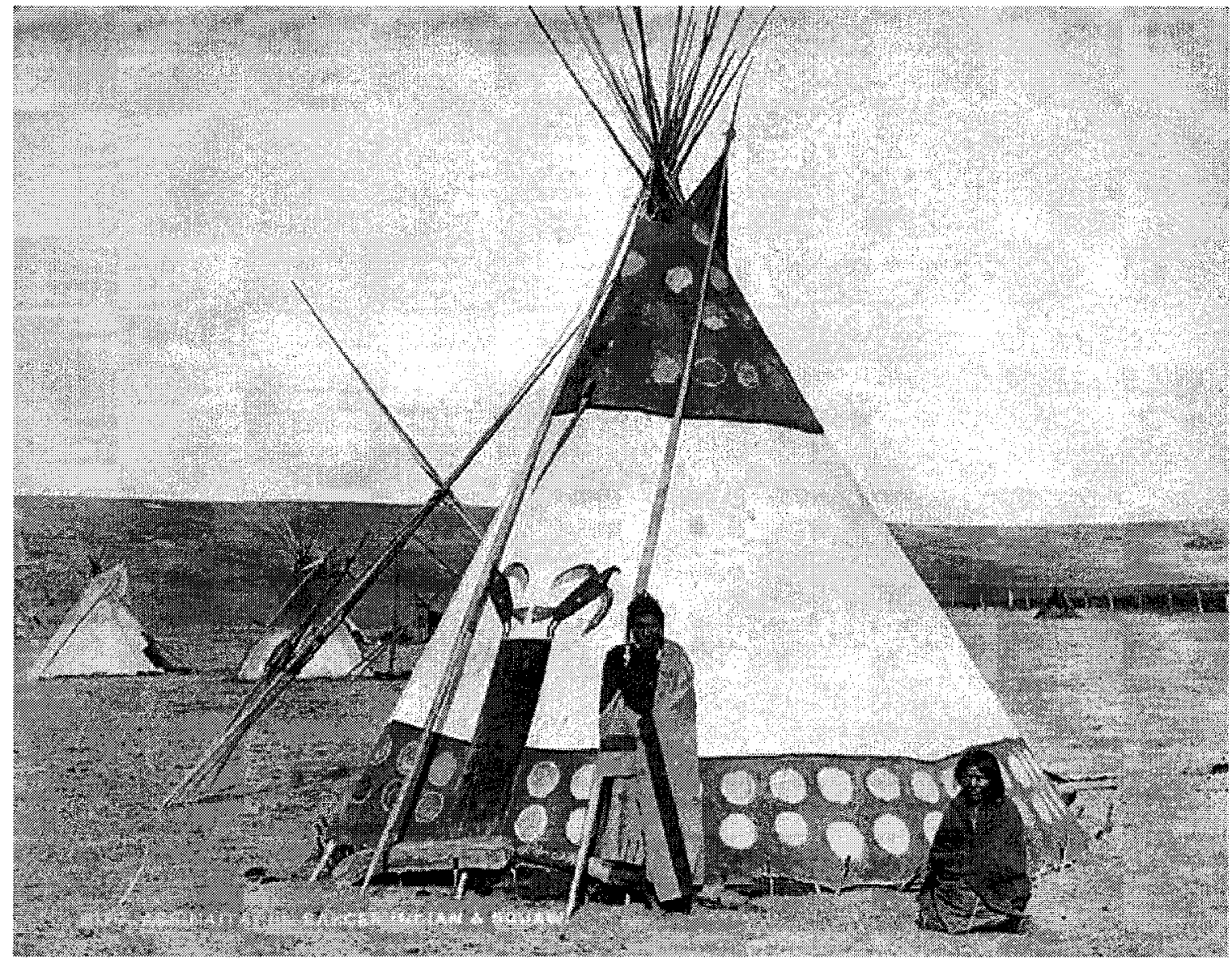

Plate 29: Portrait of Sarcee Indian Assinatappi and His Wife

Source: C-006934 Canada. Department of Indian Affairs and Northern Development Collection (LAC) 1961-018 NPC 
'civilization and savagery', 'white and other', 'modern and traditional' and did not exist in closed binaries. They actually explain and reinforce one another, yet are "neither absolute nor without opposition."32 Mathers' voyage seemed to unfold through a sequence of places and narratives that reinforced these binaries, projected along the corresponding line of a spatial arc that began in Edmonton and ended at the Arctic Circle. In exploring the frontier, Mathers chronicled the transportation of manufactured goods into the North, celebrating the trade network of the HBC. Although all of the photographs he had taken during the 1890 s depicted Native people outside of industrial society, sitting in front of skin houses or posing resolutely in a studio-forest scene, these images found Natives at work and occupying a central place inside the early industrial network. He was fascinated with the strength of the Native and métis packers he saw at the Grand Rapids north of Athabasca Landing, and was insistent on the premise that these people were somehow natural labourers: "I saw one of them packing an ordinary No. 8 cook stove, and another - a small, skinny individual - walking off with a barrel of sugar."33 [Plate 30] As Paige Raibmon has shown in her analysis of Native labour in the hop fields of western Washington, the 'authentic' Native could still be romanticized as industrial worker and not hinder the 'civilized' belief that the race was disappearing. Raibmon adds that these Euro-Canadian assumptions often "legitimated colonial assertions of superiority and control,"34 and here we must return to Mathers' image 'Tracking up the Athabasca River.' Although the tracking photograph was created near the end of his journey, Mathers always placed this and other tracking images at the

\footnotetext{
${ }^{32}$ Paige Raibmon, Authentic Indians: Episodes of Encounter from the Late Nineteenth-Century Northwest Coast (Durham: Duke University Press, 2005), 7.

${ }^{33}$ Mathers, "A Trip to the Arctic Circle," 8.

${ }^{34}$ Raibmon, Authentic Indians, 116.
} 


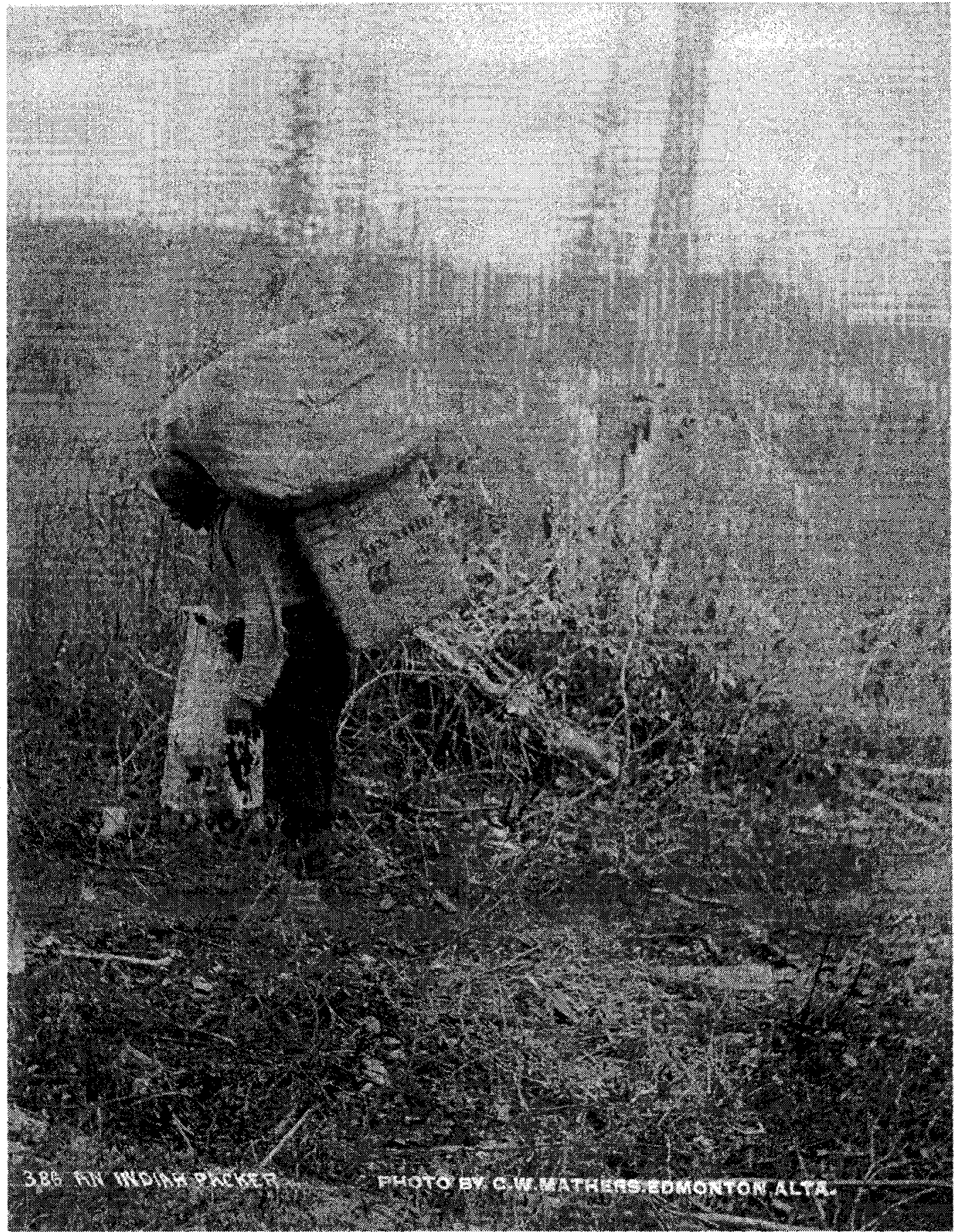

Plate 30: 386 An Indian Packer

Source: PA-0124041 Minnesota Historical Collection (LAC) 1963-092 NPC 
beginning of his souvenir books, as if to narrate that Native labour provided access to and 'opened' the North. [Plate 31] Photographs associated with Euro-Canadian or nonAboriginal means of transportation, like the steamer, were never associated with Native people. Even though almost all riverboat captains in the North were métis or Cree, owing to an ability to successfully navigate the shallow river which the non-Aboriginal people did not share, none of Mathers' images chronicle these men.

As Mathers continued north, he became increasingly interested in the Chipewyan people labouring along the Slave River, and in particular the Slavey and Dog-Rib Natives in William Connor's trading outfit. Brock Silversides suspects that Mathers may have been prompted to travel to the North by the notorious reputation William Connor had garnered himself. ${ }^{35}$ When Connor returned to Edmonton for the summer of 1900 , he startled city residents arriving in the company of three Slavey men. The Edmonton Bulletin reported that, "they are the first Slaveys who ever visited Edmonton, and the wonders of civilization are a revelation to them. ${ }^{\prime 36}$ Equating city life with morality, the Bulletin imagined that "their ideas of the whiteman's mode of living as they see it here is highly edifying." 37 For Edmontonians, here was 'the other' arriving to reflect the values of the centred European subject: the Slaveys apparently believing that the nonAboriginals all lived in one big house "like ducks in a row." The appraisal the Bulletin made from what the editors perceived as the Slaveys' domestic vision must not be overlooked. Understanding how the visual order of domesticity provided a vessel for other narratives and assumptions helps explain Mathers' photographs of the North, since

\footnotetext{
${ }^{35}$ Brock V. Silversides, "Charles Wesley Mathers," in C.W. Mathers' Vision, ed. Brock V. Silversides and Provincial Archives of Alberta (Edmonton: Provincial Archives of Alberta, 1989), 11.

${ }^{36}$ Edmonton Bulletin 6 April 1900: 6.

${ }^{37}$ Edmonton Bulletin 6 April 1900: 6.
} 


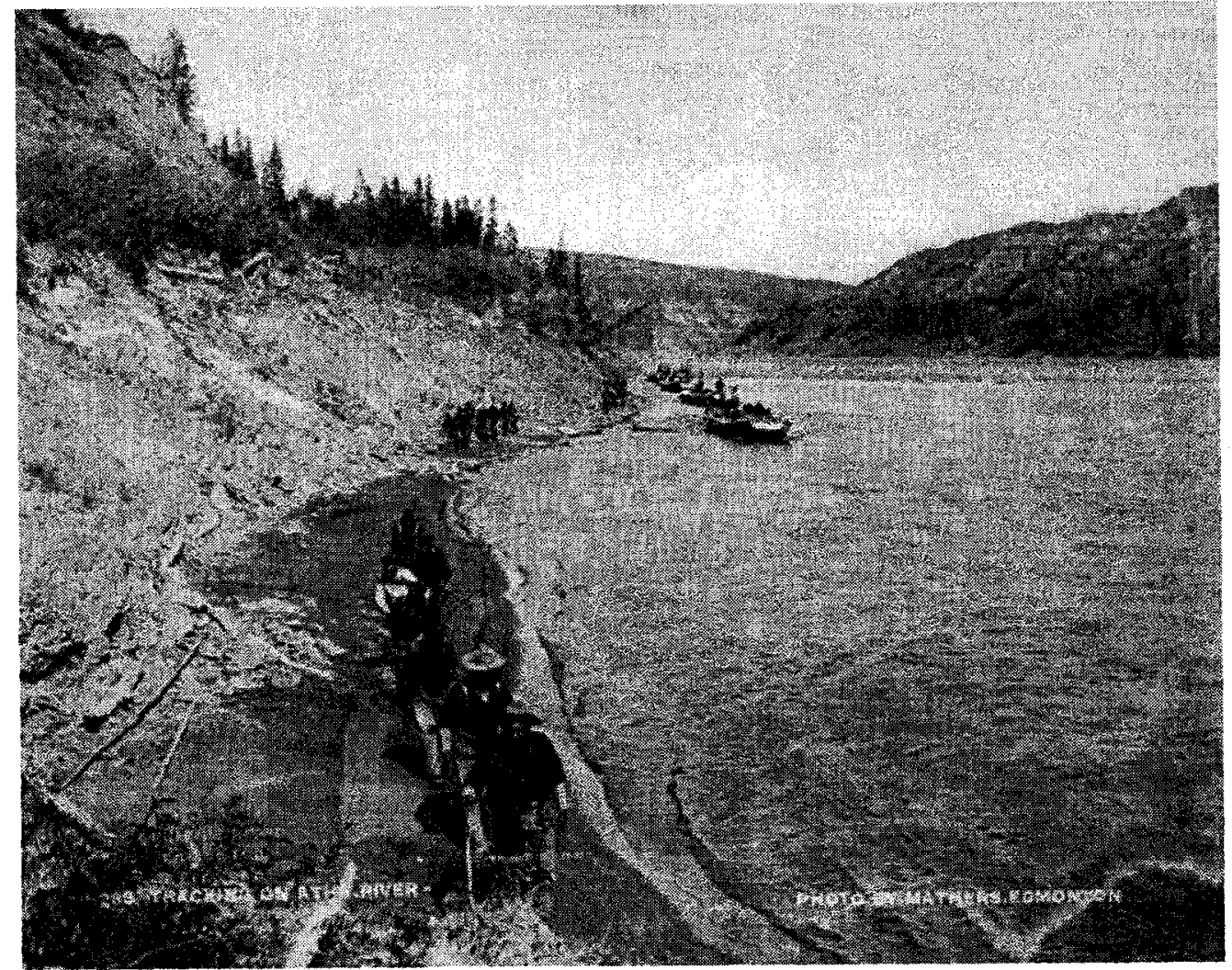

Plate 31: 288 Tracking on Atha. River

Source: C-00690 Ernest Brown Collection (LAC) 1947-009 NPC 


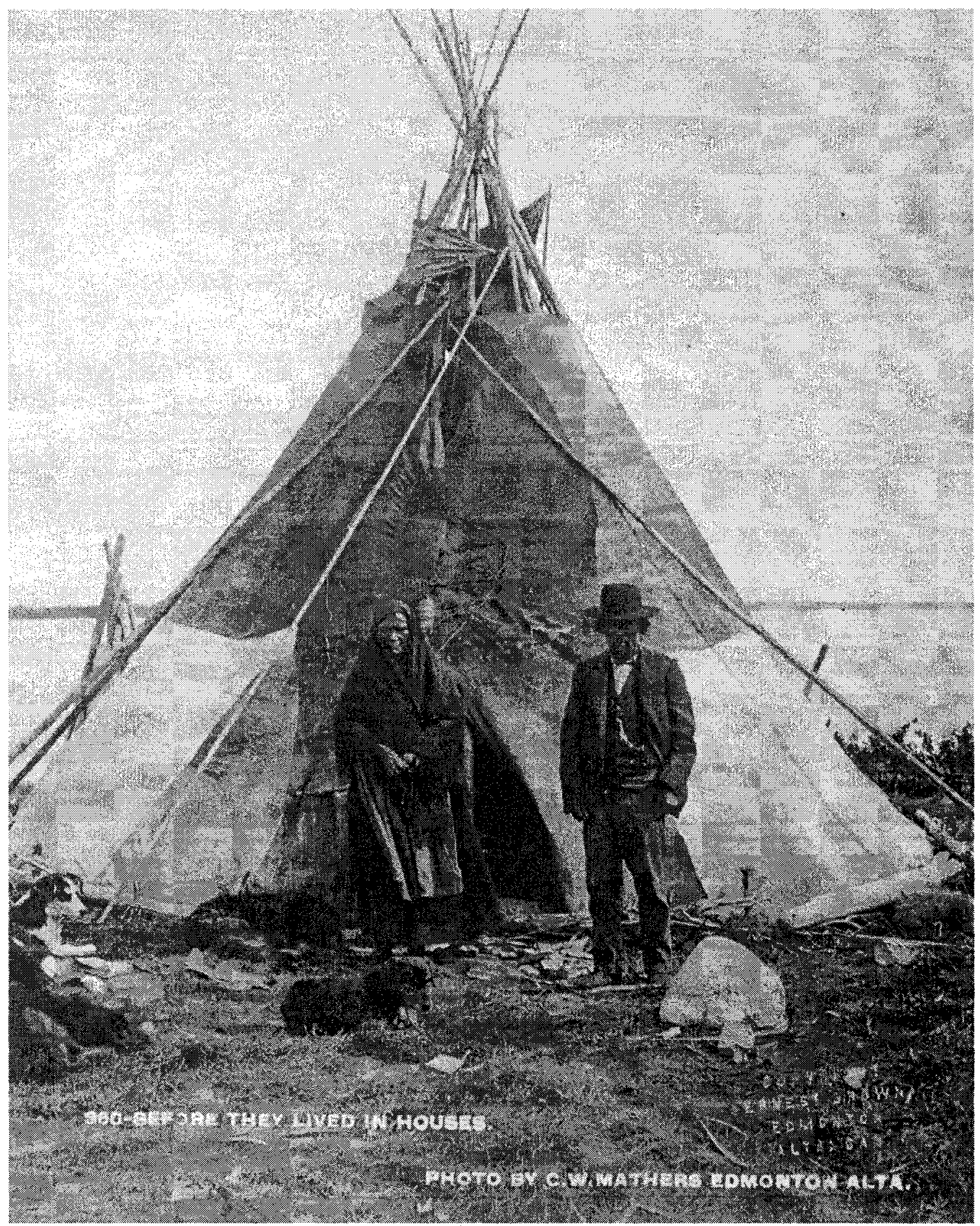

Plate 32: 360-Before they lived in Houses

Source: C-004991 Ernest Brown Collection (LAC) 1947-009 NPC 
he recorded a number of domestic-themed photographs to help Edmontonians 'gaze' and make meaning of the North.

Adele Perry describes housing as both a mirror and a window, arguing that the perception of order and discipline in Euro-Canadian homes rested largely upon the perceived disarray of Native dwellings. ${ }^{38}$ Nineteenth-century domestic discourse revolved especially around the idea of hygiene, as any statements concerning the 'cleanliness' of a dwelling was also a moral statement upon its inhabitant. As the editor of the Bulletin imagined Slavey Indians celebrating the 'highly edifying' character of Edmonton houses, Mathers was in turn fascinated with the vice and low morality he perceived in the indigenous 'skin huts.' The more 'authentic' Natives, portrayed in Mathers' 'Before they Lived in Houses,' [Plate 32] stand in marked contrast to the more'civilized' but less authentic figures standing in front of a sturdily-constructed log cabin in 'A Well To-Do Native Couple' 39 The logic of colonialism thus implicated a racist ordering of class: for Natives, to become prosperous meant being seen as associated (though never entirely) with Victorian 'moral' domesticity, but to be viewed by many Euro-Canadians as a non-authentic Indian. One need only notice the man's watch-chain and European clothing of the couple in 'Before they Lived in Houses' to register the contradictions of the domestic order.

The visual order of the nineteenth century made this possible, since the indexicality of a photograph guaranteed not only the untrammelled deliverance of truth, but also the moral weight that the subject of the photograph possessed. In an article sent to the Canadian Photographic Journal in 1894, the Anglican missionary Reverend P.L.

\footnotetext{
${ }^{38}$ Adele Perry, "From 'the Hot-Bed of Vice' to the 'Good and Well-Ordered Christian Home': First Nations Housing and Reform in Nineteenth Century British Columbia," Ethnohistory 50.4 (2003): 593.

${ }^{39}$ E. Brown Collection (PAA) PR1965.124 vol.191, "The Far North," \#35, \#37, \#88.
} 
Spencer disparaged that readers enjoy the work of photographers of the Barren Lands of the 'extreme north west' who entertain "opportunities for studying the life of the red-man in his native seclusion and primitive simplicity. ${ }^{, 40}$ Photography, suggested Spencer, should be used to show the "employments of the natives, and the prospects for civilized labor and commerce," made possible by the Canadian missionary. ${ }^{41}$ Spencer submitted a series of prescriptive articles explaining exactly how photography could bring Native men into the industrial fold. ${ }^{42}$ Beginning with images of Natives using a threshing machine outside the 'Old Mohawk Church' in Brantford, the travelling photographer must visit and record St. Paul's Industrial School outside of Winnipeg. ${ }^{43}$ Photography, argued Spencer, could chart not the erasure of a 'dying race', but the 'dying culture' of a people who, "have had a mysterious history in the past, occupy at the present time an interesting and remarkable position in the social vista, and are certain to exercise in the future no little influence for weal or woe in the formation of a Canadian nation."44 Implicitly tied to domesticity, this future involved industrious Natives, "settled on reserves not very remote from the track of the iron horse. $" 45$ Not unlike Mathers, Spencer connected travel to the far reaches with a type of movement through increasingly exotic terrain - and by the time he reached Calgary the logic of an industrial future for Canadian Natives was forgotten enough that his story turned to touring through the Sarcee reserves with his paying money for the chance to capture their last ceremonies on film. ${ }^{46}$

\footnotetext{
${ }^{40}$ Spencer, "The Camera in the Mission Field," 207.

${ }^{41}$ Spencer, "The Camera in the Mission Field," 206.

${ }^{42}$ Perry, "From 'the Hot-Bed of Vice'," 596.

${ }^{43}$ Spencer, "The Camera in the Mission Field," 208, P.L. Spencer, "The Camera in the Mission Field: The North West," The Canadian Photographic Journal 4.2 (1895): 123.

${ }^{44}$ Spencer, "The Camera in the Mission Field," 208.

${ }^{45}$ Spencer, "The Camera in the Mission Field," 207.

${ }^{46}$ After arriving at the Sarcee Reserve outside Calgary, Spencer recounted his encounter with the wellknown Chief Bull's Head: "Being very desirous of obtaining a likeness of the dark-faced patriarch, I asked
} 
Following the work of Edward Said, Kim Greenwell affirms that Spencer's narrative and

views towards Natives are not an atypical missionary experience, but a clear indication

that missionary identities were:

defined in opposition to the colonial terrains they imagined. ... Armed only with their 'rhetorical potency' and 'moral sanction,' missionaries produced narratives of Promethean voyages into the always dark, but soon to be illuminated, mission field. These narratives worked to transform, at least in discourse, previously poor, often minimally educated men from the margins of bourgeois society into 'singularly transcendent and historically empowered figures,' ... like the broader colonial enterprise of which it was a part, missionary discourse constantly sought to mediate its own inner ambivalence and inconsistencies $^{47}$

With Mathers' photographs at their command, observers in Edmonton were able to 'mediate' their inner inconsistencies by gazing at photographs of tepees and 'poverty' in the North as evidence of the moral depravity that, in part, made the North so interesting, and read the absence of domesticity as a 'social map' guaranteed by the modern privileging of vision. In large part however, Edmontonians were not interested in the various bands of Dene people living in the sub-Arctic at all. For some, this ambivalence was a result of the sub-Arctic heritage of the Dene people - survival in the

\footnotetext{
Mr. Stocken (the missionary here) to be good enough to introduce me to him and to ascertain whether he would consent to the ordeal." The chief's price for the photograph was $\$ 5$ - meaning $\$ 3$ for him and $\$ 2$ for his dwelling, "inseparably connected for photographic purposes." Carol Williams suggests that shrewdness as such on the chief's part reveals the dislogic of colonialism: the passages reveal Spencer clearly felt that many Natives were 'incompatible' with supporting themselves in modern economies without help and were scared of the camera, but it is the Sarcee here who are profiting from the white superstition of the 'dying race'. Alternatively, Paige Raibmon suggests that explanations like ' $\$ 2$ for the dwelling' reveal the incorporation of European domestic logic into existing tribal hierarchies, proving that Native peoples are not locked into a static tradition but capable of navigating modernity without sacrificing integrity. Spencer refused the price and Bull's Head retired, but after an hour emerged from his tent wearing his royal uniform and allowed the tourists to take their shots for a dollar. P.L. Spencer, "The Camera in the Mission Field: British Columbia," The Canadian Photographic Journal 4.6 (1895): 147; Carol J. Williams, Framing the West: Race, Gender, and the Photographic Frontier in the Pacific Northwest (Oxford: Oxford University Press, 2003), 143; Paige Raibmon, "Living on Display: Colonial Visions of Aboriginal Domestic Spaces," BC Studies. 140 (2003): 89.

${ }^{47}$ Kim Greenwell, "Picturing 'Civilization': Missionary Narratives and the Marigins of Mimicry," $B C$ Studies 135 (2002): 7.
} 
boreal forest was too easily explained. According to Coates and Morrison, nonAboriginal settlers considered tepees, skin-huts, and tents to be 'primitive' examples of modern dwellings, existing on a moral level that deteriorated as distance from the city increased. ${ }^{48}$ Inuit houses, however, constructed of snow or whale bone, fascinated Europeans with both their strangeness and ingenuity. It was with the Inuit of the Arctic Circle that the binaries of difference converged and were upset, sometimes reversing more than once.

Responding to popular sentiment, Mathers was keen to pronounce the difference of the Inuit from the Dene and Cree to the south. Beginning at the Slave River, he began to understand his voyage through the symbolic reversal of the order of the sub-Arctic. As he travelled north down the Mackenzie, Mathers systematically recorded the lengthening of the days until finally arriving in the land of the Inuit, who sleep during the day and "were up during what we called night."49 Photographic captions like "Group of Esquimaux taken at Midnight" are expressive of this posturing. In the 'land of the midnight sun" the river voyageurs were "not long anchored until we saw what we came to see. The Esquimaux in their kayaks." 50 It seemed as though Mathers had somehow rediscovered the aura of authenticity he had once photographed in the Cree and Blackfoot. Before his encounter with the Inuit, Mathers had employed panoramic views of métis and Natives hard at work in the service of trade, as exemplified by ' 314 - Great Slave Lake from Fort Resolution.' [Plate 33] This strategy, however, was abandoned in relation to the Inuit.

\footnotetext{
${ }^{48}$ Kenneth Coates and William R. Morrison, "Winter and the Shaping of Northern History: Reflections from the Canadian North," in Northern Visions: New Perspectives on the North in Canadian History, ed. Kerry M Abel and Kenneth Coates (Peterborough: Broadview Press, 2001 ), 26.

${ }^{49}$ Mathers, "A Trip to the Arctic Circle," 15.

${ }^{50}$ Mathers, "A Trip to the Arctic Circle," 15.
} 


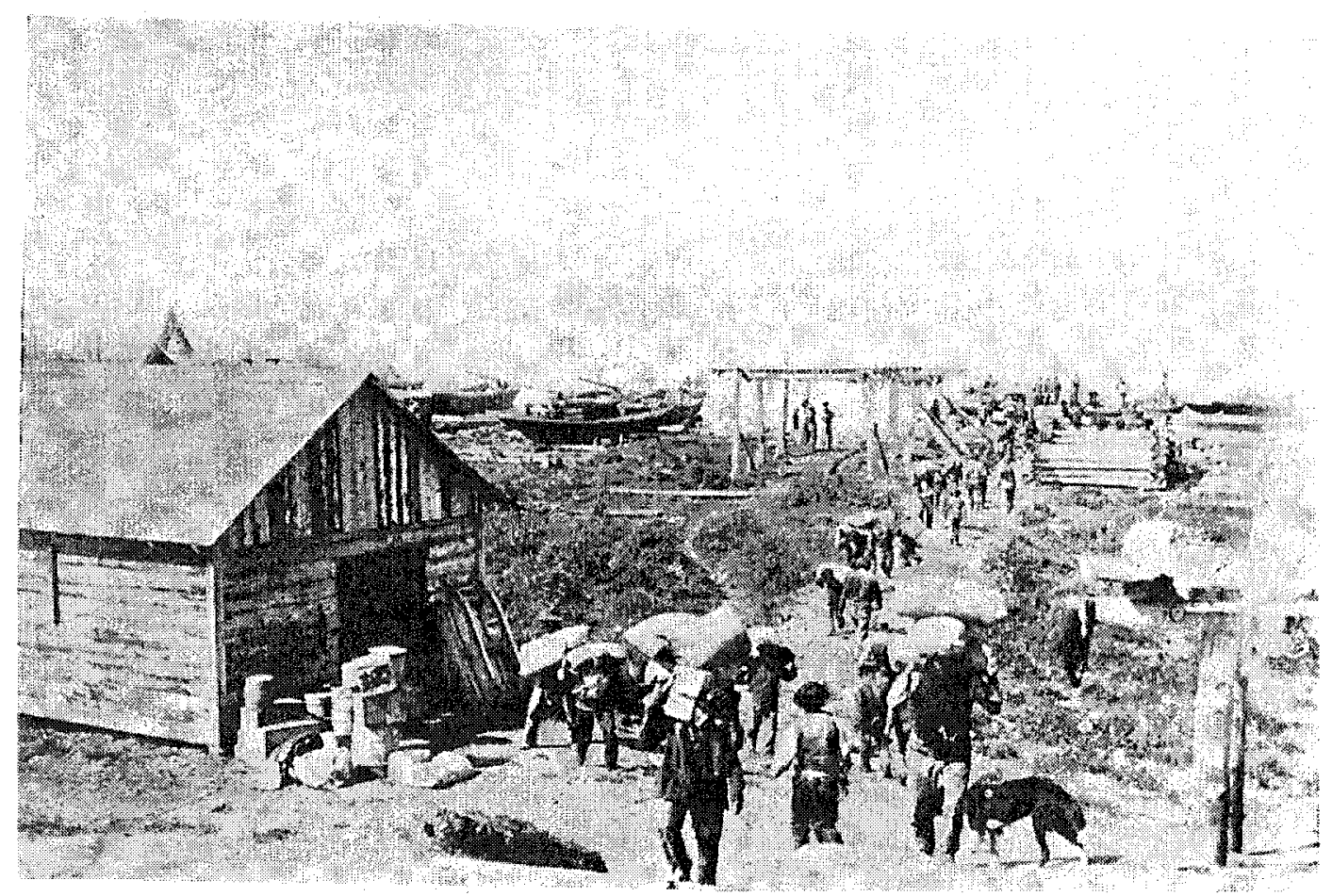

\section{Plate 33: 314 - Great Slave Lake from Fort Resolution [Detail]} Source: PA-146870 Minnesota Historical Society Collection (LAC) 1963-092 NPC 
Once he encountered the Inuit, Mathers returned to the essentialized photography of 'racial types' presented for ethnographic scrutiny, presenting viewers of his souvenir books with the Inuit people of the Arctic deeply situated in their decidedly non-western environs. Accordingly, the first advertisement to run in the Edmonton Bulletin describing Mathers' trip highlighted quite pointedly that, "the Esquimaux were met only at McPherson on Peel river and are the most interesting, not only because they are the most distant and the least known, but because they are most independent of civilized influences and show by far the greatest ingenuity and industry in the manufacture of their tools, utensils and weapons." 51

\section{Indians and Other 'Others'}

Because the Inuit were relatively new to the popular interests of Euro-Canadians, they had to be incorporated into a 'hierarchy of races, ${ }^{, 52}$ organized and exhibited by a nineteenth-century visual culture turning on modern forms of explication. ${ }^{53}$ To Europeans, white civilization stood at the top of this equation, and sliding binaries of 'modern and traditional' or 'active and passive' marked varying categories of nonEuropeans. Métis or 'half-breed' peoples in colonial settings, however, presented a difficult classificatory problem for non-Aboriginals in terms of racial hierarchy: were they 'defective Europeans' or 'perfect Indians'? ${ }^{54}$ The belief in an either/or approach to miscegenation was magnified through multiple layers of social being. Illustrative of how integral racial binaries were to everyday practice, when Commissioner David Laird

\footnotetext{
${ }^{51}$ Edmonton Bulletin 6 September 1901: 1.

${ }^{52}$ Geller, Northern Exposures, 34.

${ }^{53}$ Timothy Mitchell, "Orientalism and the Exhibitionary Order," in The Visual Culture Reader, ed. Nicholas Mirzoeff (London and New York: Routledge, 1998), 293.

${ }^{54}$ Ann Laura Stoler, Race and the Education of Desire: Foucault's History of Sexuality and the Colonial Order of Things (Durham: Duke University Press, 1995), 114.
} 
appeared in 1899 to offer the northern peoples treaty and script, the métis inhabitants were given script if they "lived like" Natives and none if they "lived like" whites. ${ }^{55}$ John Foster has noted that problems of definition as such changed geographically. Dissimilar to other settlements, Foster explains that Laird's Treaty 8 Commission found many "fullblooded" Aboriginal people demanded the "half-breed" script over treaty status. ${ }^{56}$

When faced with the question of 'what' the Inuit were, the Edmonton Bulletin assured readers that, "in appearance they resemble the Japanese much more than they do the Indians and their skill and industry would indicate such a relationship rather than with the Indians. The Esquimaux and Indians have no intercourse whatever. They look upon each other as of different and hostile race. ${ }^{.57}$ On his first journey north in 1887, Father Petitot recorded for dramatic affect the tale of his Dene guide, General Bottom, of a massacre carried out when Inuit surprised his family's camp in the night: "we had hunted and lived with those shaven heads and hoped to soften their hearts and that, I think, shows that we lacked good sense ... they are real wolves whom we shall never tame. They are too wild to live like people." 58 Petitot's confusion only grew as he pondered how "the man who said this was himself what we call a savage." 59 For his part, in 1903 Mathers remembered the Inuit as "fine, greasy, jolly fellows; all dressed in fur ... The Esquimaux are a perfectly uncivilized tribe. ${ }^{, 60}$ In resting their assessment of the Inuit on the mutual resistance of class and race, the Inuit could be successfully 'othered' and respected without challenging non-Aboriginal ideas of superiority - being 'uncivilized'

\footnotetext{
${ }^{55}$ Mair, Through the Mackenzie Basin, 58.

${ }^{56}$ Foster, "The Métis: The People and the Term," 80.

${ }^{57}$ Edmonton Bulletin 16 September 1901: 2.

${ }^{58}$ Emile Petitot, Among the Chiglit Eskimos (Paris, Edmonton: E. Plon, Nourrit et Cie; Boreal Institute for Northern Studies, 1887; 1981), Emile Petitot, Among the Chiglit Eskimos (1881; Paris and Edmonton: E. Plon, Nourrit et Cie, Boreal Institute for Northern Studies, 1981), 24-5.

${ }^{59}$ Petitot, Among the Chiglit Eskimos, Petitot, Among the Chiglit Eskimos, 25.

${ }^{60}$ Mathers, "A Trip to the Arctic Circle," 15.
} 
distinguished them from the Dene, a people no longer exotic. Peter Geller suggests that while photographs of the Inuit definitely intone that they are a 'primitive' people, "they are also hardy and cheerful and resilient and worth admiring: here are the heroic qualities of Inuit lifestyle, of humans against the elements." ${ }^{61}$ [Plate 34] The Bulletin went so far as to consider the moral characteristics of modern visions of appearance in drawing comparison between Mathers' photographs of the Inuit and the much favoured Eastern European immigrants who farmed around Edmonton, claiming that their "dress, made with the fur turned it, does not look unlike the sheepskin sacque of the Galician." ${ }^{\prime 62}$ Alan Trachtenberg has similarly analysed the "importance of imperialism to the meanings registered by the words 'Indian' and 'immigrant," which he argues cannot be separated or stressed enough in understanding where Americans drew the sense of their moral purity against the immigrant from. ${ }^{63}$ That the type of clothing the Inuit wore would have had possible meanings for Canadian nativists in accepting Galicians stresses this point.

The Inuit were seen in 'perfectly uncivilized' clothes as an alternative to the Dene, who wore 'tattered' versions of western clothes. Indeed, for Mathers the very image of 'Poverty,' was the way the Dene people of the sub-Arctic appropriated European materials into the tepee structure instead of using the expected caribou hide. [Plate 35] Though Mathers probably felt the wood-plank door was macabre, it is beyond the scope of this paper to assume what definition of wealth Aboriginal peoples would have drawn from the dwelling.

\footnotetext{
${ }^{61}$ Geller, Northern Exposures, 35.

${ }^{62}$ Edmonton Bulletin 25 October 1901: 1.

${ }^{63}$ Trachtenberg, Shades of Hiawatha: Staging Indians, Making Americans 1880-1930, xx.
} 


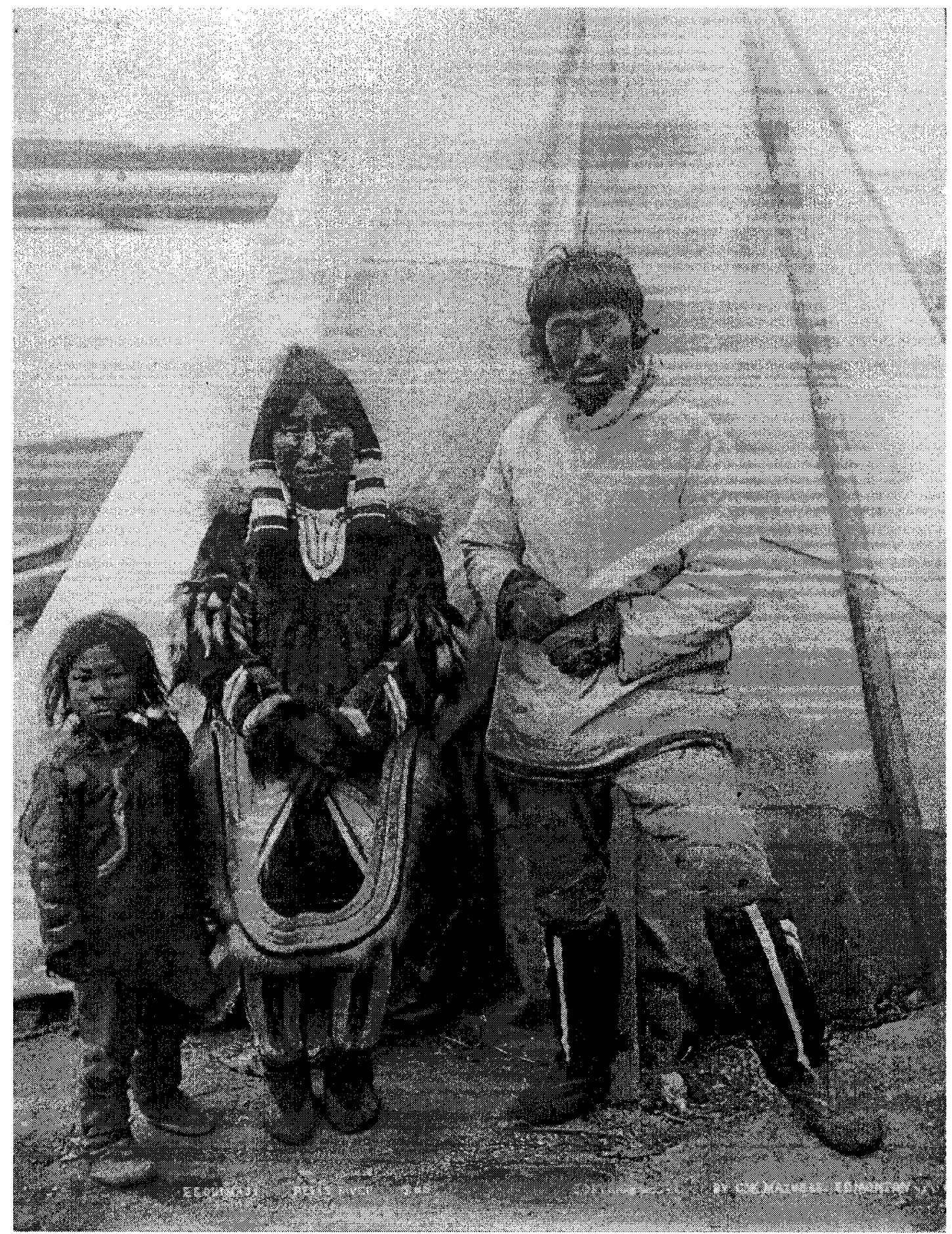

Plate 34: Esquimaux, Peel's River - 269

Source: C-005107A Ernest Brown Collection (LAC) 1947-009 NPC 


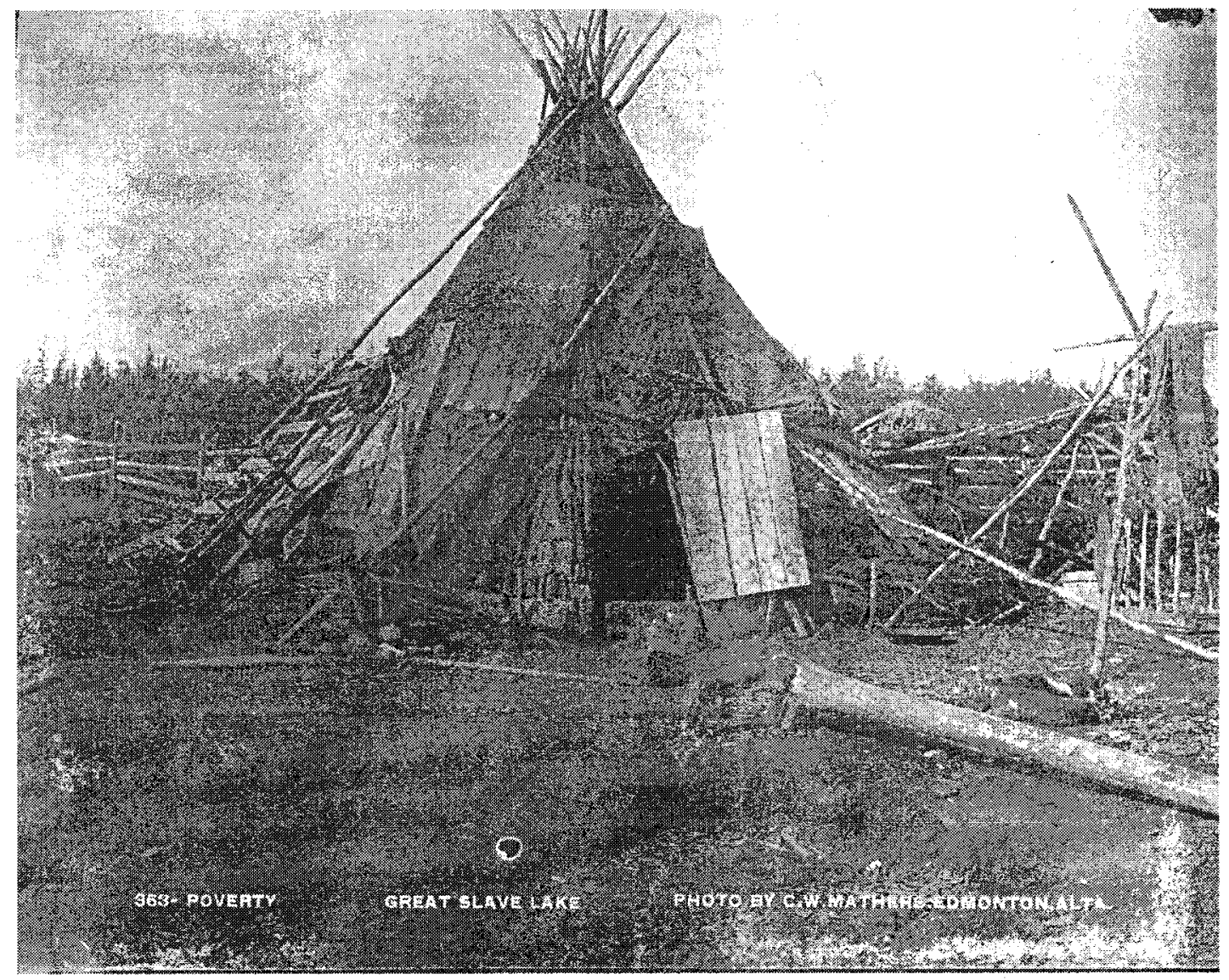

Plate 35: 363- Poverty Great Slave Lake

Source: B772 E. Brown Collection (PAA) PR1965.124 


\section{Codes and Curios}

Sumptuary and social codes featured prominently in Mathers' published account of his voyage; his textual and photographic renderings of them are important indicators of Euro-Canadian assumptions. For example, the difference between Inuit and Dene eating habits was seen as distinct and meaningful. In his account of the 1901 expedition, Mathers described in detail the Dene at mealtime, "as if the very existence of each depended on his getting there first. ... Dippers of beans, great chunks of bannock and bacon, and cups of tea strong enough to float a wedge ... I thought they would never get filled up." ${ }^{64}$ So insistent was Mathers in portraying the unmannered habits of the Dene that he included a long story of an encounter with two moose.

Just before the last two rapids [on the Athabasca] were 'run' I saw one of the finest sights of my whole trip. As we drifted around one of the many bends, two moose were sighted almost a mile away. Instantly everybody was alert. ... We were guided nearer to shore and still nearer to the unsuspecting moose. ... They are now both broadside to us facing each other about 100 yards away when crack goes the rifles. I expected to see the death struggle of one or both or else to see a fine exhibition of the moose speed, but ... I did not see either. They simply turned their heads and looked at us. That was the last touch of the magnificent picture. How my eyes drank in the sight. ${ }^{65}$

The account above comes from a description of the voyage Mathers wrote in 1901 but never published. The article he sent to The Farmer's Advocate remembers the scene quite differently.

... crack went the rifles. We would have drawn the curtain on the scene just there, but the events which followed impressed us so deeply we could not. Before the animals were half skinned, two of the Indians were eating a kidney apiece. The way the carcasses were cut up and mauled around was shocking. We saw an Indian trying to get a

\footnotetext{
${ }^{64}$ Mathers, "A Trip to the Arctic Circle," 7.

${ }^{65}$ Legislative Library Collection (PAA) 1974.1 file.425.1, C.W. Mathers, "untitled manuscript."
} 
considerable piece of the paunch into the hip-pocket of his blue overalls. $^{66}$

According to Mathers, "the Indian has a weakness for moose meat, and while any remains he feels it his duty to continue eating. ${ }^{67}$ In all likelihood, the second rendition is the falsified one meant to add authenticity and a sense of the exotic to the prairie audience reading about the trip, and increasing the value of the photographs detailing it.

The story stands in remarkable contrast to how Mathers was fascinated by the Inuit practice of "eating the raw tallow you find in the deer and eating raw meat by putting one end in their mouth and cutting off the bite by a murderous-looking knife held in the other hand. ${ }^{\prime 68}$ Mathers' interest led him not only to photograph this knife, but to acquire the piece as a curio which, along with a variety of other items, he brought back to Edmonton for display. It was not uncommon for stock photographers to house collections of curios in their studios, along with "engravings, pictures, and art goods of all descriptions ... manufactured by the native Indians," according to an advertisement placed by W.H. Boorne. On display, the actual work of the Inuit, explained to the Bulletin, exhibited their great skill and industriousness. The skill was exemplary of the ultimate in exoticism, a sought-after quality of value always defined in terms of its relevance to the everyday world of Edmonton. The Bulletin couched it in terms of human progress: "the knife is therefore worked by pushing from the operator, instead of drawing to him as is the case in the use of the draw knife or spoke shave which are used for like work by civilized peoples." 69

\footnotetext{
${ }^{66}$ Mathers, "A Trip to the Arctic Circle," 8.

${ }^{67}$ Mathers, "A Trip to the Arctic Circle," 8.

${ }^{68}$ Mathers, "A Trip to the Arctic Circle," 15.

${ }^{69}$ Edmonton Bulletin 16 September 1901: 2.
} 
The teleological power of images and objects in explaining pre-Columbian societies to colonisers was a culturally-entrenched practice by the mid nineteenth century. In reflecting on American art production, Brian Dippie suggests that the two main allegories in painting that summarized colonial ideas toward images and narratives are quite clearly, "works in which Indians were used to illustrate civilization's progress in America (celebratory); and those which focused on the Indians themselves as a vanishing race (commemorative)." ${ }^{70}$ Closer attention to this point is warranted. According to the Edmonton Bulletin, while photographs could represent 'better' than words, curios offered the most intimate experience of the North because "the actual work of the natives, bring them actually nearer than the photos." S11 Susan Stewart explains that these "traces of authentic experience" are invested by the souvenir's owner: "It represents not the lived experience of its maker but the "second-hand' experience of its possessor/owner." ${ }^{, 72}$ In dividing his experience of the North between the images he successfully rendered and the curios that he acquired for the people of Edmonton, Mathers was part of a widespread cultural transformation that encompassed the latter half of the nineteenth century. No longer could the two allegories of the disappearing Native and the backwards savage be reconciled in a single representational tactic. Curios, as part of their materiality, would be relegated to the gallery and display room, and for that reason 'commemorate' the disappearance of 'real' Natives from anywhere but anthropological museums, a protracted, localized process beginning in the present and extending into the past.

\footnotetext{
${ }^{70}$ Brian W. Dippie, "Photographic Allegories and Indian Destiny," in Images of the Indian: Portrayals of Native People, ed. Joe Sawchuk (Brandon: Bearpaw Publishing, 1995), 52.

${ }^{71}$ Edmonton Bulletin 16 September 1901: 2.

${ }^{72}$ Susan Stewart, On Longing: Narratives of the Miniature, the Gigantic, the Souvenir, the Collection (Baltimore: Johns Hopkins University Press, 1984), 135.
} 
Mathers, nonetheless, engaged with real men and women during his sojourn to the North. Steven Hoelscher notes how the viewer must always remember that, "although the photographer controlled the conditions surrounding photo making, this control was never absolute or unconditional.,"73 Thus, to a great extent Mathers' images transcribe important movements and events in First Nations historiography and understanding of contact, change, and colonialism. In her study of photography on the northwest coast of British Columbia, Carol Williams shares the view that colonial photography must be thought of as "active negotiation rather than a mechanical process" in order to account for a Native "pursuit of positive self representation [wherein] Native Americans revealed themselves as purposeful and strategic consumers," contrary to White assumptions that Native peoples were 'incompatible' with modernity and therefore a dying race. ${ }^{74}$ Williams cautions, however, that colonial uses of photography were beginning to coalesce in the later part of the nineteenth century as government, anthropological, tourist, and geological interests found common aspirations. ${ }^{75}$

Mathers' publication, $A$ Souvenir from the Far North, must be held accountable to this principle. Why, for example, did 'Eskimo in their Kayaks,' displaying two Inuit men facing the photographer directly and in semi-profile, remain unselected for inclusion into the booklet? [Plate 36] The image Mathers did use, 'Eskimos and their Kayaks,' has close similarities with what might be a more suitable alternative, but betrays the conventional logic that guided their production and circulation. Mathers did not see the men as Western subjects, but felt content to depict them as ethnographic others, turning

\footnotetext{
${ }^{73}$ Steven Hoelscher, "Viewing Indians: Native Encounters with Power, Tourism, and the Camera in the Wisconsin Dells, 1866-1907," American Indian Culture and Research Journal 27.4 (2003): 5.

${ }^{74}$ Williams, Framing the West, 139, 131.

${ }^{75}$ Williams, Framing the West, 50-84.
} 


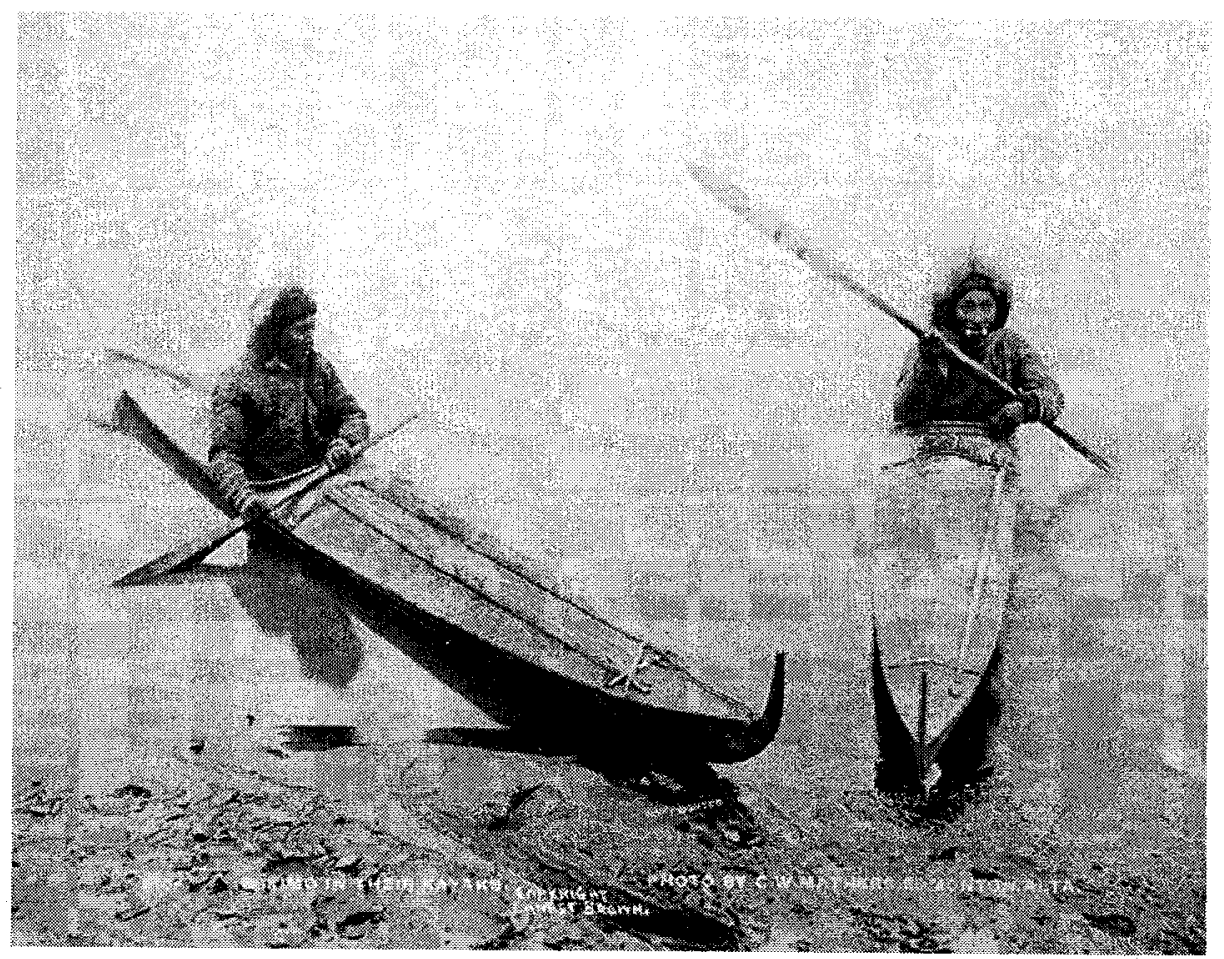

Plate 36: 310 - Eskimo in their Kayaks

Source: C-005106 Ernest Brown Collection (LAC) 1947-009 NPC 


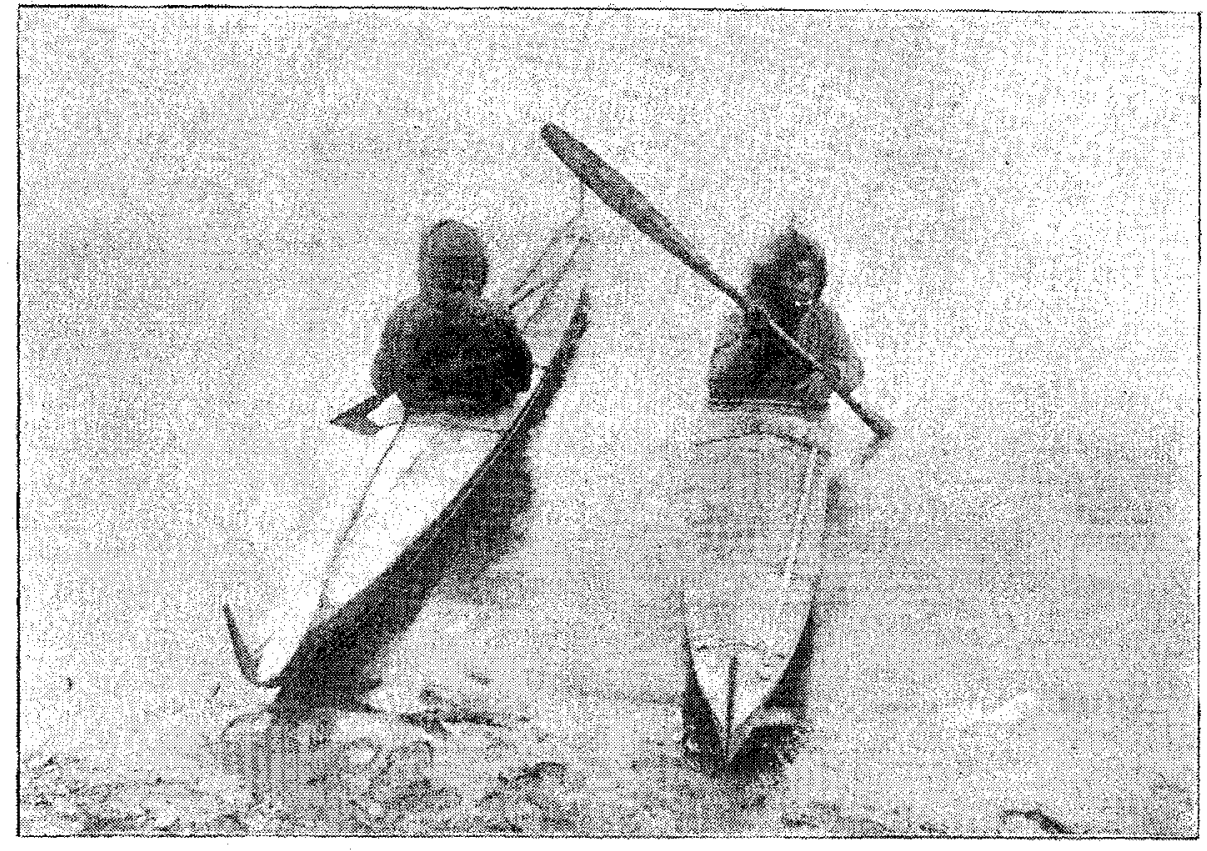

Es

\section{Plate 37: Eskimos and their Kayaks}

Source: C.W. Mathers, The Far North: A Souvenir From the North (Edmonton: C.W. Mathers, Minister of Agriculture, 1901), 20. 
one backward so as to open him to the gaze of scrutinization and display in a way that rejects any difference between the two men as outward appearances to which the first image may have alluded. The photograph simultaneously reduces individuality as it creates a static anthropological model of 'Esquimaux.' Here, the paddler is reduced to an Indian 'type' - another man turned backwards substitutes a perfect copy of the facing man. Western 'individualism' turned on the uniformity of the 'other.' [Plate 37] Indeed, to this effect, Mathers never depicted the Native and métis people of Denendeh and the Inuit in the same frame. His photographs tend to make more sense treated in this way, not as sites of contested meaning between photographer and photographed, but as discursive statements in a corpus of power-knowledge relations bound by a transparent artifice. Miles Orvelle adds that, "the authenticity of the camera, it was believed, was the authenticity of a machine that was accepted as a machine.,76

A large part of the meaning of Mathers' voyage derived from of the camera being in the North. Coates and Morrison make the analogy that, "The goal of newcomers was not to adapt to the North, but by the use of technological superiority or the expenditure of a great deal of money, to conquer the North and make it irrelevant to them." ${ }^{77}$ Though Mathers' return voyage through the sub-Arctic Denendeh must have been more difficult and longer than his entrance to the North, warranted by up-river travel at the height of summer, the narratives in his souvenir books end conspicuously at the height of the camera's power to represent the unrepresentable other - with the Inuit people on the Arctic Circle. The photographs Mathers had been making of the Native and métis inhabitants of the sub-Arctic, those people under 'civilized influences' who he did not see

\footnotetext{
${ }^{76}$ Miles Orvell, The Real Thing: Imitation and Authenticity in American Culture, $1880-1940$ (Chapel Hill and London: The University of North Carolina Press, 1989), 198.

${ }^{77}$ Coates and Morrison, "Winter and the Shaping of Northern History," 30.
} 
fit to pose in ethnographic fashion, would not be revisited. To do so would impugn the modernizing narrative his camera represented and unfolded.

\section{Meaning and Modernity}

Keith Walden reminds us that "as new technologies began to appear, as industrial capitalism reshaped structures and expectations of modern existence, the problem of meaning became more insistent. ${ }^{978}$ Change, and what it meant, was often up for grabs as accepted rules over space and time were contested and rewritten. Part of the great signifying power of photography rests in its capacity as a modernizing technology and as a maker of meanings, with one of these aspects always camouflaging or subsuming the other. The modernizing changes arriving in the North were, in photographs, presented to the Cartesian gaze of the viewer as the narrative of a smooth, reassuring progressive transformation into the future. This is because photographs established and narrated a 'past' anchored by the stability non-Aboriginals desired to see in the timeless and retrogressive world of the Inuit. The Athabasca-Mackenzie basin north of Edmonton, however, was anything but stable during the turn of the twentieth century. The 1890 s had been a period of rapid technological, social, and industrial change and 'advancement,' of which image-making was itself part and parcel. The Northern experience must be reconsidered, and a reconsideration of this kind requires identifying photography as a particularly modern discourse. We must, as Joan Schwartz strategizes, bring "context to the image, better to understand the context."79

Modernity, explains historical geographer Cole Harris,

\footnotetext{
${ }^{78}$ Keith Walden, Becoming Modern in Toronto: The Industrial Exhibition and the Shaping of a Late Victorian Culture (Toronto: University of Toronto Press, 1997), 6.

${ }^{79}$ Schwartz, "More Than 'Competent Description of an Intractably Empty Landscape': A Strategy for Critical Engagement with Historical Photographs," 107.
} 
may be thought of as a form of social organization characterized by a heightened capacity for the surveillance and management of individuals and populations, capitalist enterprise and industrial production, and the centralized control of the means of violence. As such, modernity was accompanied by the changing time-space relations associated with the technologies of transportation and communication that have evolved over the last two centuries. ${ }^{80}$

Harris suggests we must draw historical connections between characteristically modern forms of governance and control and the nascent forms of modern time-space devices and experience. In Mathers, a crisis immediately arises: how can early images depicting the North as distant, exotic, past, and unknowable be reconciled with the approaching 'modern' North of future progress, accelerated transportation, and compressed methods of staple movement and communication through space and time?

In part, the answer is provided by understanding Mathers' photographs both as a series of images that narrate a trader's river voyage north of Edmonton at the close of the nineteenth century, and as meaning-laden representations created and circulated in an age of mechanical reproduction that signal the opening of the twentieth century. Mathers' photographs allowed Edmontonians to visualize what could be their hinterland. Jeremy Foster points out that, "it is only when discursively used photographs draw (however indirectly) upon the lived dimensions of the experiential 'site' to which they refer, that they acquire the capacity to loosen old responses and create new subjectivities." ${ }^{81}$ This, more than anything, explains why the images of steamships can co-exist in The Far North, with images of Native and métis people tracking scows up the Athabasca.

\footnotetext{
${ }^{80}$ Harris, The Resettlement of British Columbia, xii.

${ }^{81}$ Jeremy Foster, "Capturing and Losing the 'Lie of the Land': Railway Photography and Colonial Nationalism in Early Twentieth-Century South Africa," in Picturing Place: Photography and the Geographical Imagination, ed. Joan M. Schwartz and James R. Ryan (London: I.B. Tauris, 2003 ), 144.
} 
Mathers made no images of bituminous limestone shale, virgin forests, or Devonian rock formations. All of his photographs, apart from the picturesque 'Midnight Sun' and 'Ramparts on the Mackenzie River,' have a distinct human presence in them. Unlike the photographs of Warburton Pike, Frank Russell, and Caspar Whitney however, his depictions of the North were not meant to remain insulated examples of a remote and exotic centre for masculine spiritual purification through encounters with the Dene and Inuit. Though his photographs drew upon those stories of northern representation in his encounter with the Inuit, Mathers had a much more nuanced appreciation for what he saw as the place of the Dene in industrial society. This distinction points to the most remarkable difference between Mathers' images and those of the explorers and adventurers who had travelled before him. Robert Bell and R.G. McConnell were unsuccessful in using photographs to capture the future of the North with their errant depictions of landscape. Pike, Russell, and Whitney made images that crafted a distinct impression of the North as a past place of rugged antimodernism. What makes Mathers' photographs particularly expressive of a new way of representing and communicating the North, I think, is that his images and souvenir books hinged these narratives together. Two of the most important meanings of the North that Mathers' camera re-narrated were found in the economics of space: trade and transportation.

\section{Steaming Towards the Future}

The increased use of steamboats on the Athabasca-Mackenzie system was indicative of what geographer David Harvey calls 'time-space compressions,' a shift characteristic of modernity which altered the way people interact with the objective dimensions of human experience. Harvey is interested in individual cultural practices 
and the way people represent, negotiate, and possess space. "[A] strong case can be made," he argues, "that the history of capitalism has been characterized by speed-up in the pace of life, while so overcoming spatial barriers that the world sometimes seems to collapse inwards upon us." ${ }^{82}$ Joan Schwartz has shown how in Canada, photography was implicated in changing and recording 'the speed of modern life' in a converse fashion, as capitalist innovation 'shrunk' space by improving the speed of transportation, photographic shutter speeds and chemical processes sped up in turn, allowing photographers to 'freeze' for the viewer objects moving at faster and faster speeds. ${ }^{83}$ In this case, Mathers' photographs not only depict the District of Athabasca at the close of the nineteenth century, they also mediate and suppress a chaotic and revolutionary surge in capitalist technologies, altering relationships of time and space in the North.

Both technologies of transportation and representation had an important symbolic role to modern societies. Steamboats are easily substituted into Jeremy Foster's analysis of railways in colonial South Africa, when he suggests that "because they both regulated and ordered time and space, railways and photography were also invaluable tools in the creation and definition of new political territories." ${ }^{84}$ The three steamers the HBC used to move goods and people up and down Athabasca-Mackenzie system were launched between 1882 and 1888 . Their construction was consistent with a range of general alterations in the method and means of transportation that included the ongoing improvement of the Athabasca trail from Edmonton to the Landing and the installation of a railway for pushcarts across an island in the Grand Rapids 100 miles north of

\footnotetext{
${ }^{82}$ David Harvey, The Condition of Postmodernity: An Enquiry into the Origins of Cultural Change (Cambridge, MA: Blackwell, 1990), 240.

${ }^{83}$ Schwartz, "Photography at the Speed of Life," 431-6.

${ }^{84}$ Foster, "Capturing and Losing the 'Lie of the Land'," 141.
} 
Athabasca. In The Far North, Mathers published two images depicting the steamer, Wrigley, named after the $\mathrm{HBC}$ factor. [Plates $38 \& 39]$

The symbolic value of the steamship to the North can be understood when contextualised within less-situated symbols of empire and modernity. Elihu Stewart, who travelled to the North shortly after Mathers, described the patriotic connotations of the steamboat to Euro-Canadians from the banks of the Athabasca at Fort McMurray on Dominion Day. With the steamboat in the lead, he remarked of the regatta that "every craft had some kind of a flag flying in honour of the day, which caused us to realise that though we were in a wilderness beyond the borders of civilisation, we were still in our own country and viewing our own possessions. ${ }^{, 85}$ Foster suggests that reactions like this explain how photography, as a technology of repetition, can work towards a normative kind of identity-formation in the conditions of modernity. He posits that "The ability of large groups to inhabit the same subjectivity towards a shared geographical space is dependent on imagery (visual or otherwise) which renders this imaginary space somehow comprehensible to all." 86 Mathers' choice to depict the Wrigley in the first instance, picking up a felled moose, suggests a Northern experience close to the one presented by Caspar Whitney and Warburton Pike. The second depiction, an impressive view of the great boat dominating the watercourse, prominently displays a massive Union Jack steadily waving from the stern of the craft. What is most interesting about the images, however, is not what they display, but what they do not. Considering imagemaking, John Wadland suggests that any act of 'framing' makes two statements: one about what is inside the picture and one about everything that is left out. Following this

\footnotetext{
${ }^{85}$ Elihu Stewart, Down the Mackenzie and up the Yukon in 1906 (Toronto: Bell and Cockburn, 1913), 54.

${ }^{86}$ Foster, "Capturing and Losing the 'Lie of the Land'," 143.
} 


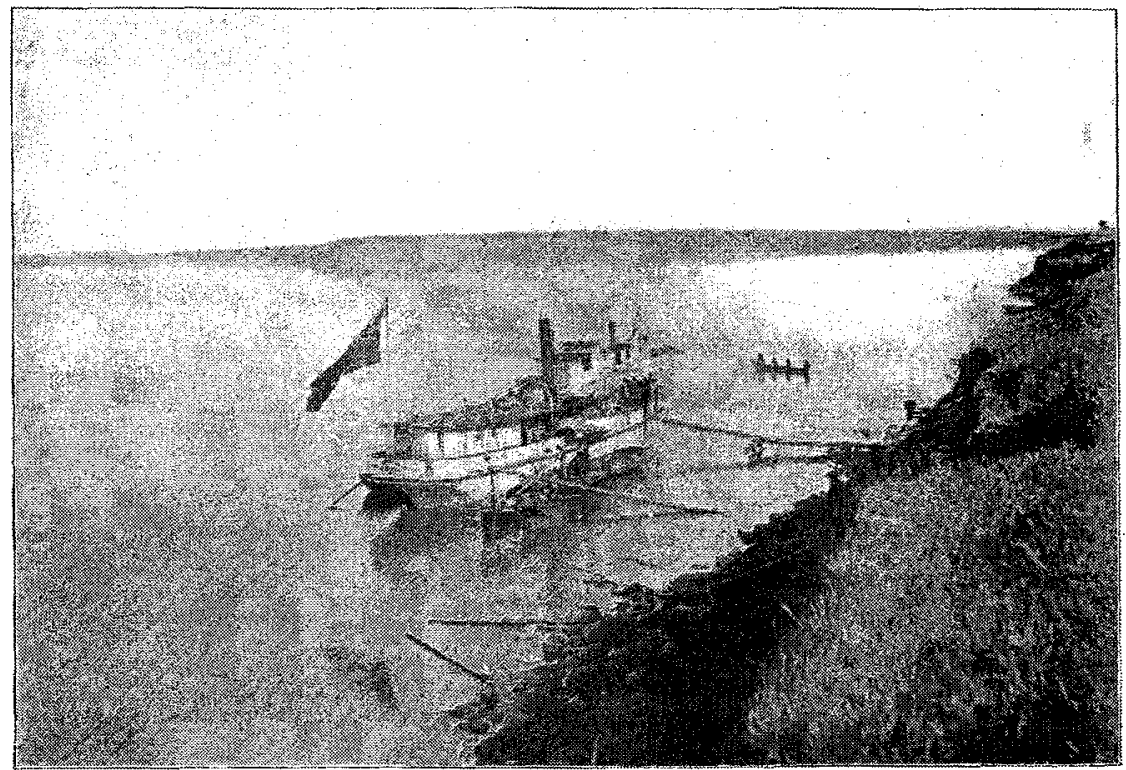

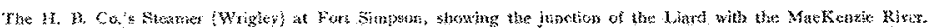

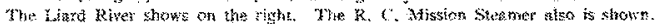

1.4

\section{Plate 38: The H.B. Co's Steamer (Wrigley) at Fort Simpson}

Source: Source: C.W. Mathers, The Far North: A Souvenir From the North (Edmonton: C.W. Mathers, Minister of Agriculture, 1901), 14. 


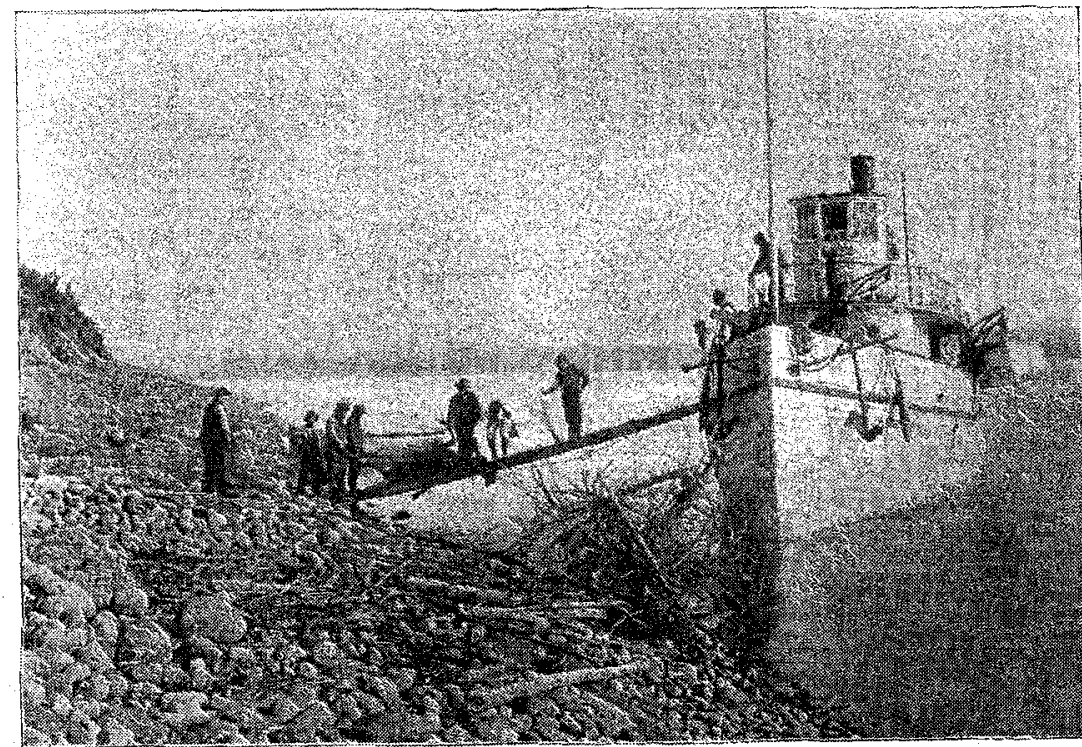

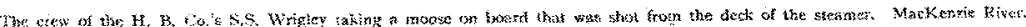

Plate 39: The Crew of the H.B.Co's S.S. Wrigley taking a moose on board. Source: Source: C.W. Mathers, The Far North: A Souvenir From the North (Edmonton: C.W. Mathers, Minister of Agriculture, 1901), 15. 
advice, the absence of the HBC forts or employees in relation to any of the steamer photographs must be taken into consideration. The ownership of the real technology by the HBC is muted in the images, and ownership of the symbol of the steamship becomes common domain. In a sense, the dislocation of the steamer Mathers portrays is functional in allowing it to drift out of its moorings and into the spaces of imagination, to become a disembodied symbol able to reify new versions of time and space into expressions of common political subjectivities.

\section{Challenging the HBC}

Mathers' souvenir book had a role in envisioning the dynamics of trade and capitalist economy in the North. After consolidating control of the Athabasca fur trade in 1821, the Hudson's Bay Company became the most enduring and powerful symbol of control in the region north of Edmonton. Although much has been written on the $\mathrm{HBC}$ as a barrier to Canadian expansionism, ${ }^{87}$ Arthur Ray notes that very little historical scholarship examines the HBC and its competitors after the sale of Rupert's Land in $1871 .^{88}$ During this time, one of the most important people in bringing modernizing change of competition to the North was Frank Oliver, editor of the Bulletin, free trader, and politician. Oliver's patronage, and that of other powerful capitalists in Edmonton, is evident in Mathers' photographic work. Oliver was Edmonton's most vocal agitator for the continued erosion of the HBC's powerful grip on the North.

From within its ranks, the HBC traders were already demoralized by the sale of the company to the International Financial Society in 1863, and the loss of their charter

\footnotetext{
${ }^{87}$ Owram, Promise of Eden, 168-216.

${ }^{88}$ Arthur J. Ray, The Canadian Fur Trade in the Industrial Age (Toronto: University of Toronto Press, 1990), xvi.
} 
six years later. ${ }^{89}$ In 1891, businessman C.C. Chipman took command of the company, and with him appeared newer, more capitalist, business practices. Employees who had undergone these changes hated the new ways, especially the loss of their 'officer' status and the transference from the deed poll to a waged salary system. ${ }^{90}$ Under pressure from Oliver, in 1893 the HBC began to allow free traders to operate on the northern river. This change brought the introduction of currency, displacing the made beaver exchange as the $\mathrm{HBC}$ also encouraged younger, more capitalistic traders to take over its river posts. The arrival of the new traders returned the District of Athabasca to the days of rivalry between the Hudson's Bay Company and the North-West Company, bringing competition, money and, inevitably, conflict.

Much of Mathers' derision towards the exchange system that characterized the North is evident in his rendition of a trading encounter between an $\mathrm{HBC}$ man and a fur trapper:

After the sorting and counting is done, the trader hands the Indian two pieces of paper. On one is marked the value of the fur and on the other the amount of his 'gratuity.' It seems a very absurd mode of trading. I give you so much for your furs and so much for nothing. The 'gratuity' is always traded out first. ... He and his wife, with the interpreter, are the only ones admitted into the store. The door is locked. They walk around and look at everything, pointing out what they want, and indicating the quantity by so many "skins." 91

Narratives indicating the antiquity inherent in the variety of exchange practised by the HBC and their Native or métis clientele were off-set by images of successful interaction between free traders. One of Mathers' most circulated images was that of a free trader who had been operating out of Fort Resolution since 1893, James Hislop, and an

\footnotetext{
${ }^{89}$ Zaslow, The Opening of the Canadian North, 53.

${ }^{90}$ Zaslow, The Opening of the Canadian North, 61.

91 Mathers, "A Trip to the Arctic Circle," 11.
} 
unidentified Inuit man. [Plate 40] Though the image is certainly staged, Raphael Samuel suggests that careful observation of constructed photographs can reveal more about their creators' intention, 'however fantasized,' than the work of the seemingly innocuous cameraperson. $^{92}$ The Edmonton trader and the Inuit barter on the porch of a cabin over a pipe. The luxury trade good is held aloft and centrepieced in the image, more interesting to contemporary Euro-Canadians than fur, as the implicit language of economics and exchange revolves and makes sense of the luxury good focusing the situation. ${ }^{93}$ Here we see that, regardless of the lack of any third voice of explanation or even a common linguistic background between the two men, trade supersedes language as an act of negotiation. 'Three dollars for the pipe?,' the trader's fingers seem to indicate. One can only guess at the implications of the gesture, but we are assured of the result that this Inuit man is all too pleased to part with the carving and participate in the trade.

The representations of Native and métis people in northern industry, like the line of freight packers at Grand Rapids shown in Mathers' souvenir book, require the consideration that the photographer may have intended to promote the usefulness of northern Natives in wage-economies of labour. [Plate 41] Orientalism, as conceptualized by Said, was at work here as well. 'Othered' peoples, believed to be capable of self-sufficiency only in an ancient past, were seen as "useful in the modern world only because the powerful and up-to-date empires have effectively brought them out of the wretchedness of their decline and turned them into rehabilitated residents of

\footnotetext{
${ }^{92}$ Raphael Samuel, Theatres of Memory: Past and Present in Contemporary Cultures (London and New York: Verso, 1994), 326.

${ }^{93}$ The pipe was more invested with non-Aboriginal ideas about the timeless traditions of the Inuit than any sense of its place in Inuit culture and history. Introduced to the Inuit as a companion to tobacco in exchange for fur during the eighteenth century, the pipe was nonetheless exempt from articles determined to be 'civilizing influences.'
} 


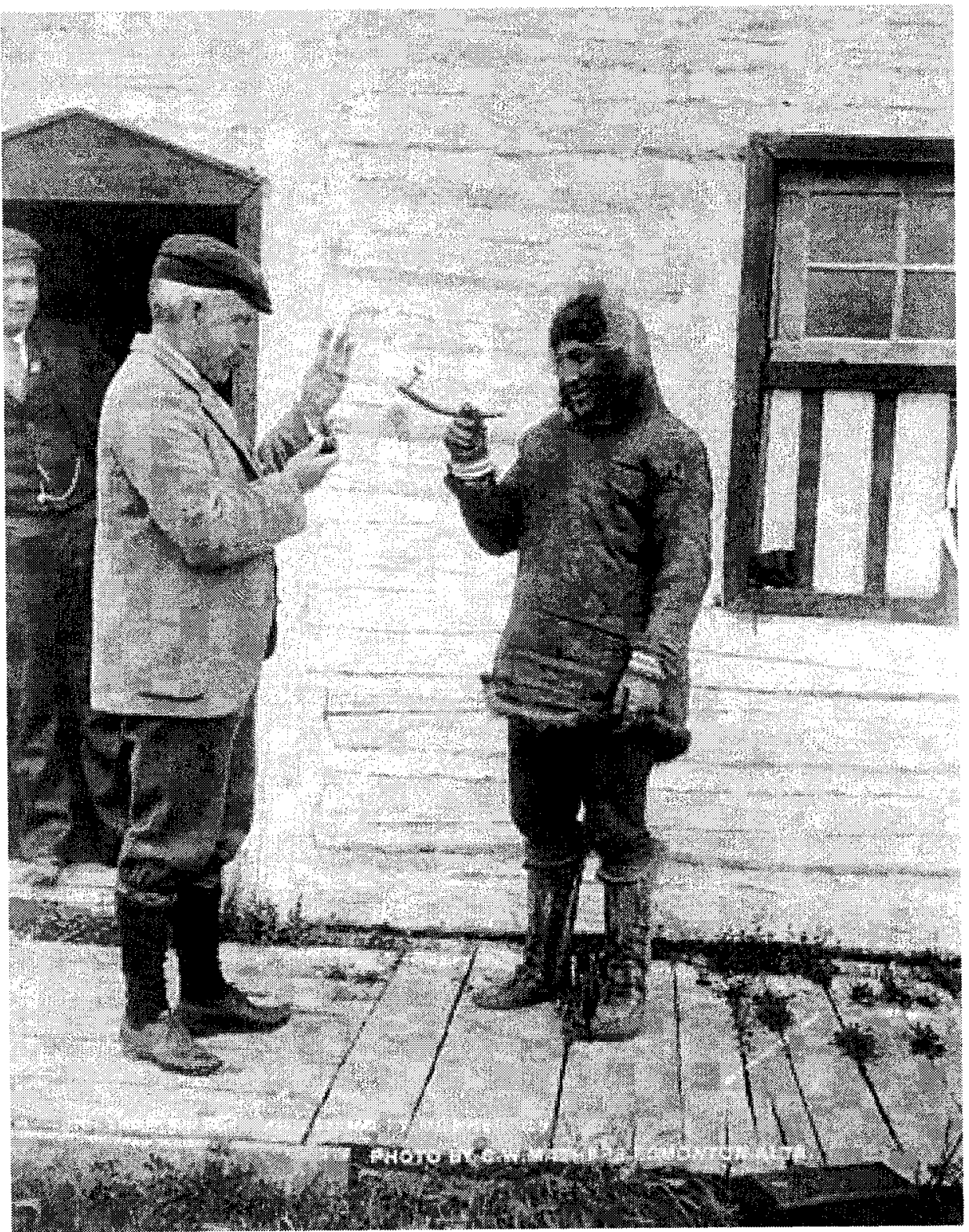

Plate 40: Trading with Eskimo, Ft. McPherson

Source: PA-124007 Minnesota Historical Society (LAC) 1963-092 NPC 


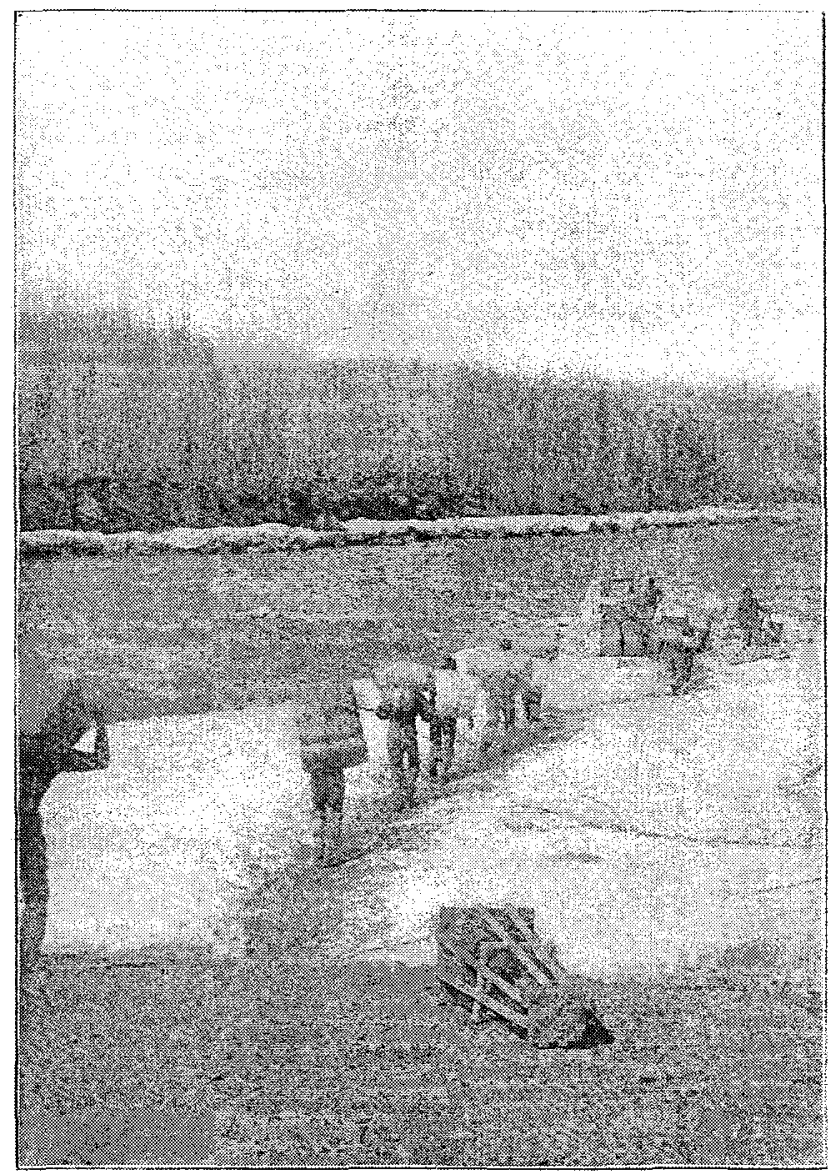

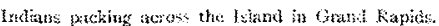

\section{Plate 41: Indians Packing across the Island in Grand Rapids}

Source: C.W. Mathers, The Far North: A Souvenir From the North (Edmonton: C.W. Mathers, Minister of Agriculture, 1901), 5. 
productive colonies." 94 Adele Perry has described the enactment of such strategies as efforts to "reformulate First Nations men as economic subjects," as producers and consumers in industrial economies. ${ }^{95}$ Efforts only increased after the Oliver's successful campaign for free trade in 1893. As Oliver and other capitalists in Edmonton and the North-West Territories moved northward, the HBC countered by attempting to close the northern routes to outsiders. The Chicago Daily Tribune informed its readers on August $19^{\text {th }}, 1897$, that the passage through Edmonton to the gold fields, "has been in use for nearly a century. Along it are located a dozen great trading posts where the Hudson Bay company exchanged civilized products for gold and furs of the Indians," 96 but the HBC had other plans. Eleven days later the paper reported during the beginning of the Klondike gold rush that the $\mathrm{HBC}$ had shut down Fort McPherson and seven other key posts along the Athabasca-Mackenzie system to outsiders. From Winnipeg, HBC man E.B. Nixon informed American audiences that "semi-starvation, if not worse, and cold await the prospectors who make a late start via the Edmonton route." 97 Despite such deterrence, the Klondikers came, and brought with them money and further economic shifts. Against the designs of the HBC, Mathers and Frank Oliver would capitalize on the newcomers in their selling of a route to the North exclusively through Edmonton. They had collaborated in 1897 in an article written by the latter for The Nor'west Farmer entitled "To the Klondike - The All Canadian Route." A biased piece encouraging gold seekers to opt for passage through Edmonton as opposed to the Chilkoot Pass, the text

\footnotetext{
${ }^{94}$ Said, Orientalism, 35

${ }^{95}$ Perry, "From 'the Hot-Bed of Vice'," 596.

96 "New Route to the Klondike," Chicago Daily Tribune 19 August 1897: 5.

97 "Shuts Door to Gold," Chicago Daily Tribune 30 August 1897: 2.
} 
was illustrated with four of Mathers photographs from a trip to Athabasca Landing the same year. $^{98}$

\section{Conclusion - C.W. Mathers' Northern Vision}

The irony of Mathers' and Oliver's 'All Canadian' invitation to the Klondike of

1897 was that Oliver had spent the previous year warning readers of the Edmonton

Bulletin that the North was fast becoming destabilized. ${ }^{99}$ Oliver's goal was a Treaty with the northern Natives that would pacify the district and render it firmly subject to

Edmonton's and Ottawa's control. Oliver, as Member of Parliament for Edmonton, believed that northern development should be unconditionally supported by the Dominion and Territorial governments, and "became vitriolic when anyone disagreed."100 At his urging, an RNWMP detail was despatched to the basin in the winter of $1897 .{ }^{101}$ In November of the next year, the results of the Klondike rush were enough to justify federal involvement in the North. The long anticipated Treaty No. 8 was finally approved to be 'set-up' by an Order-in-Council. The language of the order unequivocally detailed the logic of modernity and the paternalism of the state, claiming that the "country to be treated for should be thrown open to development and the lives and property of those who may enter therein safeguarded by the making of provision which

\footnotetext{
${ }^{98}$ Frank Oliver, "To the Klondike - the All-Canadian Route," The Nor'-West Farmer 16.22 (1897): Silversides, "Charles Wesley Mathers," 453-59.

${ }^{99}$ Donald G. Wetherell and Irene Kmet, Alberta's North: A History, 1890 to 1950 (Edmonton, Alta.: Canadian Circumpolar Institute Press, University of Alberta Press, Alberta Community Development, 2000), 47.

${ }^{100}$ Wetherell and Kmet, Alberta's North, 83.

${ }^{103}$ The recorded intention of the patrol was "to obtain an exhaustive report on the condition of affairs there generally, and particularly to collect information likely to be useful to the government in their future dealings with that territory." The report of the officer in charge, A.M. Jarvis, characterized the northern mood towards the new use of arsenic in fur trapping: "Indians complained bitterly of the use of this poison put out by white men and half-breed trappers with whom they are unable to compete, and think it hard that people who are not owners of the country are allowed to rob them of their living." Government of Canada, North-West Mounted Police Patrol. Athabaska District, Winter 1896-97, prepared by A.M. Jarvis (Ottawa: Government Printing Bureau, 1897), 1-17.
} 
will remove all hostile feeling from the minds of the Indians and lead them to peacefully acquiesce in the changing conditions." 102

With this new 'context brought to the image,' Mathers' photographs of northern Natives and métis involved in the industrial economy of the North assume an awesome new importance. Charles Mair, who accompanied the 1899 Treaty Expedition to the North, believed that the northern Native and métis people required the document "to protect them from a new aggressor with whom their rude tribunals were incompetent to deal." 103 Mathers' images of 1901 seemed to be saying that Treaty 8 had been successful in turning Pike and Whitney's 'uncivilized' Natives into economic participants at work in the modern North, but that the romantic and savage 'other' was still present in the Inuit. The instability and change of the 1890 s was wound into stable narratives about the meaning of the North and the position of the 'other.' The new North, Mathers' souvenir book proclaimed, was 'open' to new economies of capitalism and investment; the dominant way of envisioning the Northwest had moved, in the words of Margery Hadley, "from one of landscape-as-barrier to one of landscape-as-commodity."104 Furthermore, the Athabasca region, at least, was no longer an Aboriginal place, the latter having moved to the Arctic. Cole Harris explains that non-Aboriginal settlers arrived in North America convinced land must be both purchased and used in order to be owned: "derived primarily from Britain and from the long struggle, which was essentially over by the mid nineteenth century, to detach ownership of land from use rights to it and, thereby, make it

\footnotetext{
${ }^{102}$ Government of Canada, Order in Council for Commission Setting up Treaty 8. P.C. No. 2749, prepared by R.W. Scott (1898), n.p.

${ }^{103}$ Mair, Through the Mackenzie Basin, 7.

${ }^{104}$ Margery Tanner Hadley, "Photography, Tourism and the C.P.R.: Western Canada, 1884-1914," in Essays on the Historical Geography of the Canadian West: Regional Perspectives on the Settlement Process, ed. L.A. Rosenvall and S.M. Evans (Calgary: Department of Geography, University of Calgary, 1987), 68 .
} 
more accessible and responsive to the market." ${ }^{105}$ When the context and artifice behind C.W. Mathers' A Souvenir from the North is considered, however, it is clear that historians and geographers must pay close attention to the role photography played in the expropriation and representation of the land itself.

${ }^{105}$ R. Cole Harris, Making Native Space: Colonialism, Resistance, and Reserves in British Columbia (Vancouver, B.C.: University of British Columbia Press, 2002), 266. 


\section{Chapter 5: Recirculation to 1914}

\section{Introduction - MacFarlane's Paper, Mathers' Photographs}

In 1905 Roderick MacFarlane received a letter from the famed author and naturalist Ernest Thompson Seton urging him to take up the pen and write down the story of his adventures in the North, citing the example of James Macdonald Oxley and his popular story, Archie of Athabasca. As an author and literary personality himself, Seton argued the wisdom of his opinion to his friend:

To begin with there is at present a lively interest in all American works of travel and adventure, but especially in those that relate to the far north, because this is today the least known part of our country. If $\mathrm{Mr}$. Macdonald can put down on paper a vivid account of the wild men, wild animals, and wild scenes he has lived with, telling it just as he would to interest a room full of intelligent men, he would certainly make a book that would have a wide sale. It would be an enormous help to the book with the publisher as well as with the public if he could furnish illustrations, drawings or photographs and occasional maps. The more interesting pictures, the better. ${ }^{1}$

Roderick MacFarlane's first year in the service of the Hudson's Bay Company was spent at Fort Good Hope on the Mackenzie River, halfway between Great Slave Lake and the Arctic Ocean. The year was 1853 and, like many 'HBC men' of that time, MacFarlane had been hired in his native Scotland at age sixteen to head for the Northwest. His time in the Districts of Athabasca and Mackenzie was spent exchanging fur at a number of different posts up and down the Athabasca-Mackenzie route, before being promoted to Chief Trader in 1868 . Like many European recruits to the HBC, MacFarlane also brought his interest in science and exploration to the North. His sympathetic attitude towards natural history endeavours made him a valuable affiliate to

\footnotetext{
${ }^{1}$ Roderick MacFarlane Fonds (LAC) MG29 A11 file.1998, "Correspondence," Emest Thompson Seton to Roderick MacFarlane, 1905.
} 
those explorers and scientists wise enough to ask him for a 'letter of introduction.'

MacFarlane's letter would have been presented to the officer in charge of the many fur posts of the North in return for lodging and dinner in the officer's house. Frank Russell recalled meeting MacFarlane in 1891, and identified him as an inspiration because his, "extensive and very valuable collections of natural history specimens. His enthusiastic descriptions of the field, as yet almost unexplored, roused in me a strong desire to visit the Far North."2 MacFarlane's specific interest in ornithology had added greatly to the Library and Natural History Museum that Captain Bell had arranged in an unused warehouse in Fort Simpson, the largest HBC post on the Mackenzie River. Frank Russell described the museum in the early 1890 s as, "a creditable showing of the fauna of that region" and wished it had better quarters. ${ }^{3}$

The museum would have been of great interest to the scores of geologists, biologists, ethnographers, and surveyors travelling up and down the river system, who were always happy to converse in science and politics with the post officers of the HBC. In the introduction to Barren Ground, Warburton Pike explained how difficult it was to convince some people that he travelled to the region on his own accord, not funded and on behalf of some government-scientific body. In numbers that reflect the improving transportation systems, a great machinery of collecting, itemizing, knowing, and displaying the world began to grind its cogs as G.M. Dawson's "Map of the Larger Unexplored Regions" gradually extended into the North. As early as 1842 the British Museum had been requesting specimens and papers on the Mackenzie, and Robert Bell's museum in Ottawa had been taking samples since the $1880 \mathrm{~s}$, but a whole new interest in

\footnotetext{
${ }^{2}$ Russell, Explorations, iii.

${ }^{3}$ Russell, Explorations, 132.
} 
the Athabasca-Mackenzie was developing in the 1890s. Likely in response to the popularity of Russell's Explorations in the Far North and a successful expedition by Alfred Preble on behalf of the U.S. Biological Survey, the Smithsonian Institution in Washington was beginning to collect papers and samples relating to northern Canada.

Probably one of the most important documents in their possession was Roderick MacFarlane's "Notes on Mammals, with Remarks on Explorers and Explorations of the Far North" published in the museum's annual proceedings of 1892. That an HBC officer with little formal training was solicited to draft scientific papers and be published by one of the world's premier scientific institutions expressed what Suzanne Zeller has identified as the 'incremental spirit' common to science in utilitarian societies. The purpose, she writes, "was to increase and diffuse knowledge. Any individual could add piecemeal to the stock of knowledge and was encouraged to do so."4 The implicit connections between a system of government and an epistemology of scientific research should not be missed. As Zeller explains, utilitarianism in scientific practice derived from a need to combat chronic social problems that developed in Britain during the industrial revolution. The doctrine held that the accumulation and ordering of facts could make social bodies manageable. In pre-confederation Canada, Zeller argues that the idea of a transcontinental nation was made possible particularly in the sciences of geology, botany, and meteorology. Before the concept of Canadian 'culture,' Zeller argues, science "refocused Canadians' vision of the land they inhabited, broadening their conceptual horizons and encouraging them to carve out a place for their developing society."

\footnotetext{
${ }^{4}$ Zeller, Inventing Canada, 4.

${ }^{5}$ Zeller, Inventing Canada, 6.
} 
It was therefore not without a sense of his own heroism that Charles Mair could tell the readers of his 1908, Through the Mackenzie Basin, that "Notes on Mammals" and another of MacFarlane's papers, "Notes on and List of Birds and Eggs Collected in Arctic America," would be republished in his own book. Mair explained that "It seemed to the writer very desirable that this information, hidden away in the 'Proceedings' of a foreign scientific institution, would be given to the Canadian public." Mair theorized that it was a "profit to his readers, to connect it with his own narrative of the Treaty Expedition of 1899."

For his part, MacFarlane generally echoed Mair's enthusiasm, adding that the example of HBC officers should inspire others to make "similar exertions on similar lines, and thus contribut[e] to the Natural History of their Great Dominion." MacFarlane went a step further, drawing a connection between the quantity of scientific classification accomplished and the validity of Canada as a country, invoking the

National Museum as the house of the Canadian spirit in a pantheon of nations.

The National Museum at the Capital is without doubt a credit to the authorities, but if the people wish to own such an institution as they might and ought to have, then every effort should be put forth in order to secure, first, the filling up of the many gaps in the catalogues of wellknown species, which the result of future explorations duly communicated to the scientific world. ${ }^{8}$

The repatriation of what was seen as an important part of Canada's natural-national history brought with it more than an addition to the 'catalogue' of knowledge about the country. MacFarlane's contribution had been significant enough to warrant republication

\footnotetext{
${ }^{6}$ Mair, Through the Mackenzie Basin, 8.

${ }^{7}$ Roderick MacFarlane, "Notes on the Mammals and Birds of Northern Canada," in Through the Mackenzie Basin: A Narrative of the Athabasca and Peace River Treaty Expedition (Toronto: William Briggs, 1908), 151.

${ }^{8}$ MacFarlane, "Notes on the Mammals and Birds of Northern Canada," 151.
} 
as an occasional paper of the Smithsonian in 1905. The second printing, unlike the first, contained four photographs taken by Charles Mathers in 1901, including 'The Ramparts, Mackenzie River,' 'Fort McPherson on Peel River,' 'Fort Chipewyan,' and 'Fort Resolution on Great Slave Lake."9

Although it is unclear whether MacFarlane or someone else furnished the Smithsonian with Mathers' photographs of these northern locations, their status in relation to the text is ambiguous and yet unwavering. MacFarlane's scientific rendering of the mammals inhabiting the Mackenzie River District consisted of an eclectic blend of the scientific record, trader's tales, Native correspondence, natural history, popular novels, ship's logs, fur trade accounts, personal anecdotes, and sport hunting in order to catalogue the species of the region. Knowledge was indeed egalitarian; MacFarlane could state that the Indians assured him that a "female [Woodland Buffalo] rarely has more than one calf at a birth," a fact given with equal regard to Dr. Armstrong's seventeen-year study of the migratory patterns of Barren Ground Reindeer. ${ }^{10}$ Considered against these stories in this instance, Mathers' images appear simply as another form of information about a general thing.

\section{Recirculation}

As a practice of empire during the late nineteenth and early twentieth centuries, photography "incorporated a role as "handmaid of the sciences." "11 To acknowledge photography as a tool of scientific recording hides another world, however. James Ryan reminds us that, ultimately, photographs' power in picturing place by translating

\footnotetext{
${ }^{9}$ Roderick MacFarlane, Notes on Mammals Collected and Observed in the Northern Mackenzie River District, Northwest Territories of Canada, with Remarks on Explorers and Explorations of the Far North (Washington: Government Printing Office, 1905).

${ }^{10}$ MacFarlane, "Notes on the Mammals and Birds of Northern Canada," 178, 164.

${ }^{11}$ Ryan, Picturing Empire, 72.
} 
"unknown spaces into familiar scenes ... [depended] upon their circulation and reception across a range of spaces." ${ }^{12}$ Studying photographs through reproduction, however, proves a daunting task, since the Archimedean maker of meaning - the author or cameraperson - recedes from control over the image as, with each reproduction, it is embedded and remarks upon a new text, new medium, and new author. Elizabeth Edwards suggests that we abandon the search for authorship and explore specific photographic experiences. By this she means, "how photographs and their making actually operated in the fluid spaces of ideological and cultural meaning.,"13

Mathers' pictures spoke to a disparate, broad cultural spectrum, what Mary Louise Pratt has called "the vast, discontinuous, and overdetermined history of imperial meaning-making." 14 In some instances, as we have already seen with MacFarlane, his photographs appeared in scientific and geological publications. In other cases his images buttressed and predicted the voyages of a new traveller to the North: the tourist. Tourists arrived in the Athabasca-Mackenzie basin with specific expectations, probably drawn in part by Mathers' souvenir books in what Joy Kasson calls "anticipatory nostalgia."15 Though federal employee Elihu Stewart and freelance journalist Agnes Deans Cameron had different reasons for being in the North, both of their voyages indicated that the regime of spectatorship that opened the twentieth century was not entirely separate from the antimodern posturing of earlier travellers. Travelling north still meant stepping into the past where, contrary to some of their original meanings, Mathers' images were put to

\footnotetext{
${ }^{12}$ Ryan, Picturing Empire, 72.

${ }^{13}$ Elizabeth Edwards, Raw Histories: Photographs, Anthropology and Museums (Oxford and New York: Berg, 2001), 3.

${ }^{14}$ Mary Louise Pratt, Imperial Eyes: Travel Writing and Transculturation (London and New York: Routledge, 1992), 4.

${ }^{15}$ Joy Kasson, "Staking a Claim to History," in The Nineteenth Century Visual Culture Reader, ed. Vanessa R. Schwartz and Jeannene M. Przyblyski (London and New York: Routledge, 2005), 283.
} 
use depicting a place devoid of the trappings of modern life. Travellers used photographs to perceive the anachronistic space where entrenched racial essentialisms could be reaffirmed. Canadian historians, as Agnes Laut's work conveys, were deeply involved in this historical imagining of a geographical past. Following the specific movement of Mathers' images through these different discourses and disciplines can help us explain how images in recirculation caused the 'fluid spaces of ideological and cultural meaning' to congeal around a powerful new meaning of what Zaslow called the 'opening' of the Canadian North.

\section{Representations and Knowledges}

Mathers' images of northern fur posts, far from being odd inclusions in a scientific paper, probably expressed what MacFarlane, and the Smithsonian at least, felt was valid scientific evidence. In this sense, one of the most important spaces of cultural meaning enabled by the recirculation of Mathers' photographs was an understanding of North unified by science and history. The story of acquiring the knowledge of the North was as, or more, important than the 'knowledge' itself, and the remote posts deep in the 'uncivilized' North expressed more than anything the romantic image of the scientistadventurer made so popular by Richardson, Back, and Rae. Sir Alexander Mackenzie, after all, had been stationed at Fort Chipewyan when he 'discovered' the Peace and Mackenzie Rivers. Filling out the 'catalogue' of Northern experience was by no means a new idea. Robert Bell expressed these ideas spatially in his 60-year map made especially for the annual Report of Progress, and later converted into the lantern slide, "Shewing Progress of Field Operations.' [Plate 42] 


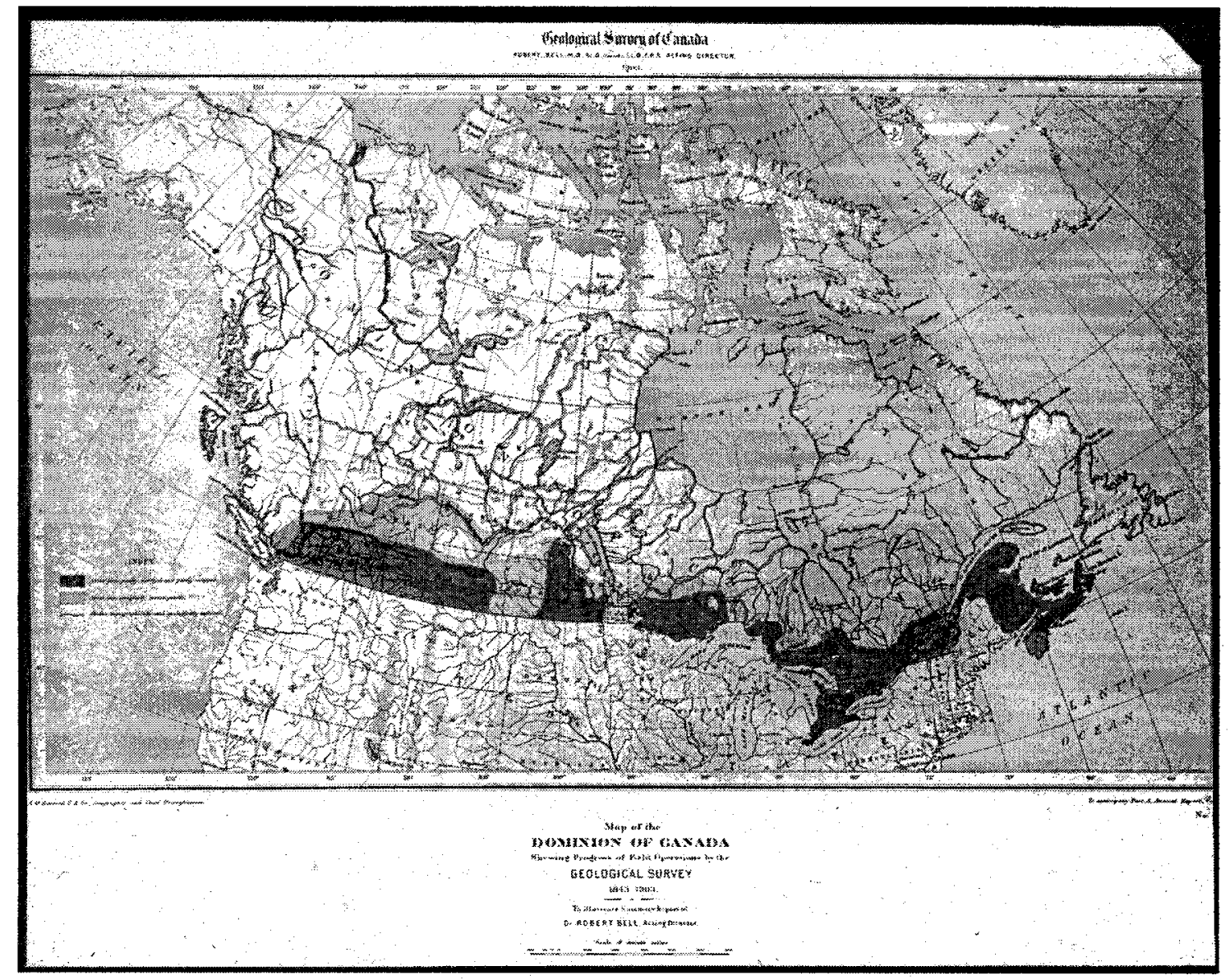

Plate 42: Shewing Progress of Field Operations by Geological Survey, 1843-1903 Source: e006580817 Robert Bell Collection (LAC) 1984-318 NPC 


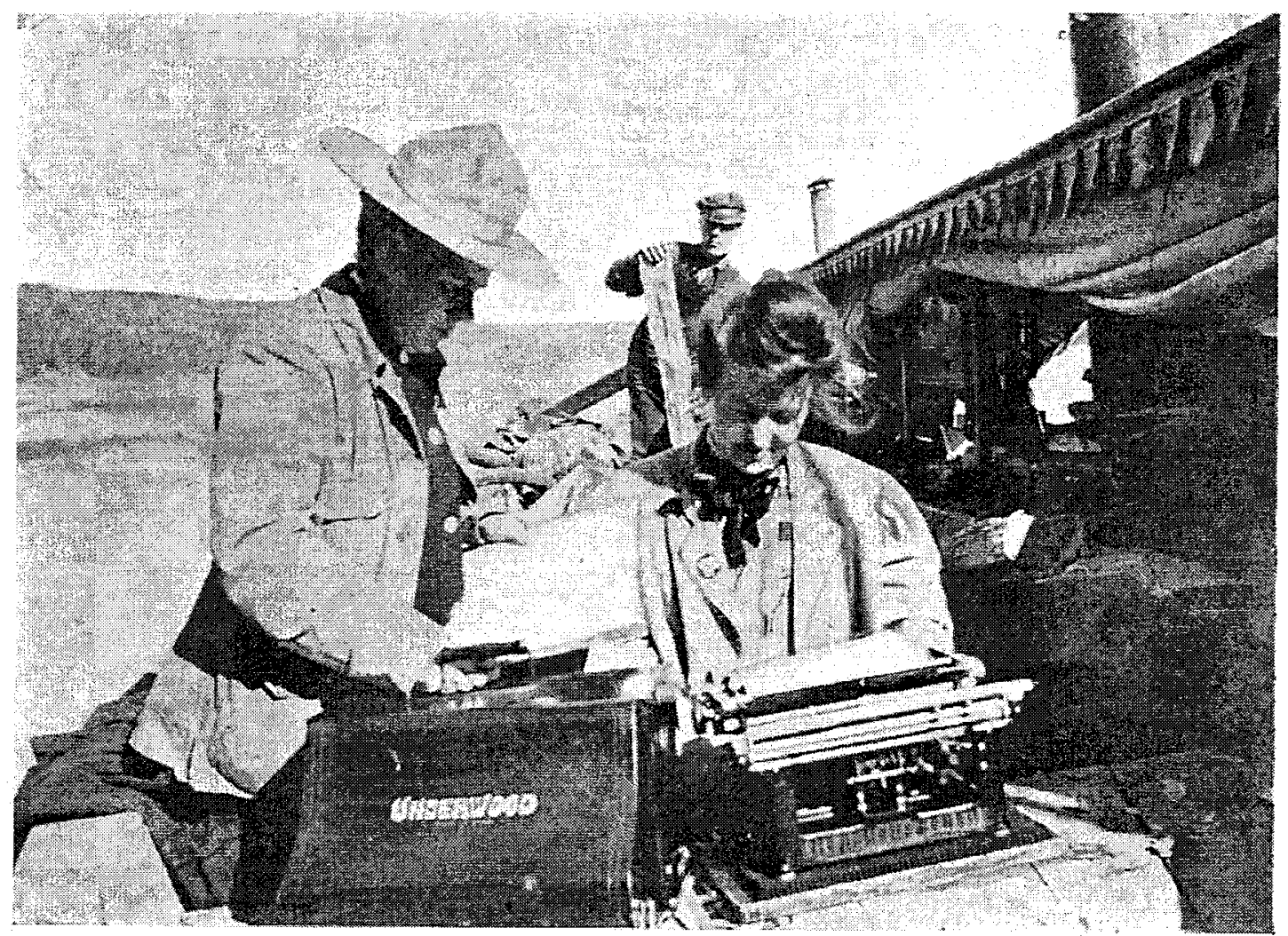

We Tell the Tale of a Whale

\section{Plate 43: We Tell the Tale of a Whale}

Source: Agnes Deans Cameron, The New North: Being Some Account of a Woman's Journey through Canada to the Arctic (New York \& London: D. Appleton and Company, 1910), 282. 
Derek Gregory argues that "mapping is necessarily situated, embodied, partial: like all other practices of representation." noting the representational refraction involved in the production of this lantern slide. Bell initially created the map to represent the actual material land; the map was then photographed to allow a number of photo-mechanical reproductions to be made of the original representation of the landscape. The photo-reproduction was eventually made into a lantern slide in order to project the image onto a screen and therefore multiply the number of people who could simultaneously look at a reproduction of a copy of a representation meant to accompany Bell's many public speaking engagements and university lectures on the resource potential of the land and the progress of the GSC in rendering the land known and useable to Canada. The impressive machine of reproduction generating these labyrinthine layers of origin all reflected the growing faith placed in science and technology to accurately render and display material reality. Often the process of improving the accuracy of reality's mirror was intentionally presented, as displayed in photographs from the travelogue of northern voyager Agnes Deans Cameron. An image from 1908 records Cameron and her niece at work recording the North. Another image of the same machine, 'The First Typewriter on Great Slave Lake,' testifies to the importance placed in bringing new technologies to the North - the modern typewriter was only refined in 1895 - and the great success its safe and dry arrival meant. [Plate 43] It is against these refractions that W.J.T. Mitchell reminds us that when we

\footnotetext{
${ }^{16}$ In this passage, Gregory is reflecting upon the work of Brian Harley. Derek Gregory, Geographical Imaginations (Cambridge, MA: Blackwell, 1994), 7.
} 
look at an image, what we see is "a representation of something that is already a representation in its own right." ${ }^{17}$

The growing body of knowledge about the North multiplied with each new exploration making reference to an old exploration. In 1903, the same year as his impressive map was created, Bell, acting director of the GSC, wrote Mathers at his studio in Edmonton to order a number of 10"x7" prints, among them 'Fort McPherson,' 'The Ramparts,' and 'Tracking on the Athabasca.' He also asked for pictures of places such as Lac La Biche, Fort Vermillion, Fort Dunvegan, Fort Pitt, and Fort Victoria, suggesting that by 1903 Mathers was catering to a broader geographical representation. ${ }^{18}$ Some notes Bell made on his order indicate his intention to use the pictures to exemplify the great potential for farming in the Mackenzie basin.

MacFarlane, alternatively, made no pause even to consider farming in the North. His Mackenzie was the rugged contest of man against nature, the titanic majesty of the Ramparts and the Mackenzie River versus the obstinate settlements of European populations. This view, in part, was derived from MacFarlane's own work in the North. When Agnes Deans Cameron visited into the Fort Simpson museum in 1908, she came "across the mouldy remains of a once splendid museum of natural history," with rotten specimens, "now dropping their glass eyes and exposing their cotton-batting vitals to the careless on-looker." ${ }^{\prime 19}$ MacFarlane would have been aghast at her judgement of the dilapidated Simpson post: "everything is so old in this North that there is no veneration

\footnotetext{
${ }^{17}$ W.J.T. Mitchell, "Imperial Landscape," in Landscape and Power, ed. W.J.T. Mitchell (Chicago and London: The University of Chicago Press, 1994), 14.

${ }_{18}$ Robert Bell Fonds (LAC) MG29 B15 vol.44 file.12, "Photography-Memorabilia."

${ }^{19}$ Agnes Deans Cameron, The New North: Being Some Account of a Woman's Journey through Canada to the Arctic. With Many Illustrations from Photographs by the Author. (New York and London: D. Appleton and Company, 1910), 179.
} 
for old things." ${ }^{20}$ Contrary to Cameron's remarks, MacFarlane's time as chief HBC factor of the North was spent in efforts to venerate the past. When transferred in 1870 , instead of just moving to Fort Chipewyan, MacFarlane rebuilt the post in the fashion of the old Company. Katherine Hughes, who also toured the area in 1908 and wrote MacFarlane with questions about a book, found she was unable to "close my letter without congratulating you and doing so with a thankful heart for the way you built up the Chippewyan of today. I found the place fascinating - the only place in the North that retains the old-time atmosphere - and that is mainly due to the way in which you rebuilt the Fort."21 While Peter Geller has identified the dawning of a historically conscious $\mathrm{HBC}$ with the efforts of the new corporate business using photographs to write the company as a peaceful civilizer of Natives into the story of Canada during the $1920 \mathrm{~s}$, here were European officers recreating the built environment of history in the far northern reaches of their trading grounds. ${ }^{22}$

The significance of recirculating photographs is not their ability to represent history, science, or agriculture, but the ability to hold and manifest text and narratives despite the conflicting or cohesive intentions of their users. As the original images Mathers produced of his voyage to the Far North indicate, the possibilities of representation and narration shift as different powers and technologies act upon the photographs. The first images displayed in Mathers' storefront (Chapter 4) - those without many copies - that accompanied the curio collection of Native and Inuit crafts

\footnotetext{
${ }^{20}$ Cameron, The New North, 180.

${ }^{21}$ Roderick MacFarlane Fonds (LAC) MG29 A11 file.2168-2169, "Correspondence," Katherine Hughes to Roderick MacFarlane, 1909.

${ }^{22}$ Peter G. Geller, "'Hudson's Bay Company Indians': Images of Native People and the Red River Pageant, 1920," in Dressing in Feathers: The Construction of the Indian in American Popular Culture, ed. S.

Elizabeth Bird (Boulder: Westview Press, 1996), 65-77.
} 
acted as powerful evidence in fixing and reflecting the nuanced world at the 'edges of empire' where colonizers and colonized sought to explain the presence and practice of the other. The initial images were personal, bound through referential strategies to the objects they represented and explained. The images were produced in Edmonton, by an Edmontonian, to show what and who lay beyond their gates. Once published in a souvenir album that was sold locally however, broader meanings about the North could be addressed. On the hopeful eve of provincial status seen in the Laurier government, the souvenir book of the North by Mathers conspicuously attempted to erase the power of the $\mathrm{HBC}$ and replace it with a modern, speeded up North, already evidencing the new capitalist forms of commerce and communication. To free-traders and entrepreneurs, the passing of the Native days of the North was occasioned by the signing of Treaty 8 . In Edmonton, free-trader Jim Cornwall established the Northern Transportation Company in 1903 to build steamships in competition with the $\mathrm{HBC}$ and was finding partners for the Athabasca Railway Company. ${ }^{23}$ Ottawa's interest, it appeared, had waned in the North since the initial proselytizing of people such as Bell and McConnell, but Edmonton's stake remained high.

\section{'Moving' Pictures}

As they were reproduced and circulated in greater numbers, Mathers' photographs travelled farther and farther from their original production in Edmonton. They were used in increasingly complex and diverse ways, but often to tell a similar story. In a short time, however, Mathers himself was forgotten and ignored; his apprentice Ernest Brown purchased his studio and collection of negatives in 1904. As his images began to appear in more and more places, the narrative control of Mathers' Farmer's Advocate article and

\footnotetext{
${ }^{23}$ MacGregor, Paddle Wheels to Bucket-Wheels, 116.
} 
his souvenir captions faded. Conversely however, the ability of Mathers' photographs to see into the North and to speak for it, increased as the North itself was 'opened' to increasingly diverse and larger numbers of interests.

Ever since his 1906 voyage down the Mackenzie, one of the people actively engaged in the North was Federal Superintendent of Forestry, Elihu Stewart. Dissatisfied with the limitations of language and length placed on his 1907 report to the Senate on the state of northern resources, Stewart published an illustrated account of his voyage in 1913. In the first line of his narrative, Stewart posed for the would-be cameraperson another great challenge of representing the still unknown world of the Far North: "Perhaps no portion of America has received greater attention from the explorer during the last three centuries than the sub-Arctic regions of Canada, and yet they remain practically unknown to the present day. ${ }^{24}$

In the early twentieth century, travel and terrain made image-making still relatively difficult in the North. Joan Schwartz advises scholars of representation to assess photographic records "against the changing context of what was 'photographable'," and the very sub-Arctic landscapes of Canada were no exception. ${ }^{25}$ Stewart prefaced his account with the warning that "Many of these were snapshots taken from the deck of one or other of the steamers on which I was a passenger, and for that reason are not as good as when time exposures were obtained," while Agnes Deans Cameron prefaced her readers with the awareness that, "This is the beginning of a camera nightmare which lasts six months until we again reach Chicago..26 ${ }^{.26}$ The greatest threat

\footnotetext{
${ }^{24}$ Stewart, Down the Mackenzie, 23.

${ }^{25}$ Joan M. Schwartz, "Photographs from the Edge of Empire," in Cultural Geography in Practice, ed. Alison Blunt, et al. (New York: Oxford University Press, Inc, 2003), 165.

${ }^{26}$ Stewart, Down the Mackenzie, preface, Cameron, The New North, 20.
} 
was rain and water damage, as David T. Hanbury discovered when his canoe capsized in a series of rapids while travelling through the Barren Grounds during the summer of 1898 after spending two years living with and photographing the people of the North: "The loss of the geological and botanical collections, on which I had spent much time and trouble, I particularly regret; the loss of an exceptionally interesting collection of photos I deplore."27

In the face of such challenges, Agnes Deans Cameron and her niece were able to secure a number of quality images, and Elihu Stewart managed to produce a number of close-to-terrible pictures. Despite having their own photographs, both of their published accounts drew heavily upon Mathers' stock of images to emplot and illustrate their voyages. This was the result of Mathers' technical abilities, salesmanship, and subject matter. Many of the 1901 images that began to circulate in the pages of later texts were of the indigenous inhabitants of the Far North, although the few pictures Mathers created of the Dene people were totally absent. Cameron preferred to concentrate on the Inuit people, who represented in her mind, the 'true class-conscious Socialist of Karl Marx':

Thus here, under the Northern Lights, do the Farthest North subjects of the Seventh Edward work out in deeds the dream of Sir Thomas More's crescent-isle of Utopia where men lived and worked as brothers, holding all things in common. ${ }^{28}$

Indeed Utopia was a dream. As James Duncan and Derek Gregory suggest of late nineteenth-century travel, "the networks that made escape possible - railways and steamships, hotels and tour companies - ensured that modern tourism was constantly

\footnotetext{
${ }^{27}$ David T. Hanbury, "A Journey from Chesterfield Inlet to Great Slave Lake, 1898-9," s.n. 76.1 (1900): n.p.

${ }^{28}$ Cameron, The New North, 265.
} 
haunted by the spectre of belatedness, by the sense of arriving at the very moment that a non-modern world was fast disappearing under the impress of modernity." 29

Characteristically, as fascination with the Inuit began to reach a fever pitch in the first decade of the new century, newspapers proclaiming 'Esquimaux Dying Off' due to disease had authors and ethnographers rushing northward. ${ }^{30}$ Departing from Athabasca Landing on the newly constructed steamer, Midnight Sun, Stewart remembered meeting one person in particular, the famed Canadian anthropologist Vilhjalmur Stefansson. The Arctic explorer Stefansson had just given an interview to an American reporter visiting the Landing. The antimodern spirit of Whitney and Pike seemed to meld with the scientific integrity of people like Russell and Franz Boas in the figure of Stefansson. The reporter notified audiences of his method and rationale for studying the Inuit, a practice now popularly ritualized:

The longevity of the people on the whole in later years is not great, and the race is fast dying out. In not many years more the Eskimos will have become extinct. Mr. Stefansson will discard all European garments and adopt those of the Eskimos, which he will continue to wear until he again comes out into civilization. ${ }^{31}$

The article, not surprisingly, was illustrated with two Mathers images. In a representation of 'Esquimaux in Their Kayaks,' [Plate 36] the editors imagine Stefansson's voyage into the Arctic regions of Canada. [Plate 44] The disembodied head of the anthropologist hovers squarely above the two Inuit men in their boats, all three framed as devices of their own society: the Harvard professor classically set as a slight profile in the

\footnotetext{
${ }^{29}$ James S. Duncan and Derek Gregory, eds., Writes of Passage: Reading Travel Writing (London and New York: Routledge, 1999), 7.

${ }^{30}$ A common headline, here reprinted from the Winnipeg Free Press, reports steamboat inspector Phillips being amazed at the epidemic results of measles on the north shore of Great Slave Lake. Dawson City is cited as the origin of the disease for the people, and Phillips reported that 80 died on the band's return trip from the prospector town. "Esquimaux Dying Off' Los Angeles Times 13 October 1903: 6.

31 "Sacrifice of Stefansson" Boston Daily 23 September 1906: 6.
} 


\section{SACRIFICE OF STEFANSSON. Member of the Harvard Faculty.}

From Aristocratic Cambridge He Has Gone to the Great White Silence of the North-Left Athabasca Landing on the Midnight Sun With a Camera,.. Rifle and Notebook-Cut Off From Civilization for Two or Three : Years, He will Dress and Live Like the Equimaux, Studying the People- of:That Race.

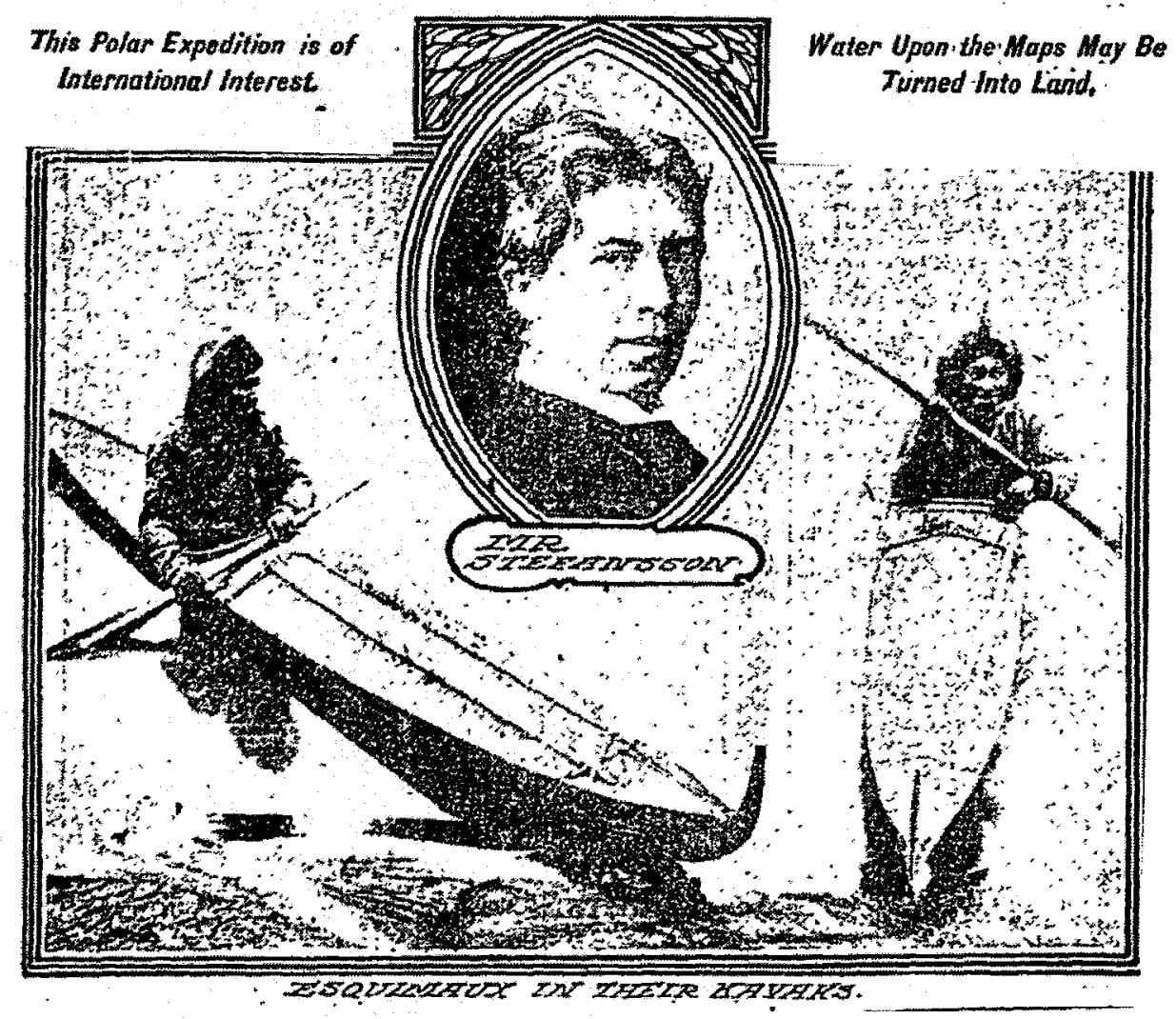

Plate 44: Mr. Stefansson [and] Esquimaux in their Kayaks

Source: "Sacrifice of Stefansson" Boston Daily 23 September 1906: 6. 


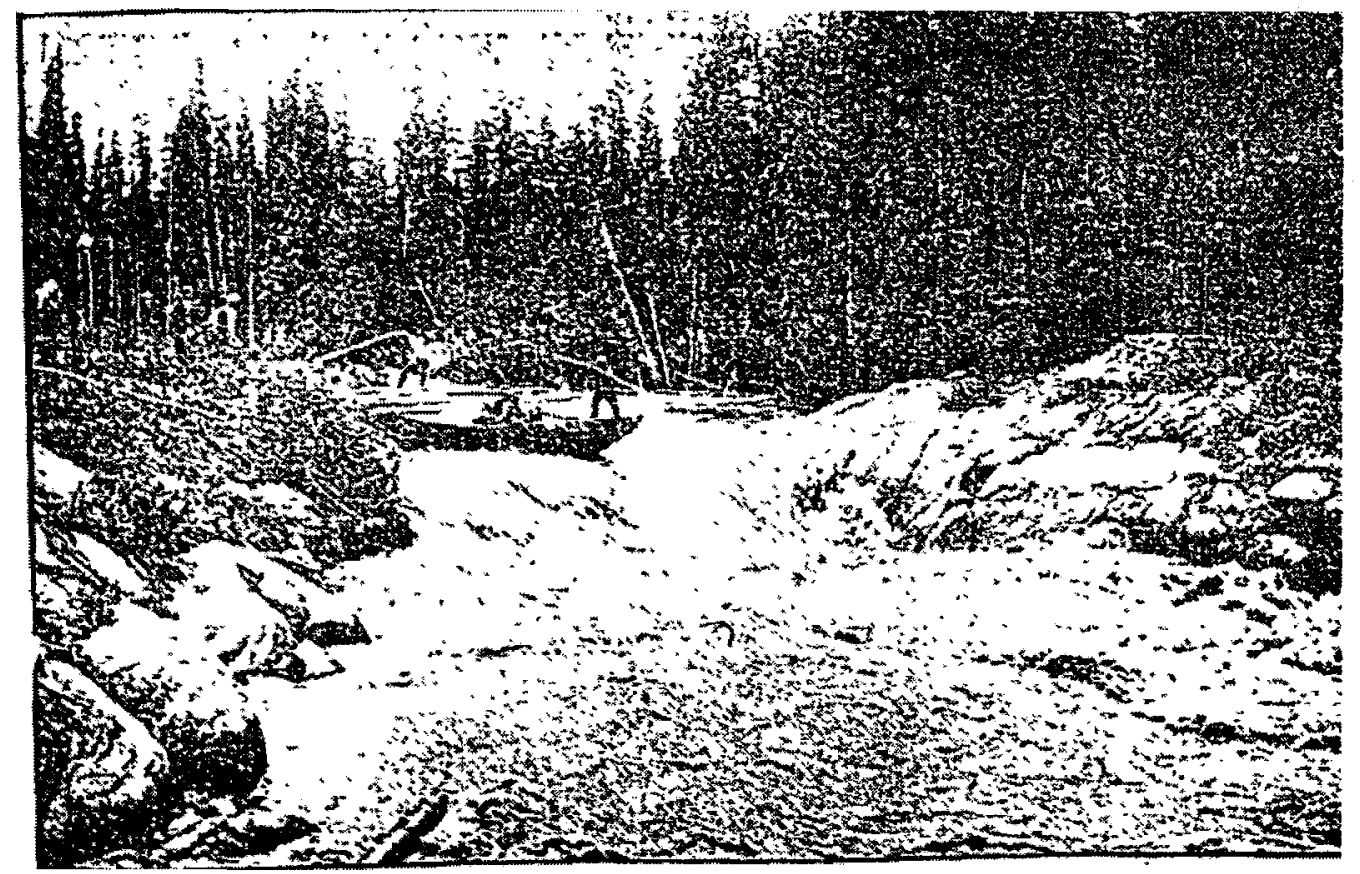

HARVARD MAN. ON HIS. WAY NORTH, SHOT RAPIOS IN A-50-FOOT SCOW.

Plate 45: Harvard Man, on His Way North, Shot Rapids in a 50-Foot Scow Source: "Sacrifice of Stefansson" Boston Daily 23 September 1906: 6. 


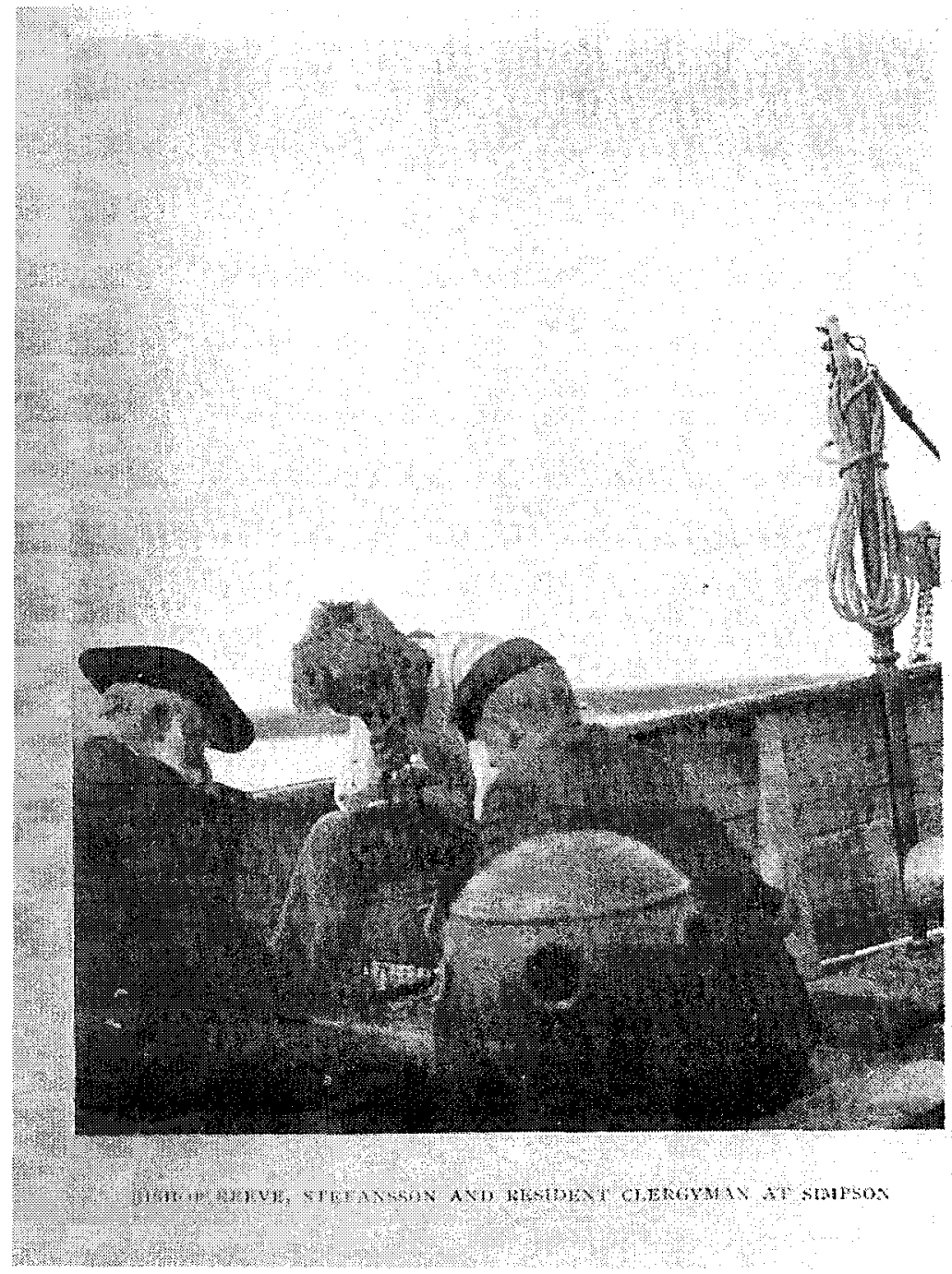

Plate 46: Bishop Reeve, Stefansson and Resident Clergyman at Simpson Elihu Stewart, Down the Mackenzie and Up the Yukon in 1906 (Toronto: Bell and Cockburn, 1913), 90. 
style and border of European portraiture, the Inuit men presented as ethnographic objects. The image invites the viewer to imagine a relationship between the two groups reflecting much deeper assumptions about the experience of the 'other.' Other images simply glorified the rugged masculinity which the North was understood to possess since the time of Whitney and Pike. In one particularly fanciful image, the reporter appropriates a Mathers image from 1901 to depict the 'Harvard Man' shooting a mighty rapid. [Plate 45] There is, of course, no possibility that this was actually Stefansson since Mathers had made the image five years before the anthropologist visited the Slave River.

Nevertheless, the visual metaphor of the photograph was appropriate to popular impressions of the nature of the North.

Elihu Stewart's images of Stefansson tell a different story of adventure and high stakes on the river, highlighting the excruciating boredom of steamboat river travel that despite his glorification of transport - frustrated the forest superintendent.

To give an idea of the delay caused by trying to navigate this portion of the Athabaska with loaded crafts ... I might mention that this morning Mr. Phillips, Inspector of Hulls and Boilers, caught up to us ... thus making the journey in four days, which has taken us twenty to accomplish. ${ }^{32}$

Photographs such as Stewart's 'Bishop Reeve, Stefansson and Resident Clergyman at Simpson' passing the time over a chess board contradicted the image of movement into an 'uncivilized' place, and consequently were rare. [Plate 46]

Photographs that carried the reader away from civilization had deeper resonance with the cultural assumptions of early twentieth-century Euro-Canadians. Supplying Mathers' image of 'Esquimaux in their Kayaks,' Stewart reproduced what was becoming a set of familiar distinctions between the Inuit and Dene people:

\footnotetext{
${ }^{32}$ Stewart, Down the Mackenzie, 7.
} 
when we come to the Loucheaux [Inuit] we seem to have reached a different type and one more closely allied to the eastern Asiatic than to the American Indian. They inhabit the country of the lower Mackenzie, the Porcupine and the lower Yukon. They are of rather small stature and dark colour; are very inquisitive and much disposed to imitate the white man in several particulars. ${ }^{33}$

The second part of Stewart's book continued the categorizing of difference. It classified different Aboriginal groups through their relation to Eurasian typology inside a more elaborate natural history of the Mackenzie and Athabasca districts. Stewart proceeded along the lines of Russell and MacFarlane's work: ranging from chapters I and II on Climate and Soil, through 'VI. Animals,' and finishing with chapters IX through XII on the region's Inhabitants, Half Breeds, The Traders, and Missionaries. Every person or thing had a place in the order of the North as Stewart recorded it. The Dene, meaning "people," were discursively removed from Denendeh - "land of the people" - and reinscribed as "Inhabitants" in a separate rhetorical space. ${ }^{34}$

Mary Louise Pratt's Imperial Eyes: Travel Writing and Transculturation, advances the theory that when written by travellers, natural history may be construed as a narrative of 'anti-conquest' set against the classical conquest story of land discovered, explored, possessed, and settled. ${ }^{35}$ Pratt notes that, conspicuously, some travel writers who were otherwise agents of colonial regimes - Stewart for example being a representative of the Senate in Ottawa - make little reference to their narratives as ordained, colonizing missions made on behalf of the governments they represented, but presented themselves as exploratory naturalists. ${ }^{36}$ Pratt suggests the great attention to classification and explanation - where the writer's "encounter with nature, and its

\footnotetext{
${ }^{33}$ Stewart, Down the Mackenzie, 230.

${ }^{34}$ Abel, Drum Songs, xxxiv.

${ }^{35}$ Pratt, Imperial Eyes: Travel Writing and Transculturation, 38.

${ }^{36}$ Pratt, Imperial Eyes: Travel Writing and Transculturation, 58.
} 
conversion into natural history, forms the narrative scaffolding" - was symptomatic of a

desire to script the 'anti-conquest':

The conspicuous innocence of the naturalist ... acquires meaning in relation to an assumed guilt of conquest, a guilt the naturalist figure eternally tries to escape, and eternally invokes, if only to distance himself from it once again. ... The discourse of travel that natural history produces, and is produced by, turns on a great longing: for a way of taking possession without subjugation and violence. ${ }^{37}$

The same Mathers photographs that subsumed and steadied the uncertain ramifications of modernity in the North by presenting the useful qualities of Native labour and the reassuring, 'uncivilized' other in the Inuit (Chapter 4) were employed by Stewart to steady the 'anti-conquest,' camouflaging his government mission to assess the resources of the country and expedite their expropriation. Following the narrative established by all the similar explorers, Stewart ended the river-based 'down and up' story of expropriation in the North with the Inuit. Although his textual description brought him down the Yukon and into Vancouver, the pre-textual regulations of photographic description established by Mathers ended on the Arctic Circle, reproducing the geographies of difference his photographs were intended to convey. [Plates $47 \& 48$ ]

As shown in Chapter 3, the geographies and distances travelled were envisioned, represented and narrated - using the camera and the gun - as voyages that redeemed the

\footnotetext{
${ }^{37}$ Pratt, Imperial Eyes: Travel Writing and Transculturation, 57. Stewart's long trip down the Mackenzie on the steamer, Wrigley, allowed him to give such ideas consideration. In his popular account, he gave a lengthy description of a mock government designed by the passengers on the boat, set up to redress the banning of liquor under the "tyrannical rule" of the Dominion government in Ottawa. In the passengers" government, HBC superintendent Thomas Anderson was elected Lieutenant Governor, who then promptly assigned the Cree pilot of the Wrigley as Minister of Marine. As the illegal drinking that spawned the pantomime continued, the group soon realized, "that even if the cabinet had not been personally favourable to the free importation of this essential article, it would have been impossible for them to command the confidence of the people unless they passed an ordinance abolishing this legislation." The teetotalling Oliver must have been stunned by Stewart's insurgency. The debauchery continued late into the night until the Euro-Canadian scientists and travellers, finding themselves in a parliament with Native and métis men discussing ideas associated with the Red River Rebellion, promptly ended the discussion and Anderson, "resumed intelligent autocratic control, which he had long exercised over the country." Stewart, Down the Mackenzie, 89-92.
} 
Page Caption

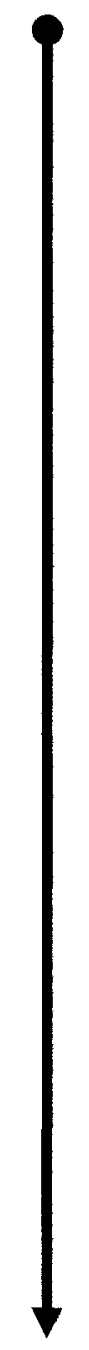

\section{South}

(36) Tracking on the Athabasca River

(44) Grand Rapids on the Athabasca River

(63) Fort Chipewyan on Athabasca Lake

(69) Rapids on the Slave River at the Second Portage

(77) Fort Resolution on Great Slave Lake

(79) Dog-Ribbed Indians at Great Slave Lake

(101) The Ramparts, Mackenzie River

(107) The Midnight Sun

(115) Fort McPherson

(193) Esquimaux in Their Kayaks

(219) A Moose and Indian tepee

(231) Coming in from the North

(254) Trading with the Esquimaux

\section{North}

\section{Plate 47: Anatomy of Recirculation I - Mathers and Stewart}

Photographs by C.W. Mathers appearing (uncredited) in Elihu Stewart's Down the Mackenzie and up the Yukon in 1906: With a Map and Thirty Illustrations from Photographs. 


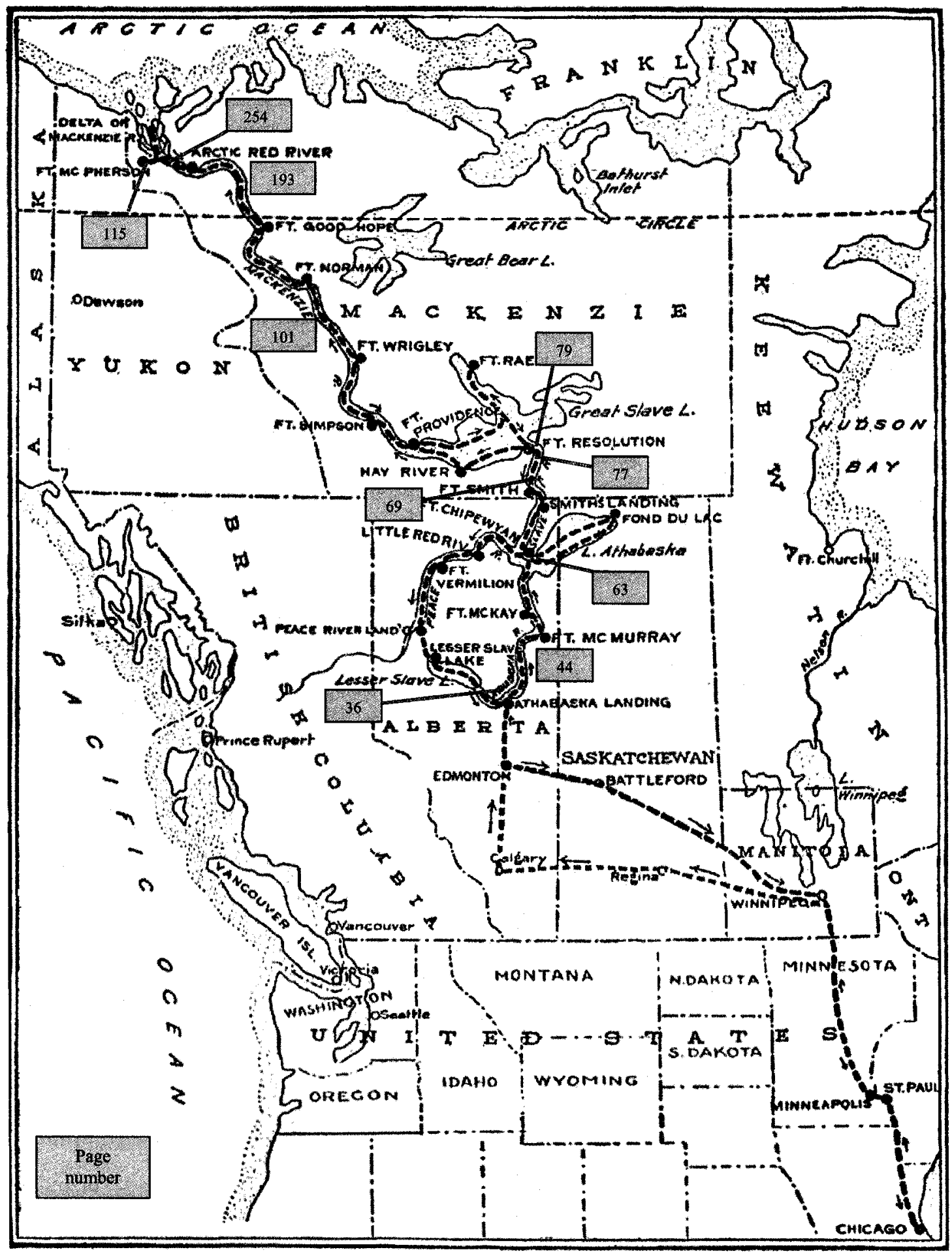

Plate 48: Anatomy of Recirculation II - Mathers, Stewart and Cameron Mathers' 1901, images from appearing in Elihu Stewart's Up and Down the Mackenzie in 1906, plotted by page number onto the map accompanying Agnes Deans Cameron's The New North: Being Some Account of a Woman's Journey through Canada to the Arctic, published in 1909. 
masculinity of the traveller endangered by civilization. Wendy Roy reminds us the "beginnings and ends" that structure masculine narratives are strategic devices, and the photographic cut-off in the North could be evocative of the achievement of a characteristically male antimodern goal..$^{38}$ It is tempting, therefore, to suggest that the upriver travel images that depict Cameron's southward voyage reify her symbolic return to "women's space" and domestic civilization. Indeed, her 'Map of the Author's Route' that opened The New North, clearly indicates the return-voyage of the traveller. This is, however, too simple an explanation. On one hand, Cameron arguably subverted any gendered expectations of her voyage through her account of the southern portion, which detailed the author 'bagging' and photographing her first moose on the shores of the Peace River, then 'discovering' Sir Alexander Mackenzie's camp with her camera:

Mackenzie was the first man to cross the continent from sea to sea north of the latitude of Mexico, it was from this point where we stand that he launched his ambitious canoe. There is no more historic spot on the continent than that on which we stand this September day, and as yet it is all unmarked of commemorative stone or recording tablet. The lost camp had never been photographed until we brought our inquisitive camera to bear upon it. ${ }^{39}$

Inasmuch as Cameron followed the conventions of earlier male explorers - using the gun and the camera as devices to envision her adventure and inscribe the landscape with 'spots' of white Euro-Canadian history - she was also complicit in the practices of power-knowledge that buttressed the ethnographic aspect of the 'anti-conquest.' Both Cameron and Elihu Stewart redeployed Mathers' photographs inside parameters of difference that regulated the contact experience.

\footnotetext{
${ }^{38}$ Wendy Roy, Maps of Difference: Canada, Women, and Travel (Montreal and Kingston: McGill-Queen's University Press, 2005), 98.

${ }^{39}$ Cameron, The New North, 349.
} 


\section{Narratives on Display}

The regulations of display led people to classify and order their world in terms of hierarchies that intersected with one another. Thus, it was possible to read hierarchies of race into certain objects in terms of primitive to 'civilized.' The possibilities of challenging this system would seem to be particularly possible on the frontier of western civilization, where Europeans were forced to work in and alongside indigenous cultures. However, as Ann Laura Stoler has pointed out, it was often the opposite case, and the frontier - where miscegenation most occurred - was the place where trenchant ideas of class and racial hierarchies took place. ${ }^{40}$ Agnes Deans Cameron employed the hierarchical model in relating what it meant to be a 'half-breed' in Canada: "It means much to each on which side of the English Channel his father had birth. When a Frenchman marries an Indian woman he reverts to her scale of civilization; when a Scot takes a native to wife he draws her up to his." ${ }^{\prime 41}$ But the hierarchies European travellers used to explain colonial 'others' were not simply abstract concepts drawn out of a sense of superior civilization. As Raymond Corbey wisely points out, racial hierarchies as such were essentially meaningless without any sense of history:

Narrative plots are as pervasive in the civilizatory, imperialist, missionary, and scientific discourses of the [late nineteenth century] as in the threedimensional spectacles that, to a considerable degree, were governed by these discursive activities. As many contemporary book titles suggest, the history of mankind was narrated essentially as a heroic ascent toward the natural and ultimate goal of cosmic evolution: the industrial civilization of white, European, middle-class citizens of the $19^{\text {th }}$ century. Other races followed the same path, it was postulated - especially in evolutionist

\footnotetext{
${ }^{40}$ In considering 'race' and 'class,' Stoler concludes that neither concept presages the other, but that both were imbued with particular political metaphors about human nature. Stoler, Race and the Education of Desire, 126-30.

${ }^{41}$ Cameron, The New North, 76.
} 
ethnology, which was a scientific manifestation of the discourse on progress - but lagged behind culturally and physically. ${ }^{42}$

The narrative, historical process was what gave power and real meaning to the racist 'civilizing' belief in the primacy of non-Aboriginal European peoples. Corbey maintains that the narrator of cultural difference acts as a conduit to direct 'the gaze' of the powerful observer. His attention to the 'exhibitionary complex' of Tony Bennett where art museums, photographs, textbooks, and exhibitions function as a discursive system that marks and delineates the subjectified other as it shadows and fascinates the subjectifying Cartesian self - presents a 'narrating' vision of power that is situated as a synchronic structure. Thus Agnes Deans Cameron could draw upon other forces of Orientalism to explain her experiences in the Far North, telling readers, "The Mackenzie River Eskimo is, with perhaps the one exception of an Arab I fraternized with in Chicago at the World's Fair, the most splendid specimen of physical manhood I have ever seen." ${ }^{\natural 3}$ Corbey asserts that photography was closely aligned to the primacy of visual perception that was characterized best by the motto of the 1892 Chicago World's Fair - 'to see is to know.' "The role of photography in the complex of practices regarding colonial subjects," argues Corbey, consisted of "collecting, scrutinizing, measuring, categorizing, filing, controlling, [and] narrating. ... While the prospering middle classes of Western industrial societies presented themselves honorifically in self-congratulatory studio portraits, hundreds of thousands of photos of their Others ... functioned in the context of repression." 44

\footnotetext{
${ }^{42}$ Raymond Corbey, "Ethnographic Showcases, 1870-1930," Cultural Anthropology 8.3 (1993): 359.

${ }^{43}$ Cameron, The New North, 215.

${ }^{44}$ Corbey, "Ethnographic Showcases, 1870-1930," 363.
} 
Though Corbey and Bennett's arguments are convincing, Derek Gregory and others have tended to interpret these post-structural theories of subjectivity, largely credited to Edward Said's brilliant Foucauldian genealogy of the Occidental discursive production of 'the Orient' - and hence Orientalism - as primarily concerned with space, "charting the changing constellations of power, knowledge and geography." 45 Spaces of the other were found in people as much as they were in places, and marked in historical and geographical expressions. The geographical aspect of her racial identity dawned on Agnes Deans Cameron as she moved further from Edmonton: "A favourite expression of mine in the latitudes below when the world smiled was, 'Oh, I'm glad I'm alive and white!' On this exclamation I start now, but stop at the word 'white.' North of Athabasca Landing white gives place to a tint more tawny."46 Like many others before her, Cameron also drew upon a powerful discursive ability to animate her movement through space and geographical hierarchies of civilization in her ethnographic material.

While Edward Said provides us with critical tools for unravelling the way the allure of the 'other' and power/knowledge negotiates spatial experience, Derek Gregory correctly points out his "stunning oversight of the visual arts themselves." 47 Said maintained that cultural negotiations are distributed through pre-conceived geographical, Orientalist discourse. This relationship is predicated by an entrenched essentialism East and West. For Said, the maintenance and construction of the European west as rational, controlled, and 'white' was possible only because the 'Orient', or East, was

\footnotetext{
${ }^{45}$ Derek Gregory, "Edward Said's Imaginative Geographies," in Thinking Space, ed. Mike Crang and Nigel Thrift (London and New York: Routledge, 2000), 302.

${ }^{46}$ Cameron, The New North, 55.

${ }^{47}$ Derek Gregory, "Emperors of the Gaze: Photographic Practices and Productions of Space in Egypt, 1839-1914," in Picturing Place: Photography and the Geographical Imagination, ed. Joan M. Schwartz and James R. Ryan (London: I.B. Tauris, 2003), 195.
} 
imagined by Europeans to be irrational, passionate, and 'dark.' In his important study of European tourism and photography in Egypt, Gregory presents the camera as a tool for negotiating space and place in Egypt, showing that sites are not 'given' to either Eastern or Western predominance. The tourist, as a cultural geographer, used photography to map Orientalist meaning onto the ancient world.

\section{Conclusion - C.W. Mathers' Photographs are History}

Both Stewart and Cameron made extensive use of Mathers' photographs in rendering the domination of European civilization over the geographical complexities of the North. Like Mathers, they visualized tracking scows and steam-driven boats as the same narrative of civilization over nature. Their publications transported the message across North America that the Far North was now at the mercy of colonialism.

Joan Schwartz recognizes that the discursive message conveyed by images must be considered through and against its material media form; hence she argues that the materiality of the photograph in circulation serves as a pretext for consumption and viewing. "Analysis of the photograph as a site of agency," Schwartz explains of the way that images carried and activated the space-time meanings described as imaginative geographies,

must also be linked to the circulation and viewing of the image. It must proceed on the assumption that the photograph was seen and, thus, entered and participated - either directly as an object of study, or indirectly as a pre-text of viewing - in the relationship between observer and material reality. The degree to which the photograph was able to help constitute or contest - notions of place and place-based identity was directly related to its ability to circulate, and be viewed - as an individual image, as part of photographic collectivities, in conjunction with words, and in larger documentary universes. ${ }^{48}$

\footnotetext{
48 Joan M. Schwartz, "Agent of Sight, Site of Agency," (Ph.D Dissertation, Department of Geography, Queen's University, Kingston, ON, 1998.), 247.
} 
Cameron and Stewart turned to Mathers when they needed to express the relationship between the traveller and the physical landscape, to translate material reality for the reading viewer. They did so especially on the three rivers that took them to the Arctic: the Athabasca, the Mackenzie, and the Slave. The latter presented a churning stretch of whitewater as it left the northwest corner of Lake Athabasca before steadying its flow into Great Slave Lake. While the scows shot most of the rapids empty, traders heading north would portage goods using the ox-train between Smith's Landing on the Lake Athabasca and Fort Smith where the Slave River settled. Mathers' oft-reproduced photograph, 'On the Slave,' captures a scow perched at the edge of a particularly steep whitewater ledge. [Plate 49] Included in Stewart's travel account, the men observing from the shore contrast and contribute to the impression of daring and skill of the riverboat workers; they are caught, like the cameraman, in the enchanting suspense of the moment - "what will come of this?"49

When the travellers borrowing Mathers' reproduction reflect on the image, however, they are well aware of the outcome of the scene. On his way past the falls in 1906, Stewart could only expound that "this will be spanned one day by an electric tramway, the motive power for which can easily be obtained from the rapids near by." ${ }^{, 5}$ In more definite terms, Cameron supposed that surely there was "enough 'white coal' rushing by us to turn the wheels of the factories of a continent." ${ }^{, 51}$ In some places however, engagement with the river resisted the power of both human agency and imagery at once, as elicited in Cameron's description of tracking:

\footnotetext{
${ }^{49}$ See Plate 1 and Plate 45

${ }^{50}$ Stewart, Down the Mackenzie, 71.

${ }^{51}$ Cameron, The New North, 177.
} 


\section{DOWN THE MUCK WNZIF}

season was dear and blue. The valley, whol is here orer two miles mide, about one nalle on each side of the stream itsel, is six on seven lundred leet lower than the table land aboye.

On the way in from Lesser Slave Lake I had been told to have my camera ready as we approached the descent at Peace Hiver Crossing. Even the stolld hal bred whe accompanied rne was almost enthusiastic in his desewption of the view that awated us, so that I was quite prepared for whet $I$ spprehended would be something like the view of Niagara River from Queenston Teights. It resombled more the Grand Canyon of Arizona. All at once there appeared before us something so gigantic in its dimensions and so bewildering in the beaty of the rista which it revealed, that I leel any words that I can pen fould rather conceal than peveal any trie conception of this rondertul poture, Looking from the upland in every direction and on both sides of the ralley, the table land secmed to the eye as level as the proverbial billiard table, while beneath and extending east and west for distances which $I$ hesitate to estimate, lay 68

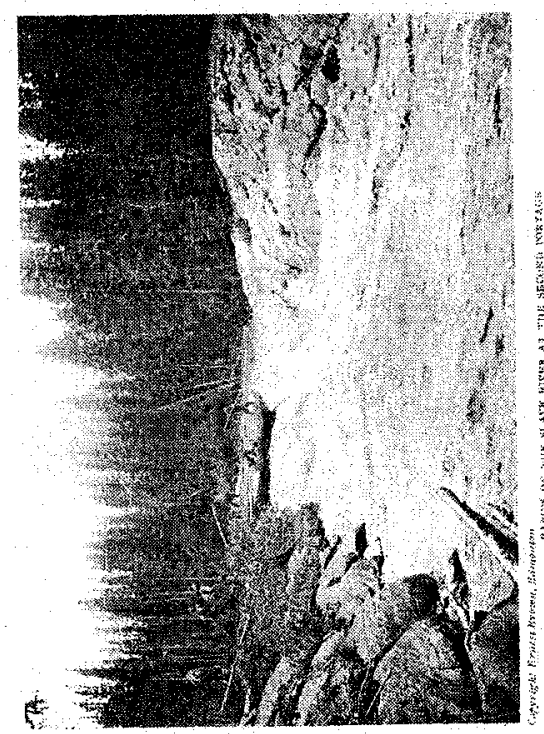

Plate 49: Rapids on the Slave River at the Second Portage

Source: Elihu Stewart, Down the Mackenzie and Up the Yukon in 1906 (Toronto: Bell and Cockburn, 1913), 68. 


\section{THE NEW NORTH}

other end. There is something uncanny about it, and our stock goes up.

We confess to being a little homesick as we wave farewell to the half hundred passengers in the familiar scows embarked for their two hundred and thirty-eight mile journey th the Athabasca. It will be a tiresome enough trip. though, for every foot of the way the big boats will have

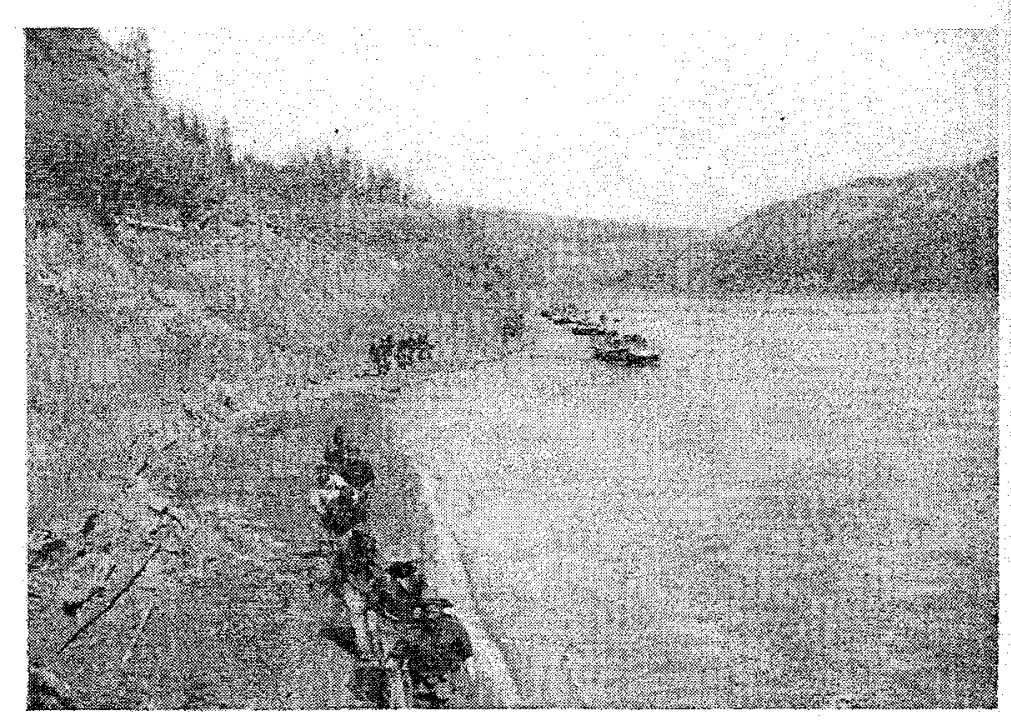

Starting tip the Athabasca

to be tracked (towed) by teams of hali-breeds scrambling along the shore, now on land, now splashing in the water. The party will have the mosquito as companion on the sorrowful way and it will take them four weeks to make Athabasca Landing, the distance which in the spring we dropped down in little over a week. We send letters home, and with hand-shaking all round bid farewell to Mr. Wyllie, the Grey Nuns, and the rest.

\section{Plate 50: Starting up the Athabasca}

Source: Agnes Deans Cameron, The New North: Being Some Account of a Woman's Journey through Canada to the Arctic (New York \& London: D. Appleton and Company, 1910), 322. 


\begin{abstract}
All northern rivers are navigated against stream by 'tracking', that is, towing the boats, weary mile after mile, 'by the power o' man,' the halfbreed boatmen scrambling now on the bank, now in the water, tugging the heavily-laden craft after them. It is a mode of transportation that neither written word nor camera can do justice to. ${ }^{52}$
\end{abstract}

Despite such pronunciations, Mathers' images were inserted seamlessly into Cameron's narrative. [Plate 50] In recirculation, his photographs showed the river had been tamed and brought to the service of civilization. ${ }^{53}$ Stewart was so moved by the powerful symbolism of the gorge at Peace River Crossing that he could not help but prophesize the meaning of it:

At the source of the Danube River at Donoueschingen stand two statuary figures, the one representing the country and the other, the river. The former is indicating to the latter the route to be taken, and the injunction is "Go this way and open the wilderness." Here we have a valley even greater than that through which the Danube flows, and the injunction is being obeyed in the opening up of a region of inestimable value for the benefit of those who will yet seek their homes in this part of our possessions. ${ }^{54}$

Stewart illustrated his powerful thoughts about the Peace River with the 'Tracking' image that Cameron had used above. In conjunction with their enduring function in egalitarian science and continual usage in explaining the scopic regimes of modern racist hierarchies, Mathers' photographs during the early twentieth century were being presented as the drama of the great opening of the North.

In greater numbers than Stewart or Cameron, Agnes C. Laut recirculated Mathers' images retelling the dramatic story of Northwest exploration, where they lost their original associations. In Pathfinders of the West, 'Fort Resolution on Great Slave Lake' became Pierre de la Verendrye on the Mississippi; 'Esquimaux in their Kayaks' greeted

\footnotetext{
${ }^{52}$ Cameron, The New North, 88.

${ }^{53}$ See Plate 31

${ }^{54}$ Stewart, Down the Mackenzie, 70.
} 
Samuel Hearne in the Arctic; 'Trading with Eskimo, Ft. McPherson' accompanied the voyages of Mackenzie and Lewis and Clarke found themselves illustrated by "Tracking up the Athabasca."55 Mathers' images were incorporated into additional Laut publications, the names of which are largely self explanatory: Canada: The Empire of the North and Conquest of the Great Northwest.

Though Mathers' photographs were featured in Laut's volumes, she never engaged with them directly, preferring to let the images support the story instead of leading it. Maurice Samuels theorizes that, in history books with images, illustrations allow "for multiple and simultaneous levels of discourse, in which the visual relates to but does not entirely mirror the verbal." 56 For this reason, Samuels explains, engravings and photographs in history books functioned both metaphorically and metonymically - as stories in their selves or as symbolic allusions to larger discourses. In the same way a ring going on a finger metonymically acts to signify marriage for the viewer then, photographs of fur traders shooting the rapids of northern rivers signified the opening of the North and the fulfilment of a heroic national awakening. Images thus reduced to synecdoches could be pared down and reconstituted.

In the sketch, 'Tepees dotted the valley' from Laut's Pathfinders of the West, an artist has separated and moved the original subjects of Mathers' 'Cree Indians' into the background in order to describe an encounter between Radisson and the Sioux. [Plates $51 \& 52]$ Beyond the markings of colonialism, the image bears the inscription of its troubled past in a capitalist world of mechanical production. After Mathers credited

\footnotetext{
${ }^{55}$ Laut, Pathfinders of the West, 230-320.

${ }^{56}$ Maurice Samuels, "The Illustrated History Book: History between Word and Image," in The Nineteenth Century Visual Culture Reader, ed. Vanessa R. Schwartz and Jeannene M. Przyblyski (London and New York: Routledge, 2004), 240.
} 


\section{PATHFINDERS OF THE WEST}

while busy with plans for his hazardous and thankless quest, he died suddenly at Montreal.

Rival fur traders scrambled for the spoils of the Manitoba and Missouri territory like dogs for a bone. De la Jonquière had become governor. Allied with him was the infamous Bigot, the intendant, and those two saw in the Western fur trade an opportunity to

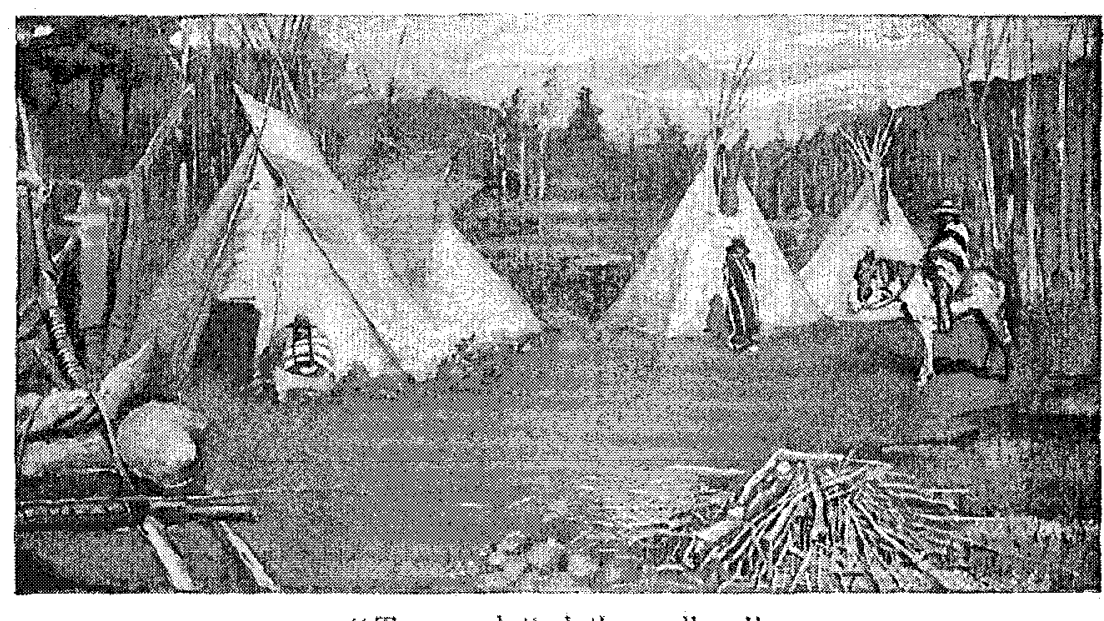

"Tepees dotted the valley."

enrich themselves. The rights of De la Vérendrye's sons to succeed their father were entirely disregarded. Legardeur de Saint-Pierre was appointed commander of the Western Sea. The very goods forwarded by De la Vérendrye were confiscated.

But Saint-Pierre had enough trouble from his appointment. His lieutenant, $M$. de Niverville, almost lost his life among hostiles on the way down the

\section{Plate 51: "Tepees dotted the valley."}

Source: Agnes C. Laut. Pathfinders of the West: Being The Thrilling Story of the Adventures of the Men Who Discovered the Great Northwest (New York: The MacMillan Company, 1904), 236. 


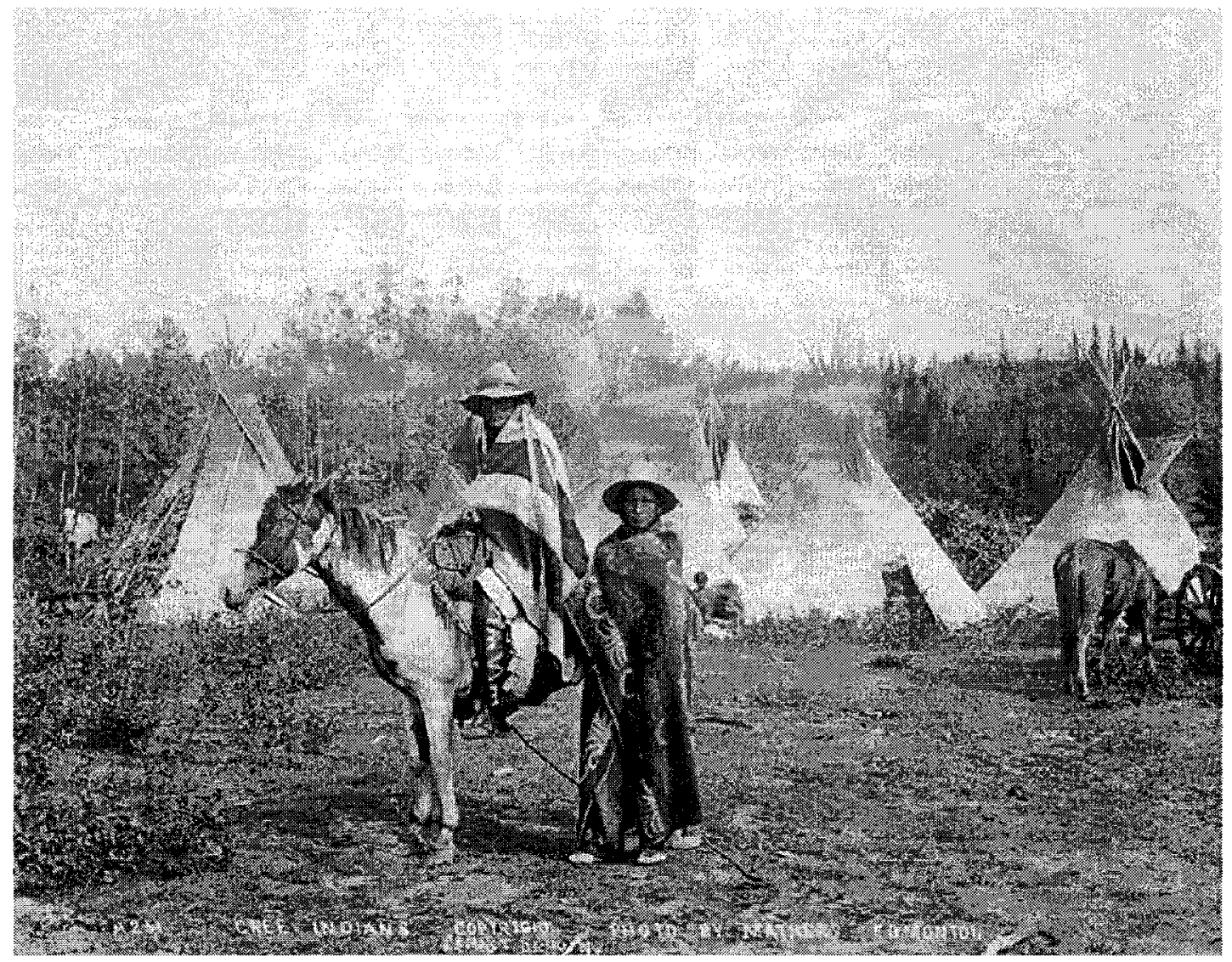

\section{Plate 52: M251 Cree Indians}

Source: C-005101 Ernest Brown Collection (LAC) 1947-009 NPC 
himself for shooting an image that W.H. Boorne had actually made in the 1880 s, his assistant, Ernest Brown, bought the studio and all its images in 1904 and made every effort to enforce his possession over the far-flung images.

While it is probable that Stewart and Cameron purchased their Mathers images from his studio in Edmonton, whether Laut acquired Mathers' images herself or received them is unclear. In Pathfinders, she credits Miss Talbot, a friend from Winnipeg, for "a most complete set of photographs relating to the fur trade.":57 The eminent historian Lawrence Burpee, who also recirculated many of Mathers' images, credits Robert Bell for many of the photographs illustrating his two-volume 1907, The Search for the Western Sea, a compendium of historical text, maps, etchings and photographs that speaks to the massive archive of information available on the Northwest. It is highly likely that in preparing The Search for the Western Sea, Burpee received information about the North from his two colleagues, Robert Bell, appointed to Acting Director of the GSC and R.G. McConnell, then Deputy Minister of the Interior. The initiative Bell had begun in 1882 to harness the natural petroleum reserves of the North was thus being connected to broader narratives about history and geography in Canada. And Mathers' photographs were operative representations in pairing and reasserting the story of modernization, the vanishing Indian, the progressive exploitation of resources, and the place of river routes such as the Athabasca-Mackenzie system in an imaginary Northern experience that was grounded by white masculinity and a national Canadian consciousness described as the "northward course of empire. ${ }^{58}$ In the 1920 s, Laut would explain the tracing of the Canadian national consciousness as "following a river back

\footnotetext{
${ }^{57}$ Laut, Pathfinders of the West, xv.

${ }^{58}$ Vilhjalmur Stefansson, The Northward Course of Empire (New York: MacMillan, 1922),
} 
from the ocean to its mountain springs. From the silt borne down on the flood-tide you can guess the fertile plains watered ... [the] regions of eternal snow and glacial torrent warring turbulently ... [and] the eternal striving, the forward rush and the throwback." 59 Burpee likewise began his 1907 tome with a fifty-page introduction focusing on the rivers of Canada that would have made Robert Bell and Charles Mair equally proud.

A thousand years ago the Northmen, responding to that mysterious attraction which has exercised such a compelling power over men of Aryan blood, pushed their way across the Atlantic to Iceland, from Iceland to Greenland, and from Greenland to America .... . It may perhaps be defined as the spirit of adventure of a vigorous people acting upon a deep-rooted racial tendency to follow the path of the sun. ${ }^{60}$

Once safe upon the shores of the new continent, Burpee continued to describe every major watershed and river system in Canada from the earliest point in the East to contemporary Canada in the Northwest, placing the Mackenzie before the St. Lawrence in his appraisal of the greatest rivers of the continent. Burpee attributed the opening of the North to the officers of the GSC and their "invaluable series of reports ... as to the character of this broad country, its physical features, resources, history, its fauna and flora, its native inhabitants and their manners and customs."

Burpee wrote his history with the same utilitarian approach to knowledge that Roderick Mackenzie offered his natural histories, and narrated them with the same photographs and maps of greater and greater detail. The coalescence of history, geography, geology, and photography in the production of a transcontinental nation was

\footnotetext{
${ }^{59}$ Agnes C. Laut in Valerie Legge, "Heralds of Empire: Liminal Heroes and Visionary Fugitives," International Journal of Canadian Studies 15 (1997): 48.

${ }^{60}$ Lawrence Johnston Burpee, The Search for the Western Sea: The Story of the Exploration of NorthWestern America. Volume I\& II (1908; Toronto: The MacMillan Company of Canada, Ltd, at St. Martin's House, 1935), xiii.

${ }^{61}$ Burpee, The Search for the Western Sea, 583.
} 
well underway before Innis postulated that rivers were communication routes that gave shape to Canada. Along with Agnes Laut, the recirculation of Mathers' images in these texts helped predict nothing less than the Canadian nation as a dormant entity 'waiting' to manifest itself through a northern geography or be created there.

The broad intellectual pattern through which Innis, and those who followed his structural, economic approach to Canadian history, wrote through must be brought to bear vis-à-vis this intellectual precursor. Indeed, Matthew Evenden has shown that "the territorial aspect of Innis's nationalism intersected with a long tradition of treating the North as a site of national imagining." ${ }^{.62}$ In his pre-eminent claim that the land became Canada "not in spite of geography, but because of it," system of the environmentalist approach to history with a concept of Canada he understood to be a 'process,' thus animating a geographical signifier and fixing a historical signified. In the same theory that justified the study of Canada as a fixed category of analysis, Innis mobilized a latent sign that could be re-scripted and reified as myth. ${ }^{64}$ Thus, it is not difficult to understand why John Wadland concludes that "Each Innis text - whether examining the cod fishery, the fur trade, forestry, agriculture, mining, hydroelectricity - is couched in cultural insights marrying biology, geography,

\footnotetext{
${ }^{62}$ Matthew D. Evenden, "The Northern Vision of Harold Innis," Journal of Canadian Studies 34.3 (1999): 164.

${ }^{63}$ Harold A. Innis, The Fur Trade in Canada: An Introduction to Canadian Economic History (New Haven: Yale University Press, 1930), 397.

${ }^{64}$ By 'myth', of course, I mean the Roland Barthes' putting-into-practice of Nietzche's famous aphorism, "truths are illusions about which we have forgotten that is what they are"; to which Barthes offers myth, which, semiology has shown, "has the task of giving an historical intention a natural justification and making contingency appear eternal." Roland Barthes, Mythologies (New York: Hill and Wang, 1972), 142.
} 
economy, history, even the arts, in connecting patterns reflecting eclectic reading and an intensely felt sense of place. ${ }^{.65}$

${ }^{65}$ John Wadland, "Great Rivers, Small Boats: The Environment in Canadian Historical Culture," in Changing Parks: The History, Future and Cultural Context of Parks and Heritage Landscapes, ed. John Marsh and Bruce Hodgins (Toronto: Natural Heritage Press, 1998), 4. 


\section{Chapter 6: Conclusion}

\section{Images, Narratives, and Power}

In her study of early photography and the American West, Martha Sandweiss argued that "photography did not instantly change the ways Americans understood the West. Indeed, Americans' pre-existing visions of the West shaped, to some extent, how photographs of the place would be made, marketed, and understood." Similarly, Mathers' images and those of the many other photographers who photographed the area between Edmonton and the Arctic Sea did not perpetrate the 'opening of the North.' The myriad cultural abilities of photographs are well-described. They 'record' the material past; they reflect the individual concern of the photographer; they narrate larger stories about the world in which people lived; they have become the vaults of memory; they have inspired growth and fostered discovery; they are desire, loss; and photographs and photographers have also participated in the violent erasure of all these things. Indeed, a great deal of evidence lends support to Sandweiss's assertion that ultimately it is the text that animates photographs and makes them speak that should be considered the place where power resides, but other scholars suggest that a different approach is possible.

Art historians and students critical of photography as a signifying process often point to Roland Barthes' adaptation of Ferdinand de Saussure's semiology as the critical framework through which photographs may be read. Barthes' early work presented that a photograph was essentially a signifier, a material image that, much like a word, denoted a mental concept or signified meaning. The a priori structural meanings of compositional elements in photographs, such as a black soldier saluting the tricolore on the front cover

\footnotetext{
${ }^{1}$ Sandweiss, Print the Legend, 3-4.
} 
of Paris Match, could signify complex messages - the stability of imperial French nationalism - and give such myths a "historical contingency" that kept them unquestioned as long as they re-informed the originating structure. Barthes' later work reversed the binary logic where the word or image could be read inside a pre-existing structure to signify meaning and knowledge when he began to suggest that the structure itself is determined by pre-existing knowledge of signified meaning. The beginnings of post-structuralist Barthes are best explained in his assertion that, regarding the photograph, "the power of authentication takes precedence over the power of representation." 2 Truth then, or the signified presence of it in a photograph, determines the structural organization of the reading - 'I must believe what I see.' For historians, Michel Foucault and Jacques Derrida would take post-structuralism to dizzying extents as the course of their scholarly work began to suggest that the western world itself was metaphysically 'always already' given to the concept of absolute meaning, or truth. The shifting fields of power and the 'slippage' of meaning in signifier and language thus represents endless gesticulation around a concept that has no intrinsic value in and of itself. In the historical academy this thinking eventually led to the 'new cultural history,' and, armed with a post-modern scepticism towards absolutes, historians embarked on the study of language and cultural 'texts' in the aptly named linguistic turn. Historians of mentalities were now equipped with the knowledge that, according to Lynn Hunt, "all practices, whether economic or cultural, depend on the representations individuals use to

\footnotetext{
${ }^{2}$ Barthes, Camera Lucida, 89.
} 
make sense of their world." When extended to photography, we hear Allan Sekula explain:

The claim for semantic universality depends on a more fundamental conceit: the belief that photography constitutes a language in its own right. Photography, however, is not an independent or autonomous language system, but depends on larger discursive conditions, invariable including those established by the system of verbal-written language. Photographic meaning is always a hybrid construction ... the photograph is invariable accompanied by; and situated within, an overt or covert text. ${ }^{4}$

In Picture Theory, W.J.T. Mitchell takes this 'linguistic' argument beyond the visual turn, arguing that photography "is and is not a language." For Mitchell, this means that on one hand, photography is simply another way of mediating the otherwise arbitrary connection between 'the word' and 'the thing.' But Mitchell also theorizes that "language is and is not a photography," suggesting that the spaces of vision and difference are a powerful and indispensable organizing pretext for all representation. ${ }^{5}$ The text, whether it is Allan Sekula's signifying linguistic structures or Martha Sandweiss's captioned narratives of colonial power, is not solely where the power to produce visual meaning resides. For Mitchell, the dual status of language-photography and photography-language creates a power system of 'mutual resistances' where meaning is contested and enabled between the text and the image. As James Opp has shown in his recent analysis of Ernest Brown's purposeful re-inscription of 'collective memory' onto C.W. Mathers' photographs, mutual resistances can explain how captioned descriptions

\footnotetext{
${ }^{3}$ Lynn Hunt, "Introduction: History, Culture, and Text," in The New Cultural History, ed. Lynn Hunt (Berkley: University of California Press, 1989), 19.

${ }^{4}$ Allan Sekula, "The Traffic in Images," Art Journal 41.1 (1981): 16.

${ }^{5}$ W.J.T. Mitchell, Picture Theory (Chicago: The University of Chicago Press, 1994), 281.
} 
can be considered 'textual incursions' that did not animate 'mute' images, but were instead "an attempt to reign in unruly photographs."6

While Mitchell presents a strong argument that can explain the place of Mathers' 1901 photographs circulating in a disparate and yet focused variety of texts, I want to add, drawing from Innis, Harris, and Schwartz, that mutual resistances are best understood as the interplay between the land of the people of the North - Denendeh, the Athabasca-Mackenzie river system itself - and the concerted effort to 'picture place.' Photography from 1880 to the beginnings of the twentieth century, like Bell's lantern slide, may be understood as a changing set of narrating practices of power of centralized metropolitan possession and exploitation, establishing and compressing time-space coordinates in order to expropriate local meanings and consolidate the fractured narratives of a modern colonial system. In this respect I concur with William Buxton's argument that "Innis' main concern was how civilizations addressed the problems of ensuring territorial control (in space) and duration (through time)."

In the 1930s, reminiscing over the "last year in which the scow brigades carried northward to Lake Athabaska the season's freight of Chipewyan and the Slave and Mackenzie river posts," GSC officer, historian, and museum co-ordinator Frederick Alcock illustrated his Canadian Geographical Journal article with Mathers' photograph 'Tracking up the Athabasca River. ${ }^{8}$ The year was 1914 and the 'last' scows travelling downriver were carrying four separate groups of GSC surveying and scientific

\footnotetext{
${ }^{6}$ James Opp, "Photographs and Public Memory in Prairie Canada," (paper presented at the Collective Memory and the Uses of the Past: An Interdisciplinary Conference, University of East Anglia, Norwich, UK, 7 July 2006).

${ }^{7}$ William J. Buxton, "Time, Space and the Place of Universities in Western Civilization: Harold Innis" Plea," International Journal of Canadian Studies 15 (1997): 37.

${ }^{8}$ Frederick J Alcock, "Scow Brigade on the Athabaska," Canadian Geographical Journal 1932; 174.3 (1967): 92 .
} 
reconnaissance teams. Many of them, including the party's leader, Charles Camsell, who was born on the Mackenzie, had been to the Far North numerous times. This time, however, they travelled to a different place. The year before, in order to halt private enterprise from developing the area, Ottawa had officially placed a ban on speculative ventures over the bituminious Athabasca oil sands Robert Bell had described thirty years earlier. Effectively extinguishing provincial control in the region for the next thirty years, the Mines Branch of the Department of the Interior sent Sidney Ells to Fort McMurray in the summer of 1913 to take core samples and assess the possibility of drawing oil from the country. ${ }^{9}$ Ells concluded that oil could be extracted from the bituminious sands and that the tar could be used for paving asphalt roads. ${ }^{10}$ By 1919 his conclusions were fact. While the great agricultural settlement scheme of the North would vanish with the beginning of World War I, the rise of the combustion engine in the postwar economy helped propel the Athabasca and Mackenzie regions into the future Bell had predicted in 1882. Since that time, outside and inside interest has not abated in the North, as the initial power-struggle between Alberta and Ottawa gave way to massive provincial development schemes after World War II and eventually the growth of competitive markets in the mid-1980s in the era of globalization and free trade. ${ }^{11}$ Paul Chastko now tells us that

The volume of recoverable oil in the sands is so large that when technological advances prompted the Alberta Energy Utilities Board to include the oil sands as part of Canada's 'proven resources' in 2002,

\footnotetext{
${ }^{9}$ Paul Chastko, Developing Alberta's Oil Sands: From Karl Clark to Kyoto (Calgary: University of Calgary Press, 2004), 7.

${ }^{10}$ Barry Glen Ferguson, Athabasca Oil Sands: Northern Resource Exploration, 1875-1951 (Edmonton:

Alberta Culture, Canadian Plains Research Centre, 1985), 23.

${ }^{11}$ Chastko, Developing Alberta's Oil Sands, 197-230.
} 
OPEC's share of world petroleum reserves dropped dramatically from 79 to 68 per cent. ${ }^{12}$

Whether it was Edmonton or Ottawa that won the greatest gains in the final 'opening of the North' seems at present unimportant. As Chastko points out, Canada's northern oil industries continue to expand despite a chronic inability to meet Kyoto protocol emission reduction levels. ${ }^{13}$ J.M.S. Careless believed that metropolitan centres are the formative sites of identity, and that the frontier has no chance of talking back to the powerful centre. The idea that the metropolitan centre was ruler of the frontier, and that the metropolis serves as ruler of the smaller metropolis is a potent explanation, especially in this case. Through technologies of knowledge, photography well-situated amongst them, the Athabasca-Mackenzie frontier was conceptualized and communicated in the midst of changing into a progressive, productive, modern place. Critiquing this form of historicism, Timothy Mitchell notes, "Elements that appear incompatible with what is modern, Western, or capitalist are systematically subordinated and marginalized, placed in a position outside the unfolding of history." 14 A reassessment of the history of photographic practice in the Athabasca-Mackenzie basin, however, must agree with Mitchell when he notes that, "in the very processes of their subordination and exclusion ... such elements infiltrate and compromise that history." 15

In Chapter 2 I demonstrated how the initial engagement between photography and the region resulted in a representational lag in the ability to produce images of the North that successfully captured early prospects seen by Robert Bell and R.G. McConnell

\footnotetext{
${ }^{12}$ Chastko, Developing Alberta's Oil Sands, xiii.

${ }^{13}$ Chastko, Developing Alberta's Oil Sands, 231-242.

${ }^{14}$ Timothy Mitchell, ed., Questions of Modernity (Minneapolis and London: University of Minnesota Press, 2000), xiii.

${ }^{15}$ Mitchell, ed., Questions of Modernity, xiii.
} 
during the $1880 \mathrm{~s}$. Chapter 3 concentrated on the $1890 \mathrm{~s}$, and showed how interest in the North rose because it was seen as unknown and unknowable and therefore uncivilized, and how antimodern sentiments ultimately reaffirmed photography's status as a modern technology of vision. My analysis then turned to exploring how the photographs Charles Mathers created in 1901 were both agents and locations of change. Chapter 4 explored Mathers' images as agents in fixing racial stereotypes that cast the indigenous Aboriginal peoples of Denendeh as disappearing savages, and as locations that re-organized the land: situating it as a modern site of expropriation and exploitation. ${ }^{16}$ Chapter 5 explained how photographs, implicitly connected to earlier narratives of race and modernity were incorporated into a general scheme of knowing the North that transgressed disciplines in the name of a transcontinental nation, and how the water-borne narrative of Canada from colony to nation was not the product of academic historical contemplation, but a simultaneous development unto itself. Finally, I have tried to show that the most important function photography had in the northern districts was the alienation of the land and successful representation of the North as an open, historically justified, resource. As John Wadland comments on the metropolitan thesis:

$[F]$ rontier landscapes, seen from the vantage point of urban valuation, have no intrinsic value; they find redemption in the ways by which they contribute to the creation of capital. Very much as our use of the word 'environment' accords second place to nature, privileging the 'us' environed, the metropolis/hinterland dialectic effectively diminishes nonurban space, making it merely a supplier to a reality in which it, itself, is not equally a participant. When hinterland ceases to be useful to the metropolis it does not move on to become a Turnerian agrarian landscape. It stops dead in its tracks, awaiting its recovery by the wilderness. ${ }^{17}$

\footnotetext{
16 'Sites of agency, agents of sight' as described by Joan Schwartz.

${ }^{17}$ Wadland, "Great Rivers, Small Boats," 9.
} 
What Wadland does not tell us, and no historian can know, is what happens when interest in the hinterland grows unabated and uncontrolled. If photographs can be agents of change in one direction, can they be in another? [Plate 53] 


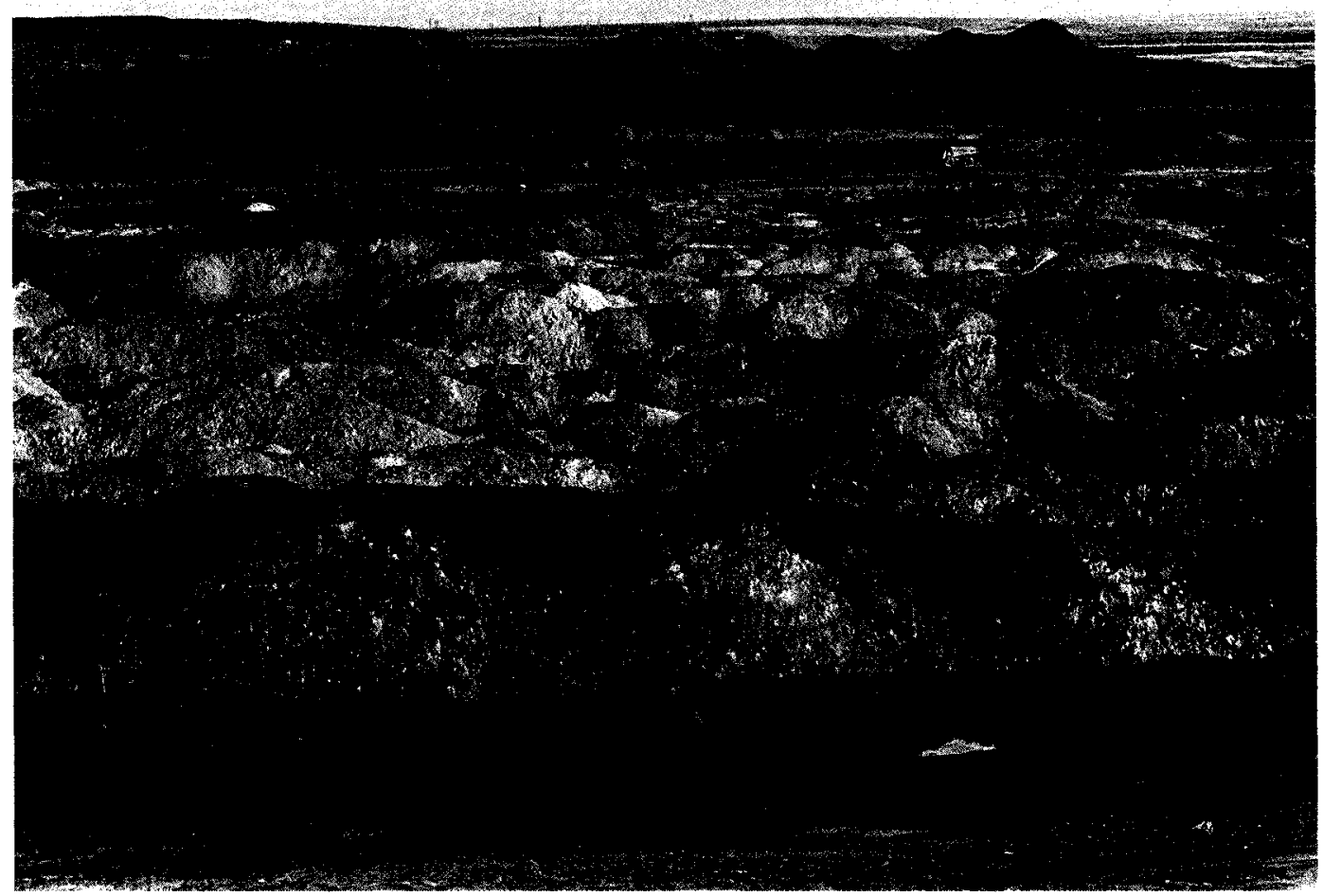

\section{Plate 53: Oil Fields No. 24}

Source: Edward Burtynsky, photograph, Oil Sands, Fort McMurray, Alberta 2001. Image Courtesy: Nicholas Metivier Gallery, Toronto 


\section{Bibliography}

\section{Archives}

Canada. Department of Indian Affairs and Northern Development Collection (LAC) 1961-018 NPC

Department of the Interior Photographic Reocrds (North West Territories) (LAC) 1936$271 \mathrm{NPC}$

E. Brown Collection (PAA) PR1965.124

Ernest Brown Collection (LAC) 1947-009 NPC

Legislative Library Collection (PAA) 1974.1

Minnesota Historical Society Collection (LAC) 1963-092 NPC

A. Povey Collection (LAC) 1987-073 NPC

R.G. McConnell, Athabasca Album (LAC) 1970-088 NPC

Robert Bell Album (LAC) 1963-058 DAP

Robert Bell Collection (LAC) 1984-318 NPC

Robert Bell Fonds (LAC) MG29 B15

Roderick MacFarlane Fonds (LAC) MG29 A11

\section{Government Documents}

\section{Geological Survey of Canada.}

Annual Report, 1890-91. Prepared by S.E. Dawson. Ottawa: Queen's Printer, 1893.

The Mackenzie River Basin. Prepared by Charles Camsell and Wyatt Malcolm. Ottawa: King's Printer, 1919.

Report of Progress for 1880-81-82. Prepared by Alfred Selwyn. Montreal: Dawson Brothers, 1883. 
Report of Progress, 1882-83-84. Prepared by Alfred Selwyn. Montreal: Dawson Brothers, 1885.

Report on a Portion of the District of Athabasca Comprising the Country between Peace River and the Athabasca River North of Lesser Slave Lake. Prepared by R.G McConnell. Ottawa: Queen's Printer, 1893.

Report on an Exploration in the Yukon and Mackenzie Basins, N.W.T. Prepared by R.G. McConnell. Montreal: William Foster Brown \& Co., 1891.

Report on Part of the Basin of the Athabasca River, North-West Territory: 1882-3.

Prepared by Robert Bell. Montreal: Dawson Brothers, 1884.

Summary Report of Progress for 1866-69. Prepared by William Logan. Ottawa: Queen's Printer, 1869.

\section{Government of Canada.}

North-West Mounted Police Patrol. Athabaska District, Winter 1896-97. Prepared by A.M. Jarvis. Ottawa: Government Printing Bureau, 1897.

Report of the Select Committee of the Senate Appointed to Enquire into the Resources of the Great Mackenzie Basin. Prepared by John Schultz. Ottawa: Queen's Printer, 1888 .

Order in Council for Commission Setting up Treaty 8. P.C. No. 2749. Prepared by R.W. Scott, 1898.

The Mackenzie River Basin: Evidence of Mr. Elihu Stewart before the Select Standing Committee on Agriculture and Colonization, 1906-7. Prepared by Elihu Stewart. Ottawa: King's Printer, 1907.

\section{Newspapers}

Boston Daily

Boston Daily Globe

Chicago Daily Tribune

Edmonton Bulletin

Los Angeles Times

New York Times

Toronto Mail 
Washington Post

Winnipeg Times

\section{Published Sources}

Abel, Kerry M. Drum Songs: Glimpses of Dene History. Montreal and Kingston: McGill-Queen's University Press, 2005.

Alcock, Frederick J. "Scow Brigade on the Athabaska." Canadian Geographical Journal 1932; 174.3 (1967): 92-99.

Alloula, Malek. The Colonial Harem. Minneapolis: University of Minnesota Press, 1986.

Anderson, Benedict. Imagined Communities: Reflections on the Origin and Spread of Nationalism. London: Verso, 1991.

Armstrong, Carol. Scenes in a Library: Reading the Photograph in the Book, 18431875. Cambridge, London: The MIT Press, 1998.

Babe, Robert E. Canadian Communication Thought: Ten Foundational Writers. Toronto: University of Toronto Press, 2000.

Baigrie, Brian S., Ed. Picturing Knowledge: Historical and Philosophical Problems Concerning the Use of Art in Science. Toronto: University of Toronto Press, 1996.

Baltzly, Benjamin. Benjamin Baltzly: Photographs \& Journal of an Expedition through British Columbia, 1871. Ed. Andrew Birrell. Toronto: Coach House Press, 1978.

Barthes, Roland. Camera Lucida. New York: Hill and Wang, 1981. Mythologies. New York: Hill and Wang, 1972.

Begg, Alexander. The Great North-West of Canada: A Paper Read at Conference, Indian and Colonial Exhibition, London, June 8th, 1886. London: H. Blacklock \& Co 1886.

Bell, Robert. The Geographical Distribution of the Forest Trees of Canada. Ottawa: Gazette Printing Company, 1882.

- The 'Medicine-Man'; or, Indian and Eskimo Notions of Medicine, a Paper Presented at the Bathurst and Rideau Medical Association: Montreal: Gazette Printing Company, 1886. 
Benjamin, Walter. "The Work of Art in the Age of Mechanical Reproduction." Illuminations. Ed. Hannah Arendt. Glasgow: William Collins Sons \& Co Ltd, 1979.

Bennett, Tony. The Birth of the Museum: History, Theory, Politics. London and New York: Routledge, 1995.

Berger, Carl. The Sense of Power: Studies in the Ideas of Canadian Imperialism, 18671914. Toronto: University of Toronto Press, 1970.

—. "The True North Strong and Free." Canadian Culture: An Introductory Reader. Ed. Elspeth Cameron. Toronto: Canadian Scholars' Press, 1997.

- The Writing of Canadian History: Aspects of English-Canadian Historical Writing since 1900. Second Edition. Toronto: University of Toronto Press, 1986.

Berger, John. Ways of Seeing. London: British Broadcasting Corporation, 1972.

Boorne, W.H. "Among the Savages of the Far West." The Canadian Photographic Journal 2.11-12 (1893): 372-373.

Brown, Callum G. Postmodernism for Historians. Harlow: Pearson Education Ltd., 2005.

Burgin, Victor. Thinking Photography. London: MacMillan, 1982.

Burnett, Kristin. "Aboriginal and White Women in the Publications of John Maclean, Egerton Ryerson Young, and John McDougall." Unsettled Pasts: Reconceiving the West through Women's History. Ed. Sarah Carter, Lesley Erickson, Patricia Roome and Char Smith. Calgary: University of Calgary Press, 2005.

Burpee, Lawrence Johnston. The Search for the Western Sea: The Story of the Exploration of North-Western America. Toronto: The Musson Book Company, Ltd, 1908.

- The Search for the Western Sea: The Story of the Exploration of North-Western America. Volume I \& II. 1908; Toronto: The MacMillan Company of Canada, Ltd, at St. Martin's House, 1935.

Buxton, William J. "Time, Space and the Place of Universities in Western Civilization: Harold Innis' Plea." International Journal of Canadian Studies 15 (1997): 37-48.

Cameron, Agnes Deans. The New North: An Account of a Woman's 1908 Journey through Canada to the Arctic. Ed. David Richeson. 1909; Saskatoon: Western Producer Prairie Books, 1986. 
- The New North: Being Some Account of a Woman's Journey through Canada to the Arctic. With Many Illustrations from Photographs by the Author. New York and London: D. Appleton and Company, 1910.

Cardinal, Louis. "Cartographic and Hydrographic Surveys in Canada: The Sum of the Parts." The Archivist 19.3 (1992): 8-10.

Careless, J. M. S. Frontier and Metropolis: Regions, Cities, and Identities in Canada before 1914. Toronto: University of Toronto Press, 1989.

Carter, Paul. The Road to Botany Bay: An Exploration of Landscape and History. New York: Alfred A Knopf, 1988.

Cashman, A.W. The Edmonton Story: The Life and Times of Edmonton, Alberta. 1956 Reprint ed. Edmonton: The Institute of Applied Art, Ltd., 1960.

Cavell, Janice. "The Second Frontier: The North in English-Canadian Historical Writing." Canadian Historical Review 83.3 (2002): 364-384.

Chalmers, John W., Ed. The Land of Peter Pond. Edmonton: Boreal Institute for Northern Studies, 1974.

Chastko, Paul. Developing Alberta's Oil Sands: From Karl Clark to Kyoto. Calgary: University of Calgary Press, 2004.

Childs, Elizabeth C. "The Colonial Lens: Gauguin, Primitivism, and Photography in the Fin De Siècle." Antimodernism and Artistic Experience: Policing the Boundaries of Modernity. Ed. Lynda Jessup. Toronto: University of Toronto Press, 2001.

Clayton, Daniel. Islands of Truth: The Imperial Fashioning of Vancouver Island. Vancouver: UBC Press, 2000.

Clifford, James. "On Collecting Art and Culture." The Visual Culture Reader. Ed. Nicholas Mirzoeff. London and New York: Routledge, 1998.

- The Predicament of Culture: Twentieth-Century Ethnography, Literature, and Art. Cambridge: Harvard University Press, 1988.

Coates, Kenneth, and Kerry M. Abel. Northern Visions: New Perspectives on the North in Canadian History. Peterborough: Broadview Press, 2001.

Coates, Kenneth, and William R. Morrison. The Forgotten North: A History of Canada's Provincial Norths. Toronto: J. Lorimer, 1992.

- The Historiography of the Provincial Norths. Thunder Bay: Centre for Northern Studies, Lakehead University, 1996. 
—. Interpreting Canada's North: Selected Readings. Toronto: Copp Clark Pitman, 1989.

- Land of the Midnight Sun: A History of the Yukon. 2nd ed. Montreal and Kingston: McGill-Queen's University Press, 2005.

- "Winter and the Shaping of Northern History: Reflections from the Canadian North." Northern Visions: New Perspectives on the North in Canadian History. Ed. Kerry M Abel and Kenneth Coates. Peterborough: Broadview Press, 2001.

Coates, Kenneth, William R. Morrison, and Morris Zaslow. For Purposes of Dominion: Essays in Honour of Morris Zaslow. North York, Ont.: Captus Press, 1989.

Cody, H. A. An Apostle of the North: Memoirs of the Right Reverend William Carpenter Bompas, D.D. New York: E.P. Dutton, 1908.

Cook, Ramsay. "Regionalism Unmasked." Acadiensis 13 (1983): 137-142.

Corbey, Raymond. "Ethnographic Showcases, 1870-1930." Cultural Anthropology 8.3 (1993): 338-369.

Crary, Jonathan. Techniques of the Observer: On Vision and Modernity in the Nineteenth Century. Cambridge, Mass: MIT Press, 1990.

Creighton, Donald. The Commercial Empire of the St. Lawrence. 1937; Toronto: MacMillan, 1956.

Cronon, William. Changes in the Land: Indians, Colonists and the Ecology of New England. New York: Hill and Wang, 1983.

- Nature's Metropolis: Chicago and the Great West. New York and London: W.W. Norton \& Company, 1991.

Cruikshank, Julie. Do Glaciers Listen? Local Knowledge, Colonial Encounters, and Social Imagination. Seattle and Vancouver: University of Washington Press, UBC Press, 2005.

Dawson, G.M. The Journals of George M. Dawson : British Columbia, 1875-1878. Ed. Douglas Cole and Bradley Lockner. Vancouver: UBC Press, 1989.

- On Some of the Larger Unexplored Regions of Canada. A Paper Presented at the Ottawa Field-Naturalists' Association. Ottawa: Ottawa Naturalist, 1890.

Dick, Lyle. Muskox Land: Ellesmere Island in the Age of Contact. Calgary: University of Calgary Press, 2001. 
Dippie, Brian W. "Photographic Allegories and Indian Destiny." Images of the Indian: Portrayals of Native People. Ed. Joe Sawchuk. Brandon: Bearpaw Publishing, 1995.

Douglas, George M. Lands Forlorn: A Story of an Expedition to Hearne's Coppermine River; with 180 Photographs by the Author, and Maps. New York and London: The Knickerbocker Press, 1914.

Dunaway, Finis. "Hunting with the Camera: Nature Photography, Manliness, and Modern Memory, 1890 - 1930." Journal of American Studies 34.2 (2000): 207 230 .

Duncan, James S., and Derek Gregory, Eds. Writes of Passage: Reading Travel Writing. London and New York: Routledge, 1999.

Edwards, Elizabeth. Raw Histories: Photographs, Anthropology and Museums. Oxford and New York: Berg, 2001.

Evenden, Matthew D. Fish Versus Power: An Environmental History of the Fraser River. Cambridge and New York: Cambridge University Press, 2004.

—. "The Northern Vision of Harold Innis." Journal of Canadian Studies 34.3 (1999): 1621-1186.

F.C.S.C. "Photography and the Indian." The Canadian Photographic Journal 4.8 (1895): 218-220.

Ferguson, Barry Glen. Athabasca Oil Sands: Northern Resource Exploration, 18751951. Edmonton: Alberta Culture, Canadian Plains Research Centre, 1985.

Forestell, Nancy. "Women, Gender, and the Provincial North." Northern Visions: New Perspectives on the North in Canadian History. Ed. Kerry M Abel and Kenneth Coates. Peterborough: Broadview Press, 2001.

Foster, Jeremy. "Capturing and Losing the 'Lie of the Land': Railway Photography and Colonial Nationalism in Early Twentieth-Century South Africa." Picturing Place: Photography and the Geographical Imagination. Ed. Joan M. Schwartz and James R. Ryan. London: I.B. Tauris, 2003.

Foster, John E. "The Métis: The People and the Term." Prairie Forum 3.1 (1978): 7990.

Fraser, H.C. "Photo." Canadian Journal of Photography 1.2 (1875): 17.

Friedrich, Otto. "The Idea of North." Canadian Culture: An Introductory Reader. Ed. Elspeth Cameron. Toronto: Canadian Scholars' Press, 1997. 
Friesen, Gerald. Citizens and Nation; an Essay on History, Communication and Canada. Toronto: University of Toronto Press., 1999.

- The West: Regional Debate, National Ambitions, Global Age. Toronto: Penguin Books Ltd, 1999.

Fumoleau, Rene. As Long as This Land Shall Last: A History of Treaty 8 and Treaty 11, 1870-1939. Toronto: McClelland and Stewart, 1973.

Garrett, Graham. "The Mirror of Nature: Early Daguerreotype Photography in Canada." The Beaver 75.6 (1995): 11-18.

Geller, Peter G. "'Hudson's Bay Company Indians': Images of Native People and the Red River Pageant, 1920." Dressing in Feathers: The Construction of the Indian in American Popular Culture. Ed. S. Elizabeth Bird. Boulder: Westview Press, 1996.

- Northern Exposures: Photographing and Filming the Canadian North, 1920-45. Vancouver: UBC Press, 2004.

Gilson, George. "Kodaks at the World's Fair." The Canadian Photographic Journal 3.9 (1892): 272.

Grace, Sherill E. Canada and the Idea of North. Montreal and Kingston: McGillQueen's University Press, 2001.

Green-Lewis, Jennifer. Framing the Victorians: Photography and the Culture of Realism. Ithaca and London: Cornell University Press, 1996.

Greenhill, Ralph, and Andrew Birrell. Canadian Photography, 1839-1920. Toronto: Coach House Press, 1979.

Greenwell, Kim. "Picturing 'Civilization': Missionary Narratives and the Marigins of Mimicry." BC Studies 135 (2002): 3-45.

Gregory, Derek. "Edward Said's Imaginative Geographies." Thinking Space. Ed. Mike Crang and Nigel Thrift. London and New York: Routledge, 2000.

. "Emperors of the Gaze: Photographic Practices and Productions of Space in Egypt, 1839-1914." Picturing Place: Photography and the Geographical Imagination. Ed. Joan M. Schwartz and James R. Ryan. London: I.B. Tauris, 2003.

—_. Geographical Imaginations. Cambridge, MA: Blackwell, 1994.

- "Scripting Egypt: Orientalism and the Cultures of Travel." Writes of Passage: Reading Travel Writing. Ed. James S. Duncan and Derek Gregory. London and New York: Routledge, 1999. 
Hadley, Margery Tanner. "Photography, Tourism and the C.P.R.: Western Canada, 1884-1914." Essays on the Historical Geography of the Canadian West: Regional Perspectives on the Settlement Process. Ed. L.A. Rosenvall and S.M. Evans. Calgary: Department of Geography, University of Calgary, 1987.

Hallett, Brian. "Map Making at the Geological Survey of Canada." The Archivist 19.3 (1992): 5-7.

Hanbury, David T. "A Journey from Chesterfield Inlet to Great Slave Lake, 1898-9." s.n.? $76.1(1900)$.

Harley, J.B. The New Nature of Maps: Essays in the History of Cartography. Ed. Paul Laxton. Baltimore: The John Hopkins University Press, 2001.

Harris, R. Cole. Making Native Space: Colonialism, Resistance, and Reserves in British Columbia. Vancouver, B.C.: University of British Columbia Press, 2002.

- The Resettlement of British Columbia: Essays on Colonialism and Geographical Change. Vancouver: UBC Press., 1997.

Harvey, David. The Condition of Postmodernity: An Enquiry into the Origins of Cultural Change. Cambridge, MA: Blackwell, 1990.

Hoelscher, Steven. "The Photographic Construction of Tourist Space in Victorian America." Geographical Review 88.4 (1998): 548-570.

_. "Viewing Indians: Native Encounters with Power, Tourism, and the Camera in the Wisconsin Dells, 1866-1907." American Indian Culture and Research Journal 27.4 (2003): 1-51.

Huhndorf, Shari M. Going Native: Indians in the American Cultural Imagination. Ithaca and London: Cornell University Press, 2001.

Hunt, Lynn. "Introduction: History, Culture, and Text." The New Cultural History. Ed. Lynn Hunt. Berkley: University of California Press, 1989.

Huyda, Richard J. Camera in the Interior; the Assiniboine and Saskatchewan Exploring Expedition. Toronto: Coach House, 1975.

Innis, Harold A. The Bias of Communication. 1951; Toronto: University of Toronto Press, 1991.

- The Fur Trade in Canada: An Introduction to Canadian Economic History. New Haven: Yale University Press, 1930.

- The Fur Trade in Canada: An Introduction to Canadian Economic History. Revised Edition. 1930; Toronto: University of Toronto Press, 1973. 
Ironside, R. G., Patricia Alice McCormack, and Canadian Circumpolar Institute. The Uncovered Past: Roots of Northern Alberta Societies. Edmonton: Canadian Circumpolar Institute, 1993.

Jasen, Patricia. Wild Things: Nature, Culture, and Tourism in Ontario 1790-1914. Toronto: University of Toronto Press, 1995.

Jessup, Lynda, Ed. Antimodernism and the Artistic Experience: Policing the Boundaries of Modernity. Toronto: University of Toronto Press, 2001.

Jones-Imhotep, Edward. "Nature, Technology, and Nation." Journal of Canadian Studies 38.3 (2004): 5-36.

Kasson, Joy. "Staking a Claim to History." The Nineteenth Century Visual Culture Reader. Ed. Vanessa R. Schwartz and Jeannene M. Przyblyski. London and New York: Routledge, 2005.

King, J.C.H., and Henrietta Lidchi, Eds. Imaging the Arctic. Seattle and Vancouver: University of Washington Press, UBC Press, 1998.

Krech, Shepard. The Ecological Indian: Myth and History. New York: W.W. Norton \& Company, 1999.

La Roche, Frank. En Route to the Klondike: Chilkoot Pass and Skaguay Trial. Chicago: Press of the Henry O. Shepard Co., 1897.

Lahser, Otto. Backdoor to the Yukon: Diary by Otto Lahser. Ed. Carl Lahser. San Antonio: Pretense Press, 1996.

Lalvani, Suren. Photography and the Production of Modern Bodies. New York: SUNY Press, 1996.

Langford, Martha. Suspended Conversations: The Afterlife of Memory in Photographic Albums. Montreal and Kingston: McGill-Queen's University Press, 2001.

Laut, Agnes C. Heralds of Empire; Being the Story of One Ramsay Stanhope. Toronto W. Briggs, 1902.

- Lords of the North. Toronto: W. Briggs, 1900.

- Pathfinders of the West: Being the Thrilling Story of the Adventures of the Men Who Discovered the Great Northwest. New York: The MacMillan Company, 1904.

- The Story of the Trapper. Toronto: W. Briggs, 1902.

_. "The Twentieth Century Is Canada's: The Romantic Story of a People Just Discovering Their Own Country." World's Work 15 (1907): 8499-8517. 
- Vikings of the Pacific; the Adventures of the Explorers Who Came from the West, Eastward; Bering, the Dane; the Outlaw Hunters of Russia; Benyowsky, the Polish Pirate; Cook and Vancouver, the English Navigators; Gray of Boston, the Discoverer of the Columbia; Drake, Ledyard, and Other Soldiers of Fortune on the West Coast of America. New York and London: The Macmillan Company, 1905.

Laut, Agnes C., and Joseph Gerald Hagey. The 'Adventurers of England' on Hudson Bay: A Chronicle of the Fur Trade in the North. Toronto: Glasgow and Brook, 1914.

- Pioneers of the Pacific Coast: A Chronicle of Sea Rovers and Fur Hunters. Toronto: Glasgow and Brook, 1915.

Lawson, A.C. "Out of Beaten Paths." University of California Chronicle s.v. (1926): 6162.

Lears, T.J. Jackson. No Place of Grace: Antimodernism and the Transformation of American Culture 1880-1920. New York: Pantheon Books, 1981.

Legge, Valerie. "Heralds of Empire: Liminal Heroes and Visionary Fugitives." International Journal of Canadian Studies 15 (1997): 135-152.

Leonard, David W. "Charles Mair and the Settlement of 1899." Through the Mackenzie Basin: An Account of the Signing of Treaty No. 8 and the Script Commission, 1899. Ed. David W. Leonard. Edmonton: University of Alberta Press, Edmonton \& District Historical Society, 1999.

Londe, Albert. "La photographie dans les Voyages D'exploration et les Missions scientifiques." Association pour l'avancement des sciences (1893): 89-90.

Loo, Tina. States of Nature: Conserving Canada's Wildlife in the Twentieth Century. Vancouver: UBC Press, 2006.

Lyman, Christopher M. The Vanishing Race and Other Illusions: Photographs of Indians by Edward S. Curtis. New York: Pantheon Books, Smithsonian Institution, 1982.

MacFarlane, Roderick. Notes on Mammals Collected and Observed in the Northern Mackenzie River District, Northwest Territories of Canada, with Remarks on Explorers and Explorations of the Far North. Washington: Government Printing Office, 1905.

- "Notes on the Mammals and Birds of Northern Canada." Through the Mackenzie Basin: A Narrative of the Athabasca and Peace River Treaty Expedition. Ed. Toronto: William Briggs, 1908. 
MacGregor, J.G. Edmonton Trader: The Story of John A. McDougall. Toronto: McClelland and Stewart Limited, 1963.

- Paddle Wheels to Bucket-Wheels on the Athabasca. Toronto: McClelland and Stewart Limited, 1974.

Macoun, John. Autobiography of John Macoun, M.A., Canadian Explorer and Naturalist. Ottawa: Field Naturalists' Club, 1922.

Mair, Charles. Through the Mackenzie Basin: A Narrative of the Athabasca and Peace River Treaty Expedition of 1899. Toronto: William Briggs, 1908.

- Through the Mackenzie Basin: An Account of the Signing of Treaty No. 8 and the Script Commission, 1899. 1908; Edmonton: The University of Alberta Press, 1999.

Manning, Erin. Ephemeral Territories: Representing Nation, Home, and Identity in Canada. Minneapolis and London: University of Minnesota Press, 2003.

Marvin, Carolyn. "Dazzling the Multitude." Imagining Tomorrow: History, Technology and the American Future. Ed. J.J. Corn. Cambridge, Mass.: MIT Press, 1986.

Mathers, C.W. The Far North: A Souvenir from the North. Edmonton: C.W. Mathers, Minister of Agriculture, 1901.

—_. "A Trip to the Arctic Circle." The Farmer's Advocate 13.21 (1903): 1212.

—. "A Trip to the Arctic Circle." Alberta Historical Review 20.4 (1972): 6-16.

McClintock, Anne. Imperial Leather: Race, Gender and Sexuality in the Colonial Conquest. London and New York: Routledge, 1995.

McCormack, Patricia A., and R. Geoffrey Ironside, Eds. Proceedings of the Fort Chipewyan and Fort Vermilion Bicentennial Conference, September 23-25, 1988. Edmonton: Boreal Institute for Northern Studies, 1999.

- The Uncovered Past: Roots of Northern Alberta Societies. Edmonton: Canadian Circumpolar Institute, 1993.

McDougall, John. Saddle, Sled and Snowshoe: Pioneering on the Saskatchewan in the Sixties. Toronto: W. Briggs, 1896.

McKay, Ian, Ed. The Challenge of Modernity: A Reader on Post-Confederation Canada. Toronto: McGraw-Hill Ryerson Ltd., 1992.

-The Quest of the Folk: Antimodernism and Cultural Selection in TwentiethCentury Nova Scotia. Montreal and Kingston: McGill-Queen's University Pres, 1994. 
McLean, W.J. Notes and Observations of Travels on the Athabasca and Slave Lake Regions in 1899., The Historical and Scientific Society of Manitoba: Transaction 58. Winnipeg: Manitoba Free Press Company, 1901.

Mitchell, Timothy. "Orientalism and the Exhibitionary Order." The Visual Culture Reader. Ed. Nicholas Mirzoeff. London and New York: Routledge, 1998.

_- Ed. Questions of Modernity. Minneapolis and London: University of Minnesota Press, 2000.

Mitchell, W.J.T. "Imperial Landscape." Landscape and Power. Ed. W.J.T. Mitchell. Chicago and London: The University of Chicago Press, 1994.

- Ed. The Language of Images. Chicago and London: The University of Chicago Press, 1980.

- Picture Theory. Chicago: The University of Chicago Press, 1994.

Moberly, Henry John, and William Bleasdell Cameron. When Fur Was King. New York: Dutton, 1929.

Morrison, William R., Morris Zaslow, and Kenneth Coates. For Purposes of Dominion: Essays in Honour of Morris Zaslow. North York, Ont.: Captus Press, 1989.

Murton, James. "What J.W. Clark Saw in British Columbia, or, Nature and the Machine: A Photo Essay." BC Studies.142/143 (2004): 129-152.

Ogilvie, William. Down the Yukon and up the Mackenzie: 3,200 Miles by Foot and Paddle. Toronto: Toronto Publishing Company, 1893.

—. "The Freezing of Northern Rivers Dances in the Far North." [S.l. 1894.

Oliver, Frank. "To the Klondike - the All-Canadian Route." The Nor'-West Farmer 16.22 (1897): 453-459.

Orvell, Miles. The Real Thing: Imitation and Authenticity in American Culture, 1880 1940. Chapel Hill and London: The University of North Carolina Press, 1989.

Osborne, Brian S. "Constructing the State, Managing the Corporation, Transforming the Individual: Photography, Immigration, and the Canadian National Railways, 1925-30." Picturing Place: Photography and the Geographical Imagination. Ed. Joan M. Schwartz and James R. Ryan. London: I.B. Tauris, 2003.

Owram, Douglas, Ed. The Formation of Alberta: A Documentary History. Calgary: Alberta Records Publication Board: Historical Society of Alberta, 1979. 
- Promise of Eden: The Canadian Expansionist Movement and the Idea of the West, 1856-1900. Toronto: University of Toronto Press, 1980.

O'Leary, Daniel. "Environmentalism, Hermeneutics, and Canadian Imperialism in Agnes Deans Cameron's the New North." This Elusive Land: Women and the Canadian Environment. Ed. Melody Hessing, Rebecca Raglon and Catriona Sandilands. Vancouver: UBC Press, 2004.

Owram, Douglas, and R. G. Moyles. Imperial Dreams and Colonial Realities: British Views of Canada, 1880-1914. Toronto: University of Toronto Press, 1988.

Perry, Adele. "From 'the Hot-Bed of Vice' to the 'Good and Well-Ordered Christian Home': First Nations Housing and Reform in Nineteenth Century British Columbia." Ethnohistory 50.4 (2003): 587-610.

- On the Edge of Empire: Race, Gender and the Making of British Columbia, 1849-1871. Toronto: University of Toronto Press, 2001.

Peterson, Jacqueline, and Jennifer S.H. Brown, Eds. The New Peoples: Being and Becoming Métis in North America. Winnipeg: The University of Manitoba Press, 1985.

Petitot, Emile. Among the Chiglit Eskimos. Paris, Edmonton: E. Plon, Nourrit et Cie; Boreal Institute for Northern Studies, 1887; 1981.

- Among the Chiglit Eskimos. 1881; Paris and Edmonton: E. Plon, Nourrit et Cie, Boreal Institute for Northern Studies, 1981.

- "On the Athabaska District of the Canadian North-West Territory." London: Royal Geographical Society,, 1883.

Petitot, Emile, John S. Moir, Paul Laverdure, and Jacqueline Moir. Travels around Great Slave and Great Bear Lakes, 1862-1882. 1891; Toronto: Champlain Society, 2005.

Phillips, Richard. Mapping Men and Empire: A Geography of Adventure. London and New York: Routledge, 1997.

Pike, Warburton. The Barren Ground of Northern Canada. 1892; New York: E.P. Dutton \& Company, 1917.

- The Barren Ground of Northern Canada. London and New York: Macmillan, 1892.

Poulter, Gillian. "Montreal and Its Environs: Imagining a National Landscape, C. 18671885." Journal of Canadian Studies 38.3 (2004): 69-100. 
Pratt, Mary Louise. Imperial Eyes: Travel Writing and Transculturation. London and New York: Routledge, 1992.

Raibmon, Paige. Authentic Indians: Episodes of Encounter from the Late NineteenthCentury Northwest Coast. Durham: Duke University Press, 2005.

- "Living on Display: Colonial Visions of Aboriginal Domestic Spaces." $B C$ Studies.140 (2003): 69-89.

Ray, Arthur J. The Canadian Fur Trade in the Industrial Age. Toronto: University of Toronto Press, 1990.

- Indians in the Fur Trade: Their Role as Trappers, Hunters, and Middlemen in the Lands Southwest of Hudson Bay, 1660-1870. Toronto and Buffalo: University of Toronto Press, 1974.

Robertson, Peter, and Andrew Rodger. "Photography and the Geological Survey of Canada." The Archivist 19.3 (1992): 11-13.

Roe, Frank Gilbert. "Getting the Know-How": Homesteading and Railroading in Early Alberta. Ed. J.P. Regan. Edmonton: NeWest Press, 1982.

Rosaldo, Renato. Culture \& Truth: The Remaking of Social Analysis. Boston: Beacon Press, 1989.

Ross, Eric. "East Winnipeg, Muskrat and English River Countries, and the Barren Grounds." Peoples, Places, Patterns, Processes: Geographical Perspectives on the Canadian Past. Ed. Graeme Wynn. Toronto: Copp Clark Pitman Ltd., 1990.

Roy, Wendy. Maps of Difference: Canada, Women, and Travel. Montreal and Kingston: McGill-Queen's University Press, 2005.

Russell, Frank. "Athabascan Myths." The Journal of American Folklore 13.48 (1900): 11-18.

- Explorations in the Far North: Being the Report of an Expedition under the Auspices of the University of Iowa During the Years 1892, '93, and '94. Iowa City: University of Iowa, 1898.

Ryan, James R. Picturing Empire: Photography and the Visualization of the British Empire. Chicago: University of Chicago Press, 1997.

Said, Edward. Culture and Imperialism. New York: Alfred A. Knopf, 1993.

- Orientalism. New York: Vintage Books, 1979.

Samuel, Raphael. Theatres of Memory: Past and Present in Contemporary Cultures. London and New York: Verso, 1994. 
Samuels, Maurice. "The Illustrated History Book: History between Word and Image." The Nineteenth Century Visual Culture Reader. Ed. Vanessa R. Schwartz and Jeannene M. Przyblyski. London and New York: Routledge, 2004.

Sandweiss, Martha A. Print the Legend: Photography and the American West. New Haven and London: Yale University Press, 2002.

. "Undecisive Moments: The Narrative Tradition in Western Photography." Photography in Nineteenth-Century America. Ed. Martha A Sandweiss. Fort Worth and New York: Amon Carter Museum, H.N. Abrams, 1991.

Schloss, Carol. In Visible Light: Photography and the American Writer, 1840-1940. New York: Oxford University Press, 1987.

Schwartz, Joan M. "Coming to Terms with Photographs: Descriptive Standards, Linguistic 'Othering' and the Margins of Archivy." Archivaria 54 (2002): 142171.

- "The Geography Lesson: Photographs and the Construction of Imaginative Geographies." Journal of Historical Geography 22.1 (1996): 16-45.

—_. "More Than 'Competent Description of an Intractably Empty Landscape': A Strategy for Critical Engagement with Historical Photographs." Historical Geography 31 (2003): 105-130.

. "Photographs from the Edge of Empire." Cultural Geography in Practice. Ed. Alison Blunt, Prys Gruffudd, John May, Miles Osborn and David Pinde. New York: Oxford University Press, Inc, 2003.

—_. "Photography at the Speed of Life." Queen's Quarterly 108.3 (2001): 431-436.

_. "'Records of Simple Truth and Precision': Photography, Archives, and the Illusion of Control." Archivaria 50 (2000): 1-40.

Schwartz, Joan M., and James R. Ryan, Eds. Picturing Place: Photography and the Geographical Imagination. London: I.B. Tauris, 2003.

Sekula, Allan. "Reading an Archive." Blasted Allegories: An Anthology of Writings by Contemporary Artists. Ed. Brian Wallis. New York: New Museum of Contemporary Art, 1987.

—. "The Traffic in Images." Art Journal 41.1 (1981): 15-25.

Sekula, Allan, John O'Brian, and Gary Dufour. Geography Lesson: Canadian Notes. Vancouver and Cambridge: Vancouver Art Gallery, MIT Press, 1997. 
Seton, Ernest Thompson. The Arctic Prairies: A Canoe Journey of 2,000 Miles in Search of the Caribou; Being the Account of a Voyage to the Region North of Aylmer Lake. Toronto: William Briggs, 1911.

Silverman, Eliane Leslau. The Last Best West: Women on the Alberta Frontier, 18801930. Calgary: Fifth House Publishers, 1998.

Silversides, Brock V. "Charles Wesley Mathers." History of Photography 14.4 (1990): 327-348.

—. "Charles Wesley Mathers." C.W. Mathers' Vision. Ed. Brock V. Silversides and Provincial Archives of Alberta. Edmonton: Provincial Archives of Alberta, 1989.

- The Face Pullers: Photographing Native Canadians, 1871-1939. Saskatoon: Fifth House Publishers, 1994.

Somerset, H. Somers. The Land of the Muskeg. London: W. Heinemann, 1895.

Spencer, P.L. "The Camera in the Mission Field." The Canadian Photographic Journal 3.5 (1894): 206-208.

- "The Camera in the Mission Field: Algoma and the West." The Canadian Photographic Journal 4.5 (1895): 123.

. "The Camera in the Mission Field: British Columbia." The Canadian Photographic Journal 4.6 (1895): 147-149.

—. "The Camera in the Mission Field: The North West." The Canadian Photographic Journal 4.2 (1895): 36, 68-70.

Stefansson, Vilhjalmur. The Northward Course of Empire. New York: MacMillan, 1922.

Stewart, Elihu. Down the Mackenzie and up the Yukon in 1906. Toronto: Bell and Cockburn, 1913.

Stewart, Susan. On Longing: Narratives of the Miniature, the Gigantic, the Souvenir, the Collection. Baltimore: Johns Hopkins University Press, 1984.

Stoler, Ann Laura. Carnal Knowledge and Imperial Power: Race and the Intimate in Colonial Rule. Berkeley: University of California Press, 2002.

- Race and the Education of Desire: Foucault's History of Sexuality and the Colonial Order of Things. Durham: Duke University Press, 1995.

Tagg, John. The Burden of Representation: Essays on Photographies and Histories. Amherst: The University of Massachusetts Press, 1988. 
Thomas, Lewis G., David H. Breen, John A. Eagle, John E. Foster, and Roderick C. MacLeod, Eds. The Prairie West to 1905 : A Canadian Sourcebook. Toronto: Oxford University Press, 1975.

Trachtenberg, Alan. Reading American Photographs: Images as History, Mathew Brady to Walker Evans. New York: Hill and Wang, 1989.

- Shades of Hiawatha: Staging Indians, Making Americans 1880-1930. New York: Hill and Wang, 2004.

Triggs, Stanley G. "Alexander Henderson: Nineteenth Century Landscape Photographer." Archivaria 5 (1977-78): 45-59.

Tuttle, Charles R. Our North Land: Being a Full Account of the Canadian North-West and Hudson's Bay Route, Together with a Narrative of the Experiences of the Hudson's Bay Expedition of 1884, Including a Description of the Climate, Resources, and the Characteristics of the Native Inhabitants between the 50th Parallel and the Arctic Circle. Toronto: C. Blackett Robinson, 1885.

Tyrrell, J.W. Across the Sub-Arctics of Canada: A Journey of 3,200 Miles by Canoe and Snowshoe through the Barren Lands. Toronto: William Briggs, 1897.

Vibert, Elizabeth. Traders' Tales: Narratives of Cultural Encounters in the Columbia Plateau, 1807-1846. Norman: University of Oklahoma Press, 1997.

Wadland, John. Ernest Thompson Seton: Man in Nature and the Progressive Era, 18801915. New York: Arno Press, 1978.

—_. "Great Rivers, Small Boats: The Environment in Canadian Historical Culture." Changing Parks: The History, Future and Cultural Context of Parks and Heritage Landscapes. Ed. John Marsh and Bruce Hodgins. Toronto: Natural Heritage Press, 1998.

Waiser, Bill. "A Very Long Journey: Distance and Northern History." Northern Visions: New Perspectives on the North in Canadian History. Ed. Kerry M Abel and Kenneth Coates. Peterborough: Broadview Press, 2001.

Walden, Keith. Becoming Modern in Toronto: The Industrial Exhibition and the Shaping of a Late Victorian Culture. Toronto: University of Toronto Press, 1997.

Wetherell, Donald G., and Irene Kmet. Alberta's North: A History, 1890 to 1950. Edmonton, Alta.: Canadian Circumpolar Institute Press, University of Alberta Press, Alberta Community Development, 2000.

Whitney, Caspar. On Snow-Shoes to the Barren Grounds: Twenty-Eight Hundred Miles after Musk-Oxen and Woodbison. New York: Harper \& Brothers Publishers, 1896. 
Williams, Carol J. Framing the West: Race, Gender, and the Photographic Frontier in the Pacific Northwest. Oxford: Oxford University Press, 2003.

Williams, Megan Rowley. Through the Negative: The Photographic Image and the Written Word in Nineteenth-Century American Literature. London and New York: Routledge, 2003.

Wilson, Alexander. The Culture of Nature: North American Landscape from Disney to the Exxon Valdez. Toronto: Between the Lines, 1991.

Winship, Geo. B. "My First Flat-Boat Ride Down the Red River, and Incidents Connected Therewith." Canadian North-West Historical Society Publications: Chapters in the North-West History Prior to 1890: Related by Old Timers. Ed. The Canadian North-West Historical Society. Battleford: The Canadian NorthWest Historical Society, 1928.

Wonders, William C., Ed. Canada's Changing North. Toronto: McClelland and Stewart Limited, 1971.

Young, Egerton R., and Mark Guy Pearse. By Canoe and Dog-Train among the Cree and Salteaux Indians. New York,: Hunt, 1890.

Zaslow, Morris. The Opening of the Canadian North, 1870-1914, The Canadian Centenary Series. Toronto: McClelland and Stewart, 1971.

- Reading the Rocks: The Story of the Geological Survey of Canada, 1842-1972. Toronto and Ottawa: Macmillan Company of Canada, Department of Energy, Information Canada, 1975.

Zeller, Suzanne. Inventing Canada: Early Victorian Science and the Idea of a Transcontinental Nation. Toronto: University of Toronto Press, 1987.

\section{Unpublished Sources}

Beckwith, Laurie A. An Introduction to the Geological Survey of Canada Photographs at the National Archives of Canada. Unpublished: National Archives of Canada, 1999.

Bell, Robert. "The Athabasca-Mackenzie Basin." Paper presented at the Somerville Lecture, Hall of the Natural History Society, 1 March 1883.

—_. "Petroleum in the North West Territories." Paper presented at the Canadian Institute, Canadian Institute, n.d. 1883. 
Opp, James. "Photographs and Public Memory in Prairie Canada." Paper presented at the Collective Memory and the Uses of the Past: An Interdisciplinary Conference, University of East Anglia, Norwich, UK, 7 July 2006.

Schwartz, Joan M. "Agent of Sight, Site of Agency." Ph.D Dissertation, Department of Geography, Queen's University, Kingston, ON, 1998.

Shields, Maureen D. "Clifford Sifton, Frank Oliver and the Decline of Nativism in Alberta, 1896-1911." M.A. Thesis, Department of History, Carleton University, Ottawa, ON, 1990. 